MONOGRAPHIAE BOTANICAE

Vol. 83, 1998

\title{
JANUSZ NOWAK
}

\section{POROSTY BESKIDÓW WYSPOWEGO I ŻYWIECKIEGO, PASMA JALOWCA I MASYWU BABIEJ GÓRY}

THE LICHENS (LICHENIZED FUNGI) OCCURRENCE IN THE BESKID WYSPOWY, BESKID ŻYWIECKI AND PASMO JAŁOWCA RANGES, AND THE BABIA GÓRA MASSIF

\author{
Redaktor - Editor-in-Chief \\ Krystyna CZYŻEWSKA
}

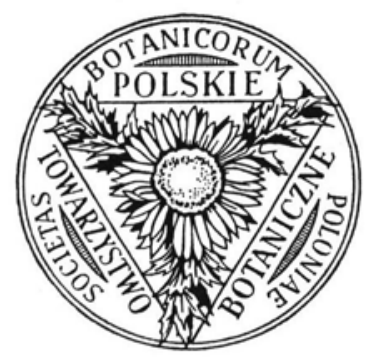


Wydano z pomocą finansową

Komitetu Badań Naukowych
Edited with financial support of the Polish Committee for Scientific Research (KBN)

\title{
REDAKCJA - EDITORIAL BOARD
}

Krystyna CzYžewska (Editor-in-Chief), Małgorzata Ruszkiewicz (Secretary)

\section{RADA REDAKCYJNA - EDITORIAL COUNCIL}

Stanisław Cié́LIŃSKI (Kielce), Krystyna CzYŻewSKa (Łódż), Władysław MatusZKiewicZ (Warszawa), Romuald Olaczek (Łódż) Przewodniczący - President, Hanna Piotrowska

(Gdańsk), Krzysztof RostaŃSKI (Katowice), Waldemar ŻUKowsKI (Poznań)

\author{
ADRES REDAKCJI - EDITORIAL OFFICE \\ Katedra Botaniki Chair of Botany \\ Uniwersytetu Łódzkiego University of Łódź \\ ul. Banacha 12/16 Banacha 12/16 \\ 90-237 Łódź PL-90-237 Łódź
}

OKŁADKĘ PROJEKTOWAŁ - COVER DESIGN BY

Zdzisław WALTER

INDEXED IN BIOLOGICAL ABSTRACTS AND ZOOLOGICAL RECORD

(c) Copyright by Polskie Towarzystwo Botaniczne, Warszawa 1998 


\section{SPIS TREŚCI}

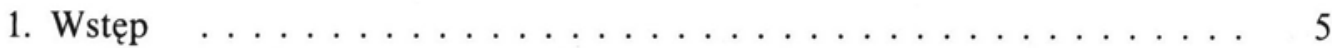

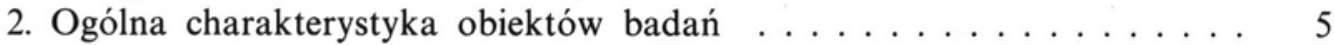

3. Różnorodność gatunkowa porostów .............. 6

4. Porosty Beskidu Wyspowego . . . . . . . . . . . . . . . . . 14

5. Porosty Beskidu Żywieckiego, Pasma Jałowca i Masywu Babiej Góry 55

6. Literatura . . . . . . . . . . . . . . . . . . . . . . . 131 


\section{ABSTRACT}

Janusz NowaK. The lichens (Lichenized Fungi) occurrence in the Beskid Wyspowy, Beskid Żywiecki and Pasmo Jalowca Ranges, and the Babia Góra Massif. Monogr. Bot., Vol. 83, 131 pp., 1998.

The work presents lichenological materials collected in the years 1964-1969 in the area of the Beskid Wyspowy, Beskid Żywiecki and Pasmo Jałowca Ranges and the Babia Góra Massif in the Western Carpathians. In the years 1996-1997 comparative studies of those mountain ranges were undertaken again. However, the author managed to reinvestigate the lichens of the Beskid Wyspowy Range only, he will probably not be able to continue the research in the other ranges. The check-list of the lichen species occurring there in the sixties, published now for the first time, can be the reference for the lichenologists who would carry out this project in the same way as the author referenced to the former investigations (STeIn 1872; Rehman 1879; Boberski 1886; MOtYKa 1934; Zshacke 1934; SuZA 1951).

In the Beskid Wyspowy Range 342 species of lichens were found, among them 112 epiphytic species, 30 epixylic species, 6 epibryophytic species, 55 epigeic species and 139 epilithic species were recorded. One species of lichenicolous fungus was also found Epilichen scabrosus.

In the Beskid Żywiecki and Pasmo Jałowca Ranges, and Babia Góra Massif 543 species of lichens occurred, among them 183 epiphytic species, 43 epixylic species, 21 epibryophytic species, 69 epigeic species and 194 epilithic species. The check-list includes also lichenicolous species: Carbonea vitellinaria, Chaenothecopsis consociata, Microcalicium arenarium, Sphinctrina turbinata, Stenocybe pullatula. In the Babia Góra Massif 27 species previously published from there were not found again: Catolechia wahlenbergii, Cliostomum corrugatum, Phaeographis dendritica, Polyblastia cupularis, P. sendtneri, Solorina crocea, Sticta sylvatica (comp. STEIN 1872), Ramalina calicaris (REHMAN 1879), Usnea florida, $U$. longissima, U. scrobiculata (MоTYKA 1934), Polyblastia pallescens (ZsCHACKE 1934), Arthrorhaphis alpina, Cladonia amaurocrea, C. bellidiflora, C. cyanipes, C. macrophylla, Evernia divaricata, Hypotrachyna sinuosa, Mycobilimbia berengeriana, Nephroma laevigatum, Peltigera malacea, P. venosa, Solorina saccata, Sphaerophorus fragilis, Sporastatia polyspora, Thamnolia vermicularis (comp. SUZA 1951).

Key words: Lichens; the Beskid Wyspowy, Beskid Żywiecki and Pasmo Jalowca Ranges, the Babia Góra Massif; the Western Carpathian; S Poland. 


\section{WSTĘP}

W latach 1964-1969 prowadzono badania pionowego i poziomego rozmieszczenia porostów w Beskidach Zachodnich, w podokręgu śląsko-babiogórskim (NowAK 1972). Zebrane wówczas ogromne materiały lichenologiczne zostały opublikowane częściowo (NowAK 1965, 1967, 1968). Materiały zielnikowe zbierano tylko w przypadku bardziej interesujących taksonów oraz takich, których prawidłowe określenie $\mathrm{w}$ terenie było trudne lub niemożliwe. Pozostałe dane pochodzą z zapisków terenowych ze wszystkich stanowisk porostów. Publikowane i niepublikowane wyniki tych badań gromadzono w kartotece.

Uznano, że należy opublikować pozostałe materiały, tym bardziej że w ciągu ponad 30. lat zaszły tam poważne, niekorzystne zmiany we florze porostów. Obecnie należałoby powtórzyć badania, aby stwierdzić w jakim stopniu flora ta zubożała.

W latach 1996 i 1997 podjąlem ponownie zbieranie materialów w Beskidzie Makowskim i Wyspowym, ale prawdopodobnie nie będę $w$ stanie tej pracy dokończyć. Uważam, że moi następcy, którzy podejma temat, winni mieć punkt odniesienia do zebranych lub spisanych przeze mnie danych w latach 1964-1969, tak jak ja mialem odniesienie do starszych danych (STEIN 1872; REHMAN 1879; BOBERSKI 1886; MOTYKA 1934; ZSHACKE 1934 lub SUZA 1951). Tym motywuje celowość obecnej publikacji.

Materiały lichenologiczne zebrane w latach 1964-1969 są przechowywane w Herbarium porostów Instytutu Botaniki im. Władysława Szafera PAN w Krakowie (KRAM-L).

\section{OGÓLNA CHARAKTERYSTYKA OBIEKTÓW BADAŃ}

Beskid Wyspowy. Granice Beskidu Wyspowego są trudne do ścisłego określenia. Rozciąga się on od szosy Lubień - Skomielna Biała na zachodzie po dolinę Dunajca na wschodzie; z obszaru badań wyłączono górę Zębalową. Obejmuje góry: Luboń Wielki (1023 m n.p.m.), Szczebel (977 m), Lubogoszcz (967 m), Śnieżnicę (1007 m), Ćwilin (1071 m), Ogorzałą (806 m), Jasień (1052 m), Mogielicę (1170 m), Łopień (951 m). Do terenu badań włączono również, położone na północ od Lubogoszczy i rzeki Łososiny góry: Wierzbanowską Górę (714 m), Kostrzę (719 m), Kamionną $(801 \mathrm{~m})$, Stawiska (Łopusze $661 \mathrm{~m})$ i Kobyłę $(609 \mathrm{~m})$. Wszędzie tutaj góry są odosobnione i wyspowo wznoszące się, posiadają strome lub bardzo spadziste stoki oraz płaskie wierzchowiny. Poczynając od Limanowej zmieniają swój charakter na wyraźnie pasmowy. Najdłuższym jest pasmo Jaworza $(917 \mathrm{~m})$, położone na południe 
od rzeki Łososiny; również taki charakter posiadają pasma rozciągające się na wschód od Tokonia $(924 \mathrm{~m})$, Modynia $(1028 \mathrm{~m})$ poprzez Jasieńczyk (860 m) i Szkiełek (749 m). Najmniej interesujące są góry położone między nimi, mianowicie: Golców (752 m), Kuklacz (702 m), Łyżka (802 m), Pępówka (774 m) i Kamera (Piekło $652 \mathrm{~m}$ ). Od Gorców bardzo dobrze oddzielają Beskid Wyspowy doliny potoków Mszanki i Kamienicy.

Budowa geologiczna Beskidu Wyspowego jest typowa dla tego obszaru Karpat. Występują tu głównie warstwy magurskie, krośnieńskie i inoceramowe. Nie ma zbyt wielu naturalnych skał i gołoborzy. Te ostatnie najokazalej są reprezentowane na południowych stokach góry Luboń Wielki, gdzie w obrębie lasu znajdują się olbrzymie jego powierzchnie, będące jaszcze dzisiaj podłożem dla wielu porostów epilitycznych. Inne, już nie tak okazałe, znajdują się na górach Wierzbanowskiej, Kobylicy lub Turni blisko Kamienicy.

Beskid Żywiecki zwany niekiedy Wysokim, ze względu na kulminację Babiej Góry (1725 m n.p.m.) i Pilska (1520 m), stanowi najwyższą część Beskidów Zachodnich. Wchodzi on w skład podokręgu śląsko-babiogórskiego (por. NowAK 1972). W niniejszej pracy wydzielono w nim grupę Wielkiej Raczy [WR] (od Zwardonia do przełęczy Glinka), grupę Pilska [P] (od przełęczy Glinka do przełęczy Glinne), masyw Babiej Góry [BG] (od przełęczy Jałowieckiej do przełęczy Krowiarki) i pasmo Jałowieckie [J] (od przełęczy Jałowieckiej do doliny Skawy). Pasmo Policy zostało opublikowane wcześniej (NowAK 1967).

\section{RÓŻNORODNOŚĆ GATUNKOWA POROSTÓW}

Porosty naskalne. W Beskidzie Wyspowym rosną one najczęściej na stosach kamieni, które są usypywane z kamieni wyorywanych z pól i łąk oraz na luźnych murkach kamiennych, układanych na granicach tych pól. Mniej często występują na naturalnych skałach i skałkach nad potokami lub na osuwiskowych brzegach rzek. Niewiele jest tutaj utworów typowo skalnych, wieńczących na przykład wierzchołki gór, więcej jest ich w pozostałych pasmach. Zwykle są to utwory bezwęglanowe i tylko częściowo zawierają duże ilości węglanu wapnia, np. na górze Zamczysko (Białowodzka Góra) we wschodniej części pasma Jaworza. Trzydzieści lat temu flora porostów naskalnych była dość bogata. Gatunki osiedlały się na licznych stanowiskach, były dorodne i zdrowe.

$\mathrm{Na}$ bezwęglanowym podłożu skalnym w latach 60. występowały: Acarospora fuscata, A. heppi, A. insolata, A. umbilicata, A. veronensis, Amandinea punctata, Aspicilia caesiocinerea, A. cinerea, A. insolata, A. laevata, A. simoënsis, Baeomyces rufus, Buellia aethelea, B. leptocline, B. ocellata, Caloplaca flavovirescens, C. holocarpa (częściowo), Candelariella vitellina, Cystocoleus ebeneus, Diploschistes scruposus, Enterographa zonata, Immersaria athroocarpa, Lecanactis dilleniana, L. latebrarum, Lecanora campestris, L. cenisia, L. intricata, L. muralis, L. polytropa 
L. rupicola, L. soralifera, L. sulphurea, L. umbrina, Lecidea confluens, L. fuscoatra, L. lactea, L. lithophila, L. plana, Lecidella asema, L. carpathica, L. stigmatea (częściowo), L. viridans, Lepraria neglecta, Melanelia fuliginosa, Micarea sylvicola, Miriquidica leucophaea, Neofuscellia loxodes, Ochrolechia lactea, Opegrapha gyrocarpa, Pannaria leucophaea, Parmelia saxatilis (częściowo), Phaeophyscia sciastra, Physcia caesia (częściowo), Ph. dubia, Ph. wainioi, Polysporina lapponica, P. simplex, Porina guetheri, Porpidia crustulata, P. macrocarpa, P. speirea, P. tuberculosa, Protoparmelia badia, Psilolechia lucida, Rhizocarpon badioatrum, Rh. distinctum, Rh. geographicum, Rh. obscuratum, Rh. petraeum, Rh. polycarpum, Scoliciosporum umbrinum, Sterocaulon nanodes, Tephromela atra, Thelocarpon laureri (częściowo), Trapelia coarctata, T. obtegens, T. placodioides, Umbilicaria cylindrica, U. deusta, U. polyphylla, Xanthoparmelia conspersa.

$\mathrm{Z}$ tych gatunków wymarły lub prawdopodobnie wymierają następujące taksony: Aspicilia insolata, Buellia leptocline, B. ocellata, Cystocoleus ebeneus, Immersaria athroocarpa, Lecanactis dilleniana, Lecidea lactea, Lecidella asema. L. viridans, Miriquidica leucophaea, Pannaria leucophaea, Porina guentheri, Porpidia speirea (?), Stereocaulon nanodes, Umbilicarioa cylidrica, $U$. deusta $i U$. polyphylla. Liczne gatunki bardzo ograniczyły swoje rozprzestrzenienie; niektóre stały się nadzwyczaj rzadkie, np. Rhizocarpon geographicum.

Niektóre gatunki naskalne można zaliczyć do porostów wodnych, ponieważ żyją stale w środowisku wodnym lub w bardzo wilgotnym. Są to: Bacidina inundata, Collema auriforme, C. dichotomum, C. flaccidum, Porina chlorotica, Verrucaria anziana, $V$. aquatilis, $V$. denudata, $V$. funckii, $V$. guestphalica, $V$. laevata, $V$. rhethrophila, V. subhydrela, V. submauroides. Spomiędzy nich wyginęły już lub giną Collema dichotomum, Porina chlorotica $i$ Verrucaria rheuthrophila.

$\mathrm{Na}$ skałach bardzo zasobnych w węglan wapnia, np. we wschodniej części Beskidu Wyspowego (góra Zamczysko koło Białej Wody) trzydzieści lat temu spotykano bardzo wiele gatunków wapieniolubnych lub najczęściej rosnących na podłożu bogatym w ten składnik. Są to: Acarospora glaucocarpa, A. macrospora, Anema decipiens, Arthonia lapidicola, Aspicilia calcarea, A. contorta, A. farinosa, Caloplaca cirrochroa, C. citrina, C. dolomoticola, C. lactea, Catapyrenium lachneum, Catillaria lenticularis, Clauzadea monticola, Collema fuscovirens, C. polycarpon, Dermatocarpon miniatum, Diploschistes gypsaceus, Diplotomma epipolium, D. nivalis, Dirina stenhammari, Gyalecta jenensis, Lecania inundata, Lecanora crenulata, L. dispersa, Lepraria flavescens, Leproplaca xantholyta, Lobothalia radiosa, Peccania coralloides, Placynthium nigrum, Protoblastenia rupestris, Psorotichia schaereri, Sarcogyne regularis, Synalissa symphorea, Thelidium immersum, Toninia aromatica, Verrucaria fuscella, $V$. nigrescens i $V$. velana. Obecnie $\mathrm{z}$ tej grupy pozostały już jedynie gatunki pospolite; wyginęły prawie na pewno: Acarospora macrospora, Anema decipiens, Caloplaca cirrochroa, C. lactea, Catapyrenium lachneum, Collema polycarpon, Dermatocarpon miniatum, Peccania coralloides, Psorotichia schaereri, Synalissa symphorea, Toninia aromatica i Verrucaria velana.

$\mathrm{Na}$ betonie (słupki i bariery przydrożne, mury, mosty kolejowe i nad potokami) rosną, zwykle pospolicie: Caloplaca citrina, C. decipiens, Candelariella aurella, 
Lecanora albescens, L. dispersa, L. muralis, Phaeophyscia nigricans, Ph. orbicularis, Physcia adscendens, Ph. caesia, Xanthoria elegans i X. parietina.

W przypadku gatunków naskalnych nie ma zbyt wyraźnych różnic w składzie porostów Beskidów Wyspowego i Żywieckiego. Prawie wszystkie gatunki znane stamtąd rosły w Beskidzie Wyspowym trzydzieści lat temu. Nie odnaleziono tutaj jedynie 39 gatunków: Acarospora oligospora, A. smaragdula, Carbonea vorticosa, Diplotomma lutosum, Eiglera flavida, Hymenelia ceracea, Kiliasia tristis, Lecanora subaurea, Lecidea atomaria, Micarea erratica, Lithographa tesserata, Opegrapha dolomiticola, O. lithyrga, Perusaria aspergilla, P. flavicans, Porpidia albocaerulescens, P. cinereoatra, P. melinodes, Protothelenella corrosa, Psilolechia clavulifera, Rhizocarpon lavatum, Rh. lecanorinum, Rinodina bischoffii, R. gennari, Sarcogyne privigna, Stereocaulon pileatum, Strigula austriaca, Thelidium aeneovinosum, Th. aquaticum, Th. zahlbruckneri, Trapelia involuta, Verrucaria aethioboloides, V. calciseda, $V$. confluens, $V$. dolosa, $V$. funckiana, $V$. muralis, $V$. polygonia, $V$. sagedioides i $V$. sublobulata. Tylko niektóre z nich mogły być przeoczone, ale innych rzeczywiście nie było tutaj nigdy. Jest to bardzo znamienne w porównaniu $\mathrm{z}$ gatunkami nadrzewnymi i epiksylicznymi, których łącznie 69 gatunków nie rosło w Beskidzie Wyspowym.

Porosty naziemne. Gatunki takie rosły na glebie gliniastej, o wiele rzadziej na glebie torfiastej i humusowej. Flora naziemna była dosyć bogata. Występowały tu: Arthorhaphis citrinella, Baeomyces rufus, Cetraria islandica, Chaenotheca furfuracea (fakultatywny epigeit), Cladina arbuscula, C. ciliata var. tenuis, C. mitis, C. rangiferina, Cladonia caespiticia, C. cariosa, C. cenotea, C. cervicornis, C. chlorophaea, C. coccifera, C. coniocraea, C. cornuta, C. deformis, C. digitata. C. fimbriata, C. furcata, C. glauca, C. gracilis, C. phyllophora, C. pleurota, C. polycarpoides, C. pyxidata, C. ramulosa, C. rangiformis, C. squamosa, C. subulata, C. symphycarpa, $C$. turgida, Collema tenax, Dibaeis baeomyces, Diploschistes muscorum, Endocarpon pusillum, Epilichen scabrosus, Lepraria incana, Peltigera canina, $P$. didactyla, $P$. horizontalis, P. polydactyla, P. rufescens, Placynthiella oligotropha, P. uliginosa, Pycnothelia papillaria, Thrombium epigaeum, Trapeliopsis gelatinosa i $T$. granulosa. Zwłaszcza z rodzaju Cladina i Cladonia spotykano wówczas duże łany plech. Również częste były plechy rodzajów Peltigera, Placynthiella i Pycnothelia. Dziś pozostały 'niedobitki' z rodzajów Cladina i Cladonia: Cladonia caespiticia, C. chlorophaea, C. coniocraea, C. deformis, C. fimbriata, C. subulata. Żal zwłaszcza zupełnego ustąpienia z Beskidu Wyspowego Arthorhaphis citrinella, Cladonia turgida, Epilichen scabrosus, Pycnothelia papillaria i wszystkich gatunków z rodzaju Peltigera. Kilka gatunków nie zostało znalezionych trzydzieści lat temu w Beskidzie Wyspowym, a znane były z Beskidu Żywieckiego, np. Cetraria aculeata, C. ericetorum, Cladonia foliacea, Lempholemma chalazanellum, L. chalazanum i Peltigera lepidophora.

Porosty epibryofityczne. Na obumierających mchach naziemnych, niekiedy również nadrzewnych, w Beskidzie Wyspowym stwierdzono niezbyt wiele porostów. Są to Bacidia bagliettoana, Bryophagus gloeocapsa, Chromatochlamys muscorum, Cladonia 
pocillum, Diploschistes muscorum, Lempholemma polyanthes, Leptogium lichenoides, Mycobilimbia sabuletorum i Pannaria pezizoides. Spośród nich pozostały do dziś Cladonia pocillum, Leptogium lichenoides i Mycobilimbia sabuletorum; inne wyginęły całkowicie lub są bliskie wyginięcia. W Beskidzie Żywieckim ponad trzydzieści lat temu były zbierane dodatkowo Biatora carneoalbida i Mycobilimbia hypnorum.

Gatunki epiksyliczne. Duża grupa porostów znana była trzydzieści lat temu $\mathrm{z}$ martwego drewna. Gatunki takie rosły zarówno w środowisku naturalnym, na butwiejących pniakach, jak i antropogenicznym, np. na poręczach mostów, parkanach. W'śród tych gatunków spora część to gatunki górskie (reglowe); wyginęły one całkowicie lub prawie całkowicie.

Do gatunków reglowych - lub zachowujących się jak reglowe - należy zaliczyć: Absconditella lignicola, Bacidina phacodes, Calicium abietinum, Chaenotheca brunneola, Ch. xyloxena, Cladonia botrytes, Cybebe gracilenta, Lecidea turgidula, Micarea prasina, Mycocalicium subtile, Omphalina umbellifera, Parmeliopsis hyperopta, Sarcosagium campestre, Thelocarpon epibolum, Th.. intermediellum, Th. lichenicola, Thelomma ocellatum, Trapeliopsis viridescens i Xylographa abietina. Cała ta grupa gatunków obecnie nie występuje w Beskidzie Wyspowym.

Na martwym drewnie zbierano również inne gatunki: Amandinea punctata, Caloplaca holocarpa, Cladonia cenotea, C. coniocraea, C. digitata, C. fimbriata, C. macilenta, C. ochrochlora, Hypogymnia physodes, Lecanora pulicaris, L. saligna, $L$. sarcopidoides, $L$. symmicta, $L$. varia, Lepraria incana, Micarea denigrata, Parmeliopsis ambigua, Placynthiella uliginosa, Pseudevernia furfuracea, Rinodina pyrina, Thelocarpon laureri, Trapeliopsis flexuosa, Usnea hirta, Vulpicida pinastri, Xanthoria candelaria, $X$. parietina i $X$. polycarpa. Gatunki te są epiksylitami fakultatywnymi, rosną na bardzo różnym podłożu i prawie wszystkie pozostały do dnia dzisiejszego.

Tylko w Beskidzie Żywieckim występowały następujące gatunki: Calicium trabinellum, Chaenotheca brachypoda, Chaenothecopsis pusiola, Ch. viridialba, Icmadophila ericetorum i Ptychochroa flexella. Również one są gatukami reglowymi.

Gatunki nadrzewne. We florze Beskidu Wyspowego epifity stanowiły bardzo znaczącą grupę porostów. One też uległy w ostatnim trzydziestoleciu największym niekorzystnym zmianom, prawie całkowicie wyginęły. Największa liczba gatunków była związana $\mathrm{z}$ bukiem, co jest zupełnie zrozumiałe - jest to bowiem najważniejsze drzewo rosnące w tym obszarze. Również epifity buka uległy prawie całkowitej zagładzie. Drugim - pod względem ważności - forofitem dla tych organizmów - był jesion. Kolejnymi gatunkami drzew, dosyć ważnymi dla porostów były jawor, lipa, olcha szara, wierzba, topola razem z osiką i dąb. Dopiero w dalszej kolejności stanowiły je brzoza, klon zwyczajny, grab, jarzębina lub drzewa owocowe: jabłoń, grusza, orzech włoski, śliwa i wiśnia.

Znacznie mniej epifitów - choć w większości innych gatunków - rosło na korze drzew iglastych. Tutaj pierwsze miejsce zajmuje jodła, świerk, sosna i modrzew. Omówienie epifitów przedstawiono osobno dla każdego $\mathrm{z}$ tych drzew: 
- Epifity buka zwyczajnego Fagus sylvatica. W latach 1966-1967 na korze buka stwierdzono następujące gatunki porostów epifitycznych: Arthonia mediella, A. radiata, A. vinosa, Bacidia globulosa, Bacidia rubella, B. cf. viridula, Biatora efflorescens, Buellia griseovirens, Caloplaca cerina, Cetrelia cetrarioides, Cladonia digitata, Evernia prunastri, Flavoparmelia caperata, Graphis scripta, Hypogymnia physodes, H. vittata, Lecanora albella, L. argentata, L. carpinea, L. conizaeoides, L. intumescens, L. pulicaris, L. subcarpinea, L. subrugosa, Lecidea pullata, Lecidella elaeochroma, Lepraria incana, Lobaria pulmonaria, Melanelia fuliginosa, M. subaurifera, Menegazzia terebrata, Mycobilimbia sabuletorum, Ochrolechia androgyna, Opegrapha rufescens, O. varia, O. viridis, O. vulgata, Parmelia saxatilis, P. sulcata, Parmeliopsis ambigua, Peltigera degenii, P. praetextata, Pertusaria albescens, P. alpina, P. amara, P. coronata, $P$. hemisphaerica, $P$. leioplaca, P. pertusa, Phaeophyscia endophoenicea, Phlyctis argena, Platismatia glauca, Porina aenea, Pseudevernia furfuracea, Pyrenula laevigata, P. nitida, Ramalina farinacea, Thelotrema lepadinum, Usnea filipendula i U. subfloridana. Nie znaleziono tutaj następujących gatunków, które rosły na bukach w Beskidzie Żywieckim: Arthopyrenia grisea, Bacidia beckhausii, B. subincompta, Belonia herculina, Caloplaca herbidella, Cetrelia olivetorum, Dimerella diluta, Gyalecta flotowii, G. ulmi, Melaspilea gibberulosa, Mycoblastus affinis, Nephroma parile, $N$. resupinatum, Normandina pulchella, Opegrapha ochrocheila, Parmeliella triptophylla, Rinodina exigua, Sclerophora nivea i Strigula stigmatella. Obecnie na bukach w Beskidzie Wyspowym pozostało bardzo niewiele gatunków: Buellia griseovirens i Graphis scripta (bardzo rzadkie stanowiska), Hypogymnia physodes i Lecanora pulicaris (nieliczne stanowiska), Lecanora conizaeoides (obecnie gatunek bardzo pospolity), Lecidella elaeochroma, Lepraria incana, Melanelia fuliginosa, Parmelia saxatilis, Parmeliopsis ambigua, Pertusaria amara i Phlyctis argena. Są to porosty rosnące na różnych gatunkach drzew, nie charakterystyczne dla buka. Wszystkie gatunki typowo buczynowe $w$ tych górach już nie występują.

- Epifity jesionu wynioslego Fraxinus excelsior. Jesiony rosną głównie nad potokami, niekiedy również wzdłuż dróg. Na korze tego drzewa występowały następujące gatunki porostów: Amandinea punctata, Arthonia radiata, Candelaria concolor, Candelariella xanthostigma, Evernia prunastri, Flavoparmelia caperata, Hypogymnia physodes, $H$. tubulosa, Lecanora argentata, L. carpinea, L. chlarotera, L. expallens, L. pulicaris, Lecidella elaeochroma, Melanelia elegantula, M. exasperatula, M. fuliginosa, M. subargentifera, M. subaurifera, Opegrapha rufescens, Parmelia sulcata, Parmelina tiliacea, Pertusaria albescens, P. amara, Phaeophyscia orbicularis, Physcia adscendens, Ph. aipolia, Ph. stellaris, Ph. tenella, Ph. wainioi, Physconia distorta, Ph. enteroxantha, Ph. perisidiosa, Pseudevernia furfuracea, Punctelia subrudecta, Usnea hirta, Xanthoria candelaria, X. fallax, X. parietina $i X$. polycarpa. W Beskidzie Żywieckim na jesionach rosły ponadto: Anaptychia ciliaris, Melanelia exasperata, M. glabra, M. laciniatula, Physcia tribacia, Physconia grisea, Ramalina fallax, R. fastigiata, R. fraxinea $i$ Xanthoria ulophyllodes. Obecnie w Beskidzie Wyspowym na jesionach pozostały między innymi - jako rzadkie lub bardzo rzadkie - gatunki wyżej wymienione, tyle że bardzo ogra- 
niczyły swoją pospolitość. Jako dość rzadkie lub bardzo rzadkie spotkać można tutaj jeszcze Amandinea punctata, Candelaria concolor, Hypogymnia physodes, Lecidella elaeochroma, Melanelia fuliginosa, Parmelia sulcata, Pertusaria albescens, P. amara, Phaeophyscia orbicularis, Physcia adscendens, Punctelia subrudecta, Xanthoria parietina. Wyginęły (lub giną) tak niegdyś częste na tym drzewie: Physcia aipolia, Ph. stellaris, Physconia distorta, Ph. enteroxantha i Ph. perisidiosa.

- Epifity jawora Acer pseudoplatanus. Jawory rosną razem z bukami, ale posiadały znacznie mniej od niego gatunków. Są to następujące taksony: Amandinea punctata, Buellia disciformis, B. griseovirens, Candelariella xanthostigma, Evernia prunastri, Flavoparmelia caperata, Graphis scripta, Hypogymnia physodes, Lecanora argentata, L. carpinea, L. chlarotera, L. conizaeoides, L. pulicaris. Melanelia exasperatula, M. fuliginosa, Opegrapha rubescens, Parmelia sulcata, Pertusaria albescens, P. amara, Phaeophyscia endophoenicea, Phlyctis argena, Physcia adscendens, Physconia enteroxantha, Ramalina farinacea i Xanthoria polycarpa. W Beskidzie Żywieckim rosły ponadto: Bacidia globulosa, Biatora cf. meiocarpa, Calicium viride, Caloplaca herbidella, Hypogymnia farinacea, Lecanora albella, L. intumescens, L. leptyrodes, Lobaria pulmonaria, Megalaria pulverea, Melanelia glabra, M. laciniatula, Menegazzia terebrata, Ochrolechia androgyna, O. subviridis, Opegrapha viridis, O. vulgata, Pertusaria coccodes, $P$. coronata, $P$. hemisphaerica, Platismatia glauca, Ramalina fastigiata, R. fraxinea, Rinodina pyrina, Scoliciosporum chlorococcum i Thelotrema lepadinum. Z tego porównania widać, że już w latach siedemdziesiątych w Beskidzie Wyspowym flora jawora była bardzo uboga. Dzisiaj ten proces jeszcze bardziej się pogłębił.

- Epifity lipy Tilia sp. div. Stare lipy posiadały dość bogatą, choć niezbyt interesującą florę epifityczną pod względem jej składu gatunkowego; były to następujące gatunki porostów: Amandinea punctata, Candelaria concolor, Candelariella xanthostigma, Evernia prunastri, Flavoparmelia caperata, Lecanora argentata, L. carpinea, L. chlarotera, L. conizaeoides,. L. pulicaris, L. saligna, Lepraria incana, Melanelia exasperatula, M. fuliginosa, Parmelia saxatilis, P. sulcata, Parmelina tiliacea, Pertusaria albescens, P. amara, Phlyctis argena, Phaeophyscia orbicularis, Physcia adscendens, Ph. aipolia, Physconia distorta, Ph. enteroxantha, Pseudevernia furfuracea, Punctelia subrudecta, Ramalina pollinaria, Usnea hirta, Xanthoria candelaria, X. fallax i X. parietina. Jest to przeciętna flora, której skład gatunkowy obecnie bardzo zubożał.

- Epifity olszy szarej Alnus incana. Olsza szara stanowi do dzisiaj bardzo ważny składnik drzewostanów rosnących nad wszystkimi potokami i rzekami karpackimi. Flora epifityczna tego drzewa w Beskidzie Wyspowym nie była nigdy zbyt bogata ani bardziej interesująca pod względem składu gatunkowego. Rosły tu: Arthothelium ruanum, Buellia griseovirens, Caloplaca holocarpa, Candelariella xanthostigma, Evernia prunastri, Flavoparmelia caperata, Graphis scripta, Hypogymnia physodes, Lecanora carpinea, L. pulicaris, Lecidella elaeochroma, Melanelia fuliginosa, Menegazzia terebrata, Ochrolechia subviridis, Opegrapha vulgata, Parmelia saxatilis, P. sulcata, Parmelina tiliacea, Parmeliopsis ambigua, Pertusaria 
amara, Phlyctis argena, Pseudevernia furfuracea, Punctelia subrudecta, Pyrenula nitida i Scoliciosporum chlorococcum. Obecnie jej skład został również bardzo ograniczony. Wymarła większość gatunków listkowatych, wyginęły również lub prawdopodobnie zginą $\mathrm{w}$ najbliższym czasie, niektóre porosty skorupiaste, np. Arthothelium ruanum, Graphis scripta, Lecanora carpinea, L. pulicaris, Ochrolechia subviridis, Opegrapha vulgata i Pyrenula nitida. Na olszy szarej w Beskidzie Żywieckim znane były jeszcze następujące epifity: Arthopyrenia punctiformis, Dimerella diluta, Lecanora chlarotera, L. subcarpinea, L. symmicta, Stenocybe pullatula i Vulpicida pinastri.

- Epifity dębu Quercus sp. div. Porosty rosnące na dębach nie były już trzydzieści lat temu zbyt liczne ani interesujące. Rosły tu następujące gatunki: Amandinea punctata, Arthonia punctiformis (na korze bardzo młodych dębów), Candelariella xanthostigma, Evernia prunastri, Flavoparmelia caperata, Hypogymnia physodes, Lecanora argentata, L. carpinea, L. chlarotera, L. pulicaris, Lecidella elaeochroma, Melanelia exasperatula, M. fuliginosa, Parmelia saxatilis, P. sulcata, Parmelina tiliacea, Phlyctis argena, Physcia tenella, Ramalina farinacea i Xanthoria polycarpa. Na dębach w Beskidzie Żywieckim zbierano ponadto: Bacidia globulosa, Caloplaca herbidella, Cetrelia cetrarioides, Lecanora albella, L. allophana, Melanelia laciniatula, Pertusaria albescens, P. coccodes, Physcia aipolia, Physconia perisidiosa, Ramalina fastigiata i Usnea hirta. Większość gatunków porostów żyjących na dębach w Beskidzie Wyspowym dzisiaj już wyginęła. Podobnie jest z gatunkami, które przed trzydziestu laty rosły na korze klonu Acer platanoides, grabu Carpinus betulus i jarzębiny Sorbus aucuparia; ich skład zawsze był ubogi.

- Epifity brzozy brodawkowatej Betula pendula. Skład gatunkowy porostów tego drzewa jest podobny do składu epifitów drzew iglastych, lecz znacznie uboższy. $\mathrm{Na}$ korze brzozy rosły następujące gatunki: Bryoria crispa, B, positiva, Cladonia digitata, Evernia prunastri, Hypogymnia physodes, Lecanora conizaeoides, L. varia, Lepraria incana, Melanelia exasperatula, Parmelia saxatilis, Parmeliopsis ambigua, Platismatia glauca, Pseudevernia furfuracea, Trapeliopsis flexuosa i Vulpicida pinastri.

- Epifity wierzby Salix sp. div., topoli Populus sp. div. i osiki Populus tremula. Dość liczną florę gatunków epifitycznych posiadała wierzba. Bardzo do niej zbliżony skład gatunkowy występował na topoli oraz na osice. Na drzewach tych występowały następujące gatunki porostów: Acrocordia gemmata, Amandinea punctata, Bacidia rubella, Caloplaca holocarpa, Candelaria concolor, Candelariella xanthostigma, Evernia prunastri, Flavoparmelia caperata, Hypogymnia physodes, $H$. tubulosa, Lecanora argentata, L. carpinea, L. chlarotera, L. expallens, L. hegeni, L. pulicaris, L. saligna, Lecidella elaeochroma, Lepraria incana, Melanelia exasperatula, M. fuliginosa, M. subargentifera, Ochrolechia arborea, O. subviridis, O. turneri, Opegrapha rufescens, O. varia, Parmelia saxatilis, P. sulcata, Parmelina tiliacea, Pertusaria albescens, P. amara, Phaeophyscia endophoenicea, Ph. nigricans, Ph. orbicularis, Phlyctis argena, Physcia adscendens, Ph. aipolia, Ph. stellaris, Ph. tenella, Physconia distorta, Ph. enteroxantha, Ph. perisidiosa, Pseudevernia furfuracea, Punctelia subrudecta, Rinodina colobina, Xanthoria fallax, 
$X$. parietina i $X$. polycarpa. Większość porostów stanowią tutaj gatunki listkowate; liczne spośród nich wyginęły na tym typie podłoża. Z Beskidu Żywieckiego znane były z tych drzew jeszcze następujące porosty: Caloplaca cerina, Lecanora rugosella, Melanelia glabra, Parmelina quercina, Phaeophyscia hirsuta, Physconia grisea, Ramalina fastigiata i $R$. fraxinea.

- Epifity drzew owocowych. W Beskidzie Wyspowym do najczęściej spotykanych drzew owocowych należą jabłoń Malus, grusza Pirus, śliwa Prunus i orzech włoski Juglans regia. $\mathrm{Na}$ drzewach tych gatunki porostów były spisywane raczej przypadkowo, dlatego lista ta nie zawiera wszystkich zasiedlających je taksonów. Do takich, które zostały zaobserwowane należą następujące: Acrocordia gemmata, Amandinea punctata, Candelaria concolor, Candelariella xanthostigma, Flavoparmelia caperata, Hypogymnia physodes, Lecanora carpinea, L. pulicaris, Lecidella elaeochroma, Lepraria incana, Melanelia exasperatula, Parmelia saxatilis, $P$. sulcata, Parmelina tiliacea, Pertusaria albescens, P. amara, Phaeophyscia nigricans, Ph. orbicularis, Phlyctis argena, Physcia adscendens, Ph. tenella, Physconia enteroxantha, Xanthoria fallax, X. parietina i $X$. polycarpa.

- Epifity jodły pospolitej Abies alba. Jodła jest naturalnym składnikiem lasów dolnoreglowych. Jej flora epifityczna w Beskidzie Wyspowym już trzydzieści lat temu była bardzo zubożała i ograniczona do gatunków pospolitszych. Na korze tego drzewa osiedlały się następujące porosty: Amandinea punctata (wyjątkowo pojawia się na tym drzewie), Arthonia mediella, Biatora efflorescens, Bryoria crispa, B. positiva, Buellia schaereri, Chaenotheca chrysocephala, Ch. ferruginea, Ch. furfuracea (rośnie w jamkach u nasady pni drzewa), Chrysothrix candelaris, Graphis scripta, Hypocenomyce scalaris, Hypogymnia farinacea, $H$. physodes, $H$. tubulosa, Imshaugia aleurites, Lecanora argentata, L. conizaeoides, L. varia, Lecidea pullata, Lepraria incana, Melanelia fuliginosa, Opegrapha vulgata, Parmelia saxatilis, Parmeliopsis ambigua, P. hyperopta, Pertusaria amara, Platismatia glauca, Pseudevernia furfuracea, Scoliciosporum chlorococcum, Tuckermannopsis chlorophylla, Usnea filipendula, U. glauca, U. hirta i Vulpicida pinastri. Jak duże było to zubożenie niech świadczą gatunki występujące wówczas na jodle w Beskidzie Żywieckim: Arthonia leucopellea, Alectoria bicolor, Bryoria fuscescens, B. nadvornikiana, Calicium abietinum, Chaenotheca stemonea, C. trichialis, Cliostomum griffithii, Hypocenomyce caradocensis, Lecanactis abietina, Lecanora albella, Loxospora cismonica, Microcalicium disseminatum, Mycoblastus sanguinarius, Ochrolechia androgyna, Pertusaria hemisphaerica, Ramalina farinacea, Stenocybe major, Thelotrema lepadinum, Trapeliopsis flexuosa i U. subfloridana. Dzisiaj pnie jodeł są w większości przypadków prawie pozbawione porostów.

- Epifity świerka pospolitego Picea abies. Świerk w Beskidzie Wyspowym jest drzewem sadzonym. Za jego naturalną ostoję można było uważać tylko sam wierzchołek góry Mogielicy, dopóki leśnicy nie wycięli tam nikłego fragmentu regla górnego. Świadczą o tym gatunki epifityczne, jakie osiedlają się na tym drzewie. Jak bardzo drzewo to było pozbawione naturalnych porostów świerczynowych już trzydzieści lat temu, niech świadczy poniższa lista: Bryoria bicolor, B. positiva, Chaenotheca chrysocephala, Ch. ferruginea, Ch. furfuracea, Ch. ste- 
monea, Cladonia digitata, C. fimbriata, Hypocenomyce scalaris, Hypogymnia physodes, H. vittata, Imshaugia aleurites, Lecanora conizaeoides, L. pulicaris, Lepraria incana, Melanelia fuliginosa, Mycoblastus sanguinarius, Parmelia saxatilis, Parmeliopsis ambigua, Platismatia glauca, Pseudevernia furfuracea, Scoliciosporum chlorococcum, Trapeliopsis flexuosa, Tuckermannopsis chlorophylla, T. sepincola, Usnea filipendula i Vulpicida pinastri. Z wymienionych gatunków tylko nieliczne są gatunkami reglowymi. Należą do nich: Bryoria bicolor, Hypogymnia vittata i Mycoblastus sanguinarius. W Beskidzie Żywieckim na świerkach rosły ponadto: Alectoria sarmentosa, Arthonia leucopellea, Bacidia naegelii, Biatora chrysantha, B. efflorescens, Bryoria catharinae, B. crispa, B. fuscescens, B. implexa, B. mirabilis, B. motykana, B. nadvornikiana, B. setacea, B. sophiae, B. subcana, B. vrangiana, Calicium abietinum, C. lenticulare, C. viride, Chaenotheca phaeocephala, Ch. stemonea, Ch. trichialis, Chaenothecopsis consociata, Cybebe gracilenta, Hypocenomyce caradocensis, $H$. sorophora, Hypogymnia bitteri, $H$. farinacea, $H$. tubulosa, Lecanactis abietina, Lecanora sarcopidoides, Lecidea pullata, Lopadium pezizoideum, Loxospora elatina, Micarea melaena, Mycoblastus affinis, Ochrolechia androgyna, O. turneri, Opegrapha vulgata, Parmeliopsis hyperopta, Pertusaria coccodes, Schismatomma pericleum, Sphaerophorus globosus i Xanthoria candelaria. Są to prawie wszystko gatunki reglowe. Ich obecność w Beskidzie Żywieckim jest związana $\mathrm{z}$ dużymi powierzchniami pokrytymi przez piętro regla górnego, co wynika ze znacznej wysokości tych gór.

- Epifity sosny pospolitej Pinus sylvestris i modrzewia europejskiego Larix decidua. Sosna i modrzew nie odgrywają w Beskidach zbyt wielkiej roli jako siedlisko epifitów. W Beskidzie Wyspowym na ich korze rosły następujące gatunki: Bryoria positiva, Chaenotheca chrysocephala, Ch. ferruginea, Cladonia digitata, Hypocenomyce scalaris, Hypogymnia physodes, $H$. tubulosa, Imshaugia aleurites, Lecanora carpinea (wyjątkowo na sośnie), L. conizaeoides, L. piniperda, L. pulicaris, $L$. sarcopidoides, Lepraria incana, Parmeliopsis ambigua, Platismatia glauca, Pseudevernia furfuracea, Scoliciosporum chlorococcum, Trapeliopsis flexuosa, Tuckermannopsis chlorophylla i Vulpicida pinastri. Obecnie na sosnach spotykano tylko: Hypocenomyce scalaris, Hypogymnia physodes (dość rzadko), Lecanora conizaeoides (nadzwyczaj często), Lepraria incana, Scoliciosporum chlorococcum i Trapeliopsis flexuosa (rzadko). W Beskidzie Żywieckim nie zanotowano ani jednego gatunku więcej na obu drzewach.

\section{POROSTY BESKIDU WYSPOWEGO}

\section{Wykaz stanowisk (Ryc. 1) - List of localities (Fig. 1)}

Objaśnienia skrótów (Abbreviations): dol. - dolina (valley); g. - góra (mountain); H. - hala (alpine pasture); k. - koło (near); m. - między (between); N - północny (northern); pol. - polana (glade); pot. - potok (stream); przys. - przysiółek (thorp); S - południowy (southern). 
1. g. Adamczykowa (Mszana Dolna); 2. pot. Adamczyków (Mszana Dolna); 3. pot. Antosów (Mszana Dolna); 4. przys. Antosy (Mszana Dolna); 5. g. Babia Góra (Kłodne); 6. przys. Bajki (Raba Niżna); 7. pot. Bajtków Potok (Kasinka Mała); 8. przys. Bednarki (Rupniów); 9. przys. Białe (Szczawa); 10. przys. Białkówka (Raba Niżna); 11. przys. Biedaki (Olszówka); 12. przys. Bołdony (Mszana Dolna); 13. przys. Brogi (Gruszowiec); 14. pol. Brogi (Szczawa); 15. przys. Bruski (Półrzeczki); 16. dol. pot. Czerwone; 17. przys. Brzeg (Stara Wieś); 18. pot. Brzeźna (Brzeźna); 19. przys. Brzeźna (Podegrodzie); 20. przys. Budacze (Gruszowiec); 21. pol. Budaczowa (Półrzeczki); 22. przys. Burdak (Długołęka); 23. przys. Bukowina (Zalesie); 24. przys. Bulandy (Szczawa); 25. przys. Burdy (Kamienica); 26. g. Bydłoniowa (Kasinka Mała); 27. Bystra Góra (Szczawa); 28. g. Byniowa (Kamienica); 29. przys. Byniowa (Kamienica); 30. pot. Byniowa (Kamienica); 31. przys. Cabałówka (Przyszowa); 32. przys. Cecygówka (Łukowica); 33. g. Chełm (Kłodne); 34. przys. Chełm (Kłodne); 35. przys. Chumowa (Kamionka Mała); 36. przys. Chyszówki (Chyszówki); 37. przys. Ciastonie lub Ciastoniówka (Wierzbanowa); 38. przys. Ciże (Kasinka Mała); 39. przys. Czarna Rzeka (Słopice); 40. g. Czarny Dział (Kasina Wielka); 41. g. Cymbałowa (Lubień); 42. g. Cyrki (Lubomierz); 43. g. Cyrla (Słopnice); 44. g. Ćwilin; 45. H. Ćwilin; 46. przys. Dawce (Mszana Górna); 47. pot. Dawce (Mszana Dolna); 48. przys. Dębina (Mystków w Beskidzie Sądeckim); 49. przys. Dobrocierz (Dobrocierz); 50. przys. Do Fudali (Olszówka); 51. pot. Do Uboczy (Chyszówka); 52. Dobra; 53. przys. Dobrzany (Kasinka Mała); 54. Drużków Pusty k. Dobrocierza; 55. przys. Dudziki (Łostówka); 56. przys. Dwór (Węglówka); 57. przys. Dwór (Piekiełko); 58. przys. Dymały (Kasinka Wielka); 59. g. Dzielec (Łososina Górna); 60. g. Dzielec (Kasina Wielka); 61. przys. Fargamusy (Łostówka); 62. przys. Filipcowa (Tenczyn); 63. przys. Filipiaki (Kasina Mała); 64. pol. Folwarczana (Półrzeczki); 65. przys. Folwark (Jurków); 66. przys. Fudaleje (Półrzeczki); 67. pot. Gajduszowiec (Długołęka); 68. pot. Głębowski (Kasinka Mała); 69. przys. Głowaczyzna (Rajbrot); 70. przys. Golcowa (Tenczyn); 71. G. Golców (Siekierczyna); 72. przys. Górniówka (Lubień); 73. przys. Granica (Limanowa); 74. przys. Granica (Stańkowa); 75. przys. Groszowa (Mszana Dolna); 76. G. Groń (Chyżówki); 77. przys. Groń Herby (Wierzbanowa); 78. przys. Groty (Kasinka Mała); 79. przys. Growaczyzna (Kamionka); 80. g. Gródek (Kasinka Mała); 81. g. Grójec (Zawadka); 82. g. Gwizdor (Długołęka); 83. g. Hajdowska Góra (Słopnice); 84. g. Hala (Szczawa); 85. obóz Imka (Kasinka Mała); 86. dol. Jabłoniec (Laskowa); 87. przys. Jakubiaki (Kasinka Mała); 88. pot. Jamne (Półrzeczki); 89. przys. Janie (Mszana Górna); 90. przys. Janie (Jurków); 91. pol. Janiowa (Jurków); 92. przys. Janówka (Raba Niżna); 93. g. Jasień (Jasień); 94. g. Jasieńczyk (Młyńczyska); 95. Jastrzębie; 96. g. Jaworze (Stańkowa); 97. pol. Jaworze (Dobra); 98. przys. Jaworze (Lukowica); 99. dol. Jaworzna (Jaworzna); 100. Jaworzna; 101. przys. Jeżowa Woda (Młyńczyska); 102. g. Kamera (Długołęka); 103. dol. Kamionki Małej (Kamionka Mała); 104. g. Kamionna (Kamionna); 105. przys. Karczma (Dobra [= Stara Karczma]); 106. przys. Kalety (Kasina Wielka); 107. g. Kamionka (Kasinka Mała); 108. przys. Karpieńcowa (Tenczyn); 109. przys. Karpierzowa (Tenczyn); 110. Kasina Wielka; 111. przys. Kęcina (Limanowa); 112. przys. Kicznia (Łącko); 113. g. Kiczora (Kasina Mała); 


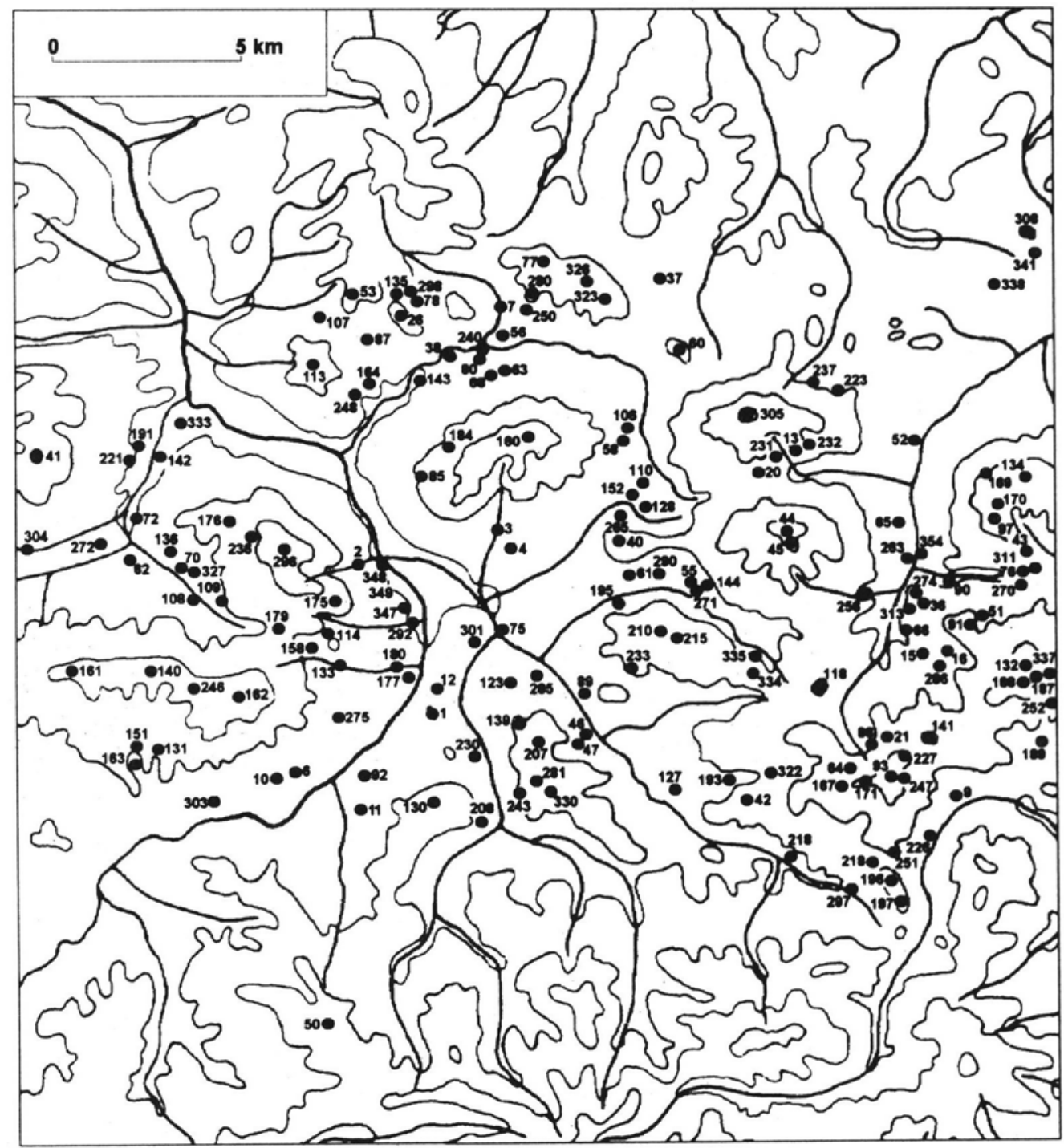

Ryc. 1. Rozmieszczenie stanowisk porostów w Beskidzie Wyspowym (opracowanie B. MORAWSKA-NOWAK)

114. przys. Kiece (Glinne); 115. Kisielówka k. Piekiełka; 116. przys. Klenie (Kłodne); 117. Klęczany; 118. g. Kobylica (Półrzeczki); 119. g. Kobyła (Rajbrot); 120. Kobyłczyna k. Laskowej; 121. przys. Kobyłczyna Niżna (Kobyłczyna koło Ujanowic); 122. przys. Kobyłczyna Wyżnia (Kobyłczyna k. Ujanowic); 123. g. Kocia Górka (Mszana Dolna); 124. g. Komera (Długołęka); 125. przys. Kopciówka (Mordarka); 126. g. Kopiec (Krosna); 127. przys. Kopytki (Mszana Górna); 128. przys. Kordówka (Kasina Wielka); 129. g. Kostrza (Rupniów); 130. g. Kotelnica (Niedźwiedź); 131. pot. 


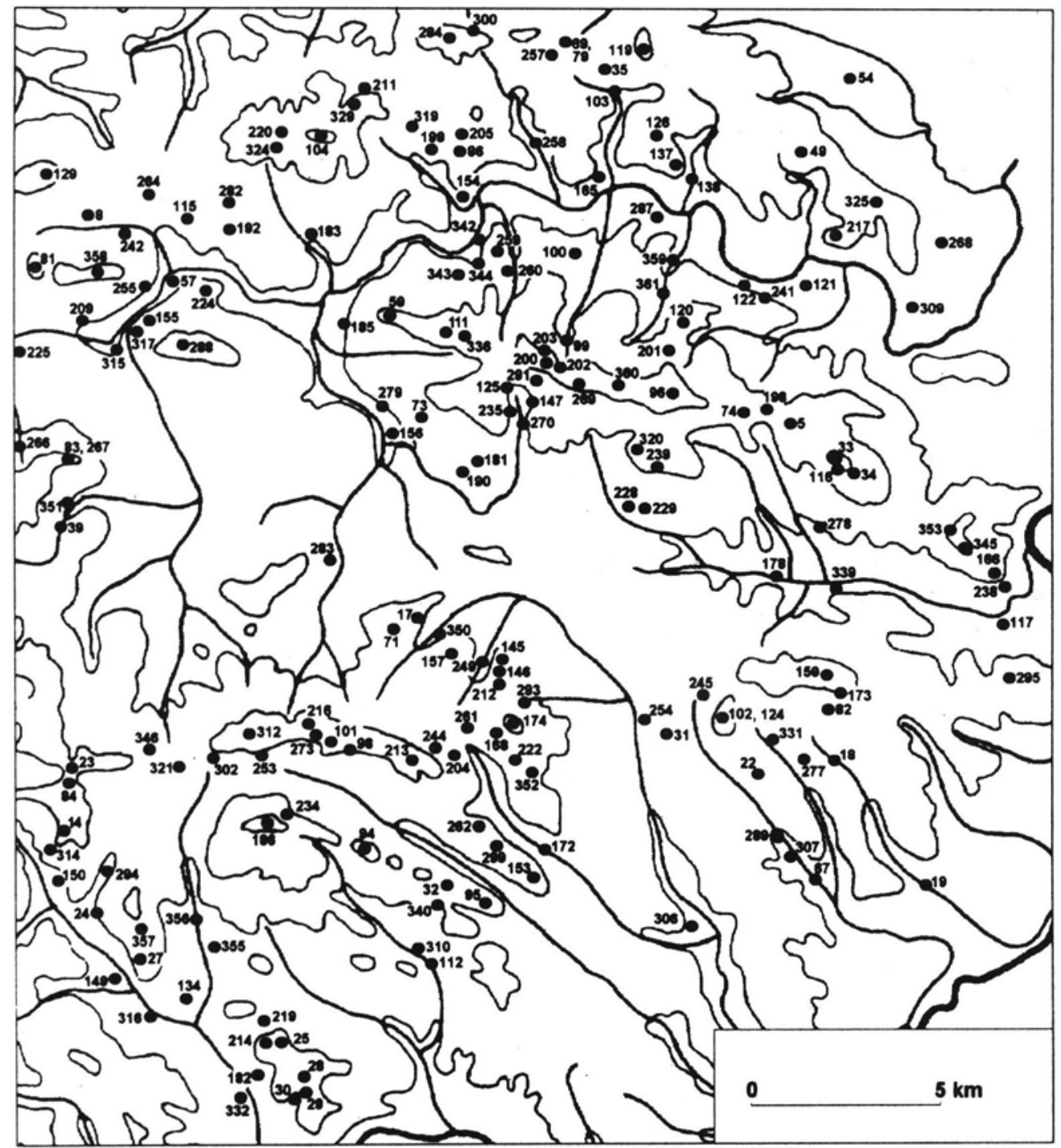

Fig. 1. Distribution of lichen localities in the Beskid Wyspowy Range (by B. MORAWSKA-NowAK)

Kozi (Rabka); 132. pol. Kozice (g. Mogielica); 133. pot. Kozieniec (Glisne); 134. przys. Kozłówka (Kamienica); 135. przys. Kozówka (Kasinka Mała); 136. przys. Krętowa lub Krętoniowa (Tenczyn); 137. Krosna koło Laskowej; 138. dol. Krosnej (Krosna); 139. przys. Krzynów (Mszana Górna); 140. przys. Krzysie (Luboń Wielki); 141. g. Krzysztonów (Półrzeczki); 142. przys. Kubińcowa (g. Luboń Wielki); 143. przys. Kuce (Kasinka Mała); 144. przys. Kuczaje (Łostówka); 145. g. Kukłacz (Siekierczyna); 146. pol. Kuklacz (Siekierczyna); 147. przys. Kunówka (Mordarka); 
148. przys. Kurczaby (Limanowa) brak cytowań w liście gatunków; 149. przys. Kurzejówka (Kamienica); 150. przys. Kuźle (Szczawa); 151. Las Luboński; 152. Las Puciaki (Kasina Wielka); 153. przys. Lasek (Łukowica); 154. Laskowa; 155. przys. Lemirze (Piekiełko); 156. Limanowa; 157. przys. Lisia Góra (Siekierczyna); 158. przys. Liski (Glisne); 159. g. Litacz (Wysokie); 160. g. Lubogoszcz; 161. g. Luboń Mały (Skomielna Biała); 162. g. Luboń Wielki; 163. pot. Luboński Potok (Rabka); 164. przys. Łabuzy (Kasinka Mała); 165. przys. Łagoszówka (Kamionka); 166. przys. Łazy (Chomranice); 167. Łąki; miejsce koło Lubomierza; 168. przys. Łąki (Siekierczyna); 169. przys. Łęczyska (Dobra); 170. g. Łopień; 171. pol. Łuki (g. Jasień); 172. Łukowica; 173. g. Łysa Góra (Trzetrzewina); 174. g. Łyżka lub Wyżka (Siekierczyna; 175. g. Mała Góra (g. Szczebel); 176. g. Mały Groń (Lubień); 177. przys. Marczaki (Raba Niżna); 178. Męcina; 179. przys. Michalaki (Tenczyn Górny); 180. pot. Miedziany (Raba Niżna); 181. pot. Między Brzegi (Mordarka); 182. przys. Mikołajczyki (Kamienica); 183. Młynne; 184. Las Mocarze (g. Lubogoszcz); 185. przys. Moczarki (Sowliny); 186. g. Modyń (Zalesie); 187. g. Mogielica; 188. H. Mogielica (g. Mogielica); 189. pot. Mogielica (Szczawa); 190. Mordarka; 191. przys. Moskałowa (Lubień); 192. pot. Mroczkówki (Pasierbiec); 193. przys. Muszyny (Mszana Górna); 194. pol. Myconiówka (g. Łopień); 195. przys. Myszoglądy (Łostówka); 196. g. Myszyca (Lubomierz); 197. pol. Na Foksowym (Lubomierz); 198. przys. Na Górach (Kłodne); 199. gajówka Na Górze (Laskowa); 200. Na Jaworzu (Jaworzna); 201. przys. Na Kolonii (Żmiąca); 202. przys. Na Korabie (Jaworzna); 203. przys. Na Padole (Jaworzna); 204. przys. Na Paryjach (Siekierczyna); 205. przys. Nagórze (Laskowa); 206. przys. Na Snoze (Kasinka Mała); 207. przys. Na Witów (Mszana Górna); 208. Niedźwiedź; 209. przys. Nowy Dwór (Tymbark); 210. g. Ogorzała (Łostówka); 211. przys. Ogrelówka (Żegocina); 212. przys. Ogrojec (Siekierczyna); 213. g. Okowaniec (Siekierczyna); 214. przys. Okrąg (Kamienica); 215. g. Ostra (Łostówka); 216. g. Ostra (Młyńczyska); 217. przys. Pagórek (Kobyłczyna); 218. przys Panki (Lubomierz); 219. przys. Paryż (Wola Pikulina); 220. g. Pasierbicka Góra (Pasierbiec); 221. przys. Pasiowa (Lubień); 222. g. Pępkówka (Łukowica); 223. przys. Piechówka (Dobra); 224. Piekiełko nad Łososiną; 225. przys. Pietoniówka (Tymbark); 226. pol. Piekło (Szczawa); 227. pol. Pieżgula (g. Jasień); 228. przys. Piramowa (Pisarzowa); 229. Pisarzowa; 230. przys. Piwowary (Podobin); 231. przys. Płoszczyce (Gruszowiec); 232. przys. Pod Górą (Gruszowiec); 233. przys. Pod Gronią (Mszana Górna); 234. przys. Pod Modyniem (Młyńszczyska); 235. przys. Pod Rębiskiem (Mordaeka); 236. Pod Szczebel (g. Szczebel); 237. przys. Pod Śnieżnicą (Dobra); 238. przys. Poddąbrowie (Klęczany); 239. przys. Podgórze (Pisarzowa); 240. przys. Podgródek (Kasina Mała); 241. przys. Podlesie (Kobyłczyna); 242. przys. Podlesie (Rupniów); 243. Podobin (Niedźwiedź); 244. przys. Podokowaniec (Siekierczyna); 245. przys. Podpiekle (Długołęka); 246. Pokrzywnik (g. Luboń Wielki); 247. pol. Polana Skalne (g. Jasień); 248. przys. Potok (Kasinka Mała); 249. przys. Potoki (Siekierczyna); 250. przys. Przylasek (Węglówka); 251. przys. Przysłopek (Lubomierz); 252. pol. Przysłopek (g. Mogielica); 253. przys. Przysłop (Zalesie); 254. Przyszowa; 255. przys. Rola (Dobra); 256. pot. Rosochaniec (Jurków); 257. przys. Rosochodka (Rozdziele); 258. dol. Rozdziele (Laskowa); 
259. przys. Rozpite (Laskowa); 260. pot. Rozpracki Potok (Laskowa); 261. dol. Roztoka (Roztoka); 262. Roztoka w pasmie Skiełka; 263. przys. Rubisie (Jurków); 264. Rupniów; 265. przys. Rusiny (Kasina Wielka); 266. pot. Rybny Potok (g. Łopień); 267. g. Rydznik (= Hajdowska Góra; Słopnice); 268. przys. Sadowa (Łososina Dolna); 269. g. Sałasz (Mordarka); 270. przys. Sarczyn (Mordarka); 271. przys. Sępki (Łostówka); 272. przys. Siepańcowa (Krzeczów); 273. g. Sikorzec (Roztoka, Przys. Słomiana (Młynne); 274. przys. Smolenie (Chyszówki); 275. pot. Sochy (Raba Niżna); 276. przys. Sorysz (Chyszówki); 277. g. Soślina (Długołęka); 278. przys. Sośniny (Męcina); 279. Sowliny k. Limanowej; 280. przys. Sowy (Węglówka); 281. g. Spyrkowa (Niedźwiedź); 282. przys. Stara Karczma (Pasierbiec); 283. Stara Wieś k. Limanowej; 284. g. Stawiska (Żegocina); 285. przys. Stecki (Mszana Górna); 286. pol. Stuse (Półrzeczki); 287. Strzeszyce; 288. g. Styr (Tymbark [= g. Paproć]); 289. pot. Suchy (Długołęka); 290. przys. Sutory (Łostówka); 291. przys. Szałas (Mordarka) 292. pot. Szarków (Mszana Dolna); 293. przys. Szarówka (Siekierczyna); 294. pot. Szczawa; 295. g. Szcząb (Klęczany); 296. g. Szczebel; 297. przys. Szczypty (Lubomierz); 298. przys. Szewczyki (Kasinka Mała); 299. g. Szkiełek (Łukowica); 300. g. Szklarka (Rozdziele); 301. przys. Szynaliki (Mszana Dolna); 302. przys. Ślagi (Zalesie); 303. przys. Śmietanowa (Rabka); 304. dol. pot. Śmigawka (Krzeczów); 305. g. Śnieżnica; 306. Świdnik; 307. Świrkla k. Długołęki; 308. g. Świnia Góra lub Świnna (Zawadka); 309. przys. Tłoki (Łososina Dolna); 310. przys. Tokarze (Kicznia); 311. przys. Tokarzówka (Chyszówki); 312. g. Tokoń (Zalesie); 313. przys. Tracze (Półrzeczki); 314. g. Turnia (Szczawa); 315. Tymbark; 316. przys. Udziele (Kamienica); 317. przys. Węglarka (Tymbark); 318. Węglarnia (Rypniów); 319. g. Widoma (Laskowa); 320. g. Wielka Góra (Pisanowa); 321. przys. Wierchy (Zalesie); 322. pot. Wierzbanica (Lubomierz); 323. g. Wierzbanowska (Wierzbanowa); 324. przys. Wierzch Góry (Pasierbiec); 325. przys. Wierzchowina (Łososina Dolna); 326. g. Wierzchowska Góra (Wierzbanowa); 327. przys. Wilczakowa (Tenczyn); 328. dol. Wilczy Rynek; 329. g. Wiśnia (g. Łopień); 330. g. Witów (Niedźwiedź); 331. przys. Wola Brzeziańska (Brezna); 332. przys. Wójciczki (Kamienica); 333. przys. Wójcikówka (Lubień); 334. g. Wróble (Łętowe); 335. przys. Wróble (Łostówka); 336. g. Wysoki Dzielec (Limanowa); 337. pol. Wyśnikówka (g. Mogielica); 338. przys. Zagórze (Zawadka); 339. przys. Zagórze (Męcina); 340. Za Kicznią (grzbiet g. Modyń); 341. przys. Zalesie (Zawadka); 342. przys. Załpa (Młynne); 343. przys. Załpa Górna (Młynne); 344. pot. Załpeński Potok (Młynne); 345. g. Zamczysko lub Białowodzka Góra (Białowoda); 346. g. Zapowiednica (Zalesie); 347. przys. Zarabie (Mszana Dolna); 348. przys. Zarębie (Mszana Dolna); 349. przys. Zarębki (Mszana Dolna); 350. przys. Zarębki (Siekierczyna); 351. przys. Zaświercze (Tymbark); 352. pot. Zawada (Łukowica); 353. Zawadka blisko Białowody; 354. przys. Zawady (Jurków); 355. Zbludza k. Kamienicy; 356. pot. Zbludza (Zbludza); 357. g. Zbludzkie Wierchy (Szczawa); 358. g. Zęzów (Tymbark); 359. Żmiąca; 360. pol. Żmiąca (między g. Sałasz i g. Jaworze); 361. dol. Żmiącej (Żmiąca). 


\section{Wykaz gatunków}

Lista zawiera 342 gatunki porostów ułożone alfabetycznie i opisane następująco: nazwa gatunku, synonim, siedlisko, liczba stanowisk i ich wykaz wraz z wysokością nad poziom morza $[870=870 \mathrm{~m}$ n.p.m.]; w nawiasach podano nazwę gminy, miejscowości lub góry, dla ułatwienia lokalizacji niektórych stanowisk.

\section{Absconditella lignicola Vězda \& Pišút - Czoła murszejących pniaków świer-} kowych.

3 stan. g. Lubogoszcz 870; g. Wróble 665; Bednarki 515.

Acarospora fuscata (Schrad.) Th. Fr. - Piaskowce (stosy kamieni, luźne murki, kamienie, skałki); miejsca suche i widne.

107 stan. pot. Śmigawka 510; g. Luboń Mały 870; g. Cymbałowa 570; Kubińcowa 420; Karpierzowa 720; g. Mała Góra 695; Michalaki 640; Dobrzany 645; Potok 420; Kozówka 680; g. Bydłoniowa 430, 640; poniżej lasu Mocarze 500; pot. Szarków 390; Groty 500; Ciże 410; Bołdony 565; g. Gródek 500; Sowy 605, 640; g. Lubogoszcz 925, 965; Filipiaki 630; g. Kocia Górka 610; Krzynów 615; g. Spyrkowa 715; g. Groń Herby 700; g. Witów 650, 710; Ciastonie 710; Sutory 470; g. Ogorzała 770, 800; Muszyny 545; g. Czarny Dział 640; H. Ćwilin 1010, 1060; g. Śnieżnica 775, 790; pot. Rosochaniec 625; g. Kobylica 880; pol. Łuki 1000, 1015; Przysłopek 870; Bruski 600; Polana Skalne 1050; g. Krzysztonów 1005; pol. Kozice 860; pol. Jaworze 945; g. Łopień 780; g. Mogielica 1165; H. Mogielica 1060, 1150 g. Styr 660 Zagórze 570 g. Hajdowska Góra 800; Czarna Rzeka 630; g. Hala 910; g. Turnia 565; g. Zęsów 685; Tymbark 645; Bulandy 500; Kurzejówka 515; g. Bystra Góra 660; g. Pasierbiecka Góra 730; Wierzch Góry 700; H. Modyń 880, 1015; Młynne 740; g. Ostra 865, 870; g. Byniowa 665; g. Jasieńczyk 810, 830, 860; g. Golców 730; g. Szkielek 720, 740, 745, 750; g. Sikorzec 800; g. Wysoki Dzielec 680; Kęcina 645; g. Pępówka 725, 750; Sarczyn 555; pol. Kuklacz 645; Jaworzna 640, 660; Na Korabiu 705; pot. Zawada 470; Na Padole 700; g. Sałasz 875; pot. Kamionka Mała 400; pol. Żmiąca 865; Na Kolonii 680, 740, 790; Dobrocierz 500; Kobyłczyna 630; Granica 715; Podlesie 555; g. Babia Góra 685; Chełm 745; g. Chełm 710, 770; Klenie 625.

A. glaucocarpa (Ach.) Koerb. - Wapniste piaskowce; miejsca dość cieniste. 2 stan. Bruski 630; g. Hala 910.

A. heppii (Naeg. ex Hepp) Naeg. in Koerb. - Głazy piaskowcowe nad potokami i rzekami.

2 stan. Zarabie 370; Piekiełko 375.

A. insolata H. Magn. - Bezwapienne piaskowce głównie nad brzegami rzek i potoków; miejsca suche i widne.

3 stan. pot. Szarków 390; Piekiełko 390; pot. Suchy 390.

A. macrospora (Hepp) Massal. ex Bagl. - Piaskowce o dużej zawartości węglanu wapnia; miejsca widne i suche.

3 stan. pot. Załpeński Potok 415; g. Zamczysko (Białowodzka Góra) 480, 540.

A. umbilicata Bagl. - Bezwapienne piaskowce, rzadziej mury piaskowcowe.

4 stan. Ciże 410; pot. Kamionka Mała 360; pot. Załpeński Potok 415; Piekiełko 375.

A. veronensis Massal. - Bezwapienne piaskowce (kamieńce nad rzekami i potokami, stosy kamieni); miejsca suche i widne.

25 stan. Michalaki 635; Kiece 550; Zarębie 370; g. Bydłoniowa 430; g. Kotelnica 745; Sowy 605; g. Spyrkowa 715; Na Witów 680; g. Krzysztonów 1005; pol. Jaworze 945; Tokarzówka 625; Zagórze 570; g. Tokoń 825; Piekiełko 375; Kozłówka 450; g. Golców 730; Jeżowa Woda 865; g. Szkiełek 740; Rozpite 475; Ogrojec 615; g. Pępówka 725; g. Sałasz 845; pot. Zawada 470; Dobrocierz 500; pot. Suchy 390. 
Acrocordia gemmata (Ach.) Massal. - Gładka kora drzew liściastych.

2 stan. pot. Rozpracki Potok 340; poniżej g. Zamczysko 325.

Amandinea punctata (Hoffm.) Coppins \& Scheideg. [= Buellia punctata (Hoffm.) Massal., B. stigmatea Koerb.] - Kora drzew liściastych, niekiedy murszejące drewno oraz bezwapienne piaskowce - drobne kamienie; miejsca widne i suche.

43 stan. Kubińcowa 395; Zarębki 370; Groty 500; Antosy 485; Myszoglądy 455; Janie 440; Kaima 555; Folwark 500; Zawady 520; Rola 480; m. przys. Rola a g. Łopień 510; Pietoniówka 455; Zaświercze 635; Kuźle 505; Bednarki 470; Podlesie 420; Rupniów 400; Dwór nad Łososiną 385; g. Tokoń 845; Wójciczki 435; Stara Karczma 450; Paryż 575; Byniowa 650; Moczarki 405; Stara Wieś 460; Ogrelówka 450; Załpa 330, 375; Kęcina 645; Mordarka 450; Potoki 550; dol. Roztoka 610; Pod Rębiskiem 580; dol. Rozdziele 325; pot. Zawada 510; Łukowica 445; Na Padole 700; Kobyłczyna Niżna 350; Wola Brzezińska 530; g. Soślina 510; pot. Suchy 390; Sadowa 390; Klęczany 295.

Anema decipiens (Massal.) Forss. - Skały piaskowcowe o bardzo dużej zawartości węglanu wapnia, np. strome osuwiska nad rzekami; miejsca bardzo widne i suche.

1 stan. Sadowa 285.

Arthonia lapidicola (Tayl.) Branth \& Rostr. - Silnie wapniste piaskowce, w miejscach widnych lub nieco zacienionych, np. nad potokami oraz rzekami, rzadko na mostkach przy torach kolejowych.

6 stan. Zarabie 370; Lemirze 385; Węglarka 380; Piekiełko 375; pot. Mroczkówki 380; Pisarzowa 445. lasach.

A. mediella Nyl. - Kora starych drzew iglastych i liściastych w naturalnych 3 stan. g. Luboń Wielki 985; g. Mogielica 900; g. Tokoń 845.

A. punctiformis Ach. - Kora drzew liściastych o gładkiej powierzchni, np. na młodych dębach.

1 stan. Zarębki 550 .

A. radiata (Pers.) Ach. - Gładka kora drzew liściastych, zwykle w naturalnych lasach.

11 stan. m. g. Mała Góra a g. Szczebel 885; Łąki 840; Kaima 560; Bruski 720; Białe 610; g. Mogielica 1060; Kobyłczyna Niżna 310; g. Modyń 915; Na Padole 515; Poddąbrowie 520; Zamczysko 530.

A. vinosa Leight. $[=A$. lurida auct. $]$ - Kora starych buków w naturalnych drzewostanach.

3 stan. Bruski 720; S ramię g. Łopień 900; g. Mogielica 1150.

Arthorhaphis citrinella (Ach.) Poelt [= Bacidia flavovirescens (Dicks.) Anzi] Gliniasta gleba, gleba wśród luźnych murków piaskowcowych nad źródłami; miejsca dość cieniste.

2 stan. H. Ćwilin 1010; Tokarzówka 655.

Arthothelium ruanum (Massal.) Koerb. [= A. ruanideum (Nyl.) Massal.] Kora młodszych drzew liściastych i leszczyny.

2 stan. Białe 610; poniżej g. Zamczysko 300.

Aspicilia caesiocinerea (Nyl. ex Malbr.) Arnold [= Lecanora caesiocinerea Nyl. ex Malbr.] Stosy bezwapiennych kamieni piaskowcowych; miejsca widne i suche.

3 stan. H. Ćwilin 1060; Jeżowa Woda 865; g. Szkiełek 740. 
A. calcarea (L.) Mudd [= Lecanora calcarea (L.) Sommerf.] Silnie wapniste skałki piaskowcowe; suche i widne miejsca.

7 stan. Niedźwiedź 475; Bulandy 500; Kozłowka 450; pot. Suchy 420; pot. Brzeźna 435; g. Zamczysko 465,540 .

A. cinerea (L.) Koerb. [= Lecanora cinerea (L.) Sommerf.] - Bezwapienne, suche i oświetlone piaskowce (skałki, głazy).

5 stan. g. Turnia 520, 565; Bulandy 500; Kurzejówka 515; g. Bystra Góra 660.

A. contorta (Hoffm.) Krempelh. [= Lecanora contorta (Hoffm.) Stnr.] - Wapienie i wapniste piaskowce; miejsca suche $\mathrm{i}$ widne.

2 stan. Gronoszowa 410; Fudaleje 570.

A. c. subsp. hoffmaniana Ekman \& Fröberg in Fröberg [= Lecanora hoffmanii auct.] - Silnie wapniste piaskowce (skałki, głazy).

7 stan. poniżej g. Bydłoniowa 430; Niedźwiedź 475; Sadowa 285; Zawadka 605; g. Zamczysko 465, 480,540 .

A. cf. farinosa (Flk.) Arnold [= Lecanora farinosa (Flk.) Nyl.] - Silnie wapniste osuwiska nad brzegami rzek; miejsca bardzo nasłonecznine i suche; w stanie płonnym.

1 stan. Sadowa 285.

A. insolata (H. Magn.) Hav. [= Lecanora insolata H. Magn.] - Bezwapienne piaskowce (skałki, gołoborza).

2 stan. pot. Rosochaniec 575; g. Turnia 565

A. laevata (Ach.) Arnold [=Lecanora laevata (Ach.) Nyl.] - Bezwapienne piaskowce (skałki, stosy kamieni, luźne murki, głazy); miejsca suche i widne.

15 stan. g. Lubogoszcz 925, 965; przeł. m. Groń Herby a Wierzchowską Górą 700; Do Uboczy 750; g. Kobylica 880; pot. Rosochaniec 575; g. Łopień 780; pot. Szczawa 560; Bulandy 500; Młynne 740; Pod Modyniem 880; Jeżowa Woda 865; g. Sikorzec 800; Sarczyn 555; Na Padole 700.

A. simoënsis R̈̈. [= Lecanora simoënsis (Räs.) A. Zahlbr., L. bahusiensis $\mathrm{H}$. Magn.] - Bezwapienne piaskowce (skałki, gołoborza, głazy, stosy kamieni); miejsca widne $\mathrm{i}$ suche; zwykle w stanie płonnym.

15 stan. pot. Śmigawka (apotecja) 510; g. Mała Góra 695; Potok 420; poniżej g. Bydłoniowa 430; g. Wierzbanowska 710; podnóże g. Turnia 520; Kuźle 505; Bulandy 500; g. Bystra Góra 660; Kurzejówka 515; g. Jasieńczyk 810; Sarczyn 555; Jaworzna 660, 675; g. Szkiełek (apotecja) 720.

Bacidia bagliettoana (Massal. \& De Not. in Massal.) Jatta $[=$ B. muscorum (Sw.) Mudd] - Obumierające mchy naskalne.

1 stan. Ciże 410.

B. globulosa (Flk.) Hafellner \& V. Wirth [= Catillaria globulosa (Flk.) Th. Fr.] - Kora starych buków.

4 stan. g. Śnieżnica 930; g. Jasień 1050; g. Łopień 885; g. Mogielica 1075.

B. rubella (Hoffm.) Massal. $[=B$. luteola '(Ach.) Mudd' $]$ - Kora drzew liściatych, zwłaszcza na omszałych pniach.

3 stan. Moskałowa 420; g. Mogielica 1150; Bednarki 470.

B. viridula Erichs. - Kora starych buków w naturalnych drzewostanach.

1 stan. pot. Mogielica 725 .

Bacidina inundata (Fr.) Vězda [ = Bacidia inundata (Fr.) Koerb. $]$ - Bezwapienne głazy i kamienie piaskowcowe okresowo zwilżane wodą w łożyskach strug, potoków i rzek. 
12 stan. Moskałowa 420; Las Luboński 605; pot. Adamczyków Potok 400; pot. Antosów 540; pot. Do Uboczy 760; poniżej Polany Skalnej 1000; g. Mogielica 1030; pot. Rybny Potok 685; nad Czarną Rzeką 700; Piekiełko 375; Potoki 580; pot. Na Padole 515.

B. phacodes (Koerb.) Vězda [= Bacidia phacodes Koerb.] - Stare murszejące drewno na czołach pniaków, rzadziej kora żywych drzew, np. na sosnach.

41 stan. g. Luboń Wielki 845, 920; g. Cymbałowa 540; Imka 510; g. Kotelnica 665; pot. Dawce 550; Dymały 550; m. Kasiną Wielką a g. Dzielec 600; g. Ogorzała 800; pot. Do Uboczy 760; g. Cyrki 640; g. Ćwilin 1020; Pod Śnieżnicą 590; pol. Pieżgula 1000; g. Krzysztonów 985; g. Łopień 900; g. Świnia Góra 560; Zalesie 550; g. Kostrza 640; Bednarki 545; g. Styr 640; pol. Brogi 840; g. Zapowiednica 820; g. Tokoń 925; Przysłop 775; g. Modyń 1025; Młynne 740; powyżej gajówki Na Górze 640; g. Jasieńczyk 860; Na Jaworzu 720; g. Kuklacz 675; Łyżka 765; Na Korabiu 705; Szałas 845; g. Pępówka 670; Na Kolonii 740; powyżej przys. Na Górach 715; g. Babia Góra 685; pot. Brzeźna 455; g. Soślina 565; Poddąbrowie 520.

Baeomyces rufus (Huds.) Rebent. - Bezwapienne piaskowce (skałki, głazy, kamienie) albo gliniasta gleba; miejsca nieco cieniste.

54 stan. g. Luboń Mały 780; pot. Adamczyków 760; Nowy Dwór 455; Łabuzy 500; pot. Szarków 390; g. Adamczykowa 560; g. Lubogoszcz 670, 925, 950, 965; g. Kocia Górka 575; Krzynów 615; g. Witów 710; Kasina Wielka 645; Sępki 520; Muszyny 545; g. Ćwilin 1000; g. Śnieżnica 970; pot. Jamne 725; g. Jasień 1030; Łęczyska 560; g. Łopień 780, 800; Chyszówki 580; powyżej pol. Stuse 890; Tokarzówka 710; Zalesie 550; pot. Rybny Potok 650; g. Mogielica 850, 970, 1060; m. g. Wiśnia a g. Rydznik 880; Czarna Rzeka 700; pot. Szczawa 560; Stara Karczma 595; g. Modyń 860, 1015; pot. Byniowa 500; Pod Modyniem 880; dol. Wilczy Rynek 405; Granica 580; Podokowaniec 660; g. Okowaniec 790; pot. Załpeński Potok 380; dol. Roztoka 610; Rozpite 475; m. Kopciówką a Laskową 725; Szałas 650; dol. Kamionki Małej 400; Klenie 510; pot. Brzeźna 455; g. Soślina 485; pot. Suchy 380; Kobyłczyna Niżna 335; g. Zamczysko 465.

Biatora efflorescens (Hedl.) Erichs. [ = Lecidea efflorescens (Hedl.) Vain.] - Kora starych buków, rzadko jodeł w naturalnych lasach; zwykle w stanie płonnym. 12 stan. g. Luboń Wielki 985; g. Śnieżnica 970; g. Krzysztonów 985, 1005; g. Łopień 840; g. Mogielica 1040, 1060, 1150; pot. Mogielica 765; g. Modyń 955, 1025; g. Jaworze 915.

Bryophagus gloeocapsa Nitschke \& Arnold [= Gyalecta gloeocapsa (Nitschke \& Arnold) A. Zahlbr., Gloeolecta bryophaga (Koerb. ex Arnold) Vězda] - Obumierające mchy naziemne albo naga gliniasta gleba, często obok dróg i ścieżek leśnych; miejsca cieniste i umiarkowanie wilgotne.

13 stan. g. Luboń Mały 590; g. Cymbałowa 540; poniżej g. Mały Groń 590; pot. Szarków 390; g. Lubogoszcz 855; Sępki 520; g. Ćwilin 670, 720; Łąki 840; powyżej pol. Folwarczna 900; powyżej przys. Bruski 670; pot. Rybny Potok 560; Kunówka 610.

Bryoria bicolor (Ehrh.) Brodo \& Hawksw. [= Alectoria bicolor (Ehrh.) Nyl.]

- Kora starych świerków w naturalnych lasach dolnoreglowych.

1 stan. Mogielica 1160.

B. crispa (Mot.) Bystr. [ = Alectoria crispa Mot.] - Kora drzew liściastych albo iglastych.

2 stan. poniżej g. Mogielica 835; Zagórze 570.

B. positiva (Gyeln.) Bystr. [=Alectoria positiva (Gyeln.) Mot.] - Kora drzew iglastych oraz liściastych (brzozy).

4 stan. pot. Luboński Potok 540; Imka 510; pol. Wyśnikówka 1100; g. Kudłacz 670.

Buellia aethalea (Ach.) Th. Fr. - Bezwapienne piaskowce (stosy kamieni); miejsca suche i widne.

1 stan. Jeżowa Woda 865. 
B. disciformis (Fr.) Mudd - Kora starych jaworów.
1 stan. Potoki 550.

B. griseovirens (Turn et Borr ex Sm.) Almb. $[=$ Diplotomma betulinum (Hepp) Arnold] - Kora drzew liściastych; głównie w stanie płonnym.

6 stan. Las Luboński 605; pot. Kozieniec 520; Dudziki 490; Węglarnia 475; pot. Szczawa 560; Potoki 550 .

B. leptocline (Flot.) Massal. - Bezwapienne piaskowce (stosy kamieni); miejsca suche i widne.

1 stan. Jeżowa Woda 865.

B. ocellata (Flot.) Koerb. [=B. verruculosa auct.] - Bezwapienne piaskowce (skałki, stosy kamieni); miejsca widne i suche.

8 stan. pot. Śmigawka 510; Bołdony 565; Kurzejówka 515; Kozłówka 450; Wierzch Góry 700; Jeżowa Woda 865; g. Pępówka 725; Na Korabiu 705.

B. schaereri De Not. - Kora drzew iglastych (jodły).

1 stan. poniżej g. Zamczysko 365.

Calicium abietinum Pers. - Murszejące drewno pniaków iglastych w naturalnych lasach.

1 stan. g. Mogielica 1165.

Caloplaca cerina (Ehrh. ex Hedw.) Th. Fr. - Kora starych, omszałych buków rosnących samotnie.

1 stan. g. Mogielica 1150.

C. cirrochroa (Ach.) Th. Fr. - Silnie wapniste, pionowe skały piaskowcowe. 1 stan. Ciże 410.

C. citrina (Hoffm.) Th. Fr. - Betonowe podłoże (mostki, omurowania potoków, mury cmentarne), rzadziej skałki piaskowcowe.

8 stan. Gronoszowa 410; Niedźwiedź 475; Stecki 435; Rola 480; Kozłówka 450; g. Golców 745; dol. Rozdziele 360; pot. Zawada 470.

C. decipiens (Arnold) Blomb. \& Forssell - Betonowe podłoże (słupki, mury, mosty, omurowania potoków).

5 stan. Limanowa 405; Laskowa 330; pot. Zawada 470; Pisarzowa 475; Męcina 380.

C. dolomiticola (Hue) A. Zahlbr. - Silnie wapniste piaskowce; miejsca widne i suche.

6 stan. Potok 420; Zarębie 370; Lemirze 385; Fudaleje 575; Kurzejówka 515; Strzeszyce 305.

C. flavovirescens (Wulf.) DT. \& Sarnth. - Wapniste piaskowce (skałki, głazy); miejsca suche i widne.

11 stan. Potok 420; Kuce 390; g. Bydłoniowa 430; g. Gródek 500; Niedźwiedź 475; podnóże g. Turnia 560; pot. Szczawa 560; g. Bystra 660; Kozłówka 450; Sadowa 285; g. Zamczysko 465.

C. holocarpa (Hoffm. ex Ach.) Wade [ = C. lithophila H. Magn., C. pyracea (Ach.) Th. Fr.] - Bezwapienne lub wapniste piaskowce (skałki, głazy nad potokami, stosy kamieni), niekiedy podłoże betonowe, kora drzew liściastych i drewniane poręcze mostów, parkany, ogrodzenia.

45 stan. pot. Śmigawka 510; Kubińcowa 420; Janówka 460; pot. Bajtków Potok 435; poniżej g. Bydłoniowa 430; Bołdony 565; g. Kotelnica 745; g. Gródek 490; Na Witów 680; g. Witów 650; m. Kaletami a Putami 495; Las Puciaki 500; Dudziki 500; H. Ćwilin 1010; Tokarzówka 695; Czarna Rzeka 630; u podnóża g. Turnia 560; m. Bulandami a Chlipałami 500; g. Bystra Góra 660; m. Wierchami a Ślagami 760; Piekło 375; pot. Mroczkówki 380; g. Golców 745; Jeżowa Woda 865; g. Szkiełek 740; Laskowa 330; m. Mordarką i Limanową 450; m. g. Kudłacz a Zarębkami 575; Potoki 550; Ogrojec 615; pot. Zawada 470; dol. Jaworznej 400; Na Padole 700; Przyszowa 435; Łukowica 510; dol. Kamionki 
Małej 360, 400; pot. Zawada 470; Pisarzowa 445; Podlesie 555; g. Babia Góra 720; pot. Suchy 420; g. Chełm 750; pot. Brzeźna 435; Klęczany 290.

C. lactea (Massal.) A. Zahlbr. - Silnie wapniste piaskowce miejsca suche i nasłonecznione.

2 stan. Kiece 550; poniżej g. Bydłoniowa 430.

C. teicholyta (Ach.) Stnr. [=C. arenaria auct.] - Silnie wapniste osuwisko nad rzeką; miejsca suche i słoneczne.

2 stan. Pisarzowa 475; Sadowa 285.

Candelaria concolor (Dicks.) Stein - Kora drzew liściastych, zwłaszcza rosnących pojedynczo albo przydrożnych.

40 stan. Pasiowa 425; Kubińcowa 395; Wilczakowa 510; Karpieńcowa 545; Antosy 485; Myszoglądy 455; Kopytki 500; Kuczaje 545; Płoszczyce 600; Rubisie 525; Rola 480; Chyszówki 580; Pietoniówka 445; Kuźle 505; Rupniów 400; Dwór nad Łososiną 385; m. Bulandami a Chlipałami 500; Zbludza 490; Stara Karczma 495; Paryż 575; Mikołajczyki 415; Byniowa 400, 425; Stara Wieś 460; Ogrelówka 450; Limanowa 455; Załpa 330; m. Mordarką i Limanową 450; Rozpicki Potok 340; Szarówka 680; Kunówka 610; Zawada 510, 540; Łukowica 445; Świdnik 390; Na Kolonii 680; Podgórze 550; Brzeźna 465; Sadowa 415; Zawadka 600.

Candelariella aurella (Hoffm.) A. Zahlbr. - Wapienie lub wapniste piaskowce lub obiekty murowane i betonowe, najczęściej obok dróg; miejsca suche i widne. 24 stan. Kubińcowa 420; Potok 420; Kuce 390; pot. Szarków 390; pot. Bajtków Potok 435; Gronoszowa 415; Las Puciaki 500; Kopytki 505; Rubisie 625; Tokarzówka 695; Czarna Rzeka 630; podnóże g. Turnia 560; Piekiełko 375; pot. Mroczkówki 380; Kozłówka 450; g. Golców 745; Potoki 420; dol. Kamionki Małej 360; Pisarzowa 445; Pagórek 275; Męcina 380; Sadowa 285; pot. Brzeźna 435; g. Zamczysko 480.

C. vitellina (Hoffm.) Müll. Arg. - Bezwapienne lub lekko wapniste piaskowce, także beton, sporadycznie nagie drewno.

113 stan. pot. Śmigawka 510; g. Kotelnica 745; g. Cymbałowa 570; Kubińcowa 420; pol. poniżej g. Mały Groń 575; Karpierzowa 720; pot. Miedziany 700; g. Mała Góra 695; Michalaki 635; Kiece 550; Dobrzany 645; Potok 420; Kozówka 580; Groty 500; m. Groń Herby i Wierzchowską Górą 700; g. Lubogoszcz 925 , 965; Krzynów 615; g. Spyrkowa 715; Ciastonie 710; g. Witów 650, 710; Las Praciaki 500; g. Czarny Dział 640; Farganusy 465; Sutory 470; Dawce 580; g. Ogorzała 775, 800; Muszyny 545; g. Śnieżnica 775, 1005; pot. Do Uboczy 750; H. Ćwilin 1010, 1060; pot. Rosochaniec 575, 625; g. Kobylica 880; Rubisie 625; pol. Łuki 1015; Przysłopek 870; Smolenie 650; Fudaleje 575; g. Krzysztonów 1005; Rola 480; pol. Przysłopek 910; pol. Wyśnikówka 1100; g. Mogielica 1165; g. Cyrla 690; g. Grójec 570; Styr 660; g. Hajdowska Góra 800; Czarna Rzeka 600, 630; g. Hala 910; g. Turnia 520; Kuźle 505; g. Zesów 635; Tymbark 645; g. Bystra Góra 660; Kurzejówka 515; Węglarka 380; m. Wierchami i Ślagami 760; g. Tokoń 825; g. Pasierbiecka Góra 730; Wierzch Góry 700; H. Modyń 1015; Młynne 740; g. Kamionna 780; g. Ostra 870; Pod Modyniem 880; g. Byniowa 665; g. Jasieńczyk 810, 860; g. Golców 730; Jeżowa Woda 860; g. Szkiełek 740, 745, 750; g. Sikorzec 800; g. Dzielec 680; Kęcina 680; Rozpite 475; Sarczyn 555; Ogrojec 615; g. Pępówka 725, 750; Jaworzna 640, 660; Na Korabiu 705; pot. Zawada 470; Chumowa 570; Na Padole 700; g. Sałasz 875; dol. Kamionki Małej 400; Przyszowa 435; Na Kolonii 680, 790; g. Jaworze 855; Kobyłczyna 630, 675; Granica 715; Podlesie 555; g. Babia Góra 685; pot. Suchy 420; g. Chełm 745, 750, 760, 770; Klenie 625, 660; Zawadka 605; g. Zamczysko 480.

C. xanthostigma (Ach.) Lett. - Kora drzew liściastych, głównie przydrożnych i samotnie rosnących, rzadko buki.

79 stan. Pasiowa 425; Kubińcowa 395; Krętowa 440; Luboński Potok 495; Wilczakowa 510; Janówka 460; Biedaki 470; Kiece 550; m. Bajkami i Kołkówką 450; Potok 400; Szarków 400; pot. Bajtków Potok 435; Szynaliki 405; Myszoglądy 455; Janie 440; Dudziki 500; Kopytki 500; Muszyny 545; Płoszczyce 600; Dwór 385; Szczypty 650; Kaima 560; Zawady 520; Dobra 470; Rola 480; Węglarnia 475; Pietoniówka 445; Sorysz 740; Kuźle 505; Bednarki 470; Podlesie 420; Tymbark 645; Rupniów 400; Stara Karczma 450; g. Modyń 1025; Paryż 575; pot. Byniowa 400; Moczarki 405; Stara Wieś 460; Kurczaby 500; 
Podokowaniec 720; Załpa 330; Kęcina 575; Potoki 550, 585; Łąki 570; Na Paryjach 540; Rozpite 340; Kunówka 590; Pod Rębiskiem 580; Mordarka 475; Szarówka 680; Ogrojec 640; dol. Rozdziele 335; Na Korabiu 705; pot. Zawada 540, 570; Łukowica 445, 510; pot. Jaworzna 385; Przyszowa 440; Świdnik 930; dol. Żmiącej 385, 430; g. Jaworze 865; m. g. Jaworze a g. Wielka Góra 675; Krosna 300, 335, 350; Kobyłczyna Niżna 350; pot. Suchy 480; Brzeźna 430, 465; Burdak 470; Sośniny 350; Litacz 610; Wola Brzezińska 530; Sadowa 425; Zawadka 600.

Catapyrenium lachneum (Ach.) R. Sant. [= Dermatocarpon lachneum (Ach.) A. L. Sm.] - Silnie wapniste piaskowce w miejscach suchych i widnych; na warstewce humusu.

1 stan. Niedźwiedź 475.

Catillaria lenticularis (Ach.) Th. Fr. - Wapniste skałki piaskowcowe; miejsca nieco cieniste.

1 stan. g. Lubogoszcz 925.

Cetraria islandica (L.) Ach. - Gliniasta gleba na nieużytkach; miejsca suche i widne.

46 stan. m. g. Luboń Mały a Krzysiami 875; poniżej g. Mały Groń 590; g. Mały Groń 720; g. Mała Góra 695; Dobrzany 665; Kozówka 615; Na Snoze 465; m. g. Adamczykowa a Piwowarami 560; Ciastonie 700; Rusiny 580; Pod Gronią 615; Kordówka 630; g. Ogorzała 775; g. Śnieżnica 930; g. Ćwilin 1020; g. Wróble 665; m. Łąkami a g. Cyrki 740, 840; g. Kobylica 880; Piechówka 570; Pod Górą 615; g. Jasień 920; m. g. Myszyca a Przysłopkiem 815; pol. Pieżgula 1000; pol. Janiowa 820; pol. Kozice 860; g. Mogielica 820, 980; Tokarzówka 710; pol. Wyśnikówka 1095; Bukowina 790; m. Wierchami a Ślagami 760; Okrąg 565; m. Burdami a Byniową 620; g. Jasieńczyk 850; Jeżowa Woda 870; Jaworze 830; Cecygówka 735; g. Łyżka 780; g. Pępówka 770; g. Szkiełek 750; Na Padole 700; g. Kopiec 570; Chełm 745; g. Babia Góra 720; g. Łysa Góra 560.

Cetrelia cetrarioides (Duby) W. Culb. \& C. Culb. [ = Parmelia cetrarioides (Duby) Nyl.] - Kora starych buków, zwykle na skraju naturalnych lasów.

9 stan. g. Śnieżnica 970; g. Krzysztonów 985, 1005; g. Mogielica 900, 1030, 1040; g. Hala 905; g. Modyń 985, 1025.

Chaenotheca brunneola (Ach.) Müll. Arg. - Butwiejące pniaki iglaste w miejscach cienistych, głównie w naturalnych lasach.

1 stan. g. Ćwilin 1020.

Ch. chrysocephala (Turn. ex Ach.) Th. Fr. - Kora drzew iglastych, zwykle w naturalnych lasach.

9 stan. Las Luboński 710; pot. Szarków 390; g. Mogielica 1000, 1165; polanki poniżej g. Cyrla 690; pot. Suchy 445, 470; pot. Brzeźna 480; poniżej g. Zamczysko 300.

Ch. ferruginea (Turn. \& Borrer) Mig. [= C. melanophaea (Ach.) Zw.] Kora drzew iglastych, często rosnących nad potokami.

8 stan. Luboński Potok 520; pot. Adamczyków 580; pot. Szarków 390; Na Snoze 465; Sarczyn 555; pot. Suchy 445, 470; pot. Brzeźna 480 .

Ch. furfuracea (L.) Tibell [= Coniocybe furfuracea $(\mathrm{L}$.$) Ach.] - Jamki między$ korzeniami drzew iglastych, rzadziej liściastych albo butwiejące drewno, niekiedy jamki wśród skał piaskowcowych; często w stanie płonnym.

9 stan. Na Snoze 465; g. Lubogoszcz 950; Budacze 790; g. Śnieżnica 970; Łąki 840; Rubisie 685; g. Łopień 850; Łukowica 510; pot. Brzeźna 480.

Ch. stemonea (Ach.) Mll. Arg. - Jamki między korzeniami drzew iglastych. 1 stan. Łąki 840.

Ch. xyloxena Nádv. [ = C. nudiuscula (Schaer.) Nádv.] - Murszejące drewno pniaków iglastych; miejsca cieniste.

3 stan. g. Krzysztonów 950; g. Łopień 850; pot. Rybny Potok 650. 
Chromatochlamys muscorum (Fr.) Mayrh. \& Poelt [= Microglaena muscorum (Fr.) Th. Fr.] - Obumierające mchy naskalne; miejsca słoneczne. 1 stan. g. Bystra Góra 660.

Chrysothrix candelaris (L.) Laundon [= Lepraria candelaris (L.) Fr.] - Kora starych jodeł w naturalnych lasach.

2 stan. Łąki 840; pot. Rybny Potok 510.

Cladina arbuscula (Wallr.) Hale \& W. Culb. [= Cladonia sylvatica auct. $]$ - Gliniasta gleba na nieużytkach.

2 stan. podnóże g. Turnia 520; Tokarze 680.

C. ciliata Stirt. var. tenuis (Flk.) Ahti \& Lai [= Cladonia tenuis (Flk.) Harm.] - Gliniasta gleba na nieużytkach i między wrzosami.

10 stan. pot. Szarków 455; Na Snoze 465; g. Turnia 520; pot. Załpeński Potok 400; Rozpite 475; g. Pępówka 770; g. Szkiełek 740; Podpiekle 490; Brzeźna 480; g. Soślina 485.

C. mitis (Sandst.) Hustich [= Cladonia mitis Sandst.] - Gliniasta gleba wśród traw, wrzosów, jałowców, rzadko na czołach murszejących pniaków.

26 stan. Karpierzowa 720; Dobrzany 665; m. pot. Szarków a g. Okrągła 455; pol. Imka 535; Na Snoze 465; Przylasek 500; m. g. Adamczykowa a Piwowarami 560; g. Kotelnica 720; Ciastonie 700; Dawce 580; g. Ogorzała 775; g. Jasień 1060; g. Myszyca 865; pol. Wyśnikówka 1095; g. Mogielica 820; podnóże g. Turnia 520; g. Pasierbiecka Góra 765; g. Jasieńczyk 850; Jaworze 830; g. Kuklacz 650; g. Pępówka 770; g. Szkiełek 790; Na Padole 700; g. Komera 555; Brzeźna 480; g. Chełm 720.

C. rangiferina (L.) Nyl. [= Cladonia rangiferina (L.) Weber ex Wigg.] - Gleba wśród traw i borówek lub w borze sosnowym.

11 stan. g. Cymbałowa 540; g. Kamionka 585; Kordówka 640; g. Ćwilin 670; m. Zbludzkimi Wierchami a Bystrą Górą 730; Stara Karczma 615; g. Okowaniec 790; Rozpite 475; g. Pępówka 770; g. Szkiełek 740; g. Chełm 720 .

Cladonia bacillaris (Leight.) Arnold - Stopy pni sosen.

1 stan. pol. Imka 510.

C. botrytes (Hagen) Willd. - Czoła murszejących pniaków iglastych; widne miejsca.

2 stan. g. Ćwilin nad przys. Drągówka 670; g. Myszyca 865.

C. caespiticia (Pers.) Flk. - Gliniasta gleba na skarpach dróg leśnych albo na stromych zboczach nieco zacienionych, zwykle w stanie płonnym. Stanowiska gatunku przeoczone.

4 stan. Rozpite (apotecja) 475; dol. Krosnej 380; pot. Brzeźna 480; Kobyłczyna Niżna 335.

C. cariosa (Ach.) Spreng. - Gliniasta gleba na nieużytkach.

1 stan. m. Łąkami a g. Cyrki 830 .

C. cenotea (Ach.) Schaer. - Czoła pniaków albo gleba gliniasta.

2 stan. g. Myszyce 865; m. Zbludzkimi Wierchami a g. Bystrą Górą 730.

C. cervicornis (Ach.) Flot. subsp. verticillata (Hoffm.) Ahti - Gleba gliniasta na nieużytkach, wśród wrzosów.

15 stan. g. Mała Góra 695; Szewczyki 620; g. Bydłoniowa 645; Ciastonie 700; pot. Rosochaniec 615; pol. Folwarczna 900; Przysłopek 815; g. Jasień 1030; poniżej pol. Janiowa 800; g. Mogielica 820; g. Turnia 520; g. Pasierbiecka Góra 765; g. Golców 650; m. Kopciówką a Laskową 725; Dobrocierz 500.

C. chlorophaea (Flk. ex Sommerf.) Spreng. - Gliniasto-piaszczysta gleba, humus, między mchami, omszałe skały piaskowcowe, niekiedy stopy starych drzew.

80 stan. g. Luboń Mały 870; Krzysie 875; Luboński Potok 520, 560; pot. Miedziany 700; g. Mała Góra 695; g. Kamionka 585; Potok 420; g. Bydłoniowa 640; pot. Szarków 390; pot. Bajtków Potok 435; m. g. Adamczykowa a Piwowarami 560; pot. Głębowski 505; Przylasek 500; pot. Antosów 540; g. Kocia Górka 
610; Krzynów 615; m. g. Groń Herby a Wierzchowską Górą 700; m. Kasiną Wielką a g. Lubogoszcz 645; Janie 440; Dymasy 510; g. Ogorzała 775; Sępki 520; Wróble 580; g. Cyrki 640; pot. Do Uboczy 715; Udziele 480; m. Łąkami a Cyrkami 830; g. Śnieżnica 970; H. Ćwilin 1010; Chumowa 570; g. Jasień 920; m. g. Myszyca a Przysłopkiem 815; Tracze 750; podnóże g. Łopień 615; Rybny Potok 510, 650; g. Mogielica 820, 850; Kuce 390; g. Hale 910; g. Turnia 565; Nowy Dwór 455; m. Bulandami a Chlipałałami 500; Kozłówka 450; Stara Karczma 595; g. Modyń 915, 1025; pot. Byniowa 500, 545; Pod Modyniem 825; g. Jasieńczyk 810; Jaworze 830; Podokowaniec 720; Cecygówka 735; g. Stawiska 600; Załpeński Potok 380, 415; Rozpite 475; Kopciówka 715; Na Jaworzu 720; g. Łyżka 685; dol. Rozdziele 340; g. Pępówka 615, 750; dol. Jaworznej 350; g. Wielka Góra 730; Dobrocierz 500; Zagórze 570; Podpiekle 490; Kobyłczyna Wyżna 595; g. Kamere 555; pot. Suchy 380, 480; Drużków Pusty 450; Klenie 560; g. Soślina 560; m. Litaczem a Łysą Górą 570; g. Łysa Góra 535, 560.

C. coccifera (L.) Willd. - Gliniasta gleba.

2 stan. g. Hala 830; g. Turnia 520.

C. coniocraea (Flk.) Spreng. - Gliniasta gleba, humus, murszejące drewno (pniaki, kłody) oraz kora starych drzew u nasady pni, rzadziej podłoże skalne. 83 stan. g. Luboń Mały 780, 870; Krzysie 875; Luboński Potok 520; g. Mały Groń 720; Pod Szczebel 765; pot. Miedziany 700; g. Mała Góra 695, 830; Zarębie 480; Szewczyki 620; pot. Szarków 390; Groty 475; Kuce 435; m. g. Adamczykowa a Piwowarami 560, 580; pot. Antosów 540; Wierzbanowska Góra 720; g. Lubogoszcz 900, 925; m. Kasiną Wielką a g. Lubogoszcz 645; pot. Dawce 550, 580; Drągówka 670; pot. Wierzbanica 575; g. Śnieżnica 1005; Do Uboczy 760; Wróble 580; g. Ćwilin 1020, 1050; m. Łąkami a g. Cyrki 830; g. Śnieżnica 730; Przysłopek 815, 855; Smolenie 650; pol. Pieżgula 1000; Polana Skalne 1050; g. Myszyca 865; pol. Janiowa 820; Bruski 720; m. Dobrą a g. Łopień 530; Łęczyska 560; g. Łopień 780, 800; g. Krzysztonów 980, 985, 1005; Wyśnikówka 1100; g. Mogielica 820, 835, 850, 1040; pot. Rybny Potok 510; g. Styr 660; g. Hala 905; g. Tokoń 925; Nowy Dwór 455; Zbludzkie Wierchy 800; g. Modyń 1025; m. Przysłopem a Wierzyką 775; pot. Byniowa 545; Pod Modyniem 825; dol. Wilczy Rynek 405, 480; Jeżowa Woda 870; Podokowaniec 720; g. Stawiska 600; pot. Załpeński Potok 380; Kęcina 645; Łąki 570; Na Jaworzu 720; g. Łyżka 685; Rozpite 475, 485; g. Jaworze 915; Dobrocierz 500; dol. Krosnej 380; Podpiekle 490; Podlesie 555; Drużków Pusty 450; Klenie 510; g. Gwizdor 590; g. Soślina 565; pot. Suchy 445; Wierzchowina 460; g. Chełm 740; m. Litaczem a g. Łysa Góra 570; g. Łysa Góra 535; poniżej g. Zamczysko 300; g. Szcząb 425.

C. cornuta (L.) Hoffm. - Gliniasta gleba.

1 stan. g. Okowaniec 790.

C. deformis (L.) Hoffm. - Gliniasta gleba.

6 stan. Luboński Potok 560; m. pot. Szarków a g. Okrągła 455; m. g. Adamczykowa a Piwowarami 560; m. Kasiną Wielką a Lubogoszczem 645; Tokarze 680; g. Łysa Góra 560.

C. digitata (L.) Hoffm. - Butwiejące pniaki, stopy drzew iglastych, rzadziej liściastych; zwykle miejsca cieniste.

27 stan. Krzysie 700; Las Luboński 605; pot. Szarków 390; g. Lubogoszcz 960; pot. Do Uboczy 760; Wróble 665; g. Cyrki 640; g. Śnieżnica 960; g. Ćwilin 1020, 1025; Rubisie 655; pot. Jamne 725; Łęczyska 560; g. Łopień 800; g. Krzysztonów 985; pol. Wyśnikówka 1100; g. Mogielica 1040; Bukowina 790; g. Tokoń 880; dol. Wilczy Rynek 405; Moczarki 390; Tokarze 625; Dębina 580; Na Padole 515; Klenie 510; pot. Suchy 470; g. Szcząb 425.

C. fimbriata (L.) Fr. [=C major (Hagen) Sandst., C. minor (Hagen) Vain.] - Gliniasta gleba, rzadziej murszejące drewno pniaków lub stopy pni żywych drzew. 46 stan. g. Luboń Mały 710, 780; Krzysie 875; Luboński Potok 560, 585; g. Mały Groń 720; Pod Szczebel 765; Pot. Miedziany 700; g. Mała Góra 695; pot. Szarków 390; m. g. Adamczykowa a Piwowarami 560; g. Lubogoszcz 965; pot. Antosów 540; Sępki 520; pot. Wierzbanica 575; g. Śnieżnica 730; g. Ćwilin 1020; m. Łąkami a g. Cyrki 740; g. Kobylica 880; m. g. Myszyca a Przysłopkiem 815; Smolenie 650; g. Jasień 1030; pot. Rybny Potok 650; m. g. Wiśnia a g. Rydznik 880; g. Łopień 900; g. Mogielica 850; g. Hala 910; Nowy Dwór 455; dol. Wilczy Rynek 405; g. Golców 730; g. Sikorzec 780; g. Stawiska 600; Załpeński Potok 340; Kęcina 645; Rozpite 475; g. Łyżka 685, 780; g. Pępówka 615; g. 
Szkiełek 720; Podpiekle 490; g. Chełm 765; pot. Brzeźna 455, 480; Kobyłczyna Niżna 335; Klenie 625; g. Łysa Góra 535.

C. furcata (Huds.) Schrad. - Gliniasta gleba, nieużytki, wrzosowiska, drogi leśne. 82 stan. Luboński Potok 520, 560; g. Mały Groń 790; pot. Miedziany 700; m. pot. Szarków a g. Okrągła 455; Szewczyki 620; pot. Szarków 390; m. g. Adamczykowa a Piwowarami 560; Sowy 605; Przylasek 500; g. Lubogoszcz 670; Ciastonie 700; m. Kasiną Wielką a Lubogoszczem 645; Rusiny 580; g. Ogorzała 775; Drągówka 670; g. Hale 820; Wróble 580; g. Ćwilin 1025; Wróble 650; g. Cyrki 640; pot. Do Uboczy 715; m. Łąkami a g. Cyrki 830; g. Śnieżnica 730, 930; Przysłopek 815, 855; Smolenie 650; g. Jasień 1030; pol. Janiowa 820; pol. Wyśnikówka 1095; pot. Rybny Potok 560; g. Mogielica 820, 850; podnóże g. Turnia 520; g. Zbludzkie Wierchy 730; Stara Karczma 615; g. Okrąg 565; Burdy 620; pot. Byniowa 545; g. Jasieńczyk 850; dol. Wilczy Rynek 405; Ogrelówka 450; dol. Jabłoniec 445; Cecygówka 735; g. Golców 650; Jaworze 830; Podokowaniec 720; g. Sikorzec 800; Stawiska 600; g. Szklarka 500; Załpeński Potok 400; g. Kuklacz 650, 675, 770; g. Łyżka 685, 770, 780; Rosochodka 580; Jaworzna 640; Rozpite 485; Szałas 650; g. Pępkówka 615; Lasek 595; Dębina 580; dol. Jaworznej 350; g. Wielka Góra 730; Dobrocierz 500; Podpiekle 490; Podlesie 555; Kamere 555; pot. Brzeźna 435, 480; g. Soślina 485, 560; g. Babia Góra 720; Klenie 625; m. Litaczem a Łysą Górą 560, 570; Sadowa 425; Poddąbrowie 520; g. Szcząb 485.

C. glauca Flk. - Gliniasta lub torfiasta gleba.

3 stan. m. g. Adamczykowa a Piwowarami 560; Drągówka 670; Tokarze 680.

C. gracilis (L.) Willd. - Gliniasta lub kamienista gleba.

5 stan. g. Turnia 520; g. Jasieńczyk 850; Jaworze 830; Podpiekle 490; g. Kamera 570.

C. macilenta Hoffm. - Murszejące drewno czołowych powierzchni pniaków. 5 stan. g. Mały Groń 720; Groty 475; g. Cyrki 640; g. Myszyca 865; Załpieński Potok 400.

C. ochrochlora Flk. - Butwiejące drewno (powalone pnie, kłody, pniaki).

7 stan. Luboński Potok 520; Groty 475; g. Kotelnica 665; Do Uboczy 760; g. Modyń 1025; Klenie 560; pot. Brzezna 455.

C. phyllophora Hoffm. [= C. degenerans (Flk.) Spreng.] - Gliniasta gleba. 9 stan. Luboński Potok 560; m. g. Adamczykowa a Piwowarami 560; Drągówka 670; g. Śnieżnica 730; Przysłopek 815; pot. Rybny Potok 530; Załpeński Potok 400; Dobrocierz 580; g. Kamera 570.

C. pleurota (Flk.) Schaer. - Gliniasta i torfiasta gleba, niekiedy warstewka gleby na stosach kamieni piaskowcowych.

47 stan. pot. Miedziany 700; g. Mała Góra 695; g. Kamionka 585; Kozówka 615; Piwowary 580; g. Gródek 490; Sowy 605; g. Lubogoszcz 670; g. Kocia Górka 610; Puciaki 500; g. Ogorzała 740; Pod Gronią 615; m. Myszycą a Przysłopkiem 815; pot. Do Uboczy 750; m. Łąkami a g. Cyrki 740, 830; pol. Folwarczna 860; g. Jasień 920; poniżej pol. Brogi 595; Stara Karczma 615; g. Kamionna 800; Pod Modyniem 880; g. Golców 650; g. Sikorzec 800; Cecygówka 735; Stawiska 600; g. Kuklacz 625; Tokarze 680; Sarczyn 555; dol. Rozdziele 340; Jaworzna 575, 640; g. Pępkówka 770; g. Szkiełek 750; Lasek 595; dol. Kamionki Małej 420; g. Jaworze 855; Dobrocierz 500; Kobyłczyna 630; Granica 715; Zagórze 540; Kobyłczyna Wyżna 595; Kamera 555; g. Chełm 745; pot. Suchy 390; Kobyłczyna Niżna 335; Wierzchowina 460.

C. pocillum (Ach.) Grognot - Wapnista gleba oraz mchy naziemne porastające silnie wapniste piaskowce.

6 stan. pot. Rosochaniec 575; Fudaleje 575; g. Turnia 560; g. Okrąg 565; pot. Gajduszowiec 475; pot. Suchy 420.

C. polycarpoides Nyl. [C. subcariosa auct.] - Gliniasta gleba na nieużytkach. 3 stan. Las Puciaki 500; pot. Rosochaniec 575; g. Hala 820.

C. pyxidata (L.) Hoffm. - Piaszczysta i gliniasta gleba, omszałe skały.

12 stan. Piwowary 580; g. Kocia Górka 610; Pod Granicą 615; m. Łąkami a Cyrkami 830; pot. Do Uboczy 715; g. Ćwilin 1060; Tokarze 680; Na Korabiu 685; Jaworzna 640; g. Szkiełek 720; Podlesie 555; pot. Suchy 420 . 
C. ramulosa (With.) Laundon $[=C$. pityrea (Flk.) Fr. $]$ - Gliniasta gleba. 1 stan. Cecygówka 735.

C. rangiformis Hoffm. - Gliniasto-kamienista gleba na nieużytkach; miejsca suche i słoneczne.

18 stan. Potok 420; m. pot. Szarków a g. Okrągła 455; Krzynów 615; Pod Gronią 615; Dawce 580; Kordówka 630; pot. Rosochaniec 575; Czarna Rzeka 630; Kozłówka 450; g. Okrąg 600; pot. Byniowa 500; g. Jasieńczyk 860; Cecygówka 735; Załpieński Potok 400; Tokarze 860; g. Pępkówka 710; pot. Suchy 480; g. Łysa Góra 560.

C. squamosa Hoffm. - Gliniasto-piaszczysta gleba oraz stopy drzew, niekiedy omszałe głazy piaskowcowe.

12 stan. Luboński Potok 560; m. pot. Szarków a g. Okrągła 455; g. Ogorzała 775; g. Ćwilin 1025; g. Jasień 1030; podnóże g. Łopień 560; g. Mogielica 1150, 1160; pot. Rybny Potok 530; Tokarze 680; g. Łyżka 685; Rozpite 485.

C. subulata (L.) Weber ex Wigg. [= C. cornutoradiata (Vain.) Zopf] - Gliniasta lub kamienista gleba, najczęściej na nieużytkach.

55 stan. Luboński Potok 520, 560; Pod Szczebel 765; g. Mała Góra 695, 770; g. Kamionka 585; Kiece 550; Łabuzy 500; Potok 420; pot. Szarków 390; Piwowary 580; pot. Antosów 540; g. Lubogoszcz 670; las Puciaki 500; g. Ogorzała 740; Zalesie 550; Drągówka 670; m. Wróblami a g. Ostra 650; pot. Do Uboczy 750; g. Cyrki 640; m. Łąkami a g. Cyrki 830; pol. Folwarczna 940; g. Jasień 920; m. g. Myszyca a Przysłopkiem 815; g. Myszyca 865; g.Lopień 780; pot. Rybny Potok 650; g. Mogielica 820, 850, 880; Czarna Rzeka 600; g. Hala 870, 910; podnóże g. Turnia 520; Nowy Dwór 455; Kozłówka 450; g. Okrąg 600; Pod Modyniem 880; dol. Wilczy Rynek 405; Podokowaniec 720; g. Szkiełek 740; Cecygówka 735; Tokarze 680; g. Łyżka 685, 780; g. Stawiska 600; dol. Rozdziele 340; Na Korabiu 685; g. Pępówka 615; dol. Jaworznej 350; Kobyłczyna 630; g. Chełm 750; Kalenie 625; m. Litaczem a g. Łysa Góra 570; g. Łysa Góra 560 .

C. symphycarpa (Flk.) Fr. - Gliniasto-wapnista gleba; miejsca suche i widne. 10 stan. g. Bydłoniowa 430; m. Ciżami a Podgródkiem 410; pot. Rosochaniec 575; m. Bulandami a Chlipałami 500; g. Okrąg 660; pot. Byniowa 545; Sarczyn 555; pot. Suchy 420; Kobyłczyna Niżna 335; pot. Brzeźna 435 .

C. turgida Hoffm. - Gliniasta gleba między jałowcami i trawami.

21 stan. g. Cymbałowa 540; pot. Miedziany 700; m. pot. Szarków a g. Okrągła 455; m. g. Adamczykowa a Piwowarami 560; g. Kotelnica 720; m. Kasiną Wielką a g. Lubogoszcz 645; Rusiny 580; Drągówka 670; g. Cyrki 640; H. Ćwilin 1010; Tracze 750; Tokarzówka 710; g. Mogielica 820; Cecygówka 735; g. Łyżka 780; g. Pępkówka 770; Dębina 580; g. Kopiec 570; g. Wielka Góra 730; Kobyłczyna Wyżnia 595; g. Babia Góra 720 .

Clauzadea monticola (Schaer.) Hafellner \& Bellem. [ = Lecidea monticola Schaer., L. ochracea Hepp ex Koerb.] - Wapniste piaskowce (skałki) oraz betonowe mostki przydrożne, omurowania torów kolejowych.

4 stan. Niedźwiedź 475; Węglarka 380; Rola 480; g. Zamczysko 465.

Collema auriforme (With.) Coppins \& Laundon [=C. auriculatum Hoffm.] - Omszałe skały wapnistych piaskowców; miejsca dość cieniste.

1 stan. Pot. Adamczyków 400.

C. dichotomum (With.) Coppins \& Laundon $[=C$. fluviatile (Huds.) Steud, Leptogium cataclystum (Koerb.) Harm.] - Stale ociekające czystą wodą progi i wodospady skalne $\mathrm{z}$ bezwapiennych piaskowców; miejsca cieniste i bardzo strome. 1 stan. pot. Rybny Potok 720 .

C. flaccidum (Ach.) Ach. - Wilgotne piaskowce bezwapienne (głazy wystające $\mathrm{z}$ wody potoków); miejsca dosyć cieniste.

5 stan. pot. Adamczyków 400, 760; pot. Bajtków Potok 435; Udziele 480; S stok g. Zamczysko 464. 
C. fuscovirens (With.) Laundon [= C. tuniforme (Ach.) Ach.] - Silnie wapniste piaskowce; miejsca suche i widne.

7 stan. m. Ciżami a Podgródkiem 410; Gronoszowa 410; Niedźwiedź 475; podnóże g. Turnia 560; Kozłówka 450; Sadowa 285; g. Zamczysko 540.

C. polycarpon Hoffm. - Silnie wapniste skały; osuwiska nad rzekami; miejsca suche i silnie nasłonecznione.

1 stan. Sadowa 285.

C. tenax (Sw.) Ach. em. Degel. - Gliniasto-wapnista gleba w miejscach okresowo dość wilgotnych.

3 stan. pot. Suchy 390; pot. Brzeźna 435; g. Zamczysko 540 .

Cybebe gracilenta (Ach.) Tibell [= Coniocybe gracilenta Ach.] - Rozkładające się drewno (jamka w butwiejącym pniaku).

1 stan. g. Mogielica 1145.

Cystocoleus ebeneus (Dillw.) Thwaites [ = Coenogonium nigrum auct.] - Bezwapienne piaskowce (zacienione, pionowe skałki).

2 stan. g. Śnieżnica 970; g. Bystra Góra 660.

Dermatocarpon miniatum (L.) Mann - Pionowe, silnie wapniste piaskowce (skały w głębokim wąwozie).

1 stan. S stok g. Zamczysko 465 .

Dibaeis baeomyces (L. fil.) Rambold \& Hertel [= Baeomyces roseus Pers.] - Gliniasta gleba, obok ścieżek, na nieużytkach i na skarpach; miejsca widne i suche.

76 stan. g. Luboń Mały 710, 870; g. Cymbałowa 540; Krzysie 875; pot. Kozi 540; Pod Szczebel 765; g. Mała Góra 695; Łabuzy 500; Zarębie 495; m. pot. Szarków a g. Okrągła 455; pot. Bajtków Potok 435; m. g. Adamczykowa a Piwowarami 560; g. Gródek 490; Przylasek 500; Filipiaki 585; g. Lubogoszcz 670; Krzynów 615; Dymasy 510; Las Puciaki 500; Pod Gronią 615; g. Ćwilin 655, 670, 1050; Sępki 520; pot. Wierzbanica 575; g. Śnieżnica 930; Do Uboczy 750; Wróble 665; m. Łąkami a g. Cyrki 740, 830; pol. Folwarczna 940; pot. Rosochaniec 575; g. Jasień 920; m. g. Myszyca a Przysłopkiem 815; g. Myszyca 865; podnóże g. Łopień 560; pol. Przysłopek 910; g. Łopień 780; pot. Rybny Potok 510; g. Mogielica 820, 850; m. g. Wiśnia a g. Rydznik 880; Czarna Rzeka 600; g. Hala 820; g. Turnia 520; pol. Brogi 595; Nowy Dwór 455; Bukowina 790; m. Burdy a g. Byniowa 620; g. Jasieńczyk 850; Załpeński Potok 400; dol. Wilczy Rynek 405; Ogrelówka 450; Golców 570; Cecygówka 735; Tokarze 680; Rozpite 475; Sarczyn 555; Jastrzębie 555; dol. Rozdziele 340; Jaworzna 640; Szałas 845; g. Pępówka 570; Lasek 595; g. Jaworze 855; Dobrocierz 500; Zagórze 540; g. Komera 555; g. Chełm 745, 765; pot. Brzeźna 455; pot. Suchy 380; Kobyłczyna Niżna 335; Wierzchowina 460; Klenie 625; m. Litaczem a g. Łysa Góra 570.

Diploschistes gypsaceus (Ach.) A. Zahlbr. [ $=$ D. cretaceus (Ach.) Lett.] - Wapniste piaskowce (skałki nieco zacienione).

1 stan. g. Zamczysko 480.

D. muscorum (Scop.) R. Sant. [= D. bryophilus (Ach.) A. Zahlbr.] - Obumierające mchy naziemne i naskalne; zwykle miejsca dość widne.

8 stan. Dawce 580; g. Turnia 565; m. Bulandami a Chlipałami 500; Kurzejówka 315; g. Bystra Góra 650; Kobyłczyna 630; pot. Suchy 420; S stok g. Zamczysko 465.

D. scruposus (Schreb.) Norm. [ $=$ D. violarius $(\mathrm{Nyl}$,$) A. Zahlbr.] - Bezwapienne$ piaskowce skałki. głazy, stosy kamieni, gołoborza; miejsca suche i widne.

20 stan. g. Bydłoniowa 430; pot. Bajtków Potok 445; g. Kotelnica 745; Dawce 580; g. Śnieżnica 970; g. Kobylica 880; Smolenie 630; Fudaleje 570; pol. Jaworze 945; Czarna Rzeka 630; g. Turnia 520; pot. Szczawa 560; Kozłówka 450; g. Szkiełek 720; pot. Suchy 420; Na Padole 700; Na Kolonii 740; Podlesie 555; g. Zamczysko 480, 540. 
Diplotomma epipolium (Ach.) Arnold - Silnie wapniste skały piaskowcowe; miejsca suche i nasłonecznione.

3 stan. Kozłówka 450; g. Zamczysko 510, 540.

D. nivalis (Bagl. \& Carestia) Hafellner [ $=$ D. margaritacea '(Sommerf.)' Szatala] - Lekko wapniste piaskowce (skałki, głazy); miejsca suche i widne.

4 stan. Czarna Rzeka 630; Sadowa 285; g. Zamczysko 480, 540.

Dirina stenhammari (Fr. ex Stenh.) Poelt \& Follman $[=$ Lecanactis stenhammari (Fr. ex Stenh.) Arnold] - Wapniste piaskowce (ocienione, pionowe skałki). 1 stan. g. Bystra Góra 660 .

Endocarpon pusillum Hedw. - Zwietrzelina na silnie wapnistych skałach piaskowcowych; miejsca suche i widne.

1 stan. Niedźwiedź 475.

Enterographa zonata (Koerb.) Källsten in Torrente \& Egea [ = Opegrapha zonata Koerb.] - Bezwapienne, pionowe, zwykle lekko zacienione skałki piaskowcowe. 4 stan. g. Śnieżnica 970; pol. Piekło 620; g. Mogielica 1060; g. Bystra Góra 660.

Epilichen scabrosus (Ach.) Clem. [ = Buellia scabrosa (Ach.) Massal. $]$ - Na plesze Baeomyces rufus; miejsca suche i widne.

1 stan. Bruski 630.

Evernia prunastri (L.) Ach. - Kora drzew liściastych przydrożnych lub samotnie rosnących.

19 stan. Biedaki 470; Dudziki 500; Płoszczyce 600; Białe 610; pot. Rybny Potok 450; Zaświerszcze 635; g. Mogielica 900; g. Hala 905; Kuźle 505; g. Modyń 1025; Moczarki 405; Brzeg 570; g. Sikorzec 800; Potoki 550; Na Padole 600; Łąki 570; m. Cabałówką a Przyszową 445; g. Soślina 440; Sadowa 425.

Flavoparmelia caperata $($ L.) Hale [= Parmelia caperata $($ L.) Ach. $]$ - Kora starych drzew liściastych.

27 stan. Siepańcowa 460; Wilczakowa 310; Karpieńcowa 545; Podobin 580; Dudziki 500; Kuczaje 545; Rubisie 525; Janie 550; Zaświercze 635; Zagórze 600; g. Hala 905; Kuźle 505; Sadowa 415; Moczarki 385; Brzeg 570; dol. Rozdziele 335; Na Korabiu 705; Jaworzna 425; dol. Kamionki Małej 360; Przyszowa 440; Na Kolonii 680; dol. Żmiącej 385, 430; dol. Krosnej 335; g. Soślina 440; Kobyłczyna Niżna 350; pot. Brzeźna 430.

Graphis scripta (L.) Ach. - Kora starych drzew liściastych, niekiedy jodeł. 30 stan. Las Luboński 605; g. Luboń Wielki 985; m. g. Mała Góra a g. Szczebel 885; g. Lubogoszcz 870, 940; Budacze 790; g. Śnieżnica 960; Łąki 840; g. Jasień 945; Polana Skalne 1000; Bruski 720; Białe 610; g. Krzysztonów 985, 1005; g. Łopień 885; g. Mogielica 900, 1030, 1150; pot. Mogielica 725, 765, 1040; pot. Rybny Potok 775; Stara Karczma 450; g. Modyń 915; dol. Wilczy Rynek 570; dol. Jabłoniec 385; dol. Krosnej 335; Kobyłczyna Niżna 310; g. Chełm 765; poniżej g. Zamczysko 300.

Gyalecta jenensis (Batsch) A. Zahlbr. - Skały piaskowcowe o dużej zawartości węglanu wapnia, np. nad brzegami potoków.

1 stan. pot. Bajtków Potok 435 .

Hypocenomyce scalaris (Ach.) Choisy [= Lecidea scalaris (Ach.) Ach.] - Kora drzew iglastych głównie u nasady pni, rzadziej murszejące drewno.

50 stan. g. Luboń Mały 710, 875; Krzysie 700; Michalaki 635; pot. Adamczyków 580; Zarębie 480; m. pot. Szarków a g. Okrągła 455; Kozówka 615; pol. Imka 510; pot. Szarków 390; Na Snoze 465; m. g. Adamczykowa a Piwowarami 560; g. Groń Herby 730; Filipiaki 670; pot. Antosów 540; Dymasy 510; g. Czarny Dział 640; Piechówka 570; Kaima 560; podnóże g. Łopień 560; Węglarnia 530; g. Kostrza 685; m. g. Świnia Góra a Wieszkami 560; g. Styr 660; g. Zęzów 690; Stara Karczma 615; Nagórze 640; dol. Wilczy Rynek 405; dol. Jabłoniec 445; Granica 580; Podokowaniec 720; pot. Załpeński Potok 400; g. Kuklacz 625; g. Szklarka 600; g. Łyżka 685; Rozpite 485; Dębina 580; Na Padole 515; g. Kobyła 600; g. Kamera 
690; Drużków Pusty 450; Klenie 560; g. Litacz 650; g. Gwizdor 590; g. Soślina 560; Podlesie 485; Wierzchowina 460; g. Łysa Góra 535; Sadowa 425; g. Szcząb 485.

Hypogymnia farinacea Zopf [ $=H$. bitteriana (A. Zahlbr.) Räs.] - Kora drzew iglastych rosnących w naturalnych lasach.

1 stan. S grzbiet g. Jasień 945.

H. physodes (L.) Nyl. - Kora drzew iglastych i liściastych, również martwe drewno.

170 stan. g. Luboń Mały 710, 870; Krzysie 700; pot. Kozi 560; Kubińcowa 395; Las Luboński 850; Pokrzywnik 875; g. Mały Groń 590, 720; g. Luboń Wielki 985; pot. Miedziany 900; Michalaki 635; g. Kiczora 720; pot. Adamczyków 580; pot. Kozieniec 520; Liszki 585; Dobrzany 665; Zarębie 480; Kozówka 615; g. Bydłoniowa 640; poniżej lasu Mocarze 640; pol. Imka 510, 535; pot. Szarków 385, 390; m. g. Adamczykowa a Piwowarami 560; Potoczki 560; g. Kotelnica 665; pot. Antosów 540; g. Lubogoszcz 670, 820, 855, 900; g. Groń Herby 730; g. Wierzbowska Góra 720; Ciastonie 700; Dymasy 510; g. Czarny Dział 640; g. Dzielec 590; Dudziki 490, g. Ostra 780; Wróble 580, 665; g. Cyrki 640; g. Śnieżnica 900, 1000; Płoszczyce 605; m. Łąkami a g. Cyrki 840; pot. Rosochaniec 615; Piechówka 570; g. Ćwilin 655, 1025, 1030; Kaima 555; Bruski 625; pol. Pieżgula 1000; Polana Skalne 1000; g. Jasień 945, 1030; Przysłopek 855; Na Foksowym 810; Białe 610; Rola 510; g. Krzysztonów 985; pol. Jaworze 945; g. Łopień 770; pol. Wyśnikówka 1100; g. Mogielica 835, 900, 1000, 1165; Zalesie 550; pot. Rybny Potok 450, 510; Zaświercze 635; pot. Mogielica 725; g. Styr 660; g. Hajdowska Góra 800; g. Hala 870; pol. Brogi 840; Bednarki 470; Podlesie 420; Zęzów 685; Bukowina 790; pot. Szczawa 560; m. Zbludzkimi Wierchami a Bystrą Górą 730; m. Wierchami a Ślagami 760; Ślagi 760; g. Tokoń 845, 925; Stara Karczma 595; Paryż 575; g. Modyń 835, 915, 955, 1025; m. Burdami a Byniową 600; Moczarki 385; g. Ostra 865, 925; dol. Wilczy Rynek 405, 480; Nagórze 640; Moczarki 405; g. Jasieńczyk 810; g. Dzielec 615; dol. Jabłoniec 385, 445; Granica 580; Zarębki 550; Brzeg 570; Podokowaniec 660, 720; g. Szkiełek 675; g. Sikorzec 800; g. Stawiska 650; Załpa 330; Załpeński Potok 400; Kęcina 575; g. Kuklacz 625, 650; dol. Potoki 550; Łąki 570; Szklarka 600; Na Jaworzu 735; Kopciówka 650; Pod Rębiskiem 565; pot. Między Brzegi 520; g. Kuklacz 675; g.Łyżka 685, 765; Jaworzna 640; Rozpite 485; g. Pępkówka 615, 750; Głowaczyzna 575; dol. Jaworznej 385, 425; g. Sałasz 895; pot. Na Padole 515; Kobyła 600; g. Wielka Góra 775; Kopiec 570; g. Jaworze 870, 915; m. Cabałowką a Przyszową 445; dol. Krosnej 335, 430; Kobyłczyna 645; Zagórze 570; g. Kamera 650; Kobyłczyna Niżna 400; Na Górach 690; Podlesie 485; g. Babia Góra 680; pot. Suchy 445; g. Litacz 650; g. Gwizdor 590; pot. Brzeźna 435, 480; g. Soślina 565; Wierzchowina 460; Klenie 615; g. Chełm 750, 785; Sadowa 425; Zawadka 600; Łazy 540; poniżej g, Zamczysko 300; g. Szcząb 425, 485.

H. tubulosa (Schaer.) Hav. - Kora drzew iglastych i liściastych.

7 stan. Biedaki 470; g. Ćwilin 1030; m. Łąkami a g. Cyrki 840; g. Łopień 840; g. Kuklacz 650, 670; g. Soślina 440.

H. vittata (Ach.) Parrique - Kora starych drzew iglastych (świerki), rzadko liściastych (buki) w naturalnych lasach.

2 stan. poniżej Polany Skalne 1000; pol. Wyśnikówka 1100.

\section{Immersaria athroocarpa (Ach.) Rambold \& Pietschm in Rambold [= Lecidea} athroocarpa (Ach.) Ach.] - Bezwapienne piaskowce (skałki, głazy, stosy kamieni); miejsca suche i nasłonecznione.

17 stan. g. Mała Góra 695; poniżej g. Bydłoniowa 430; g. Czarny Dział 640; g. Ogorzała 775; H. Ćwilin 1060; g. Śnieżnica 775; pot. Rosochaniec 575; pol. Łuki 1000; Polana Skalne 1050; H. Mogielica 1100; g. Hajdowska Góra 800; podnóże g. Turnia 520, 565; Jeżowa Woda 865; Na Korabiu 705; g. Szkiełek 740, 750.

Imshaugia aleurites (Ach.) S. L. F. Meyer [= Parmeliopsis aleurites (Ach.) Nyl.] - Kora drzew iglastych.

8 stan. poniżej przys. Krzysie 700; pol. Rogowcówka 890; Kozówka 615; Groń Herby 730; g. Czarny Dział 640; Piechówka 570; g. Mogielica 1160; m. g. Litacz a Łysą Górą 570. 
Lecanactis dilleniana (Ach.) Koerb. - Bezwapienne piaskowce (pionowe lub podwieszone, zacienione skały).

1 stan. g. Śnieżnica 970.

L. latebrarum (Ach.) Arnold [ = Lepraria latebrarum (Ach.) Ach.] - Bezwapienne piaskowce (zacienione, pionowe skałki).

2 stan. g. Śnieżnica 970; pot. Rosochaniec 575.

Lecania inundata (Koerb.) M. Mayrhofer in Nimis \& Poelt - Silnie wapniste piaskowce (skałki); miejsca suche i widne.

1 stan. g. Zamczysko 540 .

Lecanora albella (Pers.) Ach. $[=$ L. pallida (Schreb.) Rabenh.] - Kora starych buków w naturalnych lasach.

2 stan. Polana Skalna 1000; g. Hala 905.

L. albescens (Hoffm.) Branth \& Rostr. - Betonowe mostki, głazy piaskowcowe, niekiedy stare deski.

5 stan. Fudaleje 575; Sorysz 740; Przyszowa 435; Pisarzowa 445; Męcina 380.

L. argentata (Ach.) Malme $[=L$. subfuscata $\mathrm{H}$. Magn.] - Kora drzew liściastych oraz iglastych (jodły).

19 stan. Luboński Potok 495; g. Luboń Wielki 985; las Mocarze 500; g. Wierzchowska Góra 720; g. Ćwilin 715; g. Łopień 615, 705, 895; g. Mogielica 1040; pot. Mogielica 900, 1000; Zarąbki 550; Potoki 550; Tokarze 680; poniżej przys. Kunówka 590; Głowaczyzna 575; g. Jaworze 915; Wierzchowina 460; podnóże g. Zamczysko 300.

L. campestris (Schaer.) Hue - Bezwapienne piaskowce (skałki, głazy); miejsca suche $\mathrm{i}$ widne.

2 stan. Kubińcowa 420; g. Bystra Góra 660.

L. carpinea (L.) Vain. - Kora drzew liściastych, zwykle na drzewach wolno rosnących.

52 stan. Moskałowa 420; Kubińcowa 395; Luboński Potok 495; Wilczakowa 510; g. Luboń Wielki 985; pot. Kozieniec 520; pot. Szarków 400; Podobin 560; Dudziki 490; Muszyny 545; Kaima 555, 560; Zawady 520; Bruski 625; Węglarnia 475; Zagórze 600; g. Kostrza 710; g. Mogielica 900; Podlesie 420; pot. Szczawa 560; m. Bulandami a Chlipałami 500; Stara Karczma 450, g. Modyń 915, 1025; m. Burdami a g. Byniowa 600; Moczarki 405; Stara Wieś 460; dol. Jabłoniec 385; Kurczaby 500; Zarębki 550; Tokarze 680; dol. Roztoka 610; Potoki 550; Łąki 570; Rozpicki Potok 340; pot. Między Brzegi 520; Szarówka 680; Rozdziele 325; Głowaczyzna 575; Jaworzna 340; Łukowica 445, 510; dol. Żmiącej 340; g. Jaworze 915; dol. Krosnej 335, 350; Kobyłczyna Niżna 310, 400; g. Babia Góra 680; pot. Suchy 445; pot. Brzeźna 430; Sadowa 425.

L. cenisia Ach. - Bezwapienne piaskowce (skałki, luźne murki, stosy kamieni, gołoborza); miejsca suche i widne.

14 stan. poniżej g. Bydłoniowa 430; g. Ogorzała 775; Przysłopek 870; g. Mogielica 1165; g. Turnia 520, 565; H. Modyń 1015; g. Szkiełek 720, 750; Jaworzna 660; Strzeszyce 305; Na Padole 700; g. Babia Góra 720; g. Chełm 750.

L. chlarotera Nyl. - Kora drzew liściastych zwykle rosnące wzdłuż dróg lub samotnie.

48 stan. Rola 480; Zawady 520; Folwark 500; Płoszczyce 604; Pietoniówka 450; Bruski 625; pot. Szarków 400; Biedaki 470; Bednarki 470; Rupniów 400; Dwór nad Łososiną 385; Kobyłczyna Niżna 400; Pod Rębiskiem 580; pot. Między Brzegi 520; Mordarka 450; Potok 400; Załpa 330; Kęcina 575; Kurczaby 500; Moczarki 405; Jastrzębie 500; Świdnik 390; dol. Roztoka 610; Łukowica 445, 510; pot. Zawada 540; Stara Wieś 460; pot. Brzeźna 430; Soślina 470; Stara Karczma 450; Zbludza 490; Paryż 575; Wójciczki 435; Sadowa 425; dol. Rozdziele 325; dol. Krosnej 350; pot. Szczawa 560; Bulandy 500; Szynaliki 404; Potoki 
560; g. Jasień 1050; pot. Kozieniec 520; Węglarnia 475; Na Korabie 705; Dudziki 500; Siepańcowa 460; Muszyny 545; Kubińcowa 395.

L. conizaeoides Nyl. ex Cromb. [ = L. pityrea Erichs., L. conizaea auct.] - Kora drzew iglastych oraz liściastych.

12 stan. g. Luboń Wielki 985; powyżej przys. Kozówka 615; g. Kotelnica 665; g. Dzielec 590; g. Kostrza 685, 710; g. Dzielec k. Lososiny 615; g. Szkiełek 675, 740; Kopciówka 650; g. Kobyła 600; Kobyłczyna 645.

L. crenulata Hook. - Silnie wapniste skały piaskowcowe.

2 stan. poniżej g. Bydłoniowa 430; g. Zamczysko 540.

L. dispersa (Pers.) Sommerf. - Piaskowce (skałki, głazy) oraz betonowe obeliski, mostki, omurowania torów kolejowych, mury cmentarne; miesca suche i widne. 21 stan. Zarębie 370; pot. Szarków 390; m. Ciżami a Podgródkiem 410; Bołdony 565; Gronoszowa 410; Niedźwiedź 475; las Puciaki 500; Rola 480; Tokarzówka 695; Węglarka 380; Piekiełko 375; Kozłówka 450; g. Golców 745; Potoki 550; dol. Rozdziele 360; pot. Zawada 470; Na Padole 700; Pisarzowa 445, 475; pot. Suchy 420; Sadowa 285.

L. expallens Ach. - Kora drzew liściastych rosnących samotnie lub koło dróg; tylko w stanie płonnym.

23 stan. pot. Szarków 400; Myszoglądy 455; Kopytki 500; Zawady 520; Węglarnia 475; Zalesie 550; Pietoniówka 445; Bednarki 470; Podlesie 420; pot. Szczawa 560; Rupniów 400; g. Tokoń 845; Byniowa 650; Limanowa 425; Podokowaniec 660; Kunówka 590; Szarówka 670; dol. Żmiącej 430; g. Chełm 765; Kobyłczyna Niżna 350; g. Łysa Góra 535; Sadowa 425; g. Szcząb 435.

L. hageni (Ach.) Ach. - Na korze wierzb rosnących w miejscach zapylonych. 1 stan. Szynaliki 405.

L. intricata (Ach.) Ach. - Bezwapienne piaskowce (luźne murki, stosy kamieni, gołoborza); miejsca suche i widne.

44 stan. g. Cymbałowa 570; Karpierzowa 720; g. Mała Góra 695; Michalaki 635; g. Bydłoniowa 640; pot. Szarków 390; Sowy 640; g. Lubogoszcz 925, 950; Filipiaki 630; m. Groń Herby a Wierzbowską Górą 700; g. Witów 710; g. Wierzbanowska 715; g. Ogorzała 800; H. Ćwilin 1010, 1060; g. Śnieżnica 775; pot. Rosochaniec 625; pol. Łuki 1015; Przysłopek 870; Bruski 600; Polana Skalne 1050; H. Mogielica 1060; pol. Jaworze 945; pol. Wyśnikówka 1100; g. Mogielica 1165; polanki poniżej g. Cyrla 690; g. Hajdowska Góra 800; g. Turnia 520, 565; H. Modyń 1015; g. Ostra 870; Pod Modyniem 880; g. Jasieńczyk 810; g. Golców 730; Jeżowa Woda 865; Na Korabiu 705; Szałas 875; g. Pępkówka 750; pol. Sałasz 875; Na Kolonii 740, 790; g. Chełm 750.

L. intumescens (Rebent.) Rabenh. - Kora starych buków w naturalnych lasach. 5 stan. g. Śnieżnica 970; g. Mogielica 900, 1040; g. Modyń 915, 955.

L. muralis (Schreb.) Rabenh. - Wapniste i bezwapienne piaskowce (skałki, głazy, stosy kamieni, luźne murki. gołoborza), cegły, mury cmentarne, podłoże betonowe, a nawet nasadowe części pni starych sosen.

76 stan. pot. Śmigawka 510; Krzysie 875; Karpierzowa 720; pot. Miedziany 700; g. Kamionka 585; Potok 420; Kuce 390; pot. Szarków 390; poniżej g. Bydłoniowa 430; pot. Bajtków Potok 435; g. Kotelnica 745; g. Gródek 490; Sowy 630; g. Lubogoszcz 965; Krzynów 615; Spyrkowa 715; g. Witów 710; Las Puciaki 500; Farganusy 465; Dawce 580; g. Ogorzała 800; Kopytki 505; Muszyny 545; pot. Do Uboczy 715; g. Ćwilin 1050; H. Ćwilin 1010; g. Śnieżnica 775; g. Kobylica 880; pot. Rosochaniec 575; Fudaleje 575; g. Hajdowska Góra 800; Czarna Rzeka 630; g. Mogielica 1165; Kuźle 505; g. Hala 910; m. Bulandami a Chlipałami 500; Piekiełko 375; g. Pasierbiecka Góra 730, 765; Wierzch Góry 700; Młynne 740; Pod Modyniem 880; g. Byniowa 665; g. Jasieńczyk 810; Limanowa 405; g. Golców 745; g. Szkiełek 700, 720, 740; Załpa Górna 560; Sarczyn 555; Ogrojec 615; Jaworzna 660; g. Pępkówka 670, 750; pot. Zawada 470; Strzeszyce 305; dol. Jaworznej 350, 400; Na Padole 700; dol. Kamionki Małej 400; Jaworzna 675; g. Jaworze 885; Granica 715; Podlesie 555; Pagórek 275; g. Chełm 765, 770; pot. Suchy 420; g. Babia Góra 720; Męcina 380; Sadowa 285; Klenie 625, 660; pot. Brzeźna 435; g. Zamczysko 540. 


\section{L. piniperda Koerb. - Kora starych sosen w naturalnych drzewostanach.}

\section{1 stan. Piechówka 570.}

L. polytropa (Ehrh. ex Hoffm.) Rabenh. - Bezwapienne piaskowce (stosy kamieni, luźne murki, gołoborza); miejsca suche i widne.

85 stan. g. Cymbałowa 570; Filipcowa 580; g. Mały Groń 575; Karpierzowa 720; Kiece 550; Dobrzany 645; g. Bydłoniowa 640; las Mocarze 500; Groty 500; g. Kotelnica 720, 740; Sowy 605; g. Lubogoszcz 925, 965; Filipiaki 630; g. Kocia Górka 610; Krzynów 615; m. Groń Herbami a Wierzbowską Górą 700; g. Witów 710; g. Wierzbanowska 715; Sutory 470; Dzielec 590; g. Ogorzała 775, 800; Budacze 790; pot. Do Uboczy 750; H. Ćwilin 1010, 1060; g. Śnieżnica 775; pot. Rosochaniec 625; Pod Górą 615; pol. Łuki 1000, 1015; Smolenie 650; Polana Skalne 1050; Przysłopek 855; pol. Kozice 860; g. Mogielica 1165; H. Mogielica 1060, 1100; pol. Jaworze 945; g. Cyrla 690; Tokarzówka 695; g. Styr 660; m. Zagórzem a g. Grojec 570; g. Hala 910; g. Turnia 520; Zęzów 685; g. Pasierbiecka Góra 730; H. Modyń 1015; g. Kamionna 780; Młynne 740; g. Ostra 865, 870; Pod Modyniem 825, 880; g. Golców 730; Jeżowa Woda 865; g. Widoma 570 ; g. Szkiełek 700, 740; g. Sikorzec 800; Kęcina 645; g. Szklarka 600; Rozpite 475; g. Kuklacz 645; g. Ogrojec 615; Rosochodka 580; Na Korabiu 705; Szałas 845; g. Pępówka 670, 725, 790; g. Sałasz 875; Jaworzna 640; pol. Żmiąca 865; Na Kolonii 740, 790; Dobrocierz 500; Kobyłczyna 630; Granica 715; g. Litacz 650; Klenie 625; g. Chełm 750; pot. Brzeźna 435.

L. pulicaris (Pers.) Ach. $[=$ L. chlarona (Ach.) Nyl. $]$ - Kora drzew liściastych i iglastych oraz martwe drewno.

52 stan. Las Luboński 605; g. Luboń Wielki 985; Kubińcowa 395; g. Mała Góra 740; Michalaki 635; pot. Kozieniec 520; g. Lubogoszcz 960; Wróble 665; g. Śnieżnica 900; pol. Folwarczna 860; Kaima 555; g. Jasień 945; Na Foksowym 810; Białe 610; Węglarnia 475; Zalesie 550; g. Mogielnica 900, 1030, 1150, 1165; g. Kostrza 710; g. Hajdowska Góra 800; g. Hala 820; Zęzów 695; Bukowina 790; pot. Szczawa 560; g. Tokoń 845; g. Pasierbiecka Góra 730; Okrąg 565; g. Modyń 915, 1025; Byniowa 650; g. Ostra 865; g. Jasieńczyk 810; dol. Jabłoniec 385; g. Szkiełek 675; Załpeński Potok 415; dol. Potoki 550; Łąki 570; Na Jaworzu 720; Kopciówka 650; Pod Rębiskiem 565; pot. Między Brzegi 520; g. Łyżka 765; g. Pępówka 750; g. Jaworze 865, 870; dol. Krosnej 335; Kobyłczyna 645; g. Soślina 565; g. Chełm 765; pot. Brzeźna 480; Łazy 540.

L. rupicola (L.) A. Zahlbr. subsp. subplanata (Nyl.) Leuckert \& Poelt - Bezwapienne piaskowce (stosy kamieni, luźne murki, głazy, skałki); miejsca suche i widne.

55 stan. pot. Śmigawka 510; g. Cymbałowa 570; Karpierzowa 720; g. Mała Góra 695; Michalaki 635; Dobrzany 645; poniżej g. Bydłoniowa 430; g. Gródek 500; Sowy 640; g. Lubogoszcz 925, 965; Filipiaki 630; g. Wierzbanowska 715; Dawce 580; g. Ogorzała 775; Muszyny 545; Budacze 790; Udziele 480; g. Kobylica 880; pot. Rosochaniec 575; Przysłopek 870; Bruski 600; pol. Kozice 860; g. Mogielica 1100; g. Cyrla 690; g. Styr 660; Czarna Rzeka 600; pot. Szczawa 560; m. Bulandami a Chlipałami 500; g. Bystra Góra 660; Kozłówka 450; Wierzch Góry 700; H. Modyń 1015; Pod Modyniem 880; g. Jasieńczyk 810, 860; Jeżowa Woda 865; g. Szkiełek 720, 740, 745, 750; Na Korabiu 705; g. Pępówka 750; Na Padole 700; Jaworze 640, 675; Na Kolonii 740; Kobyłczyna 630; Granica 715; Burdak 495; g. Chełm 745, 750, 765; g. Turnia 520,565 .

L. saligna (Schrad.) A. Zahlbr. [=L. sarcopis (Ach.) Ach. $]$ - Kora drzew liściastych (wierzby, lipy) oraz martwe drewno (pniaki, kołki).

8 stan. Liszki 585; g. Ćwilin 1050; Folwark 500; Bednarki 545; Podlesie 420; m. Przysłopem a Wierzyką 775; g. Ostra 915; Ślagi 760.

L. sarcopidoides (Massal.) A. L. Sm. - Kora drzew iglastych (sosny) oraz murszejące pniaki.

2 stan. pol. Imka 535; g. Modyń 1025.

L. soralifera (Suza) Rds. - Bezwapienne piaskowce (stosy kamieni, luźne murki, głazy); miejsca suche i widne. 
10 stan. g. Kocia Górka 575; Budacze 790; H. Ćwilin 1060; H. Mogielica 1100; g. Cyrla 690; H. Modyń 1015; g. Kamionna 780; Jeżowa Woda 865; Na Korabiu 705; Kobyłczyna 630.

L. subcarpinea Szat. [=L. nemoralis Makarevicz] - Kora starych buków w naturalnych lasach.

1 stan. g. Hala 905.

L. subrugosa Nyl. - Kora starych buków w naturalnych drzewostanach. 13 stan. g. Śnieżnica 960; Polana Skalne 1000; g. Łopień 900; g. Mogielica 1020, 1040, 1060, 1150; pot. Mogielica 1000; g. Hala 905; g. Modyń 915, 955, 1025; Jaworzna 425.

L. sulphurea (Hoffm.) Ach. [= Lecidea sulphurea (Hoffm.) Wahlenb.] - Bezwapienne piaskowce (skałki, stosy kamieni, luźne murki, gołoborza); miejsca suche i widne.

8 stan. poniżej g. Bydłoniowa 430; g. Turnia 520, 560; m. Bulandami a Chlipałami 500; Udziele 480; g. Szkiełek 740; Na Padole 700; Jaworzna 675.

L. symmicta (Ach.) Ach. [= Lecidea symmicta (Ach.) Ach., Lecanora symmictera $\mathrm{Nyl}$.$] - Na murszejącym pniaku iglastym.$

1 stan. g. Mogielica 1170.

L. umbrina (Ach.) Massal. - Bezwapienne piaskowce (stosy kamieni, głazy nad potokami); miejsca suche i widne.

13 stan. Kubińcowa 420; Zarębie 370; pot. Szarków 390; Bołdony 565; Na Witów 680; m. Wierchami a Ślagi 760; Piekiełko 375; Jeżowa Woda 865; m. g. Kuklacz a Zarębkami 575; Rozpite 475; Ogrojec 615; Jaworzna 400; pot. Suchy 390.

L. varia (Hoffm.) Ach. - Martwe drewno (belki, ogrodzenia, poręcze mostów, płoty, stodoły), rzadziej kora drzew liściastych (brzozy).

16 stan. Łopień 705; Michalaki 635; Zagórze 600; Klęczany 290; Dwór k. Węglówki 445; Laskowa 320; Kuźle 505; Lisia Góra 620; Zarębki 550; g. Chełm 765; Okrąg 565; Janie 580; Byniowa 650; Szklarka 500; Żmiąca 295; Piwowary 560.

Lecidea confluens (Weber) Ach. - Bezwapienne piaskowce (skały, głazy, stosy kamieni, luźne mutki); miejsca suche i widne.

6 stan. pol. Łuki 1000; g. Turnia 520; H. Modyń 1015; g. Ostra 865; g. Jaworze 810; g. Chełm 750.

L. fuscoatra (L.) Ach. [= L. grisella Flk.] - Bezwapienne piaskowce (stosy kamieni, luźne murki, głazy); miejsca widne i suche.

75 stan. pot. Śmigawka 510; g. Cymbałowa 570; Filipcowa 580; g. Mały Groń 575; Karpierzowa 720; g. Mała Góra 695; Dobrzany 645; Kozówka 580; g. Bydłoniowa 430, 640; g. Kotelnica 665; Sowy 630; g. Lubogoszcz 925, 965; Filipiaki 630; m. Groń Herbami a Wierzbowską Górą 700; Ciastonie 710; g. Witów 650; g. Ogorzała 800; Muszyny 545; Budacze 790; H. Ćwilin 1010; 1060; g. Śnieżnica 775; pot. Rosochaniec 575, 625; g. Kobylica 880; g. Ćwilin 640; pol. Łuki 1000; pol. Wyśnikówka 1100; H. Mogielica 1100; g. Cyrla 690; g. Groń 730; g. Styr 660; Czarna Rzeka 630; g. Turnia 520, 565; m. Bulandami a Chlipałami 500; g. Pasierbiecka Góra 730; H. Modyń 1015; g. Kamionna 780; g. Ostra 870; Pod Modyniem 880; g. Jasieńczyk 810, 860; g. Golców 730, 745; Jeżowa Woda 865; g. Szkiełek 740, 750; g. Stawiska 605; Kęcina 645; Sarczyn 555; Na Korabiu 705; Szałas 845; g. Pępkówka 670, 750, 770; Jaworzna 640, 675; pol. Żmiąca 865; dol. Kamionki Małej 360; Na Kolonii 740, 790; g. Jaworze 855; Zagórze 680; Kobyłczyna 630, 675; Granica 715; g. Babia Góra 720; g. Chełm 745, 770; Klenie 625, 660; pot. Brzeźna 435 .

L. lactea Flk. ex Schaer. [= L. pantherina (Ach.) Th. Fr.] - Bezwapienne piaskowce (naturalne skałki, luźne murki, stosy kamieni, gołoborza); miejsca suche i widne.

38 stan. Karpierzowa 720; g. Mała Góra 695; Dobrzany 645; poniżej g. Bydłoniowa 430; g. Lubogoszcz 950; m. Groń Herbami a Wierzchowską Górą 700; g. Wierzbanowska 715; g. Czarny Dział 640; g. Ogorzała 775; H. Ćwilin 1010, 1050; pot. Rosochaniec 575; g. Kobylica 880; pol. Łuki 1000; Przysłopek 
870; Bruski 625; Polana Skalne 1050; pol. Kozice 860; H. Mogielica 1100; H. Styr 660; g. Turnia 565; pot. Szczawa 560; m. Bulandami a Chlipałami 500; H. Modyń 1015; g. Kamionna 780; g. Ostra 870; Pod Modyniem 880; g. Jasieńczyk 810, 830; Jeżowa Woda 865; g. Szkiełek 720, 745; Na Korabiu 705; g. Pępówka 750; Burdak 495; g. Chełm 750, 770; Klenie 660.

L. lithophila (Ach.) Ach. - Bezwapienne piaskowce (stosy kamieni, luźne murki, głazy); miejsca zwykle suche i widne.

27 stan. g. Cymbałowa 570; Bydłoniowa 640; g. Lubogoszcz 925, 965; Filipiaki 630; g. Ogorzała 800; H. Ćwilin 1050; g. Śnieżnica 775; pot. Rosochaniec 625; Przysłopek 870; H. Mogielica 1100; g. Cyrla 690; g. Hala 910; H. Modyń 1015; g. Kamionna 780; Pod Modyniem 880; g. Ostra 865; Jeżowa Woda 865; g. Szkiełek 740, 745; Na Korabiu 705; Szałas 845; Jaworzna 675; pol. Żmiąca 865; Na Kolonii 790; Kobyłczyna 630; g. Chełm 750.

L. lurida (Ach.) DC. - Warstewka humusu pokrywająca skały piaskowcowe; miejsca nasłonecznione.

1 stan. m. Ciżami a Podgródkiem 410.

L. plana (Lahm. in Koerb.) Nyl. - Bezwapienne piaskowce (stosy kamieni, luźne murki); miejsca suche i widne albo nieco zacienione.

28 stan. Karpierzowa 720; g. Lubomierz 925; m. Groń Herbami a Wierzbowską Górą 700; Ciastonie 720; g. Witów 650; g. Czarny Dział 640; g. Ogorzała 775; Drągówka 670; Budacze 790; H. Ćwilin 1010, 1060; pot. Rosochaniec 625; pol. Budaczowa 850; pol. Łąki 1000; pol. Kozice 860; pol. Jaworze 945; g. Lopień 780; H. Mogielica 1060, 1100; poniżej g. Cyrla 690; g. Hale 910; H. Modyń 1015; Jeżowa Woda 865; Sarczyn 555; g. Kuklacz 645; Na Kolonii 790; g. Chełm 750; Klenie 660.

L. pullata (Norm.) Th. Fr. - Kora drzew iglastych (jodły) w naturalnych lasach; zwykle w stanie płonnym.

6 stan. Kubińcowa 395; g. Lubogoszcz 900; g. Jasień 1050; g. Modyń 1025; g. Ostra 865; pot. Brzeźna 480.

L. turgidula Fr. - Nagie, stare murszejące pniaki w naturalnych drzewostanach. 1 stan. g. Mogielica 1160.

Lecidella asema (Nyl.) Knoph \& Hertel [ = Lecidea subincongrua Nyl.] - Bezwapienne piaskowce (stosy kamieni, luźne murki); miejsca suche i widne.

12 stan. g. Mała Góra 695; g. Ćwilin 1060; m. Zagórzem a g. Grojec 570; Zęzów 685; Wierzch Góry 700; g. Ostra 870; Pod Modyniem 880; g. Jasieńczyk 810; Jeżowa Woda 865; Kęcina 645; Kaleń 680; g. Chełm 770 .

L. carpathica Koerb. [= Lecidea carpathica (Koerb.) Szatala] - Bezwapienne lub słabo wapniste piaskowce (skałki, płyty kamienne, stosy kamieni, luźne murki, gołoborza, głazy nad potokami); miejsca suche i widne.

37 stan. pot. Śmigawka 510; pot. Szarków 390; g. Bydłoniowa 430; g. Gródek 490; g. Wierzbanowska 715; las Puciaki 500; Kopytki 505; Muszyny 545; Budacze 790; H. Ćwilin 1010; g. Kobylica 880; pot. Rosochaniec 575; pol. Łąki 1015; Fudaleje 575; pol. Przysłopek 910; g. Mogielica 1165; Czarna Rzeka 600; Kuźle 505; g. Hala 910; g. Turnia 565; Kozłówka 450; H. Modyń 1015; Pod Modyniem 880; g. Jasieńczyk 810; g. Szkiełek 740, 750; Jaworzna 660; g. Pępkówka 670; Na Padole 450; g. Szałas 875; g. Jaworze 855; Granica 715; Podlesie 555; g. Chełm 745, 765, 770; Sadowa 285.

L. elaeochroma (Ach.) Choisy [= Lecidea olivacea (Hoffm.) Massal.] - Kora drzew liściastych zwykle rosnących blisko skraju lasu lub koło dróg.

61 stan. Siepańcowa 460; Kubińcowa 395; Las Luboński 605; Luboński Potok 495; Wilczakowa 510; Szarków 470; g. Luboń Wielki 985; Michalaki 635; pot. Bajtków Potok 435; Myszoglądy 455; Dudziki 490; Kopytki 500; Kuczaje 545; Muszyny 545; g. Śnieżnica 960; Szczypty 650; Folwark 500; Bruski 625, 720; pol. Jaworze 945; g. Łopień 820, 900; g. Mogielica 900, 1030, 1060; pot. Mogielica 765; Węglarnia 475; Pietoniówka 445; g. Hala 905; pot. Szczawa 560; Rupniów 400; Dwór 385; Wójciczki 435; Stara Karczma 450; g. Modyń 915; m. Burdami a Byniową 650; Stara Wieś 460; Jabłoniec 385; Kurczaby 500; Załpa 320; Łąki 570; Rozpicki Potok 340; Kunówka 590; Pod Rębiskiem 580; Jastrzębie 550; Jaworze 425; Zawada 540; Łukowica 445; Na Padole 515; dol. Żmiącej 340, 430; g. Jaworze 915; dol. Krosnej 335, 
350; Wierzchowina 460; Brzeźna 430, 465; Sadowa 425; Tłoki 270; Poddąbrowie 520; poniżej g. Zamczysko 325 .

L. stigmatea (Ach.) Hertel \& Leuckert [= Lecidea stigmatea Ach., L. micacea Koerb., L. vulgata A. Zahlbr.] - Wapniste lub bezwapienne piaskowce (skałki, kamienie wśród traw, stosy kamieni), niekiedy również podłoże betonowe.

19 stan. g. Śnieżnica 1005; Smolenie 650; Rubisie 625; pot. Rosochaniec 580; g. Bystra Góra 660; Kozłówka 450; Załpeński Potok 415; Rozpite 475; pot. Zawada 470; Strzeszyce 305; dol. Jaworznej 400; Pisarzowa 475; dol. Kamionki Małej 360; g. Jaworze 855; g. Chełm 765; g. Babia Góra 720; Sadowa 285; Zawadka 605 ; g. Zamczysko 540 .

L. viridans (Flot.) Koerb. [= Lecidea viridans (Flot.) Lamy] - Skały piaskowcowe; suche i widne miejsca.

1 stan. Kozłówka 450.

Lempholemma polyanthes (Bernh. in Schad.) Malme [ = L. myriococcum (Ach.) Th. Fr.] - Naga gleba wśród skał piaskowcowych.

1 stan. m. Ciżami a Podgródkiem 410.

Lepraria flavescens Clauz \& Roux [= L. crassissima auct.] - Lekko wapniste piaskowce (skały); miejsca pionowe i nieco cieniste.

3 stan. Śnieżnica 970; g. Bystra Góra 660; Kozłówka 450.

L. incana (L.) Ach. [ $=$ L. aeruginosa auct., L. glaucella (Flk.) Nyl.] - Omszała kora drzew liściastych i iglastych, omszałe skały piaskowcowe, butwiejące pniaki, czasem gleba; przeważnie miejsca cieniste.

86 stan. Moskałowa 420; Luboński Potok 585; g. Mała Góra 885; g. Mały Groń 720; Śmietanowa 460; g. Luboń Wielki 985; Kozówka 615; poniżej lasu Mocarze 500; pot. Szarków 390; g. Kotelnica 665; g. Lubogoszcz 870, 920, 925, 950; Szynaliki 405; Antosów 670; g. Wierzbowska Góra 720; g. Groń Herby 730; Janie 440; Dawce 480; g. Dzielec 590; g. Ostra 780; pot. Wierzbanica 575; Budacze 790; Wróble 665; g. Śnieżnica 930, 960; g. Ćwilin 985, 1020; m. Łąkami a g. Cyrki 840; pot. Jamne 725; Szczypty 650; Kaima 560; Smolenie 650; Polana Skalne 1000; Janie 550; Bruski 720; g. Krzysztonów 1005; Białe 610; Rola 480; g. Łopień 770, 800, 840, 900; pol. Jaworze 945; g. Mogielica 1040, 1060, 1150; pot. Mogielica 1000; m. g. Świnia Góra a Wieszkami 560; pot. Rybny Potok 450, 510; Tokarzówka 655; Zagórze 600; g. Hala 905; Podlesie 420; g. Zęzów 690; Nowy Dwór 510; Rupniów 400; g. Modyń 915, 1025; pot. Byniowa 400; Moczarki 405; g. Dzielec 615; g. Okowaniec 790; Podokowaniec 720; Załpeński Potok 380; g. Kuklacz 660; Rozpicki Potok 340; Kopciówka 715; Sarczyn 555; Rozpite 485; Szałas 650; pot. Zawoda 510; Łukowica 455; dol. Kamionki Małej 360; dol. Żmiącej 335; dol. Krosnej 335; Zagórze 570; pot. Brzeźna 480; Kobyłczyna Niżna 310; Burdak 470; Klenie 660; Sadowa 425; poniżej g. Zamczysko 300; g. Szcząb 485 .

L. neglecta (Nyl.) Lettau [ = Crocynia neglecta (Nyl.) Hue] - Piaskowce; miejsca suche $\mathrm{i}$ widne.

8 stan. Krzysie 875; Filipiaki 630; H. Ćwilin 1010; g. Kobylica 880; g. Śnieżnica 775; g. Mogielica 1165; g. Turnia 520; g. Szkielek 740 .

Leproplaca xantholyta (Nyl.) Hue [ = Caloplaca xantholyta (Nyl.) Jatta] - Wapniste piaskowce (nasadowe części pionowych skał).

5 stan. g. Śnieżnica 970; pol. Piekło 620; g. Chełm 730; g. Zamczysko 480, 510.

Leptogium lichenoides (L.) A. Zahlbr. - Wapnista gleba na omszałych skałach piaskowcowych; miejsca lekko cieniste.

3 stan. Zarabie 400; m. Ciżami a Podgródkiem 410; poniżej g. Zamczysko 440.

Lobaria pulmonaria (L.) Hoffm. - Kora starych buków w naturalnych drzewostanach.

3 stan. g. Jasień 1050; g. Mogielica 1150; g. Modyń 1025. 
Lobothalia radiosa (Hoffm.) Hafellner [= Lecanora radiosa (Hoffm.) Schaer.] - Wapniste piaskowce (skałki, kamienie wśród traw).

6 stan. Potok 420; g. Bydłoniowa 430; pot. Bajtków Potok 435; Niedźwiedź 465; Kozłówka 450; Sadowa 285 .

Melanelia disjuncta (Erichs.) Hale [= Parmelia disjuncta Erichs.] - Bezwapienne piaskowce na gołoborzach.

1 stan. podnóże g. Turnia 565 .

M. elegantula (A. Zahlbr.) Essl. [= Parmelia elegantula (A. Zahlbr.) Szat.] - Kora drzew liściastych.

1 stan. Kurczaby 500.

M. exasperatula (Nyl.) Essl. [= Parmelia exasperatula $\mathrm{Nyl}$.] - Kora drzew liściastych rosnących samotnie oraz przy drogach.

30 stan. Kubińcowa 395; Kuczaje 545; Płoszczyce 605; Szczypty 650; Kaima 560; Folwark 500; Bruski 625; Dobra 470; m. Dobrą a g. Łopień 510; pot. Rybny Potok 450; Bednarki 470; m. Bulandami a Chlipałami 500; Paryż 570; Byniowa 650; Ogielówka 450; Zarąbki 550; g. Sikorzec 800; Kęcina 575; dol. Roztoka 610; Łąki 570; Kunówka 590; Growaczyzna 575; Litacz 610; Wola Brzezińska 530; g. Babia Góra 680; Kobyłczyna Niżna 350; Burdak 470; pot. Brzeźna 435; Zawadka 600; Łazy 540.

M. fuliginosa (Fr. ex Duby) Essl. in Egan [ = Parmelia fuliginosa (Fr. ex Duby) Nyl.] - Kora drzew liściastych (także graby), rzadko iglastych lub bezwapienne piaskowce.

68 stan. Siepańcowa 460; Kubińcowa 395; Karpieńcowa 545; g. Luboń Wielki 985; pot. Kozieniec 520; Potok 420; pot. Szarków 385, 400; g. Bydłoniowa 430; pot. Bajtków Potok 435; Kuce 410; g. Gródek 500; Dudziki 500; Kuczaje 545; g. Śnieżnica 960; g. Jasień 1050; Szczypty 650; Kaima 560; Zawady 520; Bruski 625, 720; Polana Skalne 1000; Dobra 470; Białe 610; g. Łopień 900; g. Mogielica 900, 1040, 1060, 1150; pot. Mogielica 765; pot. Rybny Potok 450; Zaświercze 635; Zagórze 600; g. Hala 870, 905; Bednarki 470; Podlesie 420; pot. Szczawa 560; Rupniów 400; Dwór 385; Stara Karczma 450; g. Modyń 915, 955, 1025; Moczarki 385; Limanowa 425; dol. Jabłoniec 385; Załpa 375; dol. Potoki 550; dol. Roztoka 610; Tokarze 680; Kopciówka 650; Pod Rębiskiem 580; dol. Rozdziele 325; Rozpite 495; Głowaczyzna 575; Jaworzna 425; Na Padole 600; dol. Żmiącej 430; m. Cabałowem a Przyszową 445; Krosna 300; Dobrocierz 480; pot. Brzeźna 480; g. Soślina 440; Kobyłczyna Niżna 310, 400; Wierzchowina 460; Sadowa 425.

M. subargentifera (Nyl.) Essl. [ = Parmelia subargentifera Nyl., P. verruculifera auct.] - Kora drzew liściastych, zwykle rosnących w pobliżu dróg.

15 stan. Krętoniowa 440; Janówka 460; Karpieńcowa 545; Potoczki 560; Szynaliki 405; Płoszczyce 600; Rola 480; Pietoniówka 445; m. Bulandami a Chlipałami 500; Załpa 375; Jastrzębie 500; Świdnik 390; Na Kolonii 680; g. Soślina 440; Brzeźna 465.

M. subaurifera (Nyl.) Essl. [= Parmelia subaurifera Nyl. $]$ - Kora drzew liściastych.

3 stan. Biedaki 470; pot. Mogielica 1040; g. Modyń 1025.

Menegazzia terebrata (Hoffm.) Massal. $[=M$. pertusa (Schrank.) Schaer. $]$ - Kora drzew liściastych rosnących w naturalnych lasach.

4 stan. Polana Skalna 1000; m. g. Kutrzycą a g. Krzysztonów 980; Białe 610; g. Mogielica 1150.

Micarea denigrata (Fr.) Hedl. [= Catillaria denigrata (Fr.) Hedl. $]$ - Nagie drewno (poręcze mostów, dachy szop, kołki, parkany, murszejące pniaki).

26 stan. Luboński Potok 520; g. Mała Góra 830; Liszki 585; Dobrzany 665; g. Bydłoniowa 640; pol. Imka 510; pot. Szarków 390; m. g. Adamczykowa a Piwowarami 560; Dymasy 510; m. Kaletami a Putami 495; pol. Łuki 1015; Dobra 470; g. Hala 830; Kuźle 505; g. Okrąg 565; m. Burdami a g. Byniowa 620; Pod Modyniem 825; Stara Wieś 460; g. Jasieńczyk 860; Na Jaworzu 720; Laskowa 320; g. Łyżka 680; Kobyłczyna Niżna 400; Brzeźna 455; pot. Brzeźna 480; Klęczany 290. 
M. lignaria (Ach.) Hedl. [ = Bacidia lignaria (Ach.) Lettau $]$ - Ocienione skały piaskowcowe.

1 stan. g. Śnieżnica 970.

M. peliocarpa (Anzi) Coppins \& R. Sant. [= Bacidia trisepta (Hellb.) A. Zahlbr.] - Bezwapienne piaskowce (głazy nad potokami, kamienie wśród traw).

3 stan. pot. Adamczyków 600; pot. Szarków 390; podnóże g. Łopien 560.

M. prasina $\mathrm{Fr}$. [ = Catillaria prasina $(\mathrm{Fr}.) \mathrm{Th} . \mathrm{Fr}$.$] - Butwiejące pniaki; miejsca$ cieniste i dosyć wilgotne.

9 stan. g. Lubogoszcz 670, 760, 920; g. Łopień 780, 880; Czarna Rzeka 700; Załpieński Potok 530; g. Kuklacz 660; g. Jaworzyna 820.

M. sylvicola (Flot.) Vězda \& Wirth [= Lecidea sylvicola Flot.] - Bezwapienne piaskowce (cieniste skały, kamienie).

3 stan. Luboński Potok 560; g. Śnieżnica 970; g. Ćwilin 1020.

Miriquidica leucophaea (Flk. ex Rabenh.) Hertel \& Rambold [= Lecidea leucophaea (Flk. ex Rabenh.) Nyl. - Bezwapienne piaskowce (stosy kamieni, gołoborza); miejsca suche $\mathrm{i}$ widne.

3 stan. g. Turnia 565; Na Kolonii 790; Kobyłczyna Wyżnia 630.

Mycobilimbia sabuletorum (Schreb.) Hafellner [= Bacidia sabuletorum (Schreb.) Lettau] - Omszała wapnista gleba oraz omszałe pnie buków.

2 stan. pot. Adamczyków 400; g. Mogielnica 1150.

Mycoblastus sanguinarius (L.) Norman - Kora starych świerków w naturalnych lasach.

1 stan. g. Mogielica 1160.

Mycocalicium subtile (Pers.) Szat. [ = M. minutellum (Ach.) Nadv.] - Murszejące pniaki iglaste.

4 stan. Luboński Potok 585; g. Ćwilin 985, 1020; g. Łopień 850.

Neofuscellia loxodes (Nyl.) Essl. [ = Parmelia isidiotyla Nyl.] - Bezwapienne piaskowce (skałki, gołoborza); miejsca suche i widne.

4 stan. podnóże g. Bydłoniowa 430; g. Turnia 565; m. Bulandami a Chlipałami 500; Kozłówka 450.

Ochrolechia androgyna (Hoffm.) Arnold - Kora starych buków w naturalnych lasach.

5 stan. g. Śnieżnica 970; Polana Skalne 1000; g. Mogielica 1040, 1150; g. Modyń 1025.

O. arborea (Kreyer) Almb. - Na korze wierzb wolno rosnących.

1 stan. pot. Szarków 400 .

O. lactea (L.) Hafellner \& Matzer [= Pertusaria lactea (L.) Arnold] - Bezwapienne piaskowce (skały, stosy kamieni, gołoborza, luźne murki); miejsca suche i widne.

11 stan. g. Bydłoniowa 430, 640; g. Śnieżnica 950; pot. Rosochaniec 575; g. Turnia 565; m. Bulandami a Chlipałami 500; Kurzejówka 515; g. Bystra 660; Załpeński Potok 400; Na Korabiu 705; Na Kolonii 740.

O. pallescens (L.) Massal. - Kora klonu pospolitego wolno rosnącego.

1 stan. Na Kolonii 630.

O. subviridis (Höeg) Erichs. - Na korze drzew liściastych wolno rosnących.

2 stan. Biale $610 ; \mathrm{m}$. Dobra a Tymbarkiem 450.

O. turneri (Sm. in Sm. \& Sowerb.) Hasselrot [= Pertusaria leprarioides auct.]

- Kora drzew liściastych (wierzby).

1 stan. Pietoniówka 445. 
Omphalina umbellifera (L., Fr.) Quélet $[=$ Botrydina vulgaris Bréb. $]$ - Butwiejące pniaki; miejsca cieniste.

4 stan. Jakubiaki 530; g. Kotelnica 665; Polana Skalne 1000; g. Tokoń 880.

Opegrapha gyrocarpa Flot. - Zacienione, bezwapienne skałki piaskowcowe, na powierzchniach pionowych; w stanie płonnym.

4 stan. pot. Rosochaniec 575; pol. Piekło 620; g. Bystra Góra 660; g. Kuklacz 660.

O. rufescens Pers. - Kora drzew liściastych.

5 stan. Wilczakowa 510; pot. Kozieniec 520; Bruski 720; g. Mogielica 900; Potoki 550.

O. varia Pers. $[=O$. lichenoides Pers. $]$ - Kora starych buków w naturalnych lasach.

6 stan. Polana Skalne 1000; g. Mogielica 900, 1150; pot. Mogielica 725, 1000; podnóże g. Zamczysko 325.

O. viridis (Pers ex Ach.) Behlen \& Desberger - Kora starych buków w naturalnych lasach.

1 stan. pot. Mogielica 725 .

O. vulgata Ach. $[=O$. devulgata $\mathrm{Nyl}$.$] - Kora starych drzew liściastych (buki)$ i iglastych (jodły) w naturalnych lasach.

2 stan. g. Śnieżnica 970; poniżej Łąki 840.

O. v. var. subsiderella $\mathrm{Nyl}$. $[=$ O. subsiderella $(\mathrm{Nyl}$.) Arnold $]$ - Kora olch. 1 stan. Białe 610.

Pannaria leucophaea (Vahl) Jørg. [=P. microphylla (Sw.) Delise in Bory $]$ - Bezwapienne piaskowce (pionowe skałki, gołoborza); najczęściej miejsca suche i cieniste.

3 stan. g. Turnia 565; pot. Szczawa 560; Kurzejówka 515.

$P$. pezizoides (Weber) Trevis. - Omszałe głazy piaskowcowe.

1 stan. pot. Adamczyków 600 .

Parmelia saxatilis (L.) Ach. - Kora drzew liściastych, niekiedy iglastych.

31 stan. Kubińcowa 395; Dobrzany 645; Potoczki 580; Dudziki 500; g. Śnieżnica 1005; g. Ćwilin 985; Polana Skalne 1000; g. Krzysztonów 985, 1005; Białe, 610; g. Łopień 840; g. Mogielica 900, 1040, 1150, 1160; Rybny Potok 450; Kuźle 505; g. Turnia 560; g. Modyń 985, 1025; Moczarki 385; Kurczaby 500; Brzeg 570; g. Sikorzec 800; Łąki 570; Pod Rębiskiem 580; g. Łyżka 765; g. Sałasz 895; Przyszowa 440; Kobyłczyna Niżna 350; Burdak 490.

P. sulcata Taylor - Kora drzew liściastych, przydrożnych lub wolno rosnących. 71 stan. Siepańcowa 460; Lubień 360; Janówka 460; Śmietanowa 460; Michalaki 635; Biedaki 470; Potok 400; pot. Szarków 385; Dudziki 490; Kopytki 500; Kuczaje 545; Płoszczyce 605; Szczypty 650; Zawady 520; Bruski 625; Dobra 570; Rola 510; g. Krzysztonów 985; g. Mogielica 1040; pot. Mogielica 765; Pietoniówka 445; Zaświercze 635; Zagórze 600; g. Hala 905; Kuźle 505; Bednarki 470; Podlesie 420; pot. Szczawa 560; Rupniów 400; Dwór 385; Stara Karczma 450; g. Modyń 1025; Byniowa 650; Moczarki 385, 405; Szara Wieś 460; Ogrelówka 450; Limanowa 425; dol. Jabłoniec 385; Załpa 375; Kurczaby 500; Brzeg 570; Podokowaniec 720; Kęcina 575; m. Mordarką a Limanową 450; dol. Roztocze 610; Ląki 570; Tokarze 680; Kunówka 590; Pod Rębiskiem 580; dol. Rozdziele 325, 335; Głowaczyzna 565; Jaworzna 425; dol. Roztoki 550; Łukowica 510; Na Padole 600; Świdnik 390; m. Cabałówką a Przyszową 445; dol. Krosnej 335; Dobrocierz 480; Kobyłczyna Niżna 400; Litacz 610; Soślina 440; g. Babia Góra 680; pot. Suchy 480; pot. Brzeźna 430, 435, 465; Burdak 470; Tłoki 270.

Parmelina tiliacea (Hoffm.) Hale [= Parmelia scortea (Ach.) Ach.] - Kora drzew liściastych, zwykle rosnących wolno lub koło dróg.

18 stan. Karpieńcowa 545; Antosy 485; Dudziki 490; Kuczaje 545; Płoszczyce 600; Folwark 500; Rubisie 525; Dobra 470; Tymbark 645; m. Bulandami a Chlipałami 500; Rozpicki Potok 340; Pod Rębiskiem 580; Rozpite 495; Jaworzna 425; Na Padole 600; Przyszowa 440; Na Kolonii 680; Kobyłczyna Niżna 400. 
Parmeliopsis ambigua (Wulfen) Nyl. - Kora drzew iglastych i liściastych oraz murszejące drewno pniaków.

52 stan. g. Luboń Mały 875; Krzysie 700; Luboński Potok 540, 560; g. Luboń Wielki 835; g. Mały Groń 590; g. Mała Góra 740; Zarębie 480; m. g. Adamczykowa a Piwowarami 560; g. Lubogoszcz 855, 900; g. Śnieżnica 1005; g. Wróble 665; g. Ćwilin 1025, 1030; pot. Rosochaniec 615; Smolenie 650; g. Jasień 1030; Bruski 720; g. Krzysztonów 985; g. Łopień 885; g. Mogielica 1075, 1165; m. g. Świnia Góra a Wieszkami 560; pot. Rybny Potok 550; g. Wiśnia 935; g. Styr 660; g. Mogielica 835; g. Hala 870, 905; pol. Brogi 840; g. Bukowina 790; m. Wierchami a Ślagami 760; Stara Karczma 615; g. Okrąg 565; g. Modyń 835, 1015; g. Ostra 865; g. Jasieńczyk 810; g. Szklarka 600; g. Kuklacz 675; g. Łyżka 685, 765; g. Pępkówka 710; g. Sałasz 895; dol. Krosnej 335; g. Jaworze 915; pot. Suchy 445; g. Chełm 740; m. Litaczem a Łysą Górą 570; g. Szcząb 425, 435.

P. hyperopta (Ach.) Arnold - Murszejące drewno pniaków oraz kora drzew iglastych w naturalnych drzewostanach.

3 stan. g. Jasień 1050; g. Mogielica 1075; g. Modyń 1025.

Peccania coralloides (Massal.) Massal. - Bardzo silnie wapniste piaskowce (pionowe skały); miejsca bardzo suche i silnie nasłonecznione.

1 stan. Niedźwiedź 475.

Peltigera canina (L.) Willd. - Omszała gleba lub omszałe głazy; miejsca suche i widne.

6 stan. Dobrzany 665; Do Uboczy 715; Dobrocierz 500; Zagórze 570; Podpiekle 490; pot.Suchy 420.

P. degeni Gyeln. - U nasady pni buków w naturalnym drzewostanie.

1 stan. pot. Mogielica 725.

P. didactyla (With.) Laundon [ = P. erumpens (Taylor) Elenk.] - Gliniasta gleba na nieużytkach; miejsca suche i widne.

2 stan. Kuce 435; Załpieński Potok 380.

P. horizontalis (Huds.) Baumg. - Gleba w miejscach dość cienistych.

2 stan. Smolenie 590; m. Bulandami a Chlipałami 500.

P. polydactyla (Neck.) Hoffm. - Gliniasta gleba w miejscach dość widnych. 10 stan. g. Mały Groń 720; Zarębie 495; g. Kotelnica 720; g. Ćwilin 670; g. Tokoń 845; m. Burdami a Byniową 600; Załpa Górna 560; g. Pępówka 615; pot. Suchy 445; Kobyłczyna Niżna 310.

P. praetextata (Flk. ex Sommerf.) Zopf $[=P$. subcanina Zopf $]-$ Zacienione i omszałe skały piaskowcowe albo omszałe nasady pni buków.

2 stan. g. Śnieżnica 970; poniżej Polany Skalne 1000.

P. rufescens (Weiss) Humb. - Gliniasta gleba albo omszałe skałki; miejsca suche i widne.

7 stan. g. Luboń Mały 710; Potok 420; poniżej g. Bydłoniowa 430; m. Ciżami a Podgródkiem 410; Kuce 435; Na Snoze 465; pot. Rosochaniec 575.

Pertusaria albescens (Huds.) Choisy \& Werner in Werner $[=P$. discoidea (Pers.) Malme] - Kora drzew liściastych.

10 stan. Siepańcowa 460; Karpieńcowa 545; Wilczakowa 510; Potok 400; Zagórze 600; m. Bulandami a Chlipałami 500; g. Modyń 1025; Jaworzna 425; Na Kolonii 680; Litacz 610.

P. alpina Hepp ex H. E. Ahles - Kora starych buków w naturalnych lasach. 1 stan. g. Modyń 955.

P. amara (Ach.) Nyl. - Kora drzew liściastych i iglastych, również na bezwapiennych piaskowcach (skałki nad potokami, głazy).

33 stan. Siepańcowa 460; Las Luboński 605; g. Luboń Wielki 985; Potok 420; Potoczki 580; g. Śnieżnica 930; Do Uboczy 715; g. Jasień 1050; m. g. Krzysztonów a g. Kutrzyca 980; Polana Skalne 1000; Białe 610; g. Krzysztonów 1005; g. Łopień 900; g. Mogielica 900, 1030, 1150; pot. Mogielica 765, 1040; Czarna Rzeka 
630; g. Hala 870, 905; g. Turnia 560; Kopciówka 650; poniżej przys. Kurzówka 590; g. Modyń 955, 1025; pot. Żmiąca 430, 865; Na Kolonii 680; g. Jaworze 915; przeł. m. g. Jaworze a g. Wielka Góra 675; dol. Krosnej; dol. Potoki 550; Brzeźna 455.

P. corallina (L.) Arnold - Bezwapienne piaskowce (skały, głazy w źródliskach); miejsca widne i słoneczne.

2 stan. u podnóża g. Turnia 560; g. Zamczysko 540.

P. coronata (Ach.) Th. Fr. $[=P$. isidiifera Erichs. $]$ - Kora drzew liściastych (buki, jawory) w naturalnych lasach.

11 stan. g. Śnieżnica 970; g. Jasień 1050; m. g. Kutrzyca a g. Krzysztonów 980; Polana Skalne 1000; g. Łopień 820; g. Mogielica 1150; pot. Mogielica 765; Zaświerszcze 635; g. Modyń 900, 955, 1025.

P. hemisphaerica (Flk.) Erichs. - Kora starych buków w naturalnych drzewostanach.

3 stan. Polana Skalne 1000; g. Mogielica 1150; pot. Mogielica 765.

P. leioplaca DC. in Lam. \& DC. - Kora starych buków w naturalnych drzewostanach.

1 stan. Bruski 720.

P. pertusa (Weigel) Tuck. - Kora starych buków w naturalnych drzewostanach. 10 stan. g. Śnieżnica 970; m. g. Kutrzyca a g. Krzysztonów 980; g. Łopień 900; g. Mogielica 1040, 1150; pot. Mogielica 765; g. Hala 870; g. Modyń 915, 955, 1025.

Phaeophyscia endophoenicea (Harm.) Moberg $[=$ Physcia endophoenicea (Harm.) Santha] - Kora drzew liściastych w widnych miejscach.

5 stan. pot. Bajtków Potok 435; Zaświercze 635; Stara Karczma 450; g. Modyń 1025; pot. Zawada 540.

Ph. nigricans (Flk.) Moberg [= Physcia nigricans (Flk.) Stizenb.] - Kora drzew liściastych oraz obiekty betonowe (obeliski, mury cmentarne, mostki PKP).

8 stan. Kopytki 500; Rola 480; Tokarzówka 695; Byniowa 665; g. Golców 745; pot. Zawada 470; Pisarzowa 475; Litacz 610.

Ph. orbicularis (Neck.) Moberg [= Physcia hueana (Harm.) Rds.] - Kora drzew liściastych, również podłoże betonowe, mury, dachy kapliczek.

54 stan. Siepańcowa 460; Moskałowa 420; Wilczakowa 510; Karpieńcowa 545; Biedaki 470; m. Bajkami a Kołkówką 450; pot. Bajtków Potok 435; Szynaliki 405; Stecki 435; Myszoglądy 455; Janie 440; Dawce 480; Dudziki 500; Kopytki 500; Muszyny 545; Płoszczyce 600; Folwark 500; Panki 775; Rola 480; Pietoniówka 600; Zagórze 600; Bednarki 470; m. Bulandami a Chlipałami 500; Rupniów 400; Dwór 385; Zbludza 490; Wójciczki 435; Paryż 575; Mikołajczyki 415; Byniowa 425; Moczarki 385; Sowliny 385; Załpa 375; Kurczaby 500; Laskowa 330; m. Mordarką a Limanową 450; Potoki 585; Rozdziele 325, 360; Rozpicki Potok 340; Jastrzębie 500; Na Korabiu 705; Łukowica 445, 510; Świdnik 390; Na Kolonii 680; m. Cabałówką a Przyszową 475; Krosna 300; Wola Brzezińska 530; Burdak 470, 495; Tłoki 270; Zawadka 600; Klęczany 295.

Ph. sciastra (Ach.) Moberg $[=$ Physcia sciastra (Ach.) Du Rietz $]$ - Wapniste piaskowce (skałki, głazy i kamienie, dachy kapliczek).

4 stan. podnóże g. Bydłoniowa 430; pot. Bajtków Potok 435; Kozłówka 450; Burdak 495.

Phlyctis argena (Spreng.) Flot. - Kora drzew liściastych (również graby), wyjątkowo na bezwapiennych piaskowcach (kamienie nad rzekami, skałki); miejsca odsłonięte.

49 stan. Kubińcowa 395; Las Luboński 605; Biedaki 470; pot. Szarków 400; g. Wierzbowska 720; Myszoglądy 455; Dudziki 500; g. Śnieżnica 1005; Zawady 520; m. g. Krzysztonów a g. Kutrzyca 980; Białe 610; Rola 480; g. Krzysztonów 985; g. Łopień 900; g. Mogielica 1040; pot. Mogielica 765; Zagórze 600; Czarna Rzeka 630; g. Hala 905; Kuźle 505; Dwór 385; Kozłówka 450; Stara Karczma 480; g. Modyń 915, 955, 985; Moczarki 385; g. Dzielec 615; Limanowa 425; dol. Jabłoniec 385; Załpa 330; dol. Roztoki 610; Łąki 570; Pod Rębiskiem 580; Szarówka 680; Rozpite 495; Jaworze 425; g. Sałasz 895; pot. Zawada 540; 
Na Padole 600; dol. Żmiącej 430; m. g. Jaworze a g. Wielka Góra 675; Sośliny 350; Litacz 610; Wola Brzezińska 470; Kobyłczyna Niżna 310, 350; pot. Suchy 470; poniżej g. Zamczysko 325.

Physcia adscendens (Fr.) Oliv. - Kora drzew liściastych, również podłoże skał wapiennych oraz obiekty betonowe.

47 stan. Siepańcowa 460; Kubińcowa 395; Krętoniowa 440; Luboński Potok 495; Biedaki 470; m. Bajkami a Kołkówką 450; pot. Szarków 385; pot. Bajtków Potok 435; Szynaliki 405; Myszoglądy 455; Janie 440; Dawce 480; Kuczaje 545; Muszyny 545; Płoszczyce 600; Szczypty 650; Zawady 520; Panki 775; Rola 480; Węglarnia 475; Pietoniówka 445; Zaświerszcze 635; m. Bulandami a Chlipałami 500; Rupniów 400; m. Wierchami a Ślagami 760; Wójciczki 435; Paryż 575; Byniowa 425; Moczarki 405; Stara Wieś 460; Załpa 375; m. Mordarką a Limanową 450; g. Kuklacz 575; Potoki 585; Pod Rębiskiem 580; Jastrzębie 500; dol. Rozdziele 325; Zawada 470, 540; Łukowica 510; Przyszowa 440; Świdnik 390;Wola Brzezińska 530; Zawadka 600; Łazy 540; Klęczany 295; poniżej g. Zamczysko 325.

Ph. aipolia (Ehrh. ex Humb.) Fünr. - Kora drzew liściastych wolno rosnących albo koło dróg.

22 stan. Siepańcowa 460; Kubińcowa 395; Krętoniowa 440; Karpieńcowa 545; Biedaki 470; Kiece 550; Bajki 450; Szarków 400; pot. Bajtków Potok 435; Kuce 410; Potoczki 560; Szynaliki 405; Stecki 435; Myszoglądy 455; Janie 440; Wierzbanica 545; Dobra 470; Rola 510; Kurczaby 500; Kęcina 575; Łukowica 445; Mordarka 475.

Ph. caesia (Hoffm.) Frnr. - Wapniste lub bezwapienne piaskowce (skałki, głazy, luźne murki, stosy kamieni), niekiedy podłoże betonowe; miejsca suche i widne. 16 stan. pot. Śmigawka 510; Potok 420; poniżej g. Bydłoniowa 430; Dawce 580; Muszyny 545; Rubisie 625; Fudaleje 575; Rola 480; Czarna Rzeka 600; podnóże g. Turnia 520; pot. Mroczkówki 380; Kozłówka 450; dol. Rozdziele 360; pot. Zawada 470; pot. Suchy 420; Męcina 380.

Ph. dubia (Hoffm.) Lett. $[=$ Ph. teretiuscula (Ach.) Lynge] - Skały piaskowcowe; miejsca widne i suche.

4 stan. poniżej g. Bydłoniowa 430; Tokarzówka 695; g. Turnia 565; Kozłówka 450.

Ph. stellaris (L.) Nyl. - Kora drzew liściastych wolno rosnących lub koło dróg. 14 stan. Lubień 360; Śmietanowa 460; Płoszczyce 605; Folwark 500; Zawady 520; Rola 480; Moczarki 405; Łukowica 445; dol. Rozdziele 325; m. Cabałówką a Przyszową 445; Burdak 490; Brzeźna 465; pot. Brzeźna 435; Klęczany 295.

Ph. tenella (Scop.) DC. in Lam. \& DC. - Kora drzew liściastych wolno rosnących albo koło dróg.

29 stan. Sierpańcowa 460; Kubińcowa 395; Krętoniowa 440; Śmietanowa 460; Janówka 460; Biedaki 470; pot. Szarków 400; Janie 440; Muszyny 545; Brogi 565; Płoszczyce 600; Folwark 500; Węglarnia 475; Rybny Potok 450; Dwór 385; Wójciczki 435; Stara Karczma 450; Załpa 375; Kurczaby 500; m. Mordarką a Limanową 450; Tokarze 680; Pod Rębiskiem 580; dol. Krosnej 350; Krosna 300; g. Soślina 440; Kobyłczyna Niżna 350; pot. Suchy 480; pot. Brzeźna 465; Troki 270.

Ph. wainioi Räs. - Bezwapienne piaskowce (skałki, głazy), również kora drzew liściastych (jesiony); suche i widne miejsca.

5 stan. Kuce 390; podnóże g. Turnia 560; Zbludza 490; Kozłówka 450; g. Byniowa 665.

\section{Physconia distorta (With.) Laundon [= Physcia pulverulenta (Hoffm.) Frnr.]}

- Kora drzew liściastych wolno rosnących albo koło dróg.

38 stan. Siepańcowa 460; Luboński Potok 495; Wilczakowa 510; Janówka 460; Śmietanowa 460; Karpieńcowa 545; Biedaki 470; Kiece 550; m. Bajkami a Kołkówką 450; Potok 400; pot. Bajtków Potok 435; Kuce 410; Potoczki 560; pot. Szarków 400; Szynaliki 405; Janie 440; Dawce 480; Płoszczyce 600, 605; Folwark 500; Rubisie 525; Panki 775; Dobra 470; Rola 480; Pieconiówka 455; pot. Szczawa 560; Wójciaki 435; Stara Karczma 450; Byniowa 650; Załpa 375; Laskowa 330; Mordarka 475; Pod Rębiskiem 580; Jastrzębie 555; m. g. Jaworze a g. Wielka Góra 675; g. Soślina 440; pot. Suchy 480; Tłoki 270.

Ph. enteroxantha (Nyl.) Poelt - Kora drzew liściastych wolno rosnących lub koło dróg. 
10 stan. pot. Szarków 400; Szynaliki 405; pot. Rybny Potok 450; Zaświercze 635; Bednarki 470; Limanowa 455; m. Mordarką a Limanową 450; Laskowa 330; g. Soślina 440; Kobyłczyna Niżna 350.

Ph. perisidiosa (Erichs.) Moberg [= Physcia farrea auct. $]$ - Kora drzew liściastych rosnących koło dróg.

3 stan. Wilczakowa 510; Folwark 500; g. Soślina 440.

Placynthiella oligotropha (Laundon) Coppins \& P. James [= Lecidea uliginosa auct.] - Humusowa gleba w miejscach suchych i widnych.

1 stan. g. Łysa Góra 560.

P. uliginosa (Schrad.) Coppins \& P. James [= Lecidea humosa (Hoffm.) Leight.] - Gliniasta lub humusowa gleba, murszejące drewno pniaków. Być może wiele z wymienionych poniżej stanowisk należy jednak do P. icmalea (Ach.) Coppins \& P. James.

46 stan. g. Luboń Mały 870; Luboński Potok 520; g. Mały Groń 720; g. Kamionka 585; Dobrzany 665; g. Bydłoniowa 640; m. g. Adamczykowa a Piwowarami 560; g. Kotelnica 665; pot. Dawce 550; Dymasy 550; Drągówka 670; Wierzbanice 575; g. Śnieżnica 1005; Wróble 580; g. Ćwilin 1030; pot. Rosochaniec 625; Przysłopek 815; g. Jasień 1030; m. Dobrą a g. Łopień 530; g. Łopień 780; Rybny Potok 510; g. Wiśnia 935; Czarna Rzeka 600; g. Mogielica 945; g. Hala 905; pol. Brogi 840; Nowy Dwór 455; g. Tokoń 925; m. Przysłopem a Wierzyką 775; m. Burdami a g. Byniowa 625; g. Ostra 915; dol. Wilczy Rynek 480; Nagórze 640; g. Jasieńczyk 860; Jeżowa Woda 870; Kęcina 775; g. Pępówka 770; g. Szkiełek 750; pot. Na Padole 515; g. Kobyła 600; Kobyłczyna 630; Zagórze 540; Kobyłczyna Niżna 400; pot. Brzeźna 480; g. Chełm 730; Wierzchowina 460.

Placynthium nigrum (Huds.) Gray - Wapniste piaskowce (skałki nad potokami, głazy i kamienie); miejsca dość widne i suche.

11 stan. m. Ciżami a Podgródkiem 410; Gronoszowa 415; Niedźwiedź 475; Wróble 580; Smolenie 630; Czarna Rzeka 630; podnóże g. Turnia 560; pot. Szczawa 560; pot. Suchy 420; Tłoki 270; g. Zamczysko 510.

Platismatia glauca (L.) W. Culb. \& C. Culb. [= Cetraria glauca (L.) Ach.] - Kora drzew liściastych oraz iglstych.

15 stan. g. Luboń Wielki 985; Biedaki 470; Polana Skalne 1000; g. Krzysztonów 985; g. Łopie 880; pol. Wyśnikówka 1100; g. Mogielica 835, 900, 1160; g. Modyń 915, 955, 985, 1025; g. Sałasz 895; Zagórze 570.

Polysporina lapponica (Ach. ex Schaer.) Degel. [ = Acarospora silesiaca ( $\mathrm{H}$. Magn.) H. Magn.] - Bezwapienne piaskowce (stosy kamieni, luźne murki, głazy); miesca suche i widne.

21 stan. Filipcowa 580; g. Mały Groń 575; Kozówka 580; Zarębie 370; Sowy 605; g. Lubogoszcz 965; Ciastonie 710; g. Zęsów 685; m. Tymbarkiem a Górami 645; Kozłówka 450; g. Pasierbiecka Góra 730; Wierzch Góry 700; g. Ostra 870; Jeżowa Woda 865; Kęcina 645; g. Pępówka 725; g. Szklarka 725; Jaworze 675; Na Kolonii 790; g. Chełm 750; Klenie 660.

P. simplex (Davies) Vězda [= Sarcogyne simplex (Davies) Nyl.] - Bezwapienne piaskowce (stosy kamieni, luźne murki, skałki); miejsca suche i widne.

22 stan. Filipcowa 580; las Mocarze 500; g. Lubogoszcz 965; g. Śnieżnica 900; Zęsów 685; Piekiełko 375; H. Modyń 1015; Młynne 740; g. Ostra 870; Jeżowa Woda 865; g. Sikorzec 800; g. Wysoki Dzielec 680; g. Szkiełek 740; g. Kiklówka 645; g. Pępówka 725; Szałas 845; Zagórze 680; Kobyłczyna 675; Granica 715; g. Babia Góra 685, 720; g. Chelm 770.

Porpidia crustulata (Ach.) Hertel \& Knoph in Hertel [ = Lecidea crustulata (Ach.) Spreng.] - Bezwapienne piaskowce (stosy kamieni, luźne murki, kamieńce nadrzeczne, skałki); miejsca suche i widne.

65 stan. g. Luboń Mały 870; Pokrzywnik 875; g. Mały Groń 720; Sutory 470; g. Mała Góra 695; Kiece 550; Dobrzany 665; Potok 420; Zarębie 370, 495; m. pot. Szarków a g. Okrągła 455; g. Bydłoniowa 640; las Mocarze 500; pot. Szarków 390; m. g. Adamczykowa a Piwowarami 560; g. Kotelnica 665; g. Witów 
680; Dawce 580; Do Uboczy 750; Wróble 580; m. Łąkami a g. Cyrki 830; pot. Rosochaniec 625; Pod Górą 615; Fudaleje 575; g. Myszyca 865; pol. Janiowa 800; g. Krzysztonów 1005; m. g. Wiśnia a Rychlikiem 880; g. Łopień 780; g. Hala 910; Sorysz 740; Nowy Dwór 455; Bukowina 790; Lemirze 385; g. Tokoń 825, 925; Zbludza 480; g. Okrąg 600; pot. Byniowa 545; Pod Modyniem 880; Ogrelówka 385; g. Widoma 570; g. Golców 650; g. Szkiełek 740; g. Sikorzec 800; Załpeński Potok 380; Potoki 550; g. Okowaniec 790; g. Szklarka 600; Ogrojec 615; g. Łyżka 805; Na Korabiu 685; g. Pępkówka 725, 770; Jaworze 550; Na Kolonii 790; g. Jaworze 915; Zagórze 680; Dobrocierz 500; g. Litacz 625; g. Babia Góra 720; Klenie 625; m. Litaczem a g. Łysa Góra 570; pot. Brzeźna 435.

P. macrocarpa (DC. in Lam. \& DC.) Hertel \& Schwab [= Lecidea macrocarpa (DC. in Lam. \& DC.) Steud.] - Bezwapienne piaskowce (stosy kamieni, luźne murki, gołoborza, skałki nad potokami); miejsca widne i suche.

59 stan. Pokrzywnik 875; g. Mały Groń 720; Karpierzowa 720; Dobrzany 645; g. Bydłoniowa 645; pol. Imka 585; pot. Szarków 390; g. Kotelnica 745; g. Lubogoszcz 925; Filipiaki 630; m. Groń Herbami a Wierzbowską Górą 700; g. Ogorzała 775; Budacze 790; pot. Do Uboczy 750; g. Śnieżnica 775, 970; H. Ćwilin 1010, 1060; pot. Rosochaniec 625; pol. Folwarczna 860; g. Kobylica 880; pol. Łuki 1015; Smolenie 630; pol. Polana Skalne 1050; g. Jasień 1030; Przysłopek 850, 870; g., Myszyca 865; g. Krzysztonów 1005; g. Mogielnica 980, 1150; pol. Wyśnikówka 1100; g. Łopień 780; m. g. Wiśnia a g. Cyrla 690; g. Hala 910; g. Turnia 520; H. Modyń 1015; g. Jasieńczyk 830, 860; g. Ostra 865; Jeżowa Woda 865; g. Szkiełek 700, 740, 745; g. Sikorzec 800; Załpeński Potok 415; Sarczyn 555; g. Łyżka 805; Jaworzna 575, 640; Na Korabiu 705; g. Sałasz 875; Na Padole 515; pol. Żmiąca 805; Na Kolonii 790; Kobyłczyna 630; Granica 715; g. Chelm 745; Klenie 685.

P. speirea (Ach.) Krempelh. [= Lecidea speirea (Ach.) Ach.] - Bezwapienne piaskowce; zacienione skałki nad potokami.

3 stan. g. Śnieżnica 970; pot. Rosochaniec 575; Chyszówki 580.

P. tuberculosa (Sm. in Sm. \& Sowerby) Hertel \& Knoph in Hertel [ = Lecidea tumida Massal.] - Bezwapienne piaskowce (stosy kamieni, luźne murki, gołoborza, skałki); miejsca suche i widne, niekiedy wilgotne i lekko cieniste; prawie zawsze w stanie płonnym.

37 stan. g. Cymbałowa 570; g. Bydłoniowa 620; las Mocarze 500; pot. Szarków 390; Sowy 640; Filipiaki 630; poniżej g. Kocia Górka 575; g. Czarny Dział 640; g. Ogorzała 775, 800; H. Ćwilin 1060; g. Śnieżnica 775; pot. Rosochaniec 625; g. Kobylica 880; pol. Łuki 1000; Przysłopek 870; Polana Skalne 1050; pol. Kozice 860; H. Mogielica 1060, 1100; g. Cyrla 690; g. Styr 660; g. Hajdowska Góra 800; H. Modyń 1015; g. Kamionna 780; g. Ostra 865, 870; Jeżowa Woda 865; g. Szkiełek 720, 740; Rozpite 475; Na Korabiu 705; g. Pępówka 750; Jaworzna 675; Na Kolonii 740; Kobyłczyna 630; Klenie 685.

Protoblastenia rupestris (Scop.) Stnr. - Wapniste i bezwapienne piaskowce (skałki nad potokami, głazy) oraz podłoże betonowe (mostki kolejowe).

21 stan. m. Ciżami a Podgródkiem 410; Gronoszowa 415; Krzynów 615; Niedźwiedź 475; Las Puciaki 500; Wróble 580; Rubisie 625; pot. Rosochaniec 575; Fudaleje 570; Czarna Rzeka 630; Lemirze 385; Węglarka 380; Kozłówka 450; pot. Byniowa 425; Strzeszyce 305; Pisarzowa 475; Gajduszowiec 285; pot. Suchy 420; Sadowa 285; Tłoki 270; g. Zamczysko 480.

Protoparmelia badia (Hoffm.) Hafellner [=Lecanora badia (Hoffm.) Ach.] - Bezwapienne piaskowce (stosy kamieni, luźne murki, głazy, gołoborza); miejsca suche i widne.

20 stan. Dobrzany 645; g. Bydłoniowa 640; g. Gródek 500; Sowy 640; g. Lubogoszcz 925, 965; g. Czarny Dział 640; g. Ogorzała 775; H. Ćwilin 1060; pol. Łuki 1000; Przysłopek 870; pol. Kozice 860; polanki poniżej g. Cyrla 690; g. Turnia 520, 565; H. Modyń 1015; g. Sałasz 875; g. Szkiełek 720; g. Jaworze 810; g. Chełm 750.

Pseudevernia furfuracea (L.) Zopf - Kora drzew iglastych i liściastych.

40 stan. Luboński Potok 560; Zarębie 480; Szewczyki 620; Kozówka 615; las Mocarze 500; Potoczki 560; 
g. Czarny Dział 640; Kopytki 500; g. Cyrki 640; g. Ćwilin 985, 1025, 1030; m. Łąkami a g. Cyrki 840; pot. Rosochaniec 615; pol. Łuki 1015; Dudziki 500; g. Łopień 770; pol. Jaworze 945; pol. Wyśnikówka 1100; Zagórze 600; Czarna Rzeka 630; g. Mogielica 835; Kuźle 505; Bukowina 790; g. Modyń 955, 1025; Paryż 575; g. Okrąg 565; Jeżowa Woda 865; Granica 580; g. Sikorzec 800; Łąki 570; g. Kuklacz 650, 670; Zagórze 570; g. Babia Góra 680; g. Chełm 750, 765; Klenie 615; pot. Brzeźna 435.

Pseudosagedia aenea (Wallr.) Hafellner \& Kalb $[=$ Porina carpinea (Pers. ex Ach.) A. Zahlbr.] - Kora drzew liściastych (buki), zwykle u nasady pni; miejsca suche lub lekko wilgotne.

1 stan. g. Luboń Wielki 985.

P. chlorotica (Ach.) Hafellner \& Kalb [= Porina chlorotica (Ach.) Mll. Arg. $]$ - Bezwapienne piaskowce (wilgotne kamienie w łożyskach potoków, zacienione skałki).

3 stan. g. Lubogoszcz 925, 950; g. Mogielica 1030.

P. guentheri (Flot.) Hafellner \& Kalb [= Porina guentheri (Flot.) A. Zahlbr. $]$ - Bezwapienne piaskowce (skałki lekko zacienione).

1 stan. g. Śnieżnica 970.

Psilolechia lucida (Ach.) Choisy [ = Lecidea lucida (Ach.) Ach. $]$ - Bezwapienne piaskowce (luźne murki, stosy kamieni); miejsca suche i widne.

5 stan. Dobrzany 645; g. Bydłoniowa 430; pot. Rosochaniec 625; g. Zbludzkie Wierchy 750; g. Sałasz 875.

Psorotichia schaereri (Massal.) Arnold - Węglanowe piaskowce (skałki); miejsca suche i widne.

1 stan. Zamczysko 480.

Punctelia subrudecta (Nyl.) Krog [= Parmelia dubia (Wulf. in Jacq.) Schaer.] - Kora drzew liściastych wolno rosnących lub koło dróg.

12 stan. Potok 400; Dudziki 500; Płoszczyce 605; Pietoniówka 445; Zagórze 600; Kuźle 505; Podlesie 420; Moczarki 385; Kęcina 575; Pod Rębiskiem 580; Przyszowa 440; Dobrocierz 480.

Pycnothelia papillaria (Ehrh.) Dufour - Sucha, gliniasta gleba na nieużytkach i koło ścieżek.

10 stan. g. Cymbałowa 540; g. Mała Góra 695; Sowy 650; g. Cyrki 640; g. Jasień 920; pol. Janiowa 820; g. Groń 720; m. Wierchami a Ślagami 760; Lasek 595; g. Kopiec 570.

Pyrenula laevigata (Pers.) Arnold - Kora starych buków w naturalnych lasach. 3 stan. Bruski 720; g. Łopień 820; pot. Mogielica 1040.

P. nitida (Weig.) Ach. - Kora starych buków, wyjątkowo olch u nasady pni, w naturalnych lasach.

15 stan. m. g. Mała Góra a g. Szczebel 885; g. Lubogoszcz 900; g. Śnieżnica 930, 960; Polana Skalne 1000; Bruski 720; Białe 610; g. Mogielica 900, 1150; pot. Mogielica 765, 1000; g. Modyń 915, 955, 1025; g. Chełm 765 .

Ramalina farinacea (L.) Ach. - Kora drzew liściastych wolno rosnących lub koło dróg.

4 stan. g. Mogielnica 1150; g. Modyń 955; Potoki 550; Sadowa 425.

R. intermedia Del. - Zacienione, pionowe skały piaskowcowe o dużej zawartości węglanu wapnia.

1 stan. g. Śnieżnica 970.

R. pollinaria (Westr.) Ach. - Kora drzew liściastych (lipy).

1 stan. Kuźle 505.

Rhizocarpon badioatrum (Flk. ex Spreng.) Th. Fr. - Bezwapienne piaskowce (skałki i głazy, gołoborza); miejsca suche i widne.

3 stan. poniżej g. Bydłoniowej 430; g. Turnia 565; m. Bulandami a Chlipałami 500. 
Rh. distinctum Th. Fr. - Bezwapienne piaskowce (stosy kamieni, luźne murki, głazy i kamienie, gołoborza); miejsca suche i widne.

47 stan. pot. Śmigawka 510; g. Mały Groń 575; g. Mała Góra 800; Dobrzany 645; Potok 420; g. Lubogoszcz 965; m. Groń Herbami a Wierzchowską Górą 700; g. Wierzbanowska 715; g. Czarny Dział 640; g. Ogorzała 775; g. Śnieżnica 775; pot. Rosochaniec 625; Pod Górą 615; pol. Łuki 1015; Bruski 600; Polana Skalne 1050; pol. Kozice 865; pol. Jaworze 945; Tokarzówka 695; g. Turnia 565; Zęzów 685; Tymbark 645; m. Bulandami a Chlipałami 500; Wierzch Góry 700; Młynne 740; Pod Modyniem 825; g. Kamionna 780; g. Jasieńczyk 810; g. Golców 730; Jeżowa Woda 865; g. Szkiełek 740; g. Sikorzec 800; Kęcina 645; Rozpite 475; Sarczyn 555; Jaworzna 660; Na Korabiu 705; Szałas 845; g. Pępkówka 750; Na Padole 700; Kobyłczyna 630; Babia Góra 685; pot. Suchy 420; g. Chełm 745, 765, 770; Klenie 660.

Rh. geographicum (L.) DC. subsp. geographicum - Bezwapienne piaskowce (gołoborza, luźne murki, stosy kamieni); miejsca suche i widne.

5 stan. g. Wierzbanowska 715; g. Turnia 565; H. Modyń 1015; Na Kolonii 790; g. Chełm 750.

Rh. geographicum (L.) DC. subsp. lindsayanum (Räs.) $[=R h$. lindsayanum Räs., $R h$. riparium Räs.] - Bezwapienne piaskowce (stosy kamieni, luźne murki, skałki, gołoborza); miejsca suche i widne.

69 stan. pot. Śmigawka 510; g. Cymbałowa 570; Karpierzowa 720; g. Mała Góra 695; Dobrzany 645; g. Bydłoniowa 430, 640; Sowy 640; g. Lubogoszcz 925, 965; Filipiaki 630; m. Groń Herbami a Wierzbowską Górą 700; g. Wierzbanowska 715; g. Czarny Dział 640; g. Ogorzała 775, 800; Budacze 790; g. Ćwilin 1060; pot. Rosochaniec 575, 625; g. Kobylica 880; pol. Łuki 1000, 1015; Przysłopek 870; Fudaleje 575; Bruski 600; Polana Skalne 1050; g. Krzysztonów 1005; pol. Kozice 860; g. Łopień 780; g. Mogielica 1165; H. Mogielica 1060, 1100; polanki poniżej g. Cyrla 690; g. Styr 660; Czarna Rzeka 600; g. Hala 910; g. Turnia 520, 565; pot. Szczawa 560; Kozłówka 450; g. Pasierbiecka Góra 730; Wierzch Góry 700; H. Modyń 1015; Młynne 740; g. Ostra 870; Pod Modyniem 880; blisko g. Ostra 865; g. Jasieńczyk 810; Jeżowa Woda 865; g. Szkiełek 700, 720, 740, 745, 750; Sarczyn 555; Na Korabiu 705; g. Pępówka 750, 770; g. Sałasz 875; Jaworzna 675; Na Kolonii 740; Kobyłczyna 630; Granica 715; g. Babia Góra 685; pot. Suchy 420; g. Chełm 745, 750; Klenie 660 .

Rh. obscuratum (Ach.) Massal. - Bezwapienne piaskowce (stosy kamieni, luźne murki, głazy nad potokami); miejsca suche i widne lub nieco cieniste.

35 stan. g. Mała Góra 695; Dobrzany 645; g. Lubogoszcz 965; Filipiaki 630; g. Witów 710; Las Puciaki 500; g. Czarny Dział 640; Muszyny 545, 790; Do Uboczy 750; H. Ćwilin 1060; g. Śnieżnica 775; pot. Rosochaniec 625, 775; poniżej g. Ćwilin 625; Polana Skalne 1050; g. Krzysztonów 1005; pol. Jaworze 945; g. Łopień 780; polanki poniżej g. Cyrla 690; pot. Szczawa 560; g. Modyń 1015; g. Ostra 870; Pod Modyniem 880; g. Golców 730; Jeżowa Woda 865; g. Okowaniec 790; g. Stawiska 605; Załpeński Potok 415; g. Kuklacz 645; Na Korabiu 705; g. Szkiełek 720; g. Sałasz 875; Jaworzna 640; Kobyłczyna 630.

Rh. petraeum (Wulf.) Massal. [ $=R h$. concentricum auct., Rh. excentricum (Ach.) Arnold] - Wapniste piaskowce (skałki nad potokami, głazy wśród traw); suche, ale nieco cieniste miejsca.

17 stan. Kuce 390; pot. Bajtków Potok 435; Las Puciaki 500; Wróble 580; Do Uboczy 715; pot. Rosochaniec 575; pol. Janiowa 820; pol. Piekło 620; Tokarzówka 695; Czarna Rzeka 630; Węglarka 380; Piekiełko 375; Kozłówka 450; Załpeński Potok 415; g. Chełm 765; pot. Brzeźna 435; g. Zamczysko 540.

Rh. polycarpum (Hepp) Th. Fr. - Bezwapienne piaskowce (stosy kamieni, głazy nad potokami); suche i widne miejsca.

21 stan. g. Mała Góra 695; Filipiaki 630; g. Lubogoszcz 925; m. Groń Herbami a Wierzbowską Górą 700; g. Ogorzała 775; H. Ćwilin 1050; Fudaleje 575; Polana Skalne 1050; pol. Kozice 860; pot. Szczawa 560; H. Modyń 1015; g. Ostra 870; Jeżowa Woda 865; g. Pępówka 725; g. Sałasz 875; Jaworzna 640; pol. Żmiąca 865; Na Kolonii 790; Kobyłczyna 630; Klenie 625, 660.

Rinodina colobina (Ach.) Th. Fr. - Kora drzew liściastych (wierzby) wolno rosnących.

1 stan. Szynaliki 405. 
R. pyrina (Ach.) Arnold - Nagie drewno poręczy mostów. 2 stan. pot. Zawada 470; Klęczany 290.

Sarcogyne regularis Koerb. [ = S. pruinosa auct.] - Wapniste piaskowce (skałki); miejsca suche i widne.

4 stan. poniżej g. Bydłoniowa 430; m. Ciżami a Podgródkiem 410; pot. Suchy 420; g. Zamczysko 540.

Sarcosagium campestre (Fr.) Poetsch \& Schied. [= Biatorella campestris (Fr.) Almq.] - Murszejące pniaki iglaste; miejsca dość cieniste.

6 stan. g. Luboń Wielki 845; g. Cymbałowa 540; g. Kotelnica 665; Dymasy 510; g. Ostra 780; g. Kuklacz 650.

Scoliciosporum chlorococcum (Graewe ex Stenh.) Vézda [ = Bacidia chlorococca (Graewe ex Stenh.) Lettau] - Kora drzew iglstych i liściastych; miejsca dość widne. 97 stan. g. Luboń Mały 710; Krzysie 875; Pokrzywnik 875; g. Mały Groń 590, 720; g. Luboń Wielki 985; pot. Miedziany 700; Michalaki 635; g. Kiczora 720; Dobrzany 665; m. pot. Szarków a g. Okrągła 455; Szewczyki 620; las Mocarze 500; pol. Imka 535; m. g. Adamczykowa a Piwowarami 560; g. Kotelnica 665; g. Lubogoszcz 670, 820, 850, 900; Dymasy 510; g. Dzielec 590; g. Ostra 780; g. Ćwilin 655, 670; Wróble 580 ; g. Śnieżnica 1005; m. g. Łąki a g. Cyrki 840; pol. Folwarczna 860; Kaima 560; Pieżgula 1000; g. Jasień 945; Przysłopek 855; Na Foksowym 810; g. Kostrza 530; Zalesie 550; Tokarzówka 695; podnóże g. Łopień 560; g. Grojec 630; g. Hajdowska Góra 800; pol. Brogi 840; Zęzów 695; Bukowina 790; Nowy Dwór 510; m. Wierchami a Ślagami 760; g. Tokoń 925; g. Pasierbiecka Góra 730; Stara Karczma 595; g. Modyń 835; m. Burdami a Byniową 600; g. Ostra 865, 925; dol. Wilczy Rynek 405, 480; g. Jasieńczyk 810; Jeżowa Woda 870; Jabłoniec 445; Granica 580; Podokowaniec 660; g. Szkiełek 675; Stawiska 650; Załpeński Potok 400; Kęcina 645; g. Kuklacz 625; g. Szklarka 600; Na Jaworzu 720; Kopciówka 650; g. Łyżka 685, 765; Jaworzna 660; g. Pępkówka 615, 750; dol. Jaworznej 350; Na Padole 515; g. Kobyła 600; Kopiec 570; g. Jaworze 870, 915; g. Wielka Góra 775; dol. Krosnej 335, 430; Na Górach 690; g. Kamera 650; Kobyłczyna Niżna 400; Drużków Pusty 450; Klenie 510; g. Chełm 785; g. Litacz 650; g. Gwizdor 590; g. Soślina 565; Podlesie 485; pot. Suchy 445; Wierzchowina 460; pot. Brzeźna 435; Sadowa 390, 425; g. Szcząb 485 .

S. umbrinum (Ach.) Arnold [= Bacidia umbrina (Ach.) Bausch] - Bezwapienne piaskowce (kamienie, luźne murki, głazy nad potokami); miejsca suche i widne. 17 stan. pot. Śmigawka 510; Filipcowa 580; Dobrzany 645; las Mocarze 430; g. Bydłoniowa 430, 620; g. Gródek 500; pot. Rosochaniec 625; Czarna Rzeka 630; Kurzejówka 515; g. Golców 730; Jeżowa Woda 865; g. Szkiełek 740; Na Korabiu 705; Szałas 845; dol. Kamionki Małej 400; Kobyłczyna 630.

Stereocaulon nanodes Tuck. - Bezwapienne piaskowce (stosy kamieni, luźne murki); miejsca suche i widne.

4 stan. Budacze 790; g. Śnieżnica 775; H. Ćwilin 1010, 1060.

Synalissa symphorea (Ach.) Nyl. - Silnie wapniste skały; osuwiska nad brzegami rzek.

1 stan. Sadowa 285.

Tephromela atra (Huds.) Hafellner in Kalb [= Lecanora atra (Huds.) Ach.] - Bezwapienne piaskowce (skałki, stosy kamieni, luźne murki, głazy wśród traw); miejsca suche i widne.

38 stan. pot. Śmigawka 510; Dobrzany 645; Potok 420; g. Bydłoniowa 430, 640; g. Gródek 500; g. Lubogoszcz 950; g. Ogorzała 775; Do Uboczy 715; H. Ćwilin 1060; g. Kobylica 880; g. Cyrla 690; Czarna Rzeka 600, 630; g. Turnia 520, 565; pot. Szczawa 560; g. Bystra Góra 660; Kozłówka 450; g. Kamionna 780; Pod Modyniem 880; g. Jasieńczyk 810, 860; Jeżowa Woda 865; g. Szkiełek 700, 740; Jaworzna 660, 675; Na Korabiu 705; g. Pępówka 750; Na Padole 700; Na Kolonii 740; Kobyłczyna 630; Granica 715; pot. Suchy 480; g. Chełm 745, 750, 765.

Thelidium immersum (Leight.) Mudd - Silnie wapniste piaskowce (pionowe ściany skalne); miejsca suche i widne. 1 stan. g. Zamczysko 480. 
Thelocarpon epibolum Nyl. - Czoła murszejących pniaków świerkowych i jodłowych.

26 stan. g. Luboń Mały 740; Lubień 540; g. Szczebel 810, 840; Zarębie 480; g. Kotelnica 665; g. Lubogoszcz 670; Pod Gronią 660; pol. Dzielec 610; g. Ostra 780; Wróble 665; Łąki 840; Przysłopek 855; Węglarnia 475; g. Mogielica 830, 995, 1040; g. Kamionna 790; dol. Wilczy Rynek 595; g. Szkiełek 675; Zarębki 640; g. Łyżka 685; pot. Brzeźna 480; g. Soślina 560; g. Chełm 740, 765.

Th. intermediellum Nyl. - Butwiejące pniaki iglaste; cieniste miejsca. 2 stan. g. Lubogoszcz 760; g. Wiśnia 935.

Th. laureri (Flot.) Nyl. - Nagie drewno (poręcze mostów, ogrodzenia pól), bezwapienne piaskowce (stosy kamieni, głazy wśród traw).

36 stan. Golcowa 480; Janówka 460; Białkówka 450; pot. Sochów 435; pol. Imka 535; Zarębie 370; Marczaki 395; m. Podgródkiem a Dworem 425; Na Witów 680; Ciastonie 685; m. Kaletami a Putami 495; Kasina Wielka 500; Sutory 470; Dudziki 500; m. Wróblami a g. Ostra 635; Fudaleje 575; Dobra 470; g. Mogielica 825; Zbludza 490; Nagórze 640; m. Słomianą a Stroniami 345; Stara Wieś 460; Laskowa 320; Na Jaworzu 735; dol. Rozdziele 325, 340; Rozpite 485; Na Korabiu 705; Lukowica 470; dol. Kamionki Małej 360; Łagoszówka 305; Żmiąca 295; Krosna 305; Świdnik 355; Łysa Góra 535; Brzeźna 430.

Th. lichenicola (Fuckel) Poelt \& Hafellner [=Ahlesia lichenicola Fuckel $]$ - Murszejące drewno pniaków.

1 stan. pot. Szarków 390.

Thelomma ocellatum (Koerb.) Tibell [ = Cyphelium caliciforme (Flot.) A. Zahlbr.] - Czoła kołków w ogrodzeniu.

2 stan. pot. Szarków 385; Kuźle 505.

Thelotrema lepadinum (Ach.) Ach. - Kora starych buków, rzadziej jodeł, w naturalnych lasach.

3 stan. m. g. Kutrzyca a g. Krzysztonów 980; g. Łopień 900; pot. Mogielica 725.

Thermutis velutina (Ach.) Flot. - Pionowe skałki piaskowcowe nad potokiem; miejsce dość cieniste.

1 stan. Chyszówki 580.

Thrombium epigaeum (Pers.) Wallr. - Gliniasta jałowa gleba; miejsca suche i widne.

23 stan. pot. Miedziany 700; g. Kamionka 585; pot. Szarków 390; pot. Bajtków Potok 445; Przylasek 500; pot. Antosów 540; Pod Gronią 615; g. Hala 870; g. Turnia 520; g. Okrąg 600; Granica 580; g. Sikorzec 780; Załpeński Potok 380; Tokarze 625; g. Łyżka 680; Na Korabiu 685; dol. Kamionki Małej 400; Zagórze 540; g. Kamera 555; g. Litacz 650; g. Soślina 485; pot. Suchy 390; g. Łysa Góra 535.

Toninia aromatica $(\mathrm{Sm}$.$) Massal. - Silnie zwietrzałe wapniste piaskowce (skałki);$ miejsca suche i widne.

1 stan. g. Zamczysko 510, 540.

Trapelia coarctata $(\mathbf{S m}$.$) Choisy in Werner [=$ Lecidea coarctata $(\mathrm{Sm}$.$) Nyl.]$ - Bezwapienne piaskowce (skałki, głazy i kamienie wśród trawy); miejsca suche $\mathrm{i}$ widne lub lekko wilgotne $\mathrm{i}$ cieniste.

44 stan. Górniówka 405; g. Mała Góra 770; Łabuzy 500; Zarębki 370; pot. Szarków 390; g. Kotelnica 720, 745; pot. Głębowski 505; g. Kocia Górka 610; g. Spyrkowa 715; g. Witów 710; Sutory 470; Sępki 520; m. g. Wróble a g. Ostra 650; g. Śnieżnica 1005; Do Uboczy 760; H. Ćwilin 1010; m. Łąkami a g. Cyrki 740; Pod Górą 615; g. Ćwilin 625; Fudaleje 575; Polana Skalne 1050; m. Dobrą a g. Łopień 530; Sorysz 740; m. g. Rydznik a g. Wiśnia 880; g. Mogielica 850; Nowy Dwór 510; Byniowa 545; Pod Modyniem 825; Załpeński Potok 380; Potoki 550; Rozpite 475; Na Korabiu 705; g. Pępówka 570, 770; Na Padole 515; g. Jaworze 915; Dobrocierz 500; Podpiekle 490; g. Litacz 650; pot. Brzeźna 455; Kobyłczyna Niżna 335; Sadowa 285, 415. 
T. obtegens (Th. Fr.) Hertel - Bezwapienne piaskowce (stosy kamieni, luźne murki); miejsca suche i widne, często nie sprzyjające dla rozwoju porostów.

27 stan. g. Luboń Mały 870; Dobrzany 645; pol. Imka 585; g. Lubogoszcz 950; g. Kocia Górka 610; g. Witów 710; Ciastonie 710; Sawce 580; Budacze 790; g. Ćwilin 1060; g. Śnieżnica 775; Zęzów 685; g. Pasierbiecka Góra 730; H. Modyń 1015; g. Ostra 870; Pod Modyniem 825; g. Stawiska 605; g. Wysoki Dzielec 680; g. Szklarka 600; Rozpite 475; Rosochodka 580; Na Korabiu 795; Szałas 845; Zagórze 680; Kobyłczyna 675 ; g. Babia Góra 720; Klenie 660 .

T. placodioides Coppins \& P. James - Bezwapienne piaskowce (stosy kamieni, głazy wśród traw); gatunek na pewno przeoczony, posiadający dość liczne stanowiska.

1 stan. Kobyłczyna Wyżna 630.

Trapeliopsis flexuosa (Fr.) Coppins \& P. James [= Lecidea flexuosa (Fr.) Nyl.]

- Kora drzew iglastych i liściastych (brzozy), głównie u nasady pni, nagie drewno pniaków, poręczy mostów, kołków ogrodzeń; przeważnie w stanie płonnym.

42 stan. g. Luboń Mały 710; Luboński Potok 520; g. Mały Groń 720; g. Mała Góra 830; Liszki 585; Kozówka 615; pol. Imka 510; pol. Łuki 1015; pot. Szarków 285; m. g. Adamczykowa a Piwowarami 560; g. Lubogoszcz 960; g. Czarny Dział 640; Sutory 470; Do Uboczy 760; Piechówka 570; g. Myszyca 810; g. Łopień 840; g. Krzysztonów 985; g. Mogielica 900, 1165; g. Wiśnia 935; Bukowina 790; Zagórze 600; g. Hala 820; Kuźle 505; Zbludza 490; Moczarki 390; Stara Wieś 460; Kicznia 800; Jeżowa Woda 870; Granica 580; Laskowa 320; g. Szklarka 600; Na Jaworzu 735; Rozpite 485; g. Kobyła 600; g. Jaworze 870; Kobyłczyna Niżna 400; Drużków Pusty 450; pot. Brzeźna 455; m. Litaczem a g. Łysa Góra 570; Brzeźna 430.

T. gelatinosa (Flk.) Coppins \& P. James [= Lecidea gelatinosa Flk.] - Gliniasta gleba, najczęściej na skarpach dróg leśnych; miejsca suche i raczej widne.

18 stan. g. Cymbałowa 540 (z apotecjami); Las Luboński 640; g. Mały Groń 720; pot. Szarków 390; pot. Antosów 540; g. Ćwilin 720 (z apotecjami); Rubisie 655; pot. Jamne 725; pol. Stuse 790; g. Łopień 850; Tokarzówka 710; pot. Mogielica 650; pot. Rybny Potok 510; Tokarzówka 655; g. Mogielica 880, 945; Dębina 580; pot. Brzeźna 480.

T. granulosa (Hoffm.) Lumbsch [= Lecidea granulosa $($ Hoffm.) Ach.] - Humusowa gleba; miejsca suche i widne.

11 stan. g. Mała Góra 695; Ciastonie 700; g. Ćwilin 1000, 1030; Przysłopek 815; g. Mogielica 945; g. Golców 650; g. Okowaniec 790; Jaworzna 640; g. Szkiełek 750; Kobyłczyna 645.

T. viridescens (Schrad.) Coppins \& P. James [=Lecidea viridescens (Schrad.) Ach.] - Butwiejące pniaki drzew iglastych w naturalnych lasach.

1 stan. N stok g. Łopień 710 .

Tuckermanopsis chlorophylla (Willd. in Humb.) Hale [= Cetraria chlorophylla (Willd. in Humb.) Vain.] - Kora drzew iglastych i liściastych.

7 stan. g. Ćwilin 985, 1030; g. Jasień 985; pol. Wyśnikówka 1100; g. Mogielica 835; g. Modyń 1025; g. Sikorzec 800 .

T. sepincola (Ehrh.) Hale [= Cetraria sepincola (Ehrh.) Ach.] - Gałązki usychających świerków.

1 stan. g. Ćwilin 985.

Umbilicaria cylindrica (L.) Delise ex Duby - Bezwapienne piaskowce (głazy wśród traw, stosy kamieni, gołoborza); miejsca suche i widne.

9 stan. Karpierzowa 720; g. Turnia 565; H. Modyń 1015; Pod Modyniem 880; Jeżowa Woda 865; g. Szkietek 720; Na Kolonii 740, 790; g. Chełm 750.

U. deusta (L.) Baumg. - Bezwapienne piaskowce (gołoborza, głazy wśród traw); miejsca suche $\mathrm{i}$ widne.

2 stan. Polanki poniżej g, Cyrla; g. Turnia 565. 
U. polyphylla (L.) Baumg. - Bezwapienne piaskowce (gołoborza); miejsca suche i widne.

2 stan. g. Wierzbanowska 715; g. Turnia 565.

Usnea filipendula Stirt. $[=U$. dasypoga (Ach.) Shirley $]$ - Kora drzew ìglastych (świerki, jodły), niekiedy liściastych (buki).

6 stan. Potok Kozi 540; Polana Skalne 1000; g. Ćwilin 985; pol. Wyśnikówka 1100; g. Mogielica 835, 900.

U. glauca Mot. - Kora starych jodeł w naturalnych lasach.

1 stan. g. Mogielica 835 .

U. hirta (L.) Weber ex Wigg. - Kora drzew liściastych i iglastych (jodły), niekiedy drewno starych płotów.

6 stan. Potok Luboński 560; Bruski 625; g. Mogielica 835; Okrąg 565; Potoki 550; Łąki 570.

U. subfloridana Stirt. $[=U$. $\operatorname{comosa}(\mathrm{L}$.) Vain.] - Kora starych buków. 1 stan. g. Modyń 1025.

Verrucaria anziana Garov. [= Polyblastia anziana (Garov.) Serv.] - Bezwapienne głazy i kamienie piaskowcowe okresowo zalewane wodą w łożyskach potoków. 2 stan. pot. Do Uboczy 760; dol. Kamionki Małej 340.

V. aquatilis Mudd. - Bezwapienne kamienie piaskowcowe zanurzone w czystej wodzie den potoków.

7 stan. Moskałowa 420; pot. Do Uboczy 760; g. Mogielica 1030; pot. Rybny Potok 685; Czarna Rzeka 630, 700; poniżej g. Szklarka 500 .

$V$. denudata Zsch. - Bezwapienne kamienie piaskowcowe zanurzone stale lub okresowo zalewane wodą w łożyskach potoków.

4 stan. pot. Do Uboczy 720; poniżej Polany Skalnej 1000; Czarna Rzeka 700; poniżej g. Szklarka 500.

V. funckii (Spreng. in Funck) A. Zahlbr. $[=V$. silicea Serv. $]$ - Bezwapienne kamienie piaskowcowe okresowo zalewane wodą w łożyskach potoków albo w źródłach.

2 stan. g. Ćwilin 1020; Polana Skalne 1000.

V. fuscella (Turner) Winch - Wapniste piaskowce (skałki) na powierzchniach pionowych; miejsca suche i widne.

5 stan. Kamieniołom pod g. Bydłoniową 430; m. Ciżami a Podgródkiem 410; Niedźwiedź 475; Sadowa 285; g. Zamczysko 465 .

$V$. $\boldsymbol{c f}$. guestphalica Serv. - Bezwapienne skałki i głazy piaskowcowe okresowo zalewane wodą w łożyskach potoków.

4 stan. Lemirze 385; Piekiełko 375; Zbludza 480; dol. Kamionki Małej 340.

V. laevata Auct. - Bezwapienne kamienie piaskowcowe okresowo zalewane wodą w łożyskach potoków.

8 stan. Moskałowa 420; pot. Adamczyków 560; pot. Do Uboczy 760; pot. Rybny Potok 685; Czarna Rzeka 630; Węglarka 380; dol. Kamionki Małej 340; dol. Krosnej 335.

V. nigrescens Pers. - Silnie wapniste piaskowce (pionowe skały).

2 stan. Niedżwiedź 475; Kozłówka 450.

V. rheithrophila Zsch. $[=V$. kernstockii Zsch.] - Bezwapienne kamienie piaskowcowe zanurzone w wodzie źródel.

1 stan. g. Ćwilin 1020.

V. subhydrela Serv. - Bezwapienne kamienie piaskowcowe zanurzone w wodzie potoków.

3 stan. pot. Glębowski 505; dol. Jabłoniec 445; poniżej g. Szklarka 500 . 
V. submauroides Zsch. - Bezwapienne kamienie piaskowcowe okresowo zalewane wodą w łożyskach potoków.

1 stan. pot. Do Uboczy 760 .

V. velana (Massal.) A. Zahlbr. - Silnie wapniste piaskowce (w części nasadowej pionowych ścianek skalnych); miejsca suche, lekko cieniste.

3 stan. Sadowa 285; g. Zamczysko 465, 540.

Vulpicida pinastri (Scop.) Mattson \& M. J. Lai [= Cetraria pinastri (Scop.) Gray] - Kora drzew iglastych, niekiedy liściastych, zwykle u nasady pni oraz murszejące pniaki.

56 stan. g. Luboń Mały 875; Krzysie 700; Luboński Potok 560; Las Luboński 850; g. Mały Groń 590; pol. Rogowcówka 890; pot. Miedziany 820; Zarębie 480; m. pot. Szarków a g. Okrągła 455; Szewczyki 620; las Mocarze 500; pol. Imka 505; m. g. Adamczykowa a Piwowarami 560; g. Lubogoszcz 670, 855, 960; pot. Antosów 670; Ciastonie 700; pot. Wierzbanica 575; g. Śnieżnica 1005; Wróble 665, 580; g. Ćwilin 1025, 1030; pot. Rosochaniec 615; Smolenie 650; Pieżgula 1000; g. Jasień 1030; Bruski 720; g. Łopień 840, 880, 885; g. Krzysztonów 985; pol. Jaworze 945; pol. Wyśnikówka 1100; g. Mogielica 900, 1160; pot. Rybny Potok 550; g. Hala 905; Bukowina 790; g. Modyń 835, 1025; g. Okrąg 565; g. Jasieńczyk 810; Podokowaniec 660; g. Szkiełek 740; g. Szklarka 600; g. Kuklacz 650, 675; g. Łyżka 685, 765; g. Pępkówka 750; g. Kobyła 600; Zagórze 570; pot. Suchy 445; g. Szcząb 485.

Xanthoparmelia conspersa (Ach.) Hale [= Parmelia conspersa (Ach.) Ach.] - Bezwapienne piaskowce (gołoborza, głazy wśród traw, stosy kamieni, luźne murki); miejsca suche i widne.

20 stan. pot. Śmigawka 510; Karpierzowa 720; Dobrzany 645; pot. Szarków 385; poniżej g. Bydłoniowa 430; g. Gródek 490; g. Witów 710; Dawce 580; g. Ogorzała 800; Kopytki 505; Muszyny 545; Kuźle 505; g. Turnia 520, 565; m. Bulandami a Chlipałami 500; Udziele 480; Kozłówka 450; g. Szkiełek 740; dol. Rozdziele 335; g. Pępkówka 710.

Xanthoria candelaria (L.) Th. Fr. - Kora drzew liściastych, zwykle u nasady pni, również nagie drewno kołków z płotów.

6 stan. Byniowa 650; Kopciówka 650; Szarówka 680; Ogrojec 615; Growaczyzna 575; g. Babia Góra 680.

$X$. elegans (Link) Th. Fr. - Obiekty betonowe (mury, mostki przy torach kolejowych).

2 stan. pot. Zawada 470; Pisarzowa 475.

$X$. fallax (Hepp) Arnold - Kora drzew liściastych rosnących koło dróg.

24 stan. Kubińcowa 395; Krętoniowa 440; Wilczakowa 510; Janówka 460; Michalaki 635; Potok 400; Kuce 410; Antosy 485; Szynaliki 405; Do Fudali 740; Kopytki 500; Płoszczyce 600; Rubisie 525; Rola 480; Pietoniówka 450; m. Bulandami a Chlipałami 500; Wójciczki 435; Mikołajczyki 415; Byniowa 650; Załpa 375; Łukowica 445; Litacz 610; Wola Brzezińska 530; Burdak 470.

X. parietina (L.) Th. Fr. - Kora drzew liściastych, deski drewniane oraz obiekty betonowe, głównie koło dróg.

70 stan. Siepańcowa 460; Pasiowa 425; Krętoniowa 440; Śmietanowa 460; Karpieńcowa 545; Biedaki 470; Kiece 550; m. Bajkami a Kołkówką 450; Potok 400; pot. Szarków 385; Kuce 410; Potoczki 580; Szynaliki 405; Myszoglądy 455; Janie 440; Dawce 480; Dudziki 490, 500; Kuczaje 545; Muszyny 545; Płoszczyce 600, 605; Folwark 500; Panki 775; Rola 480; m. Dobrą a g. Łopień 510; Węglarnia 475; Pietoniówka 445; Tokarzówka 695; Sorysz 740; Zagórze 600; pot. Szczawa 560; Rupniów 400; Dwór 385; Wójciaki 435; Zbludza 490; Stara Karczma 495; Paryż 575; pot. Byniowa 425; Byniowa 650; Moczarki 385, 405; Sowliny 385; Stara Wieś 460; Ogrelówka 450; Załpa 375; Zarębki 550; m. Mordarką a Limanową 450; Mordarka 475; m. g. Kuklacz a Zarębkami 575; Potoki 550; Rozpicki Potok 340; Jastrzębie 500; Rozdziele 325; Łukowica 510; Przyszowa 440; Świdnik 390; dol. Żmiącej 340; dol. Krosnej 350; Krosna 305; Litacz 610; Wola Brzezińska 530; g. Soślina 440; pot. Suchy 480; Burdak 470; Brzeźna 440; Tłoki 270; Zawodzie 600; Łazy 540; Klęczany 295. 
$X$. polycarpa (Hoffm.) Th. Fr. ex Rieber - Kora drzew liściastych, zwykle rosnących koło dróg, niekiedy na deskach.

21 stan. Potoczki 560; Folwark 500; Bruski 625; Rola 510; Sorysz 740; Bednarki 470; Podlesie 420; Stara Karczma 495; Paryż 575; Moczarki 405; Zarębki 550; Kęcina 575; dol. Roztoka 610; Tokarze 680; pot. Między Brzegi 520; dol. Rozdziele 325; Głowaczyzna 575; g. Babia Góra 680; pot. Brzeźna 435; Sadowa 425; Zawadka 600.

Xylographa abietina (Pers.) A. Zahlbr. [ $=X$. parallela (Ach.) Behlen \& Desberg] - Stare, butwiejące drewno (kłody, pniaki, dachy starych szop).

4 stan. pol. Łuki 1015; g. Myszyca 865; g. Mogielnica 1165; g. Zbludzkie Wierchy 800.

\section{POROSTY BESKIDU ŻYWIECKIEGO, PASMA JAŁOWCA I MASYWU BABIEJ GÓRY}

\section{Wykaz stanowisk (Ryc. 2, 3) - List of localities (Fig. 2, 3)}

Objaśnienia skrótów (Abbreviations): g. - góra (mountain); H. - hala ( alpine pasture); k. - koło (near); pol. - polana (glade); pot. - potok (stream); przys. - przysiółek (thorp); przeł. - przełęcz (pass); rez. - rezerwat (nature reserve).

Grupa Wielkiej Raczy (WR): 1. g. Abrahamów (Rycerka Górna); 2. przys. Babczonka (Koniaków); 3. g. Bednarów Beskid (Soblówka); 4. g. Beskid Wrzeszcz (Sól); 5. g. Będoszka Wielka (Rycerka Górna); 6. g. Biernatka (Rajcza); 7. g. Bugaj (Rycerka Górna); 8. pol. Bułkowa (Rycerka Górna); 9. przys. Burdówka (Laliki); 10. g. Burów Groń (Rycerka Dolna); 11. pol. Butorza (Zwardoń); 12. pot. Butorza (Zwardoń); 13. rez. Butorza (Zwardoń); 14. pot. Butorzy (Rycerka Górna); 15. pol. Cerla (Młada Hora); 16. przys. Chromiczaki (Nieledwia); 17. przys. Ciapków (Rycerka Górna); 18. pot. Cicha (Ujsoły); 19. pol. Cięcianówka (Rycerka Górna); 20. pot. Czadeczka (Jaworzynka); 21. pot. Czerna (Laliki); 22. pot. Danielka (Ujsoły); 23. przys. Do Staroni (Nieledwia); 24. przys. Dziergasowie (Rycerka Górna); 25. pot. Dzięboki (Młada Hora); 26. pol. Gardasówka (Młada Hora); 27. pot. Głęboki (Sól); 28. przys. Głębokie (Rycerka Górna); 29. pol. Głowa (Soblówka); 30. przys. Graniczne (Zwardoń); 31. g. Groniczek (Zwardoń); 32. przys. Groń (Zwardoń); 33. przys. Gumółki (Zwardoń); 34. przys. Hutyrowa (Soblówka); 35. g. Hutyrów (Rajcza); 36. g. Jaworzyna (Rycerka Górna); 37. g. Jaworzyna k. g. Bugaj (Rycerka Górna); 38. pol. Joneczkowe Rycerki (Rycerka Dolna); 39. pol. Janówka (Rycerka Dolna); 40. pol. Juroszkowa (Młada Hora); 41. pol. Kapotkula (Soblówka); 42. przys. Karchówka (Nieledwia); 43. przys. Kasperki (Laliki); 44. przys. Kępki (Laliki); 45. g. Kiczora (Nieledwia); 46. przys. Kiczora (Nieledwia); 47. g. Kiczorka (Laliki); 48. g. Kiczorka (Młada Hora); 49. g. Kiczorki (Zwardoń); 50. przys. Kiełbasówka (Soblówka); 51. g. Kikula (Rycerka Dolna); 52. przys. Klimas (Sól); 53. g. Klimasy (Pławuchowa); 54. g. Klin (Soblówka); 55. g. Kłokocz (Rycerka Górna); 56. przys. Kolonia (Rycerka Górna); 57. pol. Kołyska (Rycerka Górna); 58. g. Kotarz (Młada Hora); 59. przys. Kotłówka (Zwardoń); 60. pot. Krążelka (Jaworzynka); 61. przys. Królowa (Soblów- 


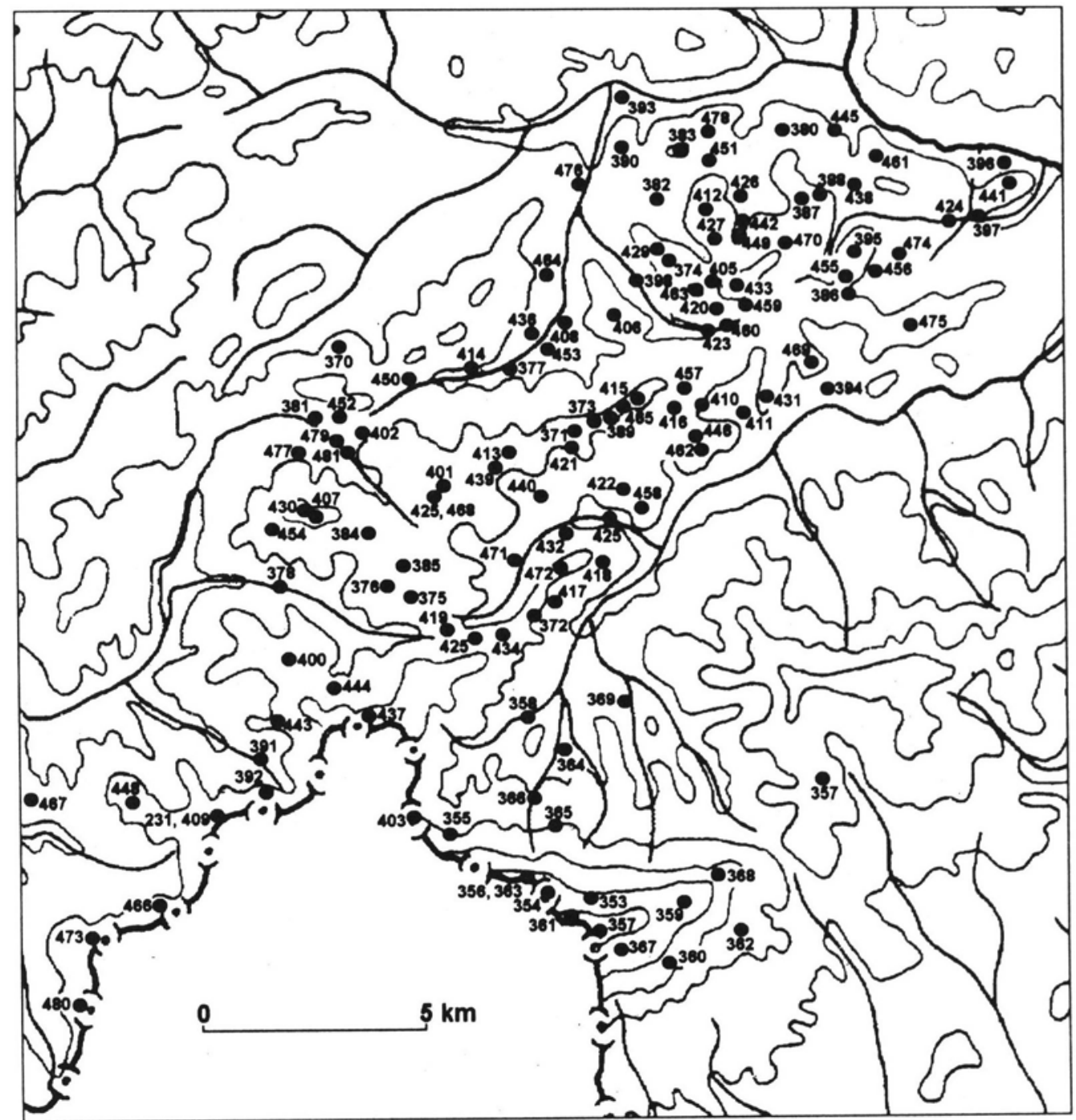

Ryc. 3. Rozmieszczenie stanowisk porostów na Babiej Górze i w Pasmie Jałowca (opracowanie B. MorawSKa-NowaK)

Fig. 3. Distribution of lichen localities in the Babia Góra Massif and the Jałowiec Range (by B. MORAWSKa-NOWAK)

ka); 62. Laliki Wielkie; 63. Las Ku Zimnej Dziurze (Glinka); 64. przys. Lastoczka (Sól); 65. pot. Leżaje (Młada Hora); 66. g. Łysica (Rycerka Dolna); 67. przys. Madejka (Nieledwia); 68. g. Magura (Rycerka Górna); 69. przys. Magura (Rycerka Górna); 70. pol. Majcherowa (Młada Hora); 71. pol. Majów (Młada Hora); 72. pot. Mała Jaworzyna (Rycerka Górna); 73. g. Mała Racza (Rycerka Górna); 74. przys. Mandlówka (Sól); 75. pol. Masarka (Młada Hora); 76. Milówka, przys. Misiorka (Zwardoń); 77. Młada Hora; 78. przys. Młaki (Nieledwia); 79. g. Muńczoł (Ujsoły); 
80. przys. Myto (Zwardoń); 81. pol. Na Praszywce (Rycerka Górna); 82. Nieledwia; 83. pot. Nieledwianka (Milówka); 84. g. Obłaz (Rycerka Górna); 85. przys. Obrot (Zwardoń); 86. g. Ochodzita (Koniaków); 87. przys. Odkrzas (Jaworzynka); 88. przys. Ogrody (Zwardoń); 89. przys. Orawcowa (Zwardoń); 90. rez. Oszus (Soblówka); 91. las Orzeł (Rycerka Górna); 92. g. Oźna (Rycerka Górna); 93. pol. Pawliki (Młada Hora); 94. g. Petrykowa (Młada Hora); 95. przys. Pętkówka (Soblówka); 96. przys. Piekło (Zwardoń); 97. przys. Pietraszyna (Koniaków); 98. pot. Plaskurówka (Rycerka Górna); 99. g. Pleskierówka (Rycerka Górna); 100. przys. Płaskonkowie (Rycerka Dolna); 101. przys. Pławuchowa (Sól); 102. przys. Pochodzita (Koniaków); 103. pol. Pod Raczą (Rycerka Górna); 104. g. Podgórka (Nieledwia); 105. przys. Podścigłów (Rycerka Górna); 106. g. Popręcina (Nieledwia); 107. przys. Popręcinka (Nieledwia); 108. przys. Potok Wielki (Jaworzynka); 109. g. Praszywka (Rycerka Górna); 110. g. Praszywka Mała (Rycerka Górna); 111. przys. Przegibek (Rycerka Górna); 112. pot. Przegibek (Rycerka Dolna); 113. H. Przysłop (Rycerka Górna); 114. g. Przysłop Mały (Rycerka Górna); 115. Przysłop Połucki (Rycerka Górna); 116. g. Przysłop Wielki (Rycerka Górna); 117. g. Rachowiec (Zwardoń); 118. pot. Racza (Rycerka Górna); 119. pot. Radecki (Rycerka Górna); 120. Rajcza; 121. pot. Raztoka (Młada Hora); 122. przys. Raztoki (Rycerka Górna); 123. pol. Raztoki (Rycerka Górna); 124. przys. Rupieńka (Koniaków); 125. pot. Rycerka (Rycerka Dolna); 126. Rycerka Dolna; 127. przys. Rycerki (Rycerka Dolna); 128. g. Ryeerzowa (Soblówka); 129. g. Rycerzowa Wielka (Soblówka); 130. g. Skalanka (Zwardoń); 131. przys. Skomisko (Rycerka Dolna); 132. pol. Skrzadnita (Soblówka); 133. przys. Słonkówka (Soblówka); 134. przys. Smereków Wielki (Soblówka); 135. pot. Smerekówka Mała (Glinka); 136. pot. Smerekówka Wielka (Glinka); 137. g. Sobański Groń (Rycerka Górna); 138. g. Sobczakowa Grapa (Laliki); 139. Soblówka; 140. g. Solański Groń (Rycerka Górna); 141. las Solisko (Soblówka); 142. g. Sołowy Wierch (Zwardoń); 143. przys. Spylowie (Rycerka Górna); 144. przys. Stańcówka (Zwardoń); 145. przys. Staronie (Nieledwia); 146. pot. Stasiowa (Rycerka Górna); 147. przys. Stawiska (Rycerka Dolna); 148. pot. Sucha Nieledwianka (Nieledwia); 149. g. Syberia (Milówka); 150. przys. Szczotka (Rycerka Górna); 151. przys. Szczytkówka (Ujsoły); 152. pol. Szkórki (Rycerka Górna); 153. przys. Szpaki (Sól); 154. przys. Śliwkówka (Soblówka); 155. pot. Śrubita (Rycerka Górna); 156. H. Śrubita (Rycerka Górna); 157. rez. Śrubita (Rycerka Górna); 158. g. Świtkowa (Soblówka); 159. przys. Tanistry (Ujsoły); 160. przys. Tarliczne (Laliki); 161. przys. Tomusie (Rajcza); 162. g. Trojaki (Jaworzynka); 163. pot. U Jurzycowej (Soblówka); 164. Ujsoły; 165. pot. Urwisko (Soblówka); 166. pot. Wielka Jaworzyna (Rycerka Górna); 167. g. Wielka Racza (Rycerka Górnba); 168. przys. Wierch Czadeczka (Bukowina); 169. g. Wiertanówka (Rycerka Dolna); 170. Wir Danielek (Mładá Hora); 171. przys. Wojniaczka (Glinka); 172. pol. Wyrobniówka (Młada Hora); 173. pot. Z Głębokiego (Rycerka Dolna); 174. g. Zabawa (Nieledwia); 175. przys. Zagajka (Sól); 176. przys. Zapasieki (Jaworzynka); 177. przys. Zawodzie (Glinka); 178. pol. Ziajówka (Rycerka Górna); 179. pot. Zimna Woda (Rycerka Górna); 180. Zwardoń; 181. przys. Żebrakówka (Glinka). Grupa Pilska (P): 182. g. Abrahamów (Żabnica); 183. pol. Alacowa (Korbielów); 184. H. Bacmańska (Złatna); 185. pol. Bartek (Pilsko); 186. g. Baścikówka (Korbielów); 
187. przys. Basiówka (Rajcza); 188. H. Bieguńska (Złatna); 189. H. Boracza (Milówka); 190. pot. Boracza (Milówka); 191. g. Boraczy Wierch (Złatna); 192. pol Boruć (Żabnica); 193. g. Bucioryska (Złatna); 194. pol. Buczynka (Żabnica Duża); 195. pot. Buczynka (Korbielów); 196. pol. Budówka (Żabnica Duża); 197. pol. Bugaj (Przyłęków); 198. przys. Bukowina (Węgierska Górka); 199. pot. Bystra (Złatna); 200. pot. Bystrzanka (Bystra); 201. H. Cebulowa (Pilsko); 202. przys. Ciaptówka (Złatna); 203. pot. Cięcinki (Cięcina); 204. H. Cudzichowa (Pilsko): 205. H. Cukiernicza Wyżnia (Żabnica); 206. przys. Czarny Groń (Korbielów); 207. g. Długi Groń (Glonka); 208. pot. Do Jodłowcowej (Sopotnia Wielka); 209. przys. Duraje (Brzuśnik); 210. H. Durajka (Juszczyna); 211. przys. Dziaski (Rajcza); 212. przys. Figury (Brzuśnik); 213. pot. Fułatów (Cisiec); 214. las Gajka (Sopotnia Mała); 215. pot. Glinna (Pilsko); 216. przeł. Glinne (Pilsko); 217. pot. Głęboki (Złatna); 218. przys. Głębokie (Złatna); 219. pol. Golcówka (Żabnica Duża); 220. H. Górowa (Korbielów); 221. przys. Graberki (Rajcza; 222. g. Grapa k. g. Abrahamów (Żabnica); 223. g. Grapa Żar (Jeleśnia); 224. g. Grojec (Sporysz); 225. g. Groń (Juszczyna); 226. pol. Gruszkowa (Zapolanka); 227. przys. Herdula (Ujsoły); 228. przys. Janikówka (Jeleśnia); 229. g. Jastrzębica (Juszczyna); 230. przys. Jastrzębie (Złatna); 231. g. Jaworzyna (Przyborów); 232. Jeleśnia, g. Jodłowcowa (Sopotnia Wielka); 233. H. Jodłowcowa (Sopotnia Wielka); 234. Juszczyna, g. Juszczynka (Juszczyna); 235. pot. Kajdasówka (Sopotnia Wielka); 236. Kamienna, g. Kępa (Trzebinia); 237. g. Kiczora k. przys. Duraje (Brzuśnik); 238. g. Kiczora k. Przyłękowa (Świnna); 239. g. Kiczora k. Ujsół (Ujsoły); 240. przys. Knoski (Żabnica Duża); 241. pol. Kobyle Młaki (Żabnica Duża); 242. przys Kolonia (Sopotnia Wielka). 243. przys. Kolonia k. Gajki (Sopotnia Mała); 244. przys. Komery (Milówka); 245. g. Kopce (Żywiec); 246. pol. Kosarzyska (Milówka); 247. pot. Kościelec (Złatna); 248. g. Kotarnica (Sopotnia Wielka); 249. g. Kotelnica (Ujsoły); 250. przys. Kotrysia Polana (Złatna); 251. pol. Koziorka (Żabnica Duża); 252. Kozi Grzbiet (Pilsko); 253. g. Krawców Wierch (Złatna); 254. pol. Krawcula (Złatna); 255. g. Krzyżowa (Sopotnia Wielka); 256. g. Kubiesówka (Glinka); 257. przys. Kupcaszki (Przyłęków); 258. H. Kupczykowa (Żabnica Duża); 259. pol. Lachowe Młaki (Sopotnia Mała); 260. pol. Latynka (Sopotnia Wielka); 261. g. Lipowska; 262. H. Lipowska; 263. pot. Loraniec (Cięcina); 264. g. Łazy (Sopotnia Wielka); 265. H. Łyśniowska (Sopotnia Wielka); 266. g. Magura (Brzuśnik); 267. g. Magurka (Złatna); 268. H. Majerkowa (Sopotnia Wielka); 269. H. Malarka (Korbielów); 270. H. Mędralowa (Korbielów); 271. pol. Między Młaki (Korbielów); 272. przys. Milówki (Milówka); 273. H. Miziowa pod g. Romanka (Sopotnia Mała); 274. H. Miziowa k. g. Pilsko (Korbielów); 275. H. Motykowa (Złatna); 276. pol. Na Boruć (Żabnica Mała); 277. Na Piętrze (Złatna); 278. przys. Na Skale (Juszczyna); 279. pot. Nickulina (Rajcza); 280. g. Okrągła (Złatna); 281. przys. Okrągła (Złatna); 282. g. Palenica (Sopotnia Wielka); 283. g. Palenica (Żabnica Mała); 284. przeł. Pawlusia (Sopotnia Wielka); 285. g. Pilsko 286. Placówka (Złatna); 287. pol. Plekońka (Złatna); 288. pol. Pogwarówka (Złatna); 289. Polany Pod Soblówką (Złatna); 290. pot. Połom (Złatna); 291. pot. Potok Jakubowski (Złatna); 292. g. Prusów (Milówka); 293. Przyłęków; 294. g. Przypór (Juszczyna); 295. przeł. Przysłopy (Korbielów); 296. H. Redykalna (Złatna); 297. g. 
Romanka (Sopotnia Wielka); 298. pot. Romanka (Żabnica Duża); 299. g. Rysianka (Złatna); 300. H. Rysianka (Złatna); 301. rez. Rysianka (Sopotnia Wielka); 302. pot. Sikorczany (Żabnica Duża); 303. g. Skałka (Sopotnia Wielka); 304. przys. Skałka (Żabnica Duża); 305. H. Skórzacka (Złatna); 306. H. Słowikowa (Korbielów); 307. przys. Solany (Cięcina); 308. pot. Solarzówka (Milówka); 309. g. Solisko (Korbielów); 310. Sopotnia Mała; 311. pot. Sopotnia Mała (Sopotnia Mała); 312. Sopotnia Wielka; 313. pot. Sopotnia Wielka (Sopotnia Wielka); 314. Sporysz, pot. Stara Piła (Złatna); 315. pot. Straceniec (Złatna); 316. pot. Studziański (Żabnica Duża); 317. g. Sucha Góra (Milówka); 318. przys. Sucha Góra (Milówka); 319. pot. Suchy (Żabnica Duża); 320. przys. Sułki (Złatna); 321. pot. Suseński (Jeleśnia); 322. pot. Syndzielny (Żabnica Duża); 323. H. Szczawina (Korbielów); 324. g. Szczawinka (Sopotnia Wielka); 325. pol. Szczyrbowe Młaki (Milówka); 326. Szeroki Kamieniec (Złatna); 327. przys. Sznurki (Żabnica Duża); 328. pot. Śmierdzący Potok (Złatna); 329. las Tejch (Sopotnia Mała); 330. przys Tokarnia (Żabnica Duża); 331. Trzebinia; 332. g. Trzy Kopce (Sopotnia Wielka); 333. Turniczka (Pilsko); 334. przys. U Kotrysiej Polany (Złatna); 335. pol. Uszczawne (Sopotnia Wielka); 336. dol. W Ciemnym (Sopotnia Wielka); 337. dol. W Kotarnicy (Sopotnia Wielka); 338. Węgierska Górka; 339. H. Wieprzska (Sopotnia Mała); 340. g. Wilczy Groń (Złatna); 341. pot. Wojtasi (Żabnica Duża); 342. g. Wolentarski Groń (Świnna); 343. pot. Z Gawłowskiego (Złatna); 344. pot. Z Wideł (Złatna); 345. pol. Za Jurkową (Korbielów); 346. przys. Za Kopcem (Milówka); 347. przys. Zagroń (Złatna); 348. pot. Zająców Potok (Złatna); 349. przys. Zapolanka (Złatna); 350. Złatna, Złotnice (Złatna); 351. pot. Żabnicka Rzeka (Żabnica Duża); 352. pol. Żor (Przyłęków).

Masyw Babiej Góry (BG): 353. Akademicka Perć; 354. przeł. Brona; 355. H. Czarna; 356. g. Cyl; 357. g. Diablak, g. Główniak; 358. pot. Jałowiec; 359. g. Kępa; 360. pot. Kiczorka; 361. Kościółki; 362. H. Kralowa; 363. g. Mała Babia; 364. przys. Markowa; 365. Markowe Szczawiny; 366. pot. Marków Potok; 367. ruiny schroniska; 368. g. Sokolica; 369. pot. Suchy Potok (Rybny Potok).

Pasmo Jałowca (J): 370. przys. Adamy (Lachowice; 371. g. Babiarzówka (Stryszawa); 372. przys. Barankowa (Zawoja); 373. przys. Baranówka (Zawoja); 374. przys. Bartoszki (Stryszawa); 375. przys. Beskidek (Koszarawa); 376. g. Biały Wierch (Koszarawa); 377. przys. Boguniówka (Stryszawa); 378. pot. Bystra (Koszarawa); 379. przys. Chrząszcze (Niedźwiedź); 380. przys. Chudziakówka (Sucha); 381. przys. Cicha (Koszarawa); 382. pot. Czerna (Stryszawa); 383. g. Czerniańska (Stryszawa); 384. las Czerniawa (Koszarawa); 385. g. Czerniawa Sucha (Koszarawa); 386. pot. Dejówka (Skawica); 387. g. Drwalowa (Zasepnica); 388. przys. Drwalówka (Sucha); 389. przys. Figury (Zawoja); 390. g. Gawronowa (Stryszawa); 391. pot. Głucha (Przyborów); 392. przys. Głuchaczki (Przyborów); 393. przys. Głuszki (Stryszawa); 394. pot. Gołyńka (Zawoja); 395. g. Grzechynia (Grzechynia); 396. Grzechynia; 397. pot. Grzechynka (Grzechynia); 398. pot. Hucisko (Stryszawa); 399. przys. Hyrby (Niedźwiedź); 400. g. Jałowiec k. g. Mędralowej (Koszarawa); 401. g. Jałowiec (Koszarawa); 402. przys. Jałowiec (Koszarawa); 403. przeł. Jałowiecka (Zawoja); 404. przys. Janiczki (Niedźwiedź); 405. przys. Janiki (Zasepnica); 406. g. Janoszka (Stryszawa); 407. H. Janoszkowa (Koszarawa); 408. przys. Jarliki (Stryszawa); 409. g. 
Jaworzyna (Przyborów); 410. przys. Kalinka Dolna (Zawoja); 411. pot. Kalinka (Zawoja); 412. g. Kamienna (Zasepnica); 413. H. Kamińskiego (Zawoja); 414. przys. Kępy (Stryszawa); 415. g. Kiczora (Zawoja); 416. przys. Kiecka (Zawoja); 417. przys. Kijakowa (Zawoja); 418. g. Kiklówka (Zawoja); 419. przeł. Klekociny (Przyborów); 420. przys. Kobiele (Skawica); 421. przys. Kolędówka (Zawoja); 422. pot. Kolędowy Potok (Zawoja); 423. przys. Kowaliczki (Stryszawa); 424. przys. Kowalówka (Grzechynia); 425. H. Kubalkowa (Koszarawa); 426. przys. Kubasy (Zasepnica); 427. przys. Kubiasiaki (Zasepnica); 428. przys. Kudzie (Zawoja); 429. g. Kwakowa (Stryszawa; 430. g. Lachów Groń nad Bystrą (Koszarawa); 431. g. Lachów Groń nad Skawicą (Skawica); 432. przys. Łabędzie (Zawoja); 433. g. Magurka (Zasepnica); 434. pol. Magurka (Zawoja); 435. pot. Magurka (Zawoja); 436. przys. Matusy (Stryszawa); 437. g. Mędralowa (Koszarawa); 438. przys. Nowy Świat (Sucha); 439. przys. Opaczne (Zawoja); 440. pot. Opaczny (Zawoja); 441. g. Ostra Górka (Grzechynia); 442. przys. Pasierbiaki (Zasepnica); 443. przys. Pindelówka (Koszarawa); 444. przys. Podjałowiec (Koszarawa); 445. przys. Podksięże (Sucha); 446. przys. Polanki Pierglesowe (Zawoja); 447. przys. Porębscy (Niedźwiedź); 448. g. Przyborówka (Przyborów); 449. przys. Pytel (Zasepnica); 450. przys. Roztoki (Sryszawa); 451. przys. Semikówka (Zasepnica); 452. przys. Siurówka (Koszarawa); 453. przys. Siwcówka (Stryszawa); 454. pol. Skalaniec (Koszarawa); 455. g. Skupniówka (Grzechynia); 456. przys. Skupniówka (Grzechynia); 457. przys. Smeraki (Zawoja); 458. przys. Spikówka (Zawoja); 459. przys. Spyrki (Zasepnica); 460. pot. Stracony Potok (Stryszawa); 461. g. Sumerówka (Sucha); 462. g. Surmiaków Groń (Zawoja); 463. g. Surzynówka (Stryszawa); 464. przys. Szarleje (Stryszawa); 465. przys. Szczórkówka (Zawoja); 466. g. Szelust (Korbielów); 467. g. Szczyrk (Przyborów); 468. H. Trzebuniaków (Zawoja); 469. g. Urwisko (Skawica Górna); 470. pol. W Gawronówce (Zasepnica); 471. przys. Wełcza (Zawoja); 472. g. Wełczon (Zawoja); 473. g. Westka (Korbielów); 474. pot. Wilkówka (Grzechynia); 475. g. Witkówka (Grzechynia); 476. przys. Wygoda (Stryszawa); 477. przys. Za Grapą (Koszarawa); 478. pot. Zasepnica (Zasepnica); 479. przys. Zimna Woda (Koszarawa); 480. g. Zimna (Korbielów); 481. przys. Złabne (Koszarawa).

\section{Wykaz gatunków}

Wykaz zawiera 543 gatunki porostów ułożone alfabetycznie i opisane według schematu: nazwa gatunku, synonim, siedlisko, liczba stanowisk i ich wykaz wraz $\mathrm{z}$ wysokością nad poziom morza $[1130=1130 \mathrm{~m}$ n.p.m.]; w nawiasach podano nazwę gminy, miejscowości lub góry, dla ułatwienia lokalizacji niektórych stanowisk.

Skróty (Abbreviations): dol. - dolina (valley); g. - góra (mountain); E - wschodni (eastern); H. - hala (pasture alpine); k. koło (near); kos. - piętro kosodrzewiny (subalpine belt); m. - między (between); N - północny (northern); pg. - pogórze (submontane belt); pol. - polana (glade); pot. - potok (stream); przeł. - przełęcz (pass); przys. - przysiółek (thorp); rg. d. - regiel dolny (lower montane belt); rg. g. - regiel górny (upper montane belt); rez. - rezerwat (nature reserve); S - południowy (southern); stan. stanowiska (localities). 


\section{Absconditella lignicola Vlězda \& Pišut - Czołowe powierzchnie butwiejących}

pniaków świerkowych; rg. d.

1 stan. BG: pot. Kiczorka 1130.

Acarospora badiofusca (Nyl.) Th. Fr. - Piaskowce (skały, ruiny spalonego schroniska); miejsca suche i widne; kos.

2 stan. BG: Diablak 1725; S stoki Diablaka 1600.

A. fuscata (Schrad.) Th. Fr. - Bezwapienne piaskowce (skały, stosy kamieni, luźne murki, słupki kamienne, głazy nad brzegami potoków i rzek); miejsca suche i widne; pg., rg. d., rg. g., kos.

203 stan. WR: Ochodziła 760; g. Kiczorka 685, 750; g. Ochodzita 820; g. Zabawa 760, 800; g. Popręcina 775; Młaki 700; Do Staruni 770; g. Podgórka 785; g. Kiczora 680, 700; Staronie 760; pol. Butorza 740; Głębokie 660; g. Groniczek 830; g. Rachowiec 850, 910; g. Klimasy 710; pot. Z Głębokiego 550; g. Hutyrów 670, 700; g. Skalanka 800; dol. Ujsoły 520; g. Beskid Wrzesz 860; g. Solański Groń 690; g. Burów Groń 690; g. Łysica 650, 680; g. Kokocz 720; Stawiska 770; g. Oźna 760, 880, 930; dol. Danielki 700; Szczytkówka 870, 875; g. Jaworzyna 900, 945, 1020; g. Obłaz 830; g. Praszywka Duża 970, 980, 1030; pol. Gardasówka 830; pol. Wyrobniówka 900, 925; g. Muńczoł 1120, 1165; Magura 820, 850; pol. Bułkowa 760; Przysłop Połucki 870; g. Kiczorka 985; Skomisko 680; pol. Cerla 1025; pol. Janeczkowe Rycerki 715; pol. Raztoki 750; pol. Fod Raczą 715; H. Przysłop 940; pol. Majów 825; pot. Dzięboki 770; g. Będoszka Wielka 1100, 1130; pol. Kołyska 1010; g. Rycerzowa 1170; H. Mała Racza 1070, 1135; g. Wielka Racza 1235; H. Śrubita 1000; g. Bugaj 1050; g. Jaworzyna k. Bugaja 1120; g. Abramów 1080. P: Sporysz 420; g. Jastrzębica 750; pot. Suseński 480; pot. Loraniec 480; Duraje 610, 730; g. Przypór 855; m. g. Kiczora i g. Magurka 840; Na Skale 860; H. Durajka 835; g. Abrahamów 700, 760; g. Magura 850, 878; g. Juszczynka 880; g. Grapa 600; Sopotnia Wielka 735; g. Lazy 995; g. Palenica 630, 665; Tokarnia 780; g. Kotarnica 1000, 1015, 1160; pol. Boruć 795, 840; H. Miziowa na Romance 1100; H. Majerkowa 1075; g. Prusów 965, 1000, 1005; H. Malarka 1030; pot. Suchy 630; pol. Na Boruć 895; H. Wieprzska 1060; g. Skałka 1130; Kolonia 750; pol. Buczynka 880; Milówki 920; g. Baścikówka 850; H. Pawlusia 1170; H. Szczawina 1115; m. Sznurki i Dadoki 865; leśniczówka Glinne 750; H. Rysianka 1240, 1300; g. Pilsko 1385; H. Cudzichowa 1250, 1260; pol. Szczyrówe Młaki 885; Sucha Góra 750, 920, 960, 1000, 1020; g. Solisko 1180; H. Skórzacka 1125; H. Bieguńska 1160, 1190; H. Lipowska 1140, 1150, 1200, 1250; H. Redykalna 1060, 1080; pol. Gruszkowa 1000; H. Motykowa 1060; przys. Dziaski 735; g. Bucioryska 760; pot. Z Gawłowskiego 645; g. Okrągła 920, 930, 940; przys. Głębokie 580; pot. Głęboki 630; g. Kubiesówka 790, 850; pol. Długi Groń 880; pol. Pogwarówka 925; pol. Plekońka 960; pol. Krawcula 1035; g. Kotelnica 760. BG: H. Czarna 1080; H. Kralowa 1395; Cyl 1515; Diablak 1660. J: Sumerowa Góra 565; g. Czerniańska 500; g. Drwalówka 690; Ostra Górka 610; Janiki 500, 770; Kubiasiaki 690; pot. Grzechynka 450; g. Grzechynia 550; g. Skupniówka 600; g. Kwakowa 670; g. Magurka 870; g. Surzynówka 810; g. Janoszka 720; g. Kiczora 900; dol. Kalinki 540; g. Lachów Groń nad Skawicą 600; pot. Gołyńka 520; g. Witkówka 650; Opaczne 900; Figury 810; Kolędówka 800; g. Babiarzówka 860; g. Surmiaków Groń 730; Baranówka 700; pot. Kolędowy Potok 650; H. Trzebuniaków 1050; pol. Skalaniec 900; g. Biały Wierch 1040; g. Kiklówka 475; g. Wetczon 800, 840; g. Lachów Groń nad Bystrą 1045; Beskidek 1010; Kijakowa 810; pol. Magurka 880; pot. Bystra 700; g. Mały Jałowiec 995; H. Kamińskiego 1118; g. Mędralowa 1170; pot. Głucha 580; Pindelówka 1050; Głuchaczki 580; g. Przyborówka 850; m. g. Jaworzyna i g. Szelust 900.

rg. d.

A. glaucocarpa (Ach.) Koerb. - Wapniste piaskowce; miejsca cieniste i suche;

3 stan. WR: pot. Urwisko 700. P: Milówki 700; H. Durajka 835.

A. cf. insolata H. Magn. - Bezwapienne piaskowce (skałki, głazy nad brzegami potoków i rzek, stosy kamieni itp.); miejsca suche i widne; pg., rg. d., rg. g. 7 stan. P: pot. Bystra 510; pol. Szczyrbowe Młaki 890; g. Sucha Góra 1020; H. Malarka 1050; g. Skałka 1195; g. Rysianka 1310. J: H. Kubalkowa 1080.

A. oligospora (Nyl.) Arnold - Luźne kamyki piaskowcowe po halach; rg. d. 1 stan. J: g. Mędralowa 1170. 
A. smaragdula (Wahlenb. in Ach.) Massal. - Kamyki piaskowcowe leżące luzem; kos.

1 stan. BG: Sokolica 1370.

A. umbilicata Bagl. - Bezwapienne, rzadziej słabo wapniste piaskowce (skałki, głazy); miejsca suche i widne ; rg. d.

2 stan. WR: g. Jaworzyna 1000. P: g. Sucha Góra 960.

A. veronensis Massal. - Bezwapienne piaskowce (kamieńce nad rzekami i potokami, stosy kamieni, osuwiska); miejsca suche i widne; pg., rg. d., kos. 13 stan. WR: Ujsoły 520; pot. Z Głębokiego 550; g. Hutyrów 650; pot. Danielka 650; Szczytkówka 875. P: g. Baścikówka 810; pol. Gruszkowa 1000; pot. Boracza 1025; H. Redykalna 1060; H. Wieprzska 1060; g. Pilsko 1500. J: m. Grzechynią a Skupniówką 470; g. Mędralowa 1170.

Acrocordia gemmata (Ach.) Massal. $[=$ A. alba (Schrad.) B. de Lesd.) Gładka kora drzew liściastych; pg., rg. d.

3 stan. WR: leśniczówka Janikówka 415; g. Bednarów Beskid 950. P: pot. Stara Piła 900.

Alectoria nigricans (Ach.) Nyl. - Bezwęglanowa gleba wśród skał piaskowcowych; kos.

2 stan. BG: Diablak 1700; m. Kościółkami a Diablakiem 1625.

A. ochroleuca (Hoffm.) Massal. - Bezwęglanowa gleba wśród piaskowców; kos. 11 stan. BG: Kępa 1520, 1530; Główniak 1570; m. Kościółkami a Diablakiem 1625; pod Diablakiem 1580, 1660, 1665, 1680, 1690; Diablak 1700, 1710.

A. sarmentosa (Ach.) Ach. - Gałęzie starych świerków w borach górnoreglowych; rg. g.

6 stan. P: las pod H. Mędralową 1280; g. Rysianka 1300, 1320; g. Romanka 1340. BG: pod Akademicką Percią 1235 ;.m. Markowymi Szczawinami a przeł. Brona 1350.

Amandinea punctata (Hoffm.) Coppins \& Scheidegger [= Buellia punctata (Hoffm.) Massal., B. stigmatea (Schaer.) Koerb.] - Kora drzew liściastych oraz bezwapienne piaskowce (najczęściej drobne kamienie); miejsca widne i suche; pg., rg. d. 48 stan. WR: pot. Sucha Nieledwianka 485; Kasperki 670; pot. Czadeczka 500, 545; pot. Krążelka 510, 520; nad przys. Chromiaki 650; przys. Karchówka 565; m. g. Kiczora a g. Popręcina 685; Szpaki 570; przys. Pławuchowa 520; g. Oźna 950; Ujsoły 520, 530; pot. Rycerka 580; Spylowie 550; pot. Radecki 670; Szczytkówka 875; Słonkówka 750; pol. Bułkowa 760; Smereków Wielki 750; leśniczowka Pod Raczą 715; g. Rycerzowa 1150. P: Jeleśnia 415; Trzebinia 425; g. Grapa Żar 430; pot. Bystrzanka 510, 585; Solany 445; Żabnicka Rzeka 590; pot. Do Jodłowcowej 850; E stok g. Kotarnica 1000; Kamienna 650, pot. Nickulina 520; Złatna 610; pol. Kotrysia Polana 720. J: Wygoda 420; dol. Zasepnicy 440, 460; Semikówka 550; pot. Surmiaków 600; Złabne 680; Hyrby 680; H. Trzebuniaków 1030.

Anaptychia ciliaris (L.) Koerb. - Kora drzew liściastych, przeważnie przydrożnych lub samotnie rosnących, np. jesionów; rg. d.

1 stan. WR: Szczotka 900.

Arthonia lapidicola (Tayl.) Branth \& Rostr. - Wapniste skałki i głazy zwykle nad potokami górskimi; miejsca widne lub nieco cieniste; pg., rg. d.

4 stan. WR: Karchówka 565. P: pot. Sopotnia Wielka 870. J: dol. Grzechynki 575; m. Grzechynią a Skupniówką 470 .

A. leucopellea (Ach.) Almqu. - Kora starych drzew iglastych; rg. d., rg. g. 19 stan. WR: rez. Śrubita 810; g. Bednarów Beskid 900; rez, Oszus 1000. P: rez. Rysianka 900, 1050, 1100; pot. Stara Piła 900; pot. Zająców Potok 940; pol. Bartek 1160; pol. Między Młaki 1200; poniżej H. Mędralowej 1250; g. Lipowska 1260; pot. Glinna 1260; g. Romanka 1350. BG: las poniżej H. Czarnej 1040; poniżej Sokolicy 1090, 1230; poniżej Akademickiej Perci 1235; m. Markowymi Szczawinami a przeł. Brona 1255 . 
A. mediella Nyl. - Kora starych drzew iglastych i liściastych w naturalnych lasach; rg. d.

3 stan. WR: pot. Urwisko 760. P: pot. Zająców Potok 1000; g. Pilsko (H. Miziowa) 1220.

A. punctiformis Ach. - Kora młodych drzew liściastych o gładkiej powierzchni (jawory); rg. d.

1 stan. P: pol. Kotrysia Polana 720.

A. radiata (Pers.) Ach. - Kora drzew liściastych o gładkiej powierzchni (olchy, buki, jarzębiny, jawory), rosnących głównie w naturalnych lasach; pg., rg. d.

31 stan. WR: g. Sobczakowa Grapa 715; Podścigłów 700; pol. Bułkowa 760; Skomisko 680; pot. Przegibek 760; g. Majcherowa 950; pot. Śrubita 975; las Orzeł 1030; pol. Skrzadnita 1105. P: leśniczówka Straceniec 775; Na Piętrze 835; Polany Pod Soblówką 900; H. Malarka 1000; pot. Zająców Potok 1000; H. Jodłowcowa 1100; poniżej H. Bacmańskiej 1125; las nad H. Wieprzską (Romanka) 1150, 1160. BG: las poniżej H. Czarnej 1160; las poniżej Akdemickiej Perci 1340. J: H. Trzebuniaków 1030; H. Kamińskiego 1080; pol. Magurka 825; g. Kiczora 880; dol. Głucha 600; Podjałowiec 930; g. Czerniańska 580; Dolinka 580; Zimna Woda 680; dol. Zasepnicy 460; pot. Stracony Potok 600; dol. Czernej 580.

pg.

A. spadicea Leight. [ = A. lurida Ach.] - Kora starych drzew iglastych, np. jodły;

1 stan. J: blisko Siwcówki 570.

A. vinosa Leight. $[=A$. lurida auct. $]$ - Kora starych drzew liściastych, rosnących w naturalnych lasach oraz butwiejące pniaki; miejsca cieniste i wilgotne; rg. d.

11 stan. WR: pot. Plaskurówka 750; las Orzeł 965; g. Bednarów Beskid 940; rez. Oszus 950; g. Bugaj 1050. P: dol. W Kotarnicy 820; Polany Pod Soblówką 900; rez. Rysianka 1025, 1140; las ponad H. Wieprzską (Romanka) 1150; H. Jodłowcowa 1200.

Arthopyrenia grisea (Schleich. ex Schaer.) Koerb. - Kora drzew liściastych (buki, przydrożne jarzębiny); rg. d.

3 stan. WR: pot. Rycerka 630; g. Upłaz 1020; las Orzeł 1030.

A. punctiformis (Pers.) Massal. [= A. persoonii Massal.] - Gładka kora drzew liściastych; pg., rg. d.

5 stan. P: Złatna (u wylotu Potoku Jakubowskiego) 600; leśniczówka Straceniec 775. J: Boguniówka 525; g. Sumerówka 565 ; g. Kiczora 880.

Arthrorhaphis alpina (Schaer.) R. Sant. in Hawksw., James \& Coppins [= Bacidia alpina (Schaer.) Vain.] - Gatunek podany z Babiej Góry (SuZA 1951) pod nazwą $A$. flavovirescens var. alpina.

A. citrinella (Ach.) Poelt [ = Bacidia citrinella (Ach.) Branth. \& Rostr.] - Gliniasta gleba nad ścieżkami i drogami leśnymi, w szczelinach skał bezwapiennych; rg. d, rg. g., kos.

17 stan. WR: Lastoczka 675; Raztoki 700; pot. Przegibek 750; Magurka 850. P: pot. Potok Jakubowski 630; pot. Glinna 1165; dol. W Ciemnym 1170; g. Pilsko 1445. BG: Kościółki 1500, 1510, 1580; Akademicka Perć 1525, 1570; Diablak 1725. J: pot. Głucha 680; przeł. Klekociny 920; H. Kamińskiego 1118.

Arthothelium ruanum (Massal.) Koerb. [ = A. ruanideum (Nyl.) Arnold] - Kora młodszych drzew liściastych (głównie olch szarych) rosnących nad potokami i rzekami, przeważnie stopy pni; pg., rg. d.

5 stan. WR: Soblówka 710. J: pot. Hucisko 500; Kępy 500; Dolinka 580; pot. Stracony Potok 600.

Aspicilia aquatica Koerb. [= Lecanora aquatica (Koerb.) Hepp] - Bezwapienne głazy piaskowcowe stale zalewane wodą w potokach wysokogórskich; kos.

1 stan. P: g. Pilsko (źródła pot. Glinna) 1350. 
A. caesiocinerea (Nyl. ex Malbr.) Arnold [= Lecanora caesiocinerea Nyl. ex Malbr.] - Bezwapienne piaskowce (stosy kamieni, luźne murki, gołoborza, głazy po halach i polanach); miejsca suche i widne ; pg., rg. d., rg. g., kos.

25 stan. WR: g. Rachowiec 850; pol. Raztoki 750; Przysłop Połucki 870; g. Jaworzyna 1000; H. Śrubita 1000; g. Bugaj 1050; g. Abrahamów 1070; g. Będoszka Wielka 1100; g. Muńczoł 1120, 1165. P: pot. Bystra 510; pol. Krawcula 1035; H. Redykalna 1085; H. Lipowska 1150; H. Bieguńska 1160; przel. Pawlusia 1170; H. Lipowska 1200, 1250. BG: Kościółki 1510; ruiny schroniska pod Diablakiem 1600; ponad H. Kralową 1395. J: g. Skupniówka 600; m. Chrząszczami i Toporami 700; Jałowiec 750; Opaczne 960.

A. calcarea (L.) Mudd [= Lecanora calcarea (L.) Sommerf.] - Silnie wapniste piaskowce i zlepieńce; suche i widne miejsca; pg.

6 stan. WR: Rycerka 515; Rycerka Dolna (g. Łysica) 550. P: Sporysz 430. J: dol. Grzechynki 450; m. Gzechynią a Skupniówką 450; dol. Kalinki 540 .

A. cinerea (L.) Koerb. [= Lecanora cinerea (L.) Sommerf. $]$ - Bezwapienne piaskowce, zwykle suche i widne skały; rg.d., rg. g.

4 stan. P: g. Kotelnica 700; g. Skałka 1195. J: m. Chrząszczami a Toporami 700; g. Mędralowa 1170.

A. contorta (Hoffm.) Krempelh. [ = Lecanora contorta (Hoffm.) Stnr.] - Wapienie i wapniste piaskowce, rzadziej na betonie; miejsca suche i widne; pg., rg. d. 7 stan. WR: Rycerka 515; Zwardoń 650; g. Łysica 550. P: Sporysz 430. J: dol. Gołyńki 450; dol. Grzechynki 520; pot. Surmiaków 550 .

\section{A. c. subsp. hoffmaniana Ekman \& Froberg in Froberg [= A. hoffmanii auct.]}

- Wapienie lub wapniste piaskowce i zlepieńce; miejsca suche i widne; pg.

3 stan. WR: Rycerka 515. P: Sporysz 390, 420.

A. insolata (H. Magn.) Hav. [= Lecanora insolata H. Magn.] - Bezwapienne piaskowce; miejsca suche i widne; pg., rg. d., rg. g.

4 stan. P: stok nad Durajami 610; Polany Pod Soblówką 900; H. Bieguńska 1200. J: Janiczki 540.

A. laevata (Ach.) Arnold [= Lecanora laevata (Ach.) Nyl.] - Bezwapienne piaskowce (stosy kamieni, luźne murki, głazy po halach i polanach oraz nad potokami, gołoborza); miejsca suche i widne; rg. d., rg. g.

89 stan. WR: g. Zabawa 760, 800; g. Kiczorka 725; g. Rachowiec 850; g. Skalanka 785; Szczotka 870; g.Hutyrów 700; Rycerka Dolna 550; Oźna 760, 870, 930; pol. Szczytkówka 870, 875; m. g. Jaworzyna a g. Magura 945; g. Jaworzyna 900; g. Praszywka Duża 1030; H. Muńczoł 1120; pol. Wyrobniówka 900; Magura 850; Przysłop Połucki 870; pol. Cerla 1025; pol. Joneczkowe Rycerki 715; pol. Raztoki 750; pol. Majów 825; pot. Dzięboki 770; g. Będoszka Wielka 1100; pol. Kołyska 1010; H. Mała Racza 1070, 1135; g. Wielka Racza 1235; pol. Głowa 940; H. Śrubita 1000; g. Abramów 1080; g. Jaworzyna koło Bugaja 1150. P: g. Jastrzębica 750; H. Miziowa na Romance 1100; poniżej H. Majerkowej 1075; pot. Do Jodłowcowej 725 ; pol. Boruć 840; pol. Na Boruć 895; g. Malarka 1050; Sopotnia Wielka 735; E stok g. Kotarnica 1010; przys. Tokarnia 780, 850; H. Wieprzska 1060; dol. W Ciemnym 950; pol. Buczynka 880; g. Prusów 1000; powyżej Milówki 920; pol. Alacowa 925; g. Baścikówka 880; g. Skałka 1195; Milówki 785; m. Sznurkami a Dadokami 865; g. Romanka 1180; leśniczówka Glinne 750; H. Rysianka 1240, 1310; H. Cudzichowa 1260; m. H. Miziową a H. Jodłowcową 1250; H. Skórzacka 1125; H. Bieguńska 1160, 1190, 1200; H. Lipowska 1140, 1250; g. Trzy Kopce 1215; pol. Sucha Góra 930, 1000; powyżej Graberek 875, 900; pol. Gruszkowa 1000; H. Motykowa 1050, 1060; H. Redykalna 1080; m. Zająców Potokiem a Śmierdzącym Potokiem 1000; Okrągłe 930; pol. Długi Groń 880; pol. Plekońka 960; pol. Krawcula 1035; Polany Pod Soblówką 900. BG: H. Czarna 1080; ruiny schroniska pod Diablakiem 1600. J: g. Skupniówka 600; g. Ostra Górka 610; Kolędowy Potok 650; Drwalówka 690; Kubiasiaki 690; Figury 700; g. Janoszka 720; dol. Głucha 730; Kolędówka 800; g. Wełczon 850; pol. Magurka 880; g. Kiczora 900; Opaczne 950; H. Trzebuniaków 1050; H. Kamińskiego 1100.

A. moenium (Vain.) Thor \& Timdal $[=$ A. excavata Thor \& Timdal $]-$ Betonowe słupki; miejsca widne i suche; pg.

1 stan. J: Grzechynia 380. 
A. simoensis Räs. [= Lecanora simoensis (Räs.) A. Zahlbr.] - Bezwapienne piaskowce (stosy kamieni, gołoborza i piargi, głazy po halach i polanach), najczęściej w stanie płonnym; miejsca suche i widne; rg. d., rg. g., kos.

46 stan. WR: g. Zabawa 800; Pietraszyna 840; g. Rachowiec 850; Rycerka Dolna 515; g. Łysica 560, 640; g. Hutyrów 670; g. Klimasy 710; pol. Joneczkowe Rycerki 715; g. Oźna 760; pol. Bułkowa 760; pol. Gardasówka 830; Obłaz 830; Magura 850; Szczotka 870; pol. Wyrobniówka 900; H. Przysłop 940; g. Jaworzyna 1020; H. Śrubita 1000; g. Bugaj 1050; H. Mała Racza 1070; g. Będoszka Wielka (z apotecjami) 1100; g. Rycerzowa 1170. P: leśniczówka Glinne 750; g. Abrahamów 780; g. Okrągła 850; g. Baścikówka 850; g. Magura 870; g. Długi Groń 880; Tokarnia 890; pol. Na Boruć 890; Milówki 900; g. Prusów (z apotecjami) 1005; pol. Krawcula 1035; Sucha Góra (z apotecjami) 1040; g. Malarka 1050; H. Jodłowcowa 1200. BG: pot. Suchy Potok 1365; Kępa 1520; poniżej Diablaka 1600; Diablak 1700.

Bacidia bagliettoana (Massal \& De Not. in Massal.) Jatta [ = B. muscorum (Sw.) Mudd] - Obumierające mchy naziemne na glebie wapnistej: pg. 1 stan. P: Sporysz 420.

B. beckhausii Koerb. - Kora drzew liściastych, głównie buków, rosnących w naturalnych lasach; rg. d.

1 stan. WR: g. Rycerzowa 1105.

B. globulosa (Flk.) Hafellner \& V. Wirth in V. Wirth [ = Catillaria globulosa $($ Flk.) Th. Fr.] - Kora drzew liściastych, zwykle w naturalnych lasach; rg. d.

12 stan. WR: g. Będoszka Wielka 1000. P: pol. Bura Polana 665; dol. Do Jodłowcowej 835; H. Lipowska 1100; H. Bacmańska 1125; rez. Rysianka 1140; H. Wieprzska 1150. J: dol. Bystrej 600; Beskidek 1010; H. Trzebuniaków 1030; H. Kamińskiego 1050; g. Mędralowa 1150.

B. incompta (Borr. ex Hook.) Anzi - Nagie stare drewno we wnętrzu wypróchniałego starego jawora, normalnie rośnie na korze drzew; rg. d.

1 stan. P: las poniżej H. Lipowskiej 1100.

B. naegelii (Hepp) A. Zahlbr. - Kora drzew liściastych (wierzby), rzadziej iglastych; pg., rg. d.

2 stan. WR: pot. Krążelka 520; g. Bednarów Beskid 1000.

B. rubella (Hoffm.) Massal. [=B. luteola '(Ach,)' Mudd] - Kora drzew liściastych, zwłaszcza na omszałych pniach w naturalnych lasach; miejsca widne; rg. d.

6 stan. WR: pol. Skrzadnita 1105. P: las poniżej H. Bieguńskiej 1150; las ponad H. Wieprzską 1150; H. Rysianka 1200. J: Pytel 600; H. Kamińskiego 1050, 1100.

B. subincompta (Nyl.) Arnold - Kora drzew liściastych (buki); rg. d. 2 stan. WR: g. Rycerzowa 1120. J: Za Grapą 775.

Bacidina inundata (Fr.) Vězda [ = Bacidia inundata (Fr.) Koerb.] - Bezwapienne głazy i kamienie piaskowcowe okresowo zwilżane wodą na dnach potoków górskich; pg., rg. d. rg. g.

57 stan. WR: pot. Czadeczka 500; k. miejscowości Laliki Wielkie 650; pot. Racza 835; pot. Stasiowa 700; pol. Pawliki 755; pot. Wielka Jaworzyna 860; pot. Plaskurówka 735; Soblówka 670; pot. Danielka 755; Szczotka 880; Rycerki 620. P: Sopotnia Wielka 650, 840; dol. W Kotarnicy 830, 850; dol. Do Jodłowcowej 850; pot. Kajdasówka 860; pot. Glinna 1150, 1305; pol. Kotrysia Polana 735; Na Piętrze 800; pot. Śmierdzący Potok 750; pot. Zająców Potok 820, 975; pot. Z Gawłowskiego 760; pot. Studziański 635; pot. Suchy 630; pot. Sikorczany 735; pot. Bystra 530, 640; pot. Fułatów 460; H. Wieprzska 1040; Korbielów 590. BG: pot. Kiczorka 1130; H. Kralowa 1120. J: S stoki g. Jałowiec 1000; Kolędowy Potok 650; m. Wełczą a Kudziami 575; pot. Magurka 750; poniżej g. Mędralowa 850; pot. Bystra 600, 680, 700; m. g. Jałowiec a g. Lachów Groń 800; dol. Zasepnicy 440, 550; pot. Grzechynka 450, 575; pot. Czerna 500; Janiczki 540; poniżej Podjałowca 850; przel. Klekociny 890, 900. 
B. phacodes (Koerb.) Vězda [= Bacidia phacodes Koerb.] - Stare murszejące drewno, często czoła pniaków, rzadziej kora żywych drzew liściastych; pg., rg. d., rg. g.

53 stan. WR: Kępki 570; Zagajka 625; g. Trojaki 660; Zwardoń 670; g. Kiczorka 725, 780; g. Zabawa 740; Do Staroni 760; Orawcowa 775; leśniczówka Janikówka 415; pot. Stasiowa 650; pot. Butorzy 680; pot. Urwisko 700; pot. D́anielka 700; pol. Raztoki 700; pol. Śliwcówka 730; pot. Plaskurówka 735; g. Hutyrów 740; opodal Szczytkówki 750; g. Beskid Wrzeszcz 780; Szczotka 870; g. Plaskierówka 1000; g. Upłaz 1030, 1065; H. Muńczoł 1125; g. Rycerzowa 1205. P: pot. Bystrzanka 470; Komery 575; pot. Wojtasi 640; pot. Z Gawłowskiego 640; k. Płonego 660; Herdula 695; dol. poniżej Uszczawnego 800; pot. Zająców Potok 800; przel. Glinne 820; Zapolanka 845; g. Okrągła 850, 950; Za Jurkową 880; Złotnice 925; g. Wilczy Groń 940; H. Motykowa 1050; H. Wieprzska 1060; g..Magurka blisko g. Trzy Kopce 1100; H. Rysianka 1100; g. Lipowska 1320; g. Pilsko 1320. BG: pot. Marków 740. J: przeł. Klekociny 930; Pindelówka 1050; Siurówka 690; Roztoki 650; Siwcówka 600; przeł. Jałowiecka 1017; g. Magurka 870; Drwalówka 690; pot. Grzechynka 450, 550; g. Grzechynia 550; m. Grzechynią a Skupniówką 475; g. Skupniówka 650; g. Janoszka 700; pot. Czerna 580 .

Baeomyces rufus (Huds.) Rebent. - Bezwapienne piaskowce (głazy i kamienie, rzadziej większe skałki) w cienistych lasach, dolinach, nad potokami lub na nagiej gliniastej glebie, rzadko na butwiejących kłodach; pg., rg. d., rg. g.

109 stan. WR: pot. Czadeczka 530; g. Skalanka 785; dol. Radeckiego 700; dol. Danielka 725; przełęcz m. g. Magura a g. Jaworzyna 945; ponad pol. Juraszkową 885; pol. Gardasówka 800; Podścigłów 700; Magura 850; pot. Stasiowa 700; pol. Bułkowa 785; g. Kotarz 1080; Śliwkówka 730; g. Wiertalówka 1040; pol. Janeczkowe Rycerki 715; pol. Raztoki 900; pol. Ziajówka 740; poniżej H. Rycerzowa 1110; ponad g. Wiertalówka 1020; pot. Raztoka 855; las poniżej H. Przysłop 780; dol. Przegibka 780; pol. Kołyska 920; pot. Racza 770, 835; g. Mała Racza 815; pot. Wielka Jaworzyna 860; g. Będoszka Mała 900; g. Wielka Racza 1100; Królowa 760. P: H. Durajka 835; pot. Bystra 585; poniżej Uszczawnego 725; przeł. Przysłopy 840 ; dol. W Kotarnicy 735, 880; ponad Latynką 1000; dol. Do Jodłowcowej 890; g. Romanka 1350; E stok g. Kotarnica 935; dol. Kajdasówki 860; g. Skałka 1140; dol. W Ciemnym 900; k. pol. Bartek 1140; H. Szczawina 1060; m. Sznurkami a Dadokami 865; pot. Sikorczany Potok 735; dol. Solarzówki 495, 680; Kosarzyska 620; dol. Sopotni Wielkiej 840; g. Rysianka 1320; g. Pilsko 1365; 1420, las powyżej H. Mędralowej 1320; g. Palenica 1320; g. Szczawinka 1280; las poniżej H. Cebulowa 1195; pol. Kobyle Młaki 1000; m. H. Jodłowcową a H. Miziową 1400; H. Bieguńska 1150; g. Jaworzyna k. Pilska 990, 1090; g. Trzy Kopce 1200; dol. Z Wideł 950; dol. Śmierdzący Potok 750, 950; pot. poniżej Dziasek 630; H. Motykowa 1030; Na Piętrze 800; pot. Połom 780; pot. Z Gawłowskiego 700; dol. Nickuliny 600; pot. Potok Jakubowski 605, 630; dol. Stara Piła 870; pot. Kościelec 750; poniżej Herduli 695; Jastrzębie 720; dol. Głębokiego 580, 640, 690; pol. Kotrysia Polana 720; poniżej g. Bucioryska 760. BG: las m. Markowymi Szczawinami a przeł. Brona 1225; poniżej Akademickiej Perci 1300; poniżej Diablaka 1600; H. Kralowa 1320. J: dol. Grzechynki 450, 550; dol. Czernej 500; pot. Dejówka 600; Kolędowy Potok 650; dol. Głucha 650; Złabne 680; g. Surzyny 670; g. Janoszka 700; g. Baranówka 800; m. Chrząszczami i Toporami 800; dol. Magurki 830; poniżej g. Mędralowa 850; g. Magurka 870; g. Wełczon 875; przeł. Klekociny 890, 930; Opaczne 950; g. Czarniawa Sucha 1000; g. Jałowiec 1050; g. Mędralowa 1170.

Belonia herculina (Rehm. ex Lojka) Hazsl. - Kora bardzo starych buków; rg. d. 1 stan. P: rez. Rysianka 1050.

B. incarnata Th. Fr. \& Graewe ex Th. Fr. $[=$ Gongylia incarnata (Th. Fr. \& Graewe ex Th. Fr.) A. Zahlbr.] - Obumierające mchy; miejsca cieniste; kos. 1 stan. BG: Kościółki 1580.

Biatora carneoalbida (Müll. Arg.) Coppins [= Bacidia sphaeroides (Dicks.) A. Zahlbr.] - Obumierające mchy porastające stare buki w naturalnych lasach; $\mathrm{rg}$, d.

1 stan. P: rez. Rysianka 1000. 
B. chrysantha (A. Zahlbr.) Printzen in V. Wirth - Silnie zbutwiałe i prawie rozsypujące się pniaki iglaste albo kora drzew iglastych; rg. d.

1 stan. WR: Rycerki 620.

B. efflorescens (Hedl.) Erichs. [ = Lecidea efflorescens (Hedl.) Vain.] - Kora starych drzew liściastych, niekiedy iglastych, najczęściej płonne; rg. d., rg. g. 41 stan. WR: pot. Śrubita 975; las Na Kołysce 1000; las Orzeł 1030; H. Muńczoł 1100; g. Jaworzyna 1100; pol. Skrzadnita 1105; rez. Oszus (z apotecjami) 1150; g. Wielka Racza 1180; g. Rycerzowa Wielka (z apotecjami) 1195. P: leśniczówka Straceniec 775; H. Kupczykowa 840; pot. Kościelec (z apotecjami) 840; pot. Stara Piła 900; Polany Pod Soblówką 900; pot. Alacowa 925; g. Okrągła 925; g. Wilczy Groń 950; pot. Śmierdzący Potok 950; pot. Zająców Potok 1000; g. Prusów 1000; rez. Rysianka (z apotecjami) 1050, 1070, 1120; g. Magurka (z apotecjami) 1035; H. Wieprzska 1060; las poniżej H. Lipowskiej 1100; g. Jodłowcowa (z apotecjami) 1100; H. Bacmańska 1125; las poniżej H. Wieprzskiej (z apotecjami) 1150; pol. Bartek (z apotecjami) 1150; H. Pawlusia 1170; H. Łyśniowska 1190; H. Jodłowcowa 1200; g. Lipowska 1260. BG: las ponad H. Czarną 1140. J: H. Kamińskiego 1050.

B. cf. meiocarpa (Nyl.) Arnold [= Lecidea meiocarpa Nyl.] - Kora drzew liściastych rosnących w lasach naturalnych; rg. d.

1 stan. WR: pot. Śrubita 750.

Brodoa intestiniformis (Vill.) Goward [= Hypogymnia encausta (Sm.) W. R. Wats.) - Skały piaskowcowe; miejsca suche i widne; kos.

1 stan. BG: Diablak 1700.

Bryophaga gloeocapsa Nitschke ex Arnold [= Gloeolecta bryophaga (Koerb. ex Arnold) Vězda] - Obumierające mchy naziemne, niekiedy naga gleba, rzadko butwiejące pniaki, często obok dróg i ścieżek leśnych; zawsze miejsca cieniste, umiarkowanie wilgotne; pg., rg. d., rg. g., kos.

39 stan. WR: pot. Czadeczka 530; pot. Czerna 610; pot. Krążelka 670; Mandlówka 625; Tanistry 620; pot. Butorzy 680; Szczytkówka 750; pot. Danielka 800. P: pot. Potok Jakubowski 605; Żabnicka Rzeka 590; pot. Nickulina 500; pol. Kosarzyska 620; pot. Solarzówka 670; g. Kiczora nad Durajami 670; pot. Kajdasówka 685; dol. W Kotarnicy 735; dol. Do Jodłowcowej 775, 845; pot. Kościelec 750; pot. Z Gawłowskiego 685, 700; pot. Cięcinka 700; H. Durajka 835; pol. Alacowa 900; g. Sucha Góra 1000; pot. Glinna 1165, 1350; g. Szczawinka 1280; Kozi Grzbiet (Pilsko) 1300; g. Pilsko 1375, 1405, 1445. BG: Kościółki 1580; Akademicka Perć 1570. J: pot. Głucha 600; dol. Grzechynki 550; przeł. Klekociny 890; dol. Magurki 780; Surmiaków Potok 580.

Bryoria bicolor (Ehrh.) Brodo \& Hawksw. [= Alectoria bicolor (Ehrh.) Nyl.] - Kora starych, omszałych świerków, rzadziej jodeł i liściastych (głównie buków); rg. d., rg. g.

32 stan. P: H. Bacmańska 1125; H. Wieprzska 1130, 1175; rez. Rysianka 1130; pol. Bartek 1150; H. Bieguńska 1150; pot. Glinne 1200; g. Szczawinka 1200, 1310, 1315, 1350; g. Lipowska 1260, 1280, 1310, 1320; g. Rysianka 1130; H. Mędralowa 1280, 1290; g. Palenica 1320; g. Pilsko 1290, 1360, 1400; g. Romanka 1355, 1365. BG: las powyżej H. Czarnej 1260; las m. Markowymi Szczawinami a przeł. Brona 1280, 1310; Sokolica 1230, 1390; poniżej Diablaka 1610; Diablak 1725; pot. Kiczorka 1360. J: H. Kamińskiego 1100.

B. catharinae (Räs.) Bystr. [= Alectoria catharinae Rds.] - Kora starych świerków; rg. g.

1 stan. BG: las m. Markowymi Szczawinami a przeł. Brona 1280.

B. crispa (Mot.) Bystr. [ = Alectoria crispa Mot.] - Kora starych drzew (świerki, jodły, dęby, jarzębiny); rg. d., rg. g.

15 stan. WR: pot. Urwisko 750; g. Bednarów Beskid 1050. P: Sułki 660; pot. Nickulina 670; leśniczówka Straceniec 775; H. Rysianka 1150; G. Lipowska 1280; g. Pilsko 1360. J: m. g. Kamienną a g. Surzynówką 700; dol. Koszarawy 800; g. Babiarzówka 870; las Czerniawa 940; m. pol. Magurką a H. Kamińskiego 1100. 
B. fuscescens (Gyeln.) Brodo \& Hawksw. [= Alectoria fuscescens Gyeln.] - Kora i gałęzie drzew iglastych, rzadko liściastych (jarzębiny); rg. d., rg. g.

18 stan. WR: pot. Urwisko 750; g. Bednarów Beskid 1050. P: leśniczówka Straceniec 775; g. Okrą̧ła 940; g. Jaworzyna koło Pilska 1025; g. Magurka k. Trzech Kopców 1080; H. Łyśniowska 1190; H. Mędralowa 1280, 1350; g. Rysianka 1300; g. Szczawinka 1300, 1315, 1350; g. Lipowska 1310, 1320; g. Palenica 1320, 1340. BG: las m. Markowymi Szczawinami a przel. Brona 1310.

B. implexa (Hoffm.) Brodo \& Hawksw. [= Alectoria implexa (Hoffm.) Nyl.] - Kora starych świerków; rg. g.

1 stan. BG: las powyżej Markowych Szczawin 1280.

B. mirabilis (Mot.) Clauz. \& Roux [= Alectoria mirabilis Mot.] - Kora starych świerków; rg. g.

2 stan. BG: las ponad Markowymi Szczawinami 1280, las poniżej Małej Babiej 1310.

B. motykana (Bystr.) Bystr. [= Alectoria motykana Bystr.] - Kora starych świerków; rg. g.

2 stan. P: g. Pilsko (las nad H. Miziową) 1360. BG: las powyżej Markowych Szczawin 1280.

B. nadvornikiana (Gyeln.) Brodo \& Hawksw. [= Alectoria nadvornikiana Gyeln.] - Kora i gałęzie starych świerków, rzadko jodeł; rg. d., rg. g.

11 stan. P: rez. Rysianka 1130; H. Mędralowa 1280, 1290; g. Szczawinka 1300; g. Rysianka 1300; g. Lipowska 1310; g. Palenica 1340. BG: las powyżej H. Czarnej 1200; las m. Markowymi Szczawinami a przeł. Brona 1280; las poniżej Akademickiej Perci 1340; pot. Kiczorka 1300.

B. positiva (Gyeln.) Bystr. [= Alectoria positiva (Gyeln.) Mot.] - Kora i gałęzie drzew iglastych i liściastych ; rg. d., rg. g.

27 stan. WR: rezerwat Butorza 620, 630; pot. Plaskurówka 700, 710; pol. Juraszkowa 850; g. Muńczoł 1105; g. Będoszka Wielka 1120. P: Żabnicka Rzeka 600; leśniczówka Straceniec 775; pot. Stara Piła 780; pot. Zająców Potok 840; pot. Straceniec 870; pot. Bystra 875; Polany Pod Soblówką 900; pot. Śmierdzący Potok 910, 1090; Złotnice 925; pol. Krawcula 1000; H. Wieprzska 1060, 1100; H. Lipowska 1100; H. Mędralowa 1280, 1340; g. Lipowska 1320; g. Romanka 1350. BG: H. Kralowa 1255. J: dol. Głucha 680.

B. setacea (Ach.) Brodo \& Hawksw. [= Alectoria setacea Ach.] - Kora starych, niekiedy martwych lub karłowatych świerków; rg. g., kos.

2 stan. P: G. Rysianka 1300; g. Pilsko (Turniczka) 1400.

B. sophiae (Mot.) Bystr. [= Alectoria sophiae Mot.] - Kora starych świerków; rg. g.

1 stan. BG: las powyżej Markowych Szczawin 1280.

B. subcana (Nyl. ex Stizenb.) Brodo \& Hawksw. [ = Alectoria subcana (Nyl. ex Stzenb.) Gyeln.] - Kora starych świerków; rg. g.

3 stan. P: g. Szczawinka 1315. BG: las powyżej Markowych Szczawin 1280; poniżej Małej Babiej 1300.

B. vrangiana (Gyeln.) Brodo \& Hawksw. - Kora starych świerków; rg. g. 1 stan. P: g. Szczawinka 1315.

Buellia aethalea (Ach.) Th. Fr. - Bezwapienne piaskowce (naturalne skałki, stosy kamieni, luźne murki); rg. d., r. g., kos.

12 stan. WR: g. Praszywka Duża 950, 1030. P: Sopotnia Wielka 735; k. leśniczówki Glinne 750; g. Prusów 820, 965, 1000; g. Okrągła 930; pol. Krawcula 1035; g. Rysianka 1320; g. Pilsko 1420. J: przys. Opaczne 950.

B. disciformis (Fr.) Mudd - Kora drzew liściastych tworzących widne drzewostany albo rosnących pojedynczo; rg. d.

14 stan. WR: pot. Rycerka 630; Rycerki 655; Raztoki 700; pot. Urwisko 700; Żebrakówka 800; g. Orzeł 1030; g. Magura 1050; g. Pleskierówka 1085; H. Muńczoł 1100. P: pol. Kotrysia Polana 720; pot. Straceniec 870; H. Łyśniowska 1090; H. Pawlusia 1180; H. Jodłowcowa 1200. 
B. griseovirens (Turn. \& Borr. ex Sm.) Almb. [= Diplotomma betulinum (Zw.) Arnold] - Kora drzew liściastych; głównie w stanie płonnym; pg., rg. d. 27 stan. WR: pot. Czadeczka 545; dol. Cicha 600; Rycerki 600; pot. Plaskurówka 700; Raztoki 700; Żebrakówka 800; leśniczówka Pod Raczą 715; pot. Śrubita 750; Słonkówka 750; H. Przysłop 950; g. Praszywka Duża 750. P: Złatna 600; Żabnicka Rzeka 600; pot. Straceniec 695, 775, 870; pol. Koziorka 800; H. Bieguńska (z apotecjami) 1150. J: dol. Czernej 500; Kępy 500; Boguniówka 600; Kolędowy Potok 650; Złabne 680; dol. Bystrej 800; Podjałowiec 930.

B. leptocline (Flot.) Massal. - Bezwapienne piaskowce, głównie naturalne skałki, gołoborza i piargi, rzadziej stosy kamieni oraz luźne murki; miejsca suche i widne; rg. d., rg. g., kos.

16 stan. WR: g. Klimasy 710; Szczotka 870; g. Jaworzyna 900; g. Będoszka Wielka 1100; H. Mała Racza 1135; H. Rycerzowa 1140 P: Dziaski 735; Milówki 900; g. Okrągła 930; H. Malarka 1000; g. Kotarnica 1010; poniżej H. Majerkowej 1075; H. Jodłowcowa 1160, 1200; g. Pilsko (Turniczka) 1400. BG: Sokolica 1370.

B. ocellata (Flot.) Koerb. [=B. verruculosa auct.] - Bezwapienne piaskowce (stosy kamieni, kamienie leżące na nieużytkach, nad potokami); miejsca widne i suche; pg., rg. d.

7 stan. WR: g. Ochodzita 760. P: k. leśniczowki Glinne 760; g. Abrahamów 830; pol. Na Boruć 890. BG: Sokolica 1370. J: dol. Zasepnicy 440; g. Witkówka 650 .

B. schaereri De Not. - Nagie drewno, np. murszejące pniaki iglaste; rg. d. 1 stan. J: dol. Bystrej 600 .

Calicium abietinum Pers. - Murszejące drewno pniaków, okorowane i martwe drzewa oraz kora żywych drzew iglastych; rg. d., rg. g.

19 stan. WR: Rycerki 620; pot. Radecki 700; rez. Śrubita 780; g. Klin 850; g. Bednarów Beskid 950. P: pot. Straceniec 750; g. Romanka 1075; H. Bacmańska 1130; g. Trzy Kopce 1160; H. Bieguńska 1200; g. Lipowska 1260; pot. Glinna 1260; g. Rysianka 1320; g. Pilsko 1280. BG: nad górnym Płajem 1200; na Sokolicę przy górnym Płaju 1040. J: g. Jałowiec 1030; S stok g. Jałowiec 1000; m. g. Jałowiec a Opacznem 1010.

C. lenticulare Ach. [ = C. schaereri sensu Nadv.] - Kora starych świerków; rg. g. 2 stan. BG: las nad Markowymi Szczawinami 1290; powyżej górnego Plaja 1160.

C. salicinum Pers. - Murszejące pniaki, pnie okorowanych martwych drzew liściastych i iglastych; rg. d., rg. g.

11 stan. WR: rez. Śrubita 790, 900. P: rez. Rysianka 1100,1130; H. Redykalna (Boraczy Wierch) 1140; las poniżej pol. Bartek 1150; H. Bieguńska 1200; g. Lipowska 1280; g. Romanka 1350. BG: Markowe Szczawiny 1190. J: dol. Bystrej 600; g. Beskidek 1010.

C. trabinellum (Ach.) Ach. - Murszejące pniaki i okorowane martwe drzewa iglaste; rg. d., rg. g.

24 stan. WR: Rycerki 640; pot. Danielka 700; pot. Radecki 700; g. Klin 850; g. Bednarów Beskid 950. P: g. Romanka 1075, 1360; H. Wieprzska 1040; H. Bieguńska 1280; g. Pilsko 1375; rez. Rysianka 1100; g. Lipowska 1300; g. Szczawinka (Sypurzeń) 1300; g. Rysianka 1320. BG: las m. Markowymi Szczawinami a przeł. Brona 1310; las poniżej Akademickiej Perci 1235; pot. Kiczorka. J: dol. Magurki 750; g. Mędralowa 1150.

C. viride Pers. - Kora starych drzew iglastych i liściastych, rzadko murszejące drewno; rg. d., rg. g.

21 stan. WR: rez. Śrubita 810; rez. Oszus 950; las Orzeł 965; pot. Śrubita 975; g. Bugaj 1050. P: pot. Śmierdzący Potok 760; pot. Z Gawłowskiego 770; pot. Straceniec 750; pot. Połom 790; pot. Stara Piła 900 ; H. Motykowa 1100; las poniżej H. Bieguńskiej 1150; las powyżej H. Wieprzskiej 1210; g. Rysianka 1300; g. Lipowska 1310; g. Romanka 1350, 1360; g. Pilsko 1300. BG: las m. Markowymi Szczawinami a przeł. Brona 1255, 1310; las poniżej Akademickiej Perci 1235, 1340. 
Caloplaca cerina (Ehrh. ex Hedw.) Th. Fr. - Mchy epifityczne lub kora drzew (stare buki, topole i wierzby przydrożne) niekiedy omszone skały piaskowcowe; pg., rg. d.

6 stan. WR: g. Łysica 550. P: Złatna 600; H. Górowa 1100; H. Bacmańska 1125; H. Pawlusia 1190; H. Rysianka 1200 .

C. chlorina (Flot.) Oliv. - Bezwapienne piaskowce, np. omurowanie potoku koło źródła; rg. d.

1 stan. WR: Sól 560.

C. citrina (Hoffm.) Th. Fr. - Betónowe podłoże (słupki, ogrodzenia, studnie, mostki, podmurówki), rzadko kora drzew przy korzeniach (stare samotnie rosnące dęby); pg., rg. d., kos.

11 stan. WR: Milówka 450; Nieledwia 470; Rycerka 500; Rajcza 520; Tanistry 555; Kotłówka 600. P: pot. Nickulina 555; pol. Bura Polana 650. BG: S stok Diablaka 1600. J: Grzechynia 480; Baranówka 700.

C. decipiens (Arnold) Blomb. \& Forssell - Skałki wapienne oraz podłoże betonowe i murowane (słupki betonowe, parkany, studnie, podmurówki); pg., rg. d., kos.

7 stan. WR: Milówka 450; pot. Nieledwianka 460; Rajcza 529; Zwardoń 660. P: g. Grojec 610. BG: południowy stok Diablaka 1600. J: Głuszki 400.

C. dolomiticola (Hue) A. Zahlbr. - Wapienie oraz silnie wapniste piaskowce, rzadziej na podłożu betonowym; miejsca widne i suche; pg., rg. d.

12 stan. WR: Rycerka 515; Karchówka 565; Skomisko 680; pot. Dzięboki 770; Sporysz 420; g. Grojec 610. P: Sopotnia Wielka 850, 870; Tokarnia 890. J: dol. Grzechynki 450; dol. Czernej 500; dol. Bystrej 750; g. Wełczon 840.

C. flavovirescens (Wulf.) Dalla Torre \& Sarnth. - Wapniste piaskowce; miejsca suche i widne; pg., rg. d.

9 stan. WR: Rycerka 515; g. Łysica 550; g. Hutyrów 740. P: Sporysz 420; g. Grojec 610. J: dol. Zasepnicy 440; dol. Grzechynki 450; dol. Czernej 500; pot. Surmiaków 550.

C. herbidella (Hue) H. Magn. - Kora starych drzew liściastych rosnących na skraju hal lub pojedynczo (buki, jawory, rzadziej klony, dęby i jesiony); rg. d. 15 stan. WR: g. Rachowiec 850; g. Pleskierówka 1090. P: Żabnicka Rzeka 600; pol. Bura Polana 660; dol. Do Jodłowcowej 850; g. Kotarnica 1000; H. Łyśniowska 1090, 1190; g. Jodłowcowa 1100; H. Wieprzska 1120, 1150; H. Pawlusia 1190; H. Rysianka 1200. J: H. Kamińskiego 1100; g. Mędralowa 1150.

C. holocarpa (Hoffm. ex Ach.) Wade [ = C. lithophila H. Magn., C. pyracea (Ach.) Th. Fr.] - Kora drzew liściatych, gałęzie lub martwe drewno (parkany, ogrodzenia, poręcze mostów itp.) oraz bezwapienne lub wapniste piaskowce (skałki, głazy nad brzegami potoków i rzek, stosy kamieni), rzadziej wapienie i beton; miejca suche i widne; pg., rg. d., rg. g., kos.

43 stan. WR: pot. Nieledwianka 460; pot. Krążelka 510; pot. Z Głębokiego 550; g. Ochodzita 760; pot. Pietraszyna 840; g. Łysica 550; pot. Rycerka 580; pot. Danielka 650; Soblówka 670; g. Hutyrów 700; pol. Masarka 720; pot. Dzięboki 770. P: Sporysz 390, 420; Juszczyna 430; g. Grapa Żar 430; pol. Bugaj 580; pot. Bystra 510; g. Kubiesówka 800; Tokarnia 890; H. Motykowa 1050; H. Redykalna 1140; g. Skałka 1195; H. Bieguńska 1200; Złatna 640; pol. Kotrysia Polana 730; g. Pilsko 1385, 1420. BG: Cyl 1515; Kościółki 1510; S stoki Diablaka 1600. J: dol. Zasepnicy 380, 440; dol. Grzechynki 450; m. Grzechynią a Skupniówką 450; dol. Czernej 500; dol. Kalinki 540; dol. Głucha 580; pot. Surmiaków 700; dol. Bystrej 700; g. Surmiaków Groń 730; g. Wełczon 850; pol. Skalaniec 850; g. Mędralowa 1170.

C. lactea (Massal.) A. Zahlbr. - Kamienie wapienne, np. w opuszczonych kamieniołomach; miejsca suche i widne; pg.

2 stan. P: Sporysz 390; Kopce k. g. Grojec 470. 
C. tiroliensis A. Zahlbr. - Mchy porastające pnie starych buków; normalnie gatunek rośnie na mchach i szczątkach roślin na podłożu wapiennym; rg. g.

1 stan. P: H. Górowa 1100.

C. variabilis (Pers.) Müll. Arg. - Suche i widne skałki wapienne; pg. 1 stan. P: Sporysz 420.

Candelaria concolor (Dicks.) Stein - Kora drzew liściastych, zwłaszcza rosnących pojedynczo lub przydrożnych: pg., rg. d.

22 stan. WR: Nieledwia 480; Rajcza 520; Ujsoły 530; Spylowie 550; Zawodzie 610; Słonkówka 625; Raztoki 700. P: Jeleśnia 415; Juszczyna 430, 450; Trzebinia 425; Kupcanki 475; Krzyżowa 520; Korbielów Dolny 550; Kamienna 650; Złatna 600. J: dol. Zasepnicy 380; Jarliki 500; Dolinka 620; Semikówka 550; Wełcza 630; Spikówka 650; Spyrki 700.

Candelariella aurella (Hoffm.) A. Zahlbr. - Wapienie oraz silnie wapniste piaskowce lub obiekty murowane i betonowe; miejsca widne i suche; pg., rg. d. 12 stan. WR: Rycerka 530; g. Ochodzita 760; pot. Rycerka 600; Soblówka 670; pol. Masarka 720. P: Sporysz 390, 420; pol. Bugaj 580; g. Grojec 610; pot. Zająców Potok 800; H. Durajka 835; g. Skałka 1195.

C. coralliza (Nyl.) H. Magn. - Skały piaskowcowe; kos.

1 stan. BG: Diablak 1700.

C. reflexa (Nyl.) Lettau - Kora starych drzew liściastych; gatunek prawdopodobnie częstszy, lecz przeoczony; rg. d.

1 stan. P: H. Boracza 865.

C. vitellina (Hoffm.) Müll. Arg. - Bezwapienne lub słabo wapniste piaskowce, również beton (parkany, słupki, mosty), sporadycznie kości, stare drewno parkanów albo przy korzeniach starych samotnych drzew liściastych; pg., rg. d., rg. g., kos. 194 stan. WR: pot. Sucha Nieledwianka 520; Pochodzita 760; g. Ochodzita 820; Pietraszyna 840; g. Zabawa 600, 760; g. Kiczorka 795; Wierch Czadeczka 680; pot. Czadeczka 510; poniżej Bestwin 500; Myto 675; g. Podgórka 795; g. Kiczora 680; Tomusie 600; Głębokie 660; g. Klimasy 710; pot. Z Głębokiego 550; g. Rachowiec 850, 910; g. Hutyrów 670; g. Skalanka 800; dol. Ujsoły 520; Rycerka Dolna 550; Szczotka 870; g. Oźna 780, 920, 930, 950; g. Solański Groń 705; pot. Rycerka 580; g. Łysica 650; Płaskonków 650; Szczytkówka 870, 875; dol. Danielki 650; m. g. Jaworzyna a g. Magurka 945; g. Jaworzyna 900, 1020; g. Praszywka Duża 980; g. Muńczoł 1120; pol. Wyrobniówka 900; m. Podścigłowem a Magurą 770; Magura 850; pol. Bułkowa 760; Przysłop Połucki 870; Rycerki 655; Młada Hora 1120; g. Kiczorka 985; Skomisko 680; pol. Cerla 1025; pol. Joneczkowe Rycerki 715; pol. Raztoki 750; Pod Raczą 715; pol. Majów 885; Będoszka Wielka 1100; pol. Kołyska 1010; Rycerzowa 1150, 1170; H. Mała Racza 1120; g. Wielka Racza 1335. P: g. Grojec 610; pol. Bugaj 580; g. Grapa Żar 430; Juszczyna 430; g. Groń nad Przyłękowem 700; pot. Suseński 480; g. Przypór 855; pot. Bystra 510; Duraje 610; g. Jastrzębica 750; Na Skale 860; g. Magura 850, 870; g. Juszczynka 880; g. Abrahamów 700, 780; Sopotnia Wielka 735; g. Kotarnica 1010, 1015; g. Łazy 995; Tokarnia 780, 890; H. Majerkowa 1075; dol. W Ciemnym 1170; dol. Do Jodłowcowej 725; pol. Na Boruć 840, 895; g. Prusów 1000, 1005; g. Malarka 1050; g. Baścikówka 810, 850; H. Wieprzska 1060, 1100; Kolonia 750; pol. Buczynka 880; Milówki 700, 785, 920; pol. Alacowa 925; m. Sznurkami a Dadokami 865; H. Jodłowcowa 1200; leśniczówka Glinne 750; g. Rysianka 1240, 1300; g. Pilsko 1385, 1420; pol. Szczyrbowe Młaki 890; H. Skórzacka 1125; H. Bieguńska 1160; H. Lipowska 1140, 1350; g. Sucha Góra 980, 1000, 1020, 1040; Graberki 900; H. Redykalna 1060, 1140; pol. Gruszkowa 1000; H. Motykowa 1050, 1060; Dziaski 735; Zapolanka 850; Zagroń 845; g. Bucioryska 795; pot. Z Gawłowskiego 645; g. Okrągła 830, 930; pot. Głębokie 580, 630; g. Długi Groń 880; pol. Krawcula 1035; g. Kotelnica 760; Polany Pod Soblówką 900. BG: pot. Suchy 1365; Cyl 1515; H. Czarna 1080; Kościółki 1510, 1600; m. Kościółkami a Diablakiem 1625; S stok pod Diablakiem 1600, 1610, 1650, 1660; Diablak 1700, 1725. J: g. Czerniańska 450, 500; g. Gawronowa 580; Drwalówka 690; g. Kamienna 700; g. Ostra Górka 600; g. Grzechynia 450; Kubiasiaki 690; g. Skupniówka 600, 650; g. Kwakowa 670; g. Magurka 870; g. Surzynówka 800; g. Witkówka 650; Topory 700; dol. Gołyńki 520; dol. Kalinki 540; g. Kiczora 900; g. Lachów Groń nad Skawicą 600; Roztoki 620; Figury 820; Jałowiec 750; Kolędówka 800; Polanki 
Pierglesowe 680; g. Surmiaków Groń 730; Baranówka 700; pot. Surmiaków Potok 550; H. Trzebuniaków 1050; H. Janoszkowa 1020; pol. Skalaniec 900; g. Biały Wierch 1040; g. Kiklówka 745; g. Wełczon 840; dol. Bystrej 700; dol. pot. Głucha 580, 730; g. Przyborówka 850.

C. xanthostigma (Pers.) Lettau - Kora drzew liściastych, głównie przydrożnych i samotnie rosnących; pg., rg. d.

60 stan. WR: Kasperki 670; pot. Czadeczka 500, 580; Tarliczne 590; pot. Krążelka 500; Obrot 615; m. górami Kiczora i Popręcina 685; Karchówka 565; Szpaki 570; pol. Butorowe Grapy 540; Rajcza 500; Rycerka Dolna 525; Ujsoły 530; pot. Rycerka 580, 590; Spylowie 550; Szczotka 900; dol. Radeckiego 670; g. Jaworzyna 885, 900; g. Praszywka Duża 970; Zawodzie 610; Podścigłów 700; Słonkówka 750; Żebrakówka 800; Kolonia 670; g. Muńczoł 990; Smereków Wielki 750; Skomisko 680; pot. Racza 755. P: Trzebinia 425; Kupcanki 475; Juszczyna 450; Węgierska Górka 425; Cisiec 650; Kamienna 650; Sopotnia Wielka 620; przeł. Przysłopy 860; Żabnicka Rzeka 600; g. Jodłowcowa 1100; g. Prusów 1000; pol. Koziorka 800; H. Boracza 865; H. Pawlusia 1170; H. Bacmańska 1125; Złatna 610; Sułki 665; dol. Nickuliny 500; g. Długi Groń 850. J: Wygoda 420; dol. Czernej 430, 500; Pytel 650; g. Drwalowa 680; Kiecka 700; g. Surzynówka 700; poniżej g. Przyborówka 860; przeł. Klekociny 890; H. Trzebuniaków 1030.

Carbonea vitellinaria (Nyl.) Hertel [= Lecidea vitellinaria Nyl.] - Plechy Lecanora polytropa, L. intricata $i$ Candelariella vitellina; rg. d.

1 stan. WR: H. Rycerzowa 1140.

C. vorticosa (Flk.) Hertel [= Lecidea vorticosa (Flk.) Koerb.] - Bezwapienne piaskowce (naturalne skałki, kamienie luzem na gołoborzach i po halach); rg.d., rg. g., kos.

3 stan. P: g. Okrągła 930; g. Skałka 1195; g. Pilsko 1400.

Catillaria erysiboides (Nyl.) Th. Fr. - Nagie drewno murszejących pniaków; miejsca widne i suche; rg. d.

2 stan. J: pot. Głucha 700; przys. Figury 870.

C. cf. lenticularis (Ach.) Th. Fr. - Ocienione, pionowe skałki piaskowcowe nie zawierające węglanu wapnia; rg. d.

1 stan. J: pot. Magurka 750.

C. nigroclavata (Nyl.) Schuler - Murszejące pniaki na zrębach; normalnie rośnie na korze drzew liściastych; rg. d.

1 stan. WR: pot. Danielka 700.

Catinaria atropurpurea (Schaer.) Vězda \& Poelt $[=$ Catillaria atropurpurea (Schaer.) Th. Fr.] - Stare murszejące pniaki; rg. d.

2 stan. WR: k. pol. Skrzadnitej 1105. J: powyżej Drwalówki 640.

Catolechia wahlenbergii (Ach.) Koerb. [ = Buellia pulchella (Schrad.) Tuck.] - Według STEINA (1872) znaleziony był na szczycie Babiej Góry; obecnie nie odszukany.

Cetraria aculeata (Schreb.) Fr. [= Cornicularia aculeata (Schreb.) Ach.] - Gliniasto-piaszczysta gleba, np. między jałowcami, nieużytki, wrzosowiska; rg. d., rg. g., kos.

8 stan. WR: pot. Głęboki 700; g. Burów Groń 690; g. Sobański Groń 730; g. Hutyrów 740. BG: Sokolica 1370; Główniak 1570; Diablak 1660, 1700.

C. ericetorum Opiz $[=C$. crispa (Ach.) Nyl. $]$ - Gliniasto-piaszczysta gleba na nieużytkach, polanach, wrzosowiskach; rg. d.

3 stan. WR: g. Burów Groń 690; Szczytkówka 725; g. Sobański Groń 730.

C. islandica (L.) Ach. - Gleba na nieużytkach, wrzosowiskach, m. jałowcami, wśród traw po halach i polanach, obok dróg leśnych; rg. d., rg. g., kos. 
80 stan. WR: g. Kiczorka 590, 700, 785; Staronie 760; g. Podgórka 785; pot. Głęboki 700; Szczotka 785; g. Kłokocz 730; g. Hutyrów 700; Stawiska 770; Szczytkówka 735; g. Praszywka Duża 1040; pol. Gardasówka 830; m. Podścigłowem a Magurą 770; Na Kołysce 1000; H. Przysłop 960; g. Rycerzowa 1160; g. Mała Racza 1175; g. Kịula 1100. P: g. Groń nad Przyłękowem 700; g. Żor 700, Duraje 835; H. Durajka 835; g. Juszczynka 880; g. Abrahamów 830; g. Palenica 710; g. Prusów 965; Milówki 920; g. Romanka 1350; g. Baścikówka 880; g. Rysianka 1320; g. Pilsko 1390, 1400, 1420, 1425, 1445, 1450, 1460, 1470, 1480, 1490, 1535; g. Palenica 1320; H. Lipowska 1250; g. Boraczy Wierch 1240; H. Mędralowa 1340; g. Bucioryska 795. BG: Kępa 1520, 1530; Kościółki 1500, 1510, 1560, 1580, 1600; Główniak 1570; Akademicka Perć 1525, 1555, 1670; przeł. Brona 1420; m. Kościółkami a Diablakiem 1625; Diablak 1650, 1660, 1665, 1680, 1715, 1725; S stok Diablaka 1580, 1600, 1610. J: g. Czerniańska 500; dol. Czernej 500; dol. Kalinki 520, 700; g. Ostra Górka 600; g. Drwalowa 690; przys. Smeraki 700; g. Kamienna 740; g. Jaworzyna blisko g. Szelust 870; g. Kiczora 890; Podjałowiec 950, 990; g. Biały Wierch 1040; g. Lachów Groń nad Bystrą 1045.

Cetrelia cetrarioides (Del. ex Duby) W. Culb. \& C. Culb. - Kora drzew liściastych w naturalnych lasach; pg., rg. d.

25 stan. WR: g. Bednarów Beskid 1000; las Orzeł 1030; H. Rycerka 1100; g. Muńczoł 1100; g. Będoszka Wielka 1100; g. Jaworzyna k. g. Bugaj 1150; g. Rycerzowa Wielka 1195; g. Wielka Racza 1200. P: leśniczówka Janikówka 415; Żabnicka Rzeka 600; H. Łyśniowska 1090, 1190; H. Lipowska 1100; rez. Rysianka 1100; H. Wieprzska 1120; H. Bacmańska 1125; H. Bieguńska 1150; H. Jodłowcowa 1200. J: dol. Zasepnicy 550; Roztoki 700; m. g. Jałowiec a g. Lachów Groń 810; poniżej Podjałowca 850; H. Kamińskiego 1050; g. Jałowiec 1100; g. Mędralowa 1150.

C. olivetorum (Nyl.) W. Culb. \& C. Culb. - W podobnych miejscach jak gatunek poprzedni, zwykle razem $\mathrm{z}$ nim, ale w miejscach widniejszych; rg. d.

5 stan. WR: g. Bednarów Beskid 1000; las. Orzeł 1030. P: rez. Rysianka 1100; H. Łyśniowska 1190; H. Jodłowcowa 1200.

Chaenotheca brachypoda (Ach.) Tibell [= Coniocybe sulphurea (Retz.) Nyl.] - Butwiejące drewno na pniach starych lub obumarłych drzew (buki, jodły); miejsca cieniste lub mroczne; rg. d., rg. g.

7 stan. WR: las Orzeł 980; rez. Oszus 950, 1000. P: rez. Rysianka 1050, 1100, 1300; H. Wieprzska 1130; g. Pilsko 1350. BG: m. Markowymi Szczawinami a przeł. Brona 1310.

Ch. brunneola (Ach.) Müll. Arg. - Butwiejące drewno pniaków, głównie iglastych; miejsca cieniste; rg. d.

2 stan. WR: rez. Oszus 1000. P: k. Zapolanki 1000.

Ch. chrysocephala (Turn. ex Ach.) Th. Fr. - Kora drzew iglastych, rzadko liściastych, zwykle w naturalnych drzewostanach, nad potokami górskimi itp.; pg., rg. d., rg. g.

56 stan. WR: pot. Czadeczka 570; Podścigłów 700; pot. Urwisko 700; pot. Danielka 720; pot. Pętkówka 725; g. Bednarów Beskid 920; las Orzeł 980; rez. Oszus 1050. P: pot. Fułatów 520; pot. Jakubowski Potok 645, 840; pot. Śmierdzący Potok 760; pot. Połom 780; pot. Kościelec 735; pot. Z Gawłowskiego 770; pot. Romanka 710; Sikorczany Potok 700; pot. Straceniec 750; pot. Sopotnia Mała 700; pot. Buczynka 800; pot. Bystra 875; Zająców Potok 840, 910; Szeroki Kamieniec 900; rez. Rysianka 1100; H. Wieprzska 1175; pol. Między Młaki 1200; las m. H. Lipowską a H. Bieguńską 1280; H. Miziowa 1220; g. Lipowska 1260; g. Szczawinka 1300; g. Romanka 1340; g. Palenica 1340; g. Rysianka 1320; g. Pilsko 1320, 1360. BG: las poniżej H. Czarnej 1040; las poniżej Sokolicy 1090; las ponad H. Czarną 1200; m. Markowymi Szczawinami a przeł. Brona 1310; las poniżej Akademickiej Perci 1235, 1340; H. Kralowa 1120; pot. Kiczorka 1395. J: dol. Bystrej 800, 850; dol. Czernej 580; g. Drwalowa 650; dol. Grzechynki 450; $\mathrm{m}$. Jaworzynką a Kiczorą 560; dol. Kalinki 700; dol. Magurki 750; pot. Opaczny 700; przys. Roztoki 700; pot. Stracony Potok 600; Pytel 550; dol. Zasepnicy 440.

Ch. ferruginea (Turn. ex Sm.) Mig. [= C. melanophaea (Ach.) Zw. $]$ - Kora drzew iglastych rosnących najczęściej nad potokami; pg., rg. d. 
12 stan. WR: pot. Czadeczka 530, 570; pot. Danielka 720. P: Sikorczany Potok 700; pot. Romanka 710; pot. Kościelec 730; Zająców Potok 910. J: dol. Czernej 580; m. Jaworzynką a Kiczorą 560; dol. Magurki 750; pot. Stracony Potok 600; dol. Zasepnicy 550.

Ch. furfuracea (L.) Tibell [= Coniocybe furfuracea (L.) Ach.] - Rozsypujące się drewno oraz butwiejąca kora drzew iglastych, rzadziej liściastych (głównie w jamkach między korzeniami), ziemia u nasady pni drzew w naturalnych drzewostanach, rzadko podłoże skalne, np. jamki między kamieniami luźnych murków; pg., rg. d., rg. g.

53 stan. WR: Pedech 625; las Orzeł 980, 985; Na Praszywce 825; pot. Mała Jaworzyna 775; rez. Oszus 1085; U Jurzycowej 670; pol. Skrzadnita 1105; pol. Głowa 950; Podścigłów 700; g. Bednarów Beskid 940; Wiertanówka 630; Słonkówka 625; Soblówka 700; pot. Danielka 710; g. Hutyrów 680. P: pol. Kosarzyska 620, 640; H. Wieprzska 1175; H. Miziowa na Romance 1075; H. Bieguńska 1150; g. Lipowska 1260; W Kotarnicy 820; W Ciemnym 830; pot. Kajdasówka 740; pot. Glinna 1165, 1300; Jakubowski Potok 605 ; pot. Bystra 875; pot. Stara Piła 740; Zająców Potok 605; pot. Kościelec 760; pot. Z Gawłowskiego 685; pot. Studziański 635; pot. Solarzówka 670; Bura Polana 700; Polany Pod Soblówką 900; pot. Straceniec 750; Szeroki Kamieniec 780; g. Romanka 1300; rez. Rysianka 1090; pot. Sopotnia Wielka 850; H. Cebula 1200; leśniczówka Janikówka 450. BG: pot. Kiczorka 1130. J: dol. Bystrej 850; dol. Czernej 580; dol. Wilkówki 475; dol. Kalinki 700; dol. Magurki 750; pot. Opaczny 700; Roztoki 700; k. Siwcówki 600; g. Skupniówka 600; dol. Zasepnicy 440; Złabne 680.

Ch. phaeocephala (Turn.) Th. Fr. - Kora starych świerków; rg. g. 1 stan. BG: las powyżej Markowych Szczawin 1290.

Ch. stemonea (Ach.) Müll. Arg. [ = C. aeruginosa auct.] - Kora drzew iglastych u nasady pni, jamki między korzeniami lub murszejące pniaki; cieniste miejsca; rg. d., rg. g.

10 stan. WR: Płaskonków 650; rez. Śrubita 790; rez. Oszus 1085. P: Jakubowski Potok 700; rez. Rysianka 1110; las poniżej H. Mędralowa 1250; g. Lipowska 1260; g. Pilsko 1360. BG: m. Markowymi a Sulowymi Szczawinami 1160. J: dol. Magurki 750.

d., rg. g.

Ch. trichialis (Ach.) Th. Fr. - Kora drzew iglastych oraz murszejące pniaki; rg.

12 stan. WR: g. Trojaki 615; Gumółki 700; pot. Śrubita 780. P: pot. Nickulina 670; pot. Straceniec 750; rez. Rysianka 1050, 1080; H. Jodłowcowa 1200; g. Romanka 1300; g. Pilsko 1375. BG: las powyżej Markowych Szczawin 1220. J: dol. Magurki 750.

Ch. xyloxena Nádv. [ $=$ C. nudiuscula (Schaer.) Nádv.] - Murszejące pniaki iglaste; cieniste miejsca; rg. d., rg. g.

27 stan. WR: Mandlówka 625; pot. Danielka 700; pot. Rycerka 700; Płaskonków 680; g. Hutyrów 680; pot. Płaskurówka 710; g. Jaworzyna 865; g. Klin 850; rez. Oszus 950. P: pot. Głęboki 650; pot. Nickulina 670; pot. Solański 680; Korbielów 590, 600; Kotrysia Polana 780; Uszczawne 800; g. Długi Groń 820; pot. Straceniec 780; H. Wieprzska 1050; poniżej H. Lipowskiej 1100; poniżej H. Bieguńskiej 1150; powyżej H. Wieprzskiej 1175; g. Romanka 1010; g. Rysianka 1300; g. Pilsko 1360, 1400. BG: lasं poniżej Akademickiej Perci 1235; H. Czarna 1040. J: dol. Opacznego 700.

Chaenothecopsis consociata (Nádv.) A. Schmidt [= Calicium consociatum Nadv.] - Plechy porostu Chaenotheca chrysocephala rosnącego głównie na świerkach; rg. g.

3 stan. P: g. Romanka 1360; g. Rysianka 1280. GB: pot. Kiczorka 1360.

Ch. pusiola (Ach.) Vain. - Butwiejące pniaki świerkowe; rg. d.

2 stan. BG: przeł. Krowiarki 1020 (det. A. TrTov). J: dol. Bystrej 600.

Ch. viridialba (Krempelh.) A. Schmidt [= Mycocalicium cinerascens (Nyl.) Vain.]

- Murszejące pniaki; wilgotniejsze miejsca; rg. d.

1 stan. WR: pot. Radecki 710. 
Chromatochlamys muscorum (Fr.) Mayrh. \& Poelt [= Microglaena muscorum (Fr.) Th. Fr.] - Obumierające mchy na pniach po starych bukach; rg. d. 1 stan. P: H. Rysianka 1190.

Chrysothrix candelaris (L.) Laundon [= Lepraria candelaris (L.) Fr.] - Kora drzew iglastych, głównie jodeł; miejsca cieniste i bardziej wilgotne; rg. d.

17 stan. WR: g. Trojaki 615. P: pot. Nickulina 670; pot. Straceniec 695, 750; Jastrzębie 720; Szeroki Kamieniec 790; Zająców Potok 840, 940; pot. Stara Piła 850. BG: las poniżej Sokolicy 1090; las poniżej H. Czarna 1040. J: dol. Grzechynki 450; dol. Czernej 580; dolinka poniżej g. Witkówka 580; Siwcówka 600; dol. Kalinki 700; Roztoki 700.

Cladina arbuscula (Wallr.) Hale \& W. Culb. [= Cladonia sylvatica auct.] - Gleba wśród traw na nieużytkach, wśród kosodrzewiny, w borówkach; pg., rg. d., rg. g., kos.

27 stan. WR: Rycerka 560; pot. Głęboki 700; g. Klimasy 710; g. Popręcina 775; Płaskonków 600; pol. Majów 825; g. Kikula 1100; g. Jaworzyna 1020; g. Mała Racza 1175. P: Za Kopcem 600; g. Jastrzębica 750; g. Kiczora 800; g. Okrągła 850; Zapolanka 850; g. Pilsko 1400, 1500. BG: Cyl 1485; Kościółki 1580; Akademicka Perć 1590; Diablak 1650, 1680; 1710. J: dol. Czernej 430; g. Lachów Groń nad Skawicą 600; g. Zimna 920.

C. ciliata Stirt. var. tenuis (Flk.) Ahti \& M. J. Lai [= Cladonia tenuis (Flk.) Harm.] - Gleba na nieużytkach i między kosodrzewiną; pg., rg. d., rg. g., kos. 11 stan. WR: g. Kiczorka 590; g. Hutyrów 600; Szczytkówka 735. P: g. Grapa Żar 550; g. Jastrzębica 750; g. Kiczora nad Ujsołami 780; g. Kiczorka 835; g. Pilsko 1460. J: m. g. Witkówka a Kudyjówką 500; g. Czerniańska 500, 550; g. Lachów Groń nad Skawicą 550, 570.

C. mitis (Sandst.) Hustich [= Cladonia mitis Sandst.] - Gleba wśród traw, wrzosów, jałowców, rzadko na murszejącym drewnie pniaków; pg., rg. d., rg. g., kos. 27 stan. WR: g. Syberia 550; g. Kiczorka 590; m. Pochodziłą a Pańską Łąką 700; m. Krutakami i Tarlicznym 635; g. Popręcina 785; g. Podgórka 770; Popręcinka 700; Młaki 700; g. Klimasy 710; Rycerka 560; Szczotka 870; g. Oźna 950; g. Burów Groń 685; Szczytkówka 735; g. Jaworzyna 1020; g. Praszywka Mała 850; g. Kotarz 1110; Królowa 780. P: g. Przypór 880; pot. Loraniec 480; g. Kiczora 800; g. Malarka 1050; dol. Rokitniak 600; g. Sucha Góra 960; Basiówka 700. BG: Kępa 1520; Cyl 1485.

C. rangiferina (L.) Nyl. [= Cladonia rangiferina (L.) Web. ex Wigg.] - Gleba wśród traw, borówek itp.; pg., rg. d., rg. g., kos.

31 stan. WR: pot. Głęboki 700; g. Kiczorka 780; Płaskonków 600, 650; g. Łysica 650; pot. Radecki 670; g. Burów Groń 685; Szczytkówka 735; pol. Majów 825; g. Praszywka Mała 850; g. Jaworzyna 1020; g. Mała Racza 1175; g. Rycerzowa 1205. P: g. Grapa Żar 500; przys. Basiówka 700; g. Kotelnica 750; Zapolanka 850; g. Magura 870; g. Pilsko 1360, 1450, 1500. BG: Kępa 1520; Cyl 1485; m. Kościółkami a przeł. Brona 1490; Kościółki 1580; Akademicka Perć 1590; Diablak 1600. J: dol. Czernej 430; g. Jaworzyna k. Szelusta 900.

C. stygia (Fr.) Ahti - Gleba wśród kosodrzewiny; kos.

1 stan. P: g. Pilsko 1400.

Cladonia amaurocraea (Flk.) Schaer. - Według SuZY (1951) rośnie na Babiej Górze; obecnie nie odnaleziony.

C. bacillaris (Leight.) Arnold - Gleba (zwłaszcza próchniczna) oraz nagie, murszejące pniaki na zrębach; rg. d.

7 stan. WR: dol. Cicha 600; Soblówka 670; pot. Radecki 700; g. Hutyrów 700; pot. Smerekówka Mała 700; pot. Śrubita 750. J: dol. Magurki 830.

C. bellidiflora (Ach.) Schaer. - Według Suzy (1951) rośnie na Babiej Górze; obecnie nie odszukany.

C. botrytes (Hagen.) Willd. - Czołowe powierzchnie murszejących pniaków iglastych, np. na zrębach; widne miejsca; rg. d. 
15 stan. WR: pot. Stasiowa 650; Soblówka 670; g. Hutyrów 700; pot. Danielka 700; pot. Smerekówka Wielka 700; Królowa 780; Smereków Wielki 800; g. Klin 850; g. Przysłop Mały 960; g. Kotarz 1110; g. Muńczoł 1125. P: pol. Buczynka 860; Śmierdzący Potok 1025. J: m. g. Jałowiec a g. Lachów Groń 950.

C. f. brevis (Sandst.) Sandst. - Żwirkowa, lekko wapnista gleba na nieużytkach; pg.

2 stan. J: pot. Surmiaków 550; dol. Bystrej 620.

C. caespiticia (Pers.) Flk. - Gliniasta gleba na skarpach dróg leśnych lub na stromych zboczach; miejsca nieco zacienione; zwykle w stanie płonnym; gatunek znacznie częstszy, ale początkowo nie wyróżniany; rg. d.

2 stan. WR: dol. Danielki 650. J: dol. Magurki 770.

C. cenotea (Ach.) Schaer. - Czołowe powierzchnie murszejących pniaków, leżące kłody, kora drzew iglastych u nasady pni; pg., rg. d., rg. g.

41 stan. WR: Stańcówka 640; Misiorka 700; Szczytkówka 735; Płaskonków 650; dol. Danielki 650; dol. Radeckiego 799; g. Muńczoł 1100; pot. Stasiowa 650; dol. Smerekówki Wielkiej 700; Las Ku Zimnej Wodzie 800; Słonkówka 625; pol. Raztoki 700; blisko g. Plaskierówka 1020; Soblówka 670; pol. Kołyska 940; dol. Śrubita 750; gednarów Beskid 920; pot. Urwisko 700; g. Rycerzowa 1150; Królowa 780; g. Klin 850; g. Kikula 1100. P: H. Miziowa na Romance 1120; pol. Buczynka 835; pot. Sikorczany Potok 700,735 ; g. Rysianka 1300; g. Boracza 1160; g. Lipowska 1260, 1320; las m. H. Lipowską a H. Bieguńską 1280; dol. Nickuliny 670; Z Gawłowskiego 700; pot. Kościelec 750; g. Długi Groń 820. J: dol. Zasepnicy 550; dol. Czernej 580; Kowaliczki 600; Złabne 680; dol. Magurki 830; g. Babiarzówka 870; H. Kubalkowa 1000; powyżej dol. Koryciny 1000; g. Czerniawa Sucha 1005.

C. cervicornis (Ach.) Flot. $[=$ C. verticillata (Hoffm.) Schaer. $]$ - Gleba na nieużytkach, m. jałowcami, wśród wrzosów; pg., rg. d.

27 stan. WR: g. Ochodziła 880; g. Kiczorka 590; m. Krutakami i Tarlicznem 635; g. Klimasy 710; Młaki 700; Popręcinka 700; g. Sobczański Groń 730; Płaskonków 600, 650; pol. Gardasówka 830; Podścigłów 720; przys. Magura 770. P: g. Kiczora nad Przyłękowem 720; g. Grapa Żar 500, 550; m. Juszczyną a Małą Sopotnią 580; pot. Loraniec 480; g. Kiczora 800; g. Palenica 710; dol. Rokitniaka 600; pot. Z Gawłowkiego 710; g. Długi Groń 880. J: g. Lachów Groń nad Skawicą 550; g. Skupniówka 600; Roztoki 700; g. Janoszka 700; przeł. Klekociny 920.

C. chlorophaea (Flk. ex Spreng.) Spreng. - Gliniasto-piaszczysta gleba, humus, m. mchami, na omszałych skałach, niekiedy u nasady pni starych drzew; pg., rg. d., rg. g., kos.

121 stan. WR: g. Syberia 550; g. Ochodzita 820; m. Krutakami i Tarlicznem 635; g. Zabawa 740; g. Popręcina 785; Młaki 700; pot. Krążelka 510; Do Staroni 760; Staronie 760; Zwardoń-Stańcówka 650; Myto 675; Rycerka 515; g. Hutyrów 670, 740; Graniczne 785; g. Rachowiec 850; g. Łysica 550; pot. Rycerka 580, 600; Szczytkówka 750, 865; g. Sobański Groń 730; g. Jaworzyna 1020; g. Praszywka Duża 970, 1030, 1040; pol. Wyrobniówka 925; g. Muńczoł 1125; Zawodzie 610; pot. Plaskurówka 680; Magura 820; pot. Stasiowa 560; pol. Bułkowa 760; Rycerki 655; Pętkówka 650; dol. Danielki 790; g. Wiertalówka 895, 1040; pol. Joneczkowe Rycerki 715; Raztoki 700; pol. Masarka 720; g. Będoszka Wielka 1100, 1130; leśniczówka Pod Raczą 715; las Na Kołysce 1000; m. górami Wielka Racza i Upłaz 1065; g. Rycerzowa Wielka 1195, 1205; pot. Urwisko 715; Hutyrowa 700; dol. Śrubita 750; rez. Śrubita 990; pol. Głowa 925; Królowa 780; g. Bednarów Beskid 940; las Orzeł 1030; g. Mała Racza 1070, 1135. P: g. Kiczora nad Przyłękowem 720; g. Grapa Żar 550; pot. Loraniec 480; g. Kiczora 800; pot. Bystra 585; g. Kotarnica 835; g. Palenica 685; Solany 445; las Tajch 750; przel. Przysłop 860; pot. Fułatów 520; H. Miziowa na Romance 1125; g. Malarka 1050; H. Majerkowa 1075; pot. Suchy 630; Żabnicka Rzeka 600; g. Prusów 965; g. Jodłowcowa 1100; pot. Studziański 660; Sopotnia Wielka 750; dol. Solarzówki 495; H. Łyśniowska 1090, 1190; H. Pawlusia 1170; pol. Szczyrbowe Młaki 910; Sucha Góra 750, 1000; H. Cudzichowa 1250; g. Pilsko 1400; rez. Rysianka 1140; dol. Boraczej 1025; H. Bieguńska 1150; H. Bacmańska 1125; las m. H. Lipowską a H. Bacmańską 1280; m. Śmierdzącym Potokiem a Zająców Potokiem 1055; pot. Połom 780; pot. Z Gawłowskiego 700; pot. Potok Jakubowski 645; g. Bucioryska 760; pol. Kotrysia Polana 720; g. 
Długi Groń 880; dol. Z Głębokiego 630; g. Kubiesówka 780; Polany Pod Soblówką 900. BG: Cyl 1485; Kościółki 1560. J: dol. Kalinki 540; g. Gawronowa 550; g. Grzechynia 550; pot. Surmiaków 550; przys. Podksięże 600; g. Ostra Górka 610; m. Korbielowem a Przyborówką 630; Roztoki 650; g. Skupniówka 650; g. Surzyny 670; Smeraki 700; Figury 700; dol. Magurki 750; przel. Klekociny 890; poniżej H. Kamińskiego 980; g. Jałowiec 1100; g. Mędralowa 1150.

C. coccifera (L.) Willd. - Gleba wśród jałowców; pg., rg. d. 3 stan. WR: g. Hutyrów 740; Szczotka 870. P: pot. Loraniec 480.

C. coniocraea (Flk.) Spreng. - Murszejące drewno (butwiejące kłody, pniaki, dachy szop i szałasów), również na korze starych omszałych drzew (bliżej nasady pni) lub między naziemnymi mchami, na nieużytkach, wśród borówek, jałowców; pg., rg. d., rg. g.

144 stan. WR: g. Kiczorka 780; pot. Czadeczka 510, 560, 610; m. przysiółkami Krutaki i Tarliczne 635; pol. Babczonka 620; g. Sołowy Wierch 840; pot. Krążelka 510; rez. Butorza 620; g. Biernatka 720; Stańcówka 640; g. Rachowiec 800; g. Hutyrów 740; g. Kłokocz 730; pot. Rycerka 580; Szczytkówka 750; g. Sobański Groń 730; dol. Danielki 700, 725; g. Praszywka Duża 970; pol. Wyrobniówka 925; g. Muńczoł 990, 1125; Kiełbasówka 700; Magura 850; pot. Stasiowa 650; pol. Bułkowa 760; g. Praszywka Mała 840; g. Kotarz 1110; Las Ku Zimnej Wodzie 800; pot. Butorzy 680; pot. Pętkówka 715; g. Wiertalówka 1040; pol. Raztoki 700; g. Przysłop Mały 960; pol. Skrzadnita 1105; m. pol. Raztoki a g. Pleskierówka 1000; las Na Kołysce 1000; g. Mała Racza 815; g. Rycerzowa 1205; g. Rycerzowa Wielka 1100, 1195; pot. Urwisko 705; g. Upłaz 1020; rez. Śrubita 990; m. polanami Majcherowa i Pietrówka 1120; pol. Głowa 815; Królowa 780; g. Bednarów Beskid 910, 1000; g. Klin 850; dol. Śrubita 975; las Orzeł 930; 1030. P: g. Grojec k. Żywca 610; Lachowe Młaki 885; g. Kotarnica 920; las Tajch 750; H. Miziowa na Romance 1075; Uszczawne 725; dol. W Kotarnicy 735; Latynka 1000; dol. Do Jodłowcowej 775; pol. Na Boruć 890; g. Romanka 1355; H. Wieprzska 1040; dol. Solarzówki 495; rez. Rysianka 900, 1110; g. Jodłowcowa 1100; H. Szczawina 1060; pot. Sikorczany Potok 700; Knoski 670; g. Rysianka 1300, 1320; g. Pilsko 1320, 1360, 1375; g. Palenica 1320; g. Szczawinka 1315; g. Boraczy Wierch 1160; H. Bacmańska 1125; H. Bieguńska 1150; g. Lipowska 1260, 1310, 1320; H. Lipowska 1100, 1250; przeł. Glinne 910; g. Magurka koło Trzech Kopców 1145; m. H. Lipowską a H. Bieguńską 1280; dol. Z Wideł 950; Śmierdzący Potok 950, 1010; Zająców Potok 1090; dol. Nickuliny 670; g. Prusów 1000; Jakubowski Potok 605, 680; g. Bucioryska 760; dol. Stara Piła 850; pot. Kościelec 695, 760; g. Okrągła 925; Jastrzębie 720; dol. Straceńca 695, 870, 910; g. Długi Groń 880; pol. Krawcula 1000. J: g. Sumerówka 565; Drwalówka 690; dol. Grzechynki 550; g. Kamienna 700; g. Ostra Górka 600; pot. Czerna 580; k. g. Witkówka 475; g. Magurka 800, 870; g. Skupniówka 650; g. Kwakowa 670; Siwcówka 600; pot. Stracony Potok 600; g. Urwisko 620; m. g. Jałowiec a g. Buciorys 775; Opaczne 900; Złabne 680; g. Jałowiec 950, 1030; pot. Kolędówka 650; las Czerniawa 940; g. Czerniawa Sucha 1000; pot. Opaczny 650; dol. Bystrej 590; Barankowa 800; dol. Magurki 830; H. Kamińskiego 1050; przel. Klekociny 890; dol. Głucha 680; g. Mędralowa 850; Pindelówka 1000; przeł. Jałowiecka 1017.

C. conista A. Evans - Gliniasta gleba oraz omszałe pnie starych drzew (głównie buki) i omszałe skały piaskowcowe; rg. d.

4 stan. WR: przys. Lastoczka 675; pol. Janówka 840; g. Będoszka Wielka 1130. P: g. Krzyżowa 720.

C. cornuta (L.) Hoffm. - Gleba między trawami oraz czoła murszejących pniaków; rg. d., kos.

5 stan. WR: g. Praszywka Mała 850; Soblówka 670; dol. Śrubita 760; przys. Królowa 780. BG: Diablak 1725 .

C. cyanipes (Sommerf.) Nyl. - Według SuZY (1951) rośnie na Babiej Górze. Obecnie nie stwierdzony.

C. deformis (L.) Hoffm. - Gleba; rg. d.

3 stan. P: dol. Wielkiej Sopotni 880. J: g. Sumerówka 565; g. Czerniawa Sucha 1005.

C. digitata (L.) Hoffm. - Butwiejące pniaki, u nasady pni drzew iglastych, rzadziej liściastych, niekiedy na glebie, gałęziach kosodrzewiny, na obumierających mchach naziemnych i naskalnych; przeważnie miejsca cieniste; pg., rg. d., rg. g., kos. 
118 stan. WR: pot. Czadeczka 510; pol. Babczonka 620; g. Kiczorki 800; Misiorka 700; dol. Radeckiego 700; dol. Danielki 725; pot. Stasiowa 710; pot. Plaskurówka 760; g. Kotarz 1110; pot. Pętkówka 740; g. Wiertalówka 1040; pol. Skrzadnita 1105; pol. Kołyska 920, 1000; pot. Racza 770; pot. Mała Jaworzyna 775; g. Rycerzowa 1205; g. Rycerzowa Wielka 1205; pot. Urwisko 705, 750; pol. Kapotkula 720; rez. Śrubita 990; g. Wielka Racza 1210; rez. Oszus 1085; Królowa 780; pol. Szkórki 930; g. Bednarów Beskid 950; g. Klin 850; las. Orzeł 960, 1020; g. Kikula 1100. P: dol. Kajdasówki 740; pol. Lachowe Młaki 910; dol. Cięcinki 700; dol. Sopotni Małej 700; H. Miziowa na Romance 1075, 1120; dol. poniżej Uszczawnego 670; dol. W Kotarnicy 735, 820; pol. Latynka 1000; dol. Do Jodłowcowej 775; g. Kotarnica 1070; g. Romanka 1335, 1350, 1260; H. Wieprzska 1040, 1180; g. Skałka 1140; H. Szczawina 1060; pot. Boracza 700; H. Łyśniowska 1190; g. Rysianka 1320; rez. Rysianka 1140, 1200; g. Pilsko 1320, 1350, 1360, 1400, 1420, 1425; las poniżej H. Mędralowej 1290; źródła Glinnej 1300; g. Palenica 1320; g. Szczawinka 1300, 1315; H. Cebulowa 1225; Turniczka 1380; g. Boraczy Wierch 1160; H. Bacmańska 1125; H. Bieguńska 1150; g. Lipowska 1100, 1260, 1310, 1320; przeł. Glinne 910; g. Magurka k. Trzech Kopców 1080, 1145; m. H. Lipowską a H. Bieguńską 1280; H. Rysianka 1150; H. Motykowa 1050; Śmierdzący Potok 750, 950; Zająców Potok 1090; dol. Nickuliny 670; Złotnice 925; pot. Z Gawłowskiego 685; g. Wilczy Groń 940; dol. Stara Piła 900; pot. Kościelec 750; pot. Jakubowski Potok 605; pol. Krawcula 1000, 1035; g. Krawców Wierch 1060. BG: las powyżej H. Czarnej 1200; las m. Markowymi Szczawinami a przeł. Brona 1255, 1310; m. przeł. Brona a Kościółkami 1450, 1490; las poniżej Akademickiej Perci 1300; pot. Kiczorka 1360; H. Kralowa 1120. J: m. g. Janoszka i g. Kiczora 500; dol. Zasepnicy 550; dol. Grzechynki 550; pot. Surmiaków 580; Siwcówka 600; Roztoki 650, 700; dol. Głucha 680; g. Magurka 800,870; g. Babiarzówka 870; przeł. Klekociny 890; Opaczne 950; m. g. Jałowiec a g. Lachów Groń 950; las Czerniawa 980; g. Czerniawa Sucha 1000; H. Kubalkowa 1000.

\section{C. fimbriata (L.) Fr. [= C. major (Hagen) Sandst., C. minor (Hagen) Vain.]}

\section{- Gliniasta gleba między darniami mchów, rzadziej murszejące pniaki lub omszałe} głazy i skałki piaskowcowe; pg., rg. d., rg. g.

97 stan. WR: g. Kiczorka 780; Wierch Czadeczka 680; m. Krutakami i Tarlicznem 635; pot. Czadeczka 510; g. Popręcina 785; pot. Krążelka 540; Do Staroni 760; g. Biernatka 720; Kiczora 610; g. Klimasy 710; g. Skalanka 785; g. Kłokocz 730; g. Hutyrów 650, 700; pot. Rycerka 580; pol. Jaworskie 610; dol. Danielki 700, 790; dol. Radeckiego 700; Zawodzie 610; Smereków Mały 625, 700; Podścigłów 700; Magura 850; pot. Stasiowa 650; dol. Smerekówka Wielka 700; Rycerki 620; g. Będoszka Wielka 1100; g. Pleskierówka 1000; Ciapków 700; Smereków Wielki 750; Soblówka 670; pot. Racza 835; g. Upłaz 1030; H. Przysłop 960; m. polanami Majcherowa i Pietrówka 1120; Królowa 780. P: leśniczówka Janikówka 415: g. Kiczora nad Przyłękowem 720; pot. Loraniec 460; pol. Lachowe Młaki 885; g. Juszczynka 880; dol. Kajdasówki 750; dol. Cięcinki 700; pot. Fułatów 520; pol. Na Boruć 890; pol. Kosarzyska 620; dol. poniżej Uszczawnego 800; g. Pilsko 1375; H. Cudzichowa 1260; H. Bieguńska 1150; g. Magurka k. Trzech Kopców 1145; Sucha Góra 750; pol. Gruszkowa 820; dol. Nickuliny 680; Śmierdzący Potok 950; Zająców Potok 1055; Jakubowski Potok 645; Sułki 660; Złotnice 925; Jastrzębie 720; pol. Kotrysia Polana 720; g. Długi Groń 820; g. Kotelnica 750. BG: las poniżej Akademickiej Perci 1300. J: g. Gawronowa 580; g. Sumerówka 565; Drwalówka 690; g. Kamienna 700; g. Ostra Górka 610; dol. Czernej 430; g. Grzechynia 550; dol. Grzechynki 450; g. Skupniówka 650; g. Kwakowa 670; Pytel 550; Janiki 780; g. Magurka 870; g. Janoszka 700; dol. Kalinki 540; g. Kiczora 890; g. Lachów Groń nad Skawicą 630; Siwcówka 540; dol. Gołynki 520; Opaczne 900; Roztoki 700; Spikówka 650; Złabne 680; g. Jałowiec 950, 1040; pot. Surmiaków Potok 580; g. Czerniawa Sucha 1000; m. g. Jałowiec a g. Lachów Groń 950; Barankowa 800; Beskidek 1010; dol. Głucha 580; przeł. Jałowiecka 1017.

\section{C. foliacea (Huds.) Willd. - Gleba gliniasta na nieużytkach; pg.}

2 stan. P: pot. Loraniec 460, 480.

C. furcata (Huds.) Schrad. - Piaszczysta, gliniasta lub kamienista gleba (nieużytki, wrzosowiska, przydroża leśne), wyjątkowo murszejące pniaki; pg., rg. d., rg. g., kos.

97 stan. WR: g. Syberia 550; g. Ochodzita 820; pot. Czadeczka 560; g. Kiczorka 690, 785; m. przysiółkami Krutaki i Tarliczne 635; g. Zabawa 760; g. Popręcina 785; Rycerka 560; Misiorka 700; g. Skalanka 785; g. 
Hutyrów 650, 740; g. Kłokocz 730; g. Burów Groń 685; pol. Pod Szczytkówką 750; g. Sobański Groń 730; Płaskonków 600, 650; dol. Danielki 725; dol. Radeckiego 700; g. Jaworzyna 1020; g. Praszywka Duża 1040; dol. Cichego 625; Podścigłów 720; Magura 850; g. Praszywka Mała 850; Młada Hora 940; dol. Smerekówki Wielkiej 700; U Jurzycowej 670; m. górami Wiertalówka i Kotarz 975; Raztoki 700; Pod Raczą 715; g. Będoszka Wielka 1130; Soblówka 670; pot. Racza 770, 835; Hutyrowa 700; pol. Majów 825; pol. Głowa 925; Królowa 780; g. Klin 800; g. Kikula 1100. P: Przyłęków 550; g. Kiczora nad Przyłękowem 720; g. Grapa Żar 500, 600; g. Groń nad Przyłękowem 700; m Juszczyną a Małą Sopotnią 580; g. Przypór 820; pot. Bystra 585; g. Kotarnica 810; dol. Cięcinki 700; pot. Fułatów 520; g. Palenica 710; H. Miziowa na Romance 1120; Sucha Góra 750, 1000; dol. Kosarzyska 620; H. Motykowa 1050; Śmierdzący Potok 950; Dziaski 735; g. Pilsko 1450; pot. Połom 780; g. Prusów 965; g. Bucioryska 760; pot. Z Gawłowskiego 655; g. Kiczora nad Ujsołami 700, 780; Kotrysia Polana 720; g. Długi Groń 820; g. Kubiesówka 780. BG: Akademicka Perć 1555. J: poniżej g. Czerniańska 425; g. Sumerówka 565; pot. Czerna 500; Drwalówka 690; g. Ostra Górka 600; g. Grzechynia 550; g. Skupniówka 650; Pytel 550; Janiki 780; m. g. Witkówką a Kudyjówką 500; g. Urwisko 610; dol. Kalinki 700; g. Lachów Groń nad Skawicą 630; Figury 810; Kolędówka 840; Roztoki 700; pot. Surmiaków Potok 580; dol. Magurki 750; Podjałowiec 950; dol. Głuchej 600, 700; H. Kamińskiego 1118.

C. glauca Flk. - Gliniasto-piaszczysta gleba; rg. d.

3 stan. WR: g. Kiczorka 780; g. Oźna 930. J: g. Czerniańska 550.

C. gracilis (L.) Willd. - Gliniasta lub kamienista gleba, rzadko murszejące pniaki; pg., rg. d, kos.

21 stan. WR: Popręcinka 700; g. Klimasy 710; Płaskonków 650; pot. Smerekówka Wielka 700; pol. Joneczkowe Rycerki 715; Szczytkówka 335; Królowa 780; g. Kotarz 1110; H. Mała Racza 1135. P: g. Grapa Żar 500; g. Kiczora 700; pot. Z Gawłowskiego 720; g. Jastrzębica 750; g. Bucioryska 795; Szeroki Kamieniec 900; g. Okrągła 950; g. Prusów 1000; Śmierdzący Potok 1055; g. Pilsko 1450. J: g. Jałowiec 870; m. g. Jałowiec a g. Lachów Groń 950.

C. macilenta Hoffm. - Murszejące pniaki, rzadziej kora żywych drzew albo podłoże skalne; rg. d., rg. g.

21 stan. WR: pot. Stasiowa 650; Płaskonków 650; Soblówka 670; pot. Radecki 700; pot. Danielka 700; pot. Plaskurówka 710; pot. Urwisko 780; g. Praszywka Mała 840; Raztoki 1020; g. Rycerzowa Wielka 1205. P: g. Długi Groń 850; g. Pilsko 1360. J: dol. Gołyńki 520; dol. Grzechynki 550; Siwcówka 590; g. Surzyny 670; Kolędówka 810; dol. Magurki 880; m. g. Jałowiec a g. Lachów Groń 950; powyżej dol. Korycina 1000.

C. macroceras (Del.) Hav. [ = C. elongata auct.] - Torfiasta gleba wśród kosodrzewiny i Empetrum nigrum; kos.

16 stan. P: g. Pilsko 1400, 1450, 1535. BG: Cyl 1485; Główniak 1570; powyżej przeł. Brona 1450; Kościółki 1500, 1600; Akademicka Perć 1525, 1555, 1570; m. Kościółkami a Diablakiem 1625; Diablak 1600, 1610, $1650,1725$.

C. macrophylla (Schaer.) Stenh. [ $=$ C. alpicola (Flot.) Vain.] - Według SuZY (1951) rośnie na Babiej Górze; obecnie nie potwierdzony.

C. merochlorophaea Asahina - Gliniasta lub kamienista gleba, często wśród mchów; pg., rg. d.

3 stan. WR: g. Łysica 550. P: g. Grapa Żar 500; pol. Alacowa 925.

C. ochrochlora Flk. - Murszejące i butwiejące drewno (powalone pnie, kłody, pniaki), niekiedy u nasady pni żywych, omszałych drzew; rg. d., rg. g.

26 stan. WR: pot. Rycerka 580; Soblówka 670; pol. Masarka 720; pol. Bułkowa 785; pot. Plaskurówka 800; pol. Cerla 1000; Raztoki 1020; pol. Skrzadnita 1105. P: Jakubowski Potok 645; Sucha Góra 750; pol. Koziorka 800; przeł. Glinne 910; Złotnice 925; pol. Krawcula 1035; Śmierdzący Potok 1055; g. Trzy Kopce 1100; H. Rysianka 1200; H. Cebulowa 1225, 1280; g. Lipowska 1280, 1320. J: dol. Gołyńki 520; dol. Zasepnicy 550; dol. Opacznego 800; m. g. Jałowiec a g. Lachów Groń 950; g. Czerniawa Sucha 1000. 
C. peziziformis (With.) Laundon [= C. capitata (Michx.) Spreng., C. leptophylla (Ach.) Flk.] Gliniasta gleba między kamieńcami nadrzecznymi; suche i widne miejsca; gatunek zapewne częstszy, lecz przeoczany; pg.

1 stan. J: Koszarawa 560.

C. phyllophora Hoffm. [= C. degenerans (Flk.) Spreng.] - Próchniczna gleba, np. w sztucznie sadzonych lasach świerkowych; rg. d.

5 stan. P: Zapolanka 1000. J: pot. Surmiaków Potok 580; g. Urwisko 610; g. Lachów Groń nad Skawicą 630; pol. Skalaniec 850 .

C. pleurota (Flk.) Schaer. - Torfiasta gleba wśród mchów, ziemia gliniasta na nieużytkach, na omszałych głazach piaskowcowych; pg., rg. d., rg .g., kos.

58 stan. WR: g. Syberia 550; Rycerka 585; Tomusie 600; Krutaki 635; Popręcinka 700; g. Zabawa 740; Młaki 745; g. Klimasy 710; Stawonie 760; g. Kiczorka 700, 785; g. Popręcina 785; Podścigłów 720; g. Łysica 550; pol. Pawliki 775; pot. Plaskurówka 735; Graniczne 785; Magura 820; pol. Gardasówka 830; Szczytkówka 865; g. Oźna 930; g. Praszywka Duża 1030; g. Rycerzowa 1140. P: g. Grapa Żar 500; Przyłęków 550; g. Przypór 820; pot. Kajdasówka 685; pot. Fułatów 460; g. Bucioryska 795; g. Kiczora 800; g. Juszczynka 880; pol. Na Boruć 905; g. Sucha Góra 1000; g. Malarka 1055; g. Lipowska 1320; g. Boraczy Wierch 1230; g. Pilsko 1400, 1425, 1445, 1450, 1465, 1490. BG: Cyl 1485; Kępa 1520; przeł. Brona 1410; m. Kościółkami a przeł. Brona 1490; Główniak 1570; Kościółki 1560; Akademicka Perć 1570; Diablak 1610, 1680, 1710, 1725. J: g. Czerniańska 550; przys. Podjałowiec 950.

C. pocillum (Ach.) Grognot - Gliniasto-wapnista gleba, omszałe skały wapniste albo omszałe pnie starych drzew liściastych (stare buki); pg., rg. d.

10 stan. WR: Rycerka 515; Głębokie 610; g. Burów Groń 690; Pietraszyna 840. P: pot. Suseński 480; pot. Głębokie 580; pot. Studziański 660; las pod H. Lipowską 1100; g. Romanka 1120. J: Koszarawa (wylot pot. Bystra) 590 .

C. polycarpoides Nyl. [ = C. subcariosa auct.] - Gliniasta gleba na nieużytkach i innych suchych a widnych miejscach; pg., rg. d.

4 stan. WR: g. Syberia 550; Magura 820. P: g. Grapa Żar 500. J: dol. Grzechynki 575.

C. polydactyla (Flk.) Spreng. - Butwiejące kłody (powalone i butwiejące świerki); rg. g.

1 stan. P: g. Romanka 1350.

C. pyxidata (L.) Hoffm. - Piaszczysta i gliniasta gleba, np. między jałowcami, omszałe skały i głazy piaskowcowe, niekiedy u nasady pni starych drzew; pg., rg. d. 25 stan. WR: Rycerka 515; g. Syberia 550; Młaki 700; g. Łysica 550; pot. Smerekówka Mała 700; Podścigłów 770; Kołyska 1010; g. Rycerzowa 1100; pol. Skrzadnita 1105; g. Muńczoł 1125. P: pot. Loraniec 480; pot. Suseński 480; pot. Z Gawłowskiego 650, 700; pot. W Kotarnicy 735; Sucha Góra 750; Na Piętrze 835; H. Jodłowcowa 1200; g. Pilsko 1360. BG: Suchy Potok 1365; Diablak 1710, 1725. J: dol. Grzechynki 450; g. Jałowiec 1110.

C. ramulosa (With.) Laundon $[=C$. pityrea (Flk.) Fr. $]$ - Gliniasta gleba; miejsca widne; rg. d.

1 stan. P: g. Okrągła 830.

C. rangiformis Hoffm. - Gliniasta i kamienista gleba na nieużytkach; pg., rg. d. 13 stan. WR: g. Syberia 550; Rycerka 560; g. Sobański Groń 730; Magura 850. P: pot. Fułatów 430; pot. Loraniec 460; pot. Solarzówki 670; Basiówka 700; g. Kiczora nad Ujsołami 780. J: dol. Grzechynki 450; dol. Czernej 500; dol. Kalinki 520; Figury 700.

C. squamosa Hoffm. - Gleba oraz nasadowe części pni starych drzew (świerki, jodły, rzadziej buki, jawory), niekiedy murszejące pniaki; pg., rg. d., rg. g. 43 stan. WR: m. Krutakami i Tarlicznem 635; Płaskonków 650; pot. Plaskurówka 760; pol. Cerla 1045; g. Mała Racza 815; rez. Śrubita 780, 990; g. Wielka Racza 1210; g. Rycerzowa Wielka 1205; rez. Oszus 1075, 1085; g. Klin 850; las Orzeł 960. P: pot. Loraniec 520; pot. Suchy 630; H. Wieprzska 1175; g. Pilsko 1350, 
1400, 1420, 1450; las poniżej H. Mędralowej 1290; pot. Glinna 1220, 1260, 1305; g. Szczawinka 1200; g. Rysianka 1300; H. Bacmańska 1125; H. Bieguńska 1150; g. Lipowska 1260, 1310; dol. Z Wideł 950; m. potokami Śmierdzący Potok a Zająców Potok 1090; Zająców Potok 820; pot. Z Gawłowskiego 710; dol. Straceńca 900. BG: las poniżej Sokolicy 1230; las poniżej Akademickiej Perci 1300. J: dol. Bystrej 680; Drwalówka 620; Figury 700; poniżej Podjałowca 800; g. Babiarzówka 870; g. Czerniawa Sucha 1000.

C. subsquamosa (Nyl. ex Leight.) Cromb. - Torfiasta gleba; kos.

7 stan. BG: Cyl 1485; Główniak 1770; powyżej przeł. Brona 1450; Kościółki 1560; Akademicka Perć 1570; Diablak 1600, 1710.

C. subulata (L.) Werner ex Wigg. $[=C$. cornutoradiata (Vain.) Zopf $]$ - Gliniasta lub kamienista gleba wśród traw i borówek, rzadziej butwiejące drewno; pg., rg. d., rg. g., kos.

75 stan. WR: g. Kiczorka 750, 785; pot. Czadeczka 610; m. Krutakami i Tarlicznem 635; g. Popręcina 785; g. Sobczańska Grapa 740; pot. Krążelka 510; Do Staroni 760; Tomusie 600; g. Biernatka 720; Staronie 760; g. Skalanka 785; g. Kłokocz 730; g. Łysica 550; g. Sobczański Groń 730; Obłaz 830; pol. Na Praszywce 950; Podścigłów 720; pol. Bułkowa 785; g. Praszywka Mała 850; pot. Plaskurówka 735; pot. Pętkówka 715; g. Wiertalówka 895, 975, 1040; pol. Joneczkowe Rycerki 715; Smereków Wielki 750; przys. Raztoki 700; pol. Kołyska 1010; pot. Racza 770; g. Rycerzowa 1205; dol. Śrubita 760; H. Mała Racza 1135; Królowa 780. P: g. Kiczora nad Przyłękowem 720; g. Grapa ]ar 500; pot. Loraniec 460; g. Kiczora 835; H. Durajka 835; pot. Bystra 585; g. Magura 850; dol. Kajdasówki 750; pot. Fułatów 430, 520; dol. Cięcinki 700; las Tajch 750; H. Miziowa na Romance 1120; pot. Suchy 630; g. Prusów 965; dol. Sopotni Wielkiej 750; Sucha Góra 800; g. Pilsko 1445, 1460; pot. Z Gawłowskiego 760; Jakubowski Potok 645; g. Bucioryska 760; pot. Głęboki 640; Polany Pod Soblówką 900. BG: pot. Kiczorka 1130. J: dol. Czernej 430; dol. Grzechynki 450; Chudziakówka 500; g. Sumerówka 570; Koszarawa 590; g. Urwisko 620; g. Surzyny 670; Drwalówka 690; dol. Głucha 690; Roztoki 700; g. Janoszka 700; g. Witkówka 740; Janiki 750; g. Kiczora 850; Opaczne 950; H. Kubalkowa 1090.

C. sulphurina (Michx.) Fr. [= C. gonecha (Ach.) Asahina] - Gleba, często wśród piargów i między kosodrzewiną; kos.

7 stan. P: g. Pilsko 1450, 1480, 1490. BG: Cyl 1485; Kępa 1520; Kościółki 1560, 1600.

C. symphycarpa (Flk.) Fr. $[=C$. hungarica (Arnold) Vain. $]$ - Wapnista gleba nad potokami; pg.

2 stan. J: pot. Surmiaków Potok 550; Roztoki 680.

C. turgida Hoffm. - Gliniasta gleba między jałowcami, wśród traw, nieużytki; pg., rg. d.

21 stan. WR: g. Kiczorka 700; g. Popręcina 785; g. Rachowiec 700; g. Hutyrów 650; g. Sobański Groń 730; Płaskonków 600; pol. Juroszkowa 850. P: g. Groń nad Przyłękowem 720; g. Kiczora nad Przyłękowem 720; g. Grapa Żar 550; pot. Loraniec 480; pol. Lachowe Młaki 910; Zapolanka 900; g. Kiczora nad Ujsołami 780. J: g. Lachów Groń nad Skawicą 630; g. Skupniówka 650; Figury 700; dol. Opacznego 750; dol. Magurki 750; g. Magurka 870; Podjałowiec 970.

C. uncialis (L.) Web. ex Wigg. - Humusowa i kamienista gleba, np. wrzosowiska; rg. d., kos.

2 stan. WR: g. Burów Groń 685. P: g. Pilsko 1425.

Clauzadea monticola (Schaer.) Hafellner \& Bellem. [ = Lecidea monticola Schaer., L. ochracea Hepp ex Koerb.] - Wapniste piaskowce, zaprawa murarska; zwykle miejsca cieniste, ale suche; pg., rg. d.

7 stan. WR: Rycerka 515; pot. Butorza 590; m. Zwardoniem a Stańcówką 650; pot. Urwisko 700. P: pot. Suseński 480; g. Abrahamów 810. J: pot. Dejówka 520.

Cliostomum corrugatum (Ach.) Fr. [= Catillaria graniformis (Hagen) Vain.] - Według Steina (1872) rośnie na Babiej Górze; obecnie nie stwierdzony. 
C. griffithii (Sm.) Coppins $[=$ Catillaria griffithii $(\mathrm{Sm}$.) Malme $]-$ Kora drzew iglastych, głównie stare jodły, zwykle razem z Arthonia mediella; rg. d.

2 stan. WR: pot. Urwisko 760. P: Zająców Potok 1000.

Collema auriforme (With.) Coppins \& Laundon [ $=$ C. auriculatum Hoffm.] - Wapniste łupki, między mchami; miejsca raczej cieniste; rg. d.

1 stan. WR: Las Ku Zimnej Wodzie 800.

C. dichotomum (With.) Coppins \& Laundon $[=C$. fluviatile (Huds.) Steud, Leptogium cataclystum (Koerb.) Harm.] - Nieustannie spryskiwane czystą wodą progi skał piaskowcowych w bardzo stromych i cienistych łożyskach potoczków, zwykle blisko źródeł; rg. d.

1 stan. J: N stok g. Jałowiec 850.

C. flaccidum (Ach.) Ach. - Wilgotne głazy piaskowcowe wystające z wody na brzegach potoków górskich; pg., rg. d.

6 stan. P: Żabnicka Rzeka 590. J: dol. Bystrej 590, 680; pot. Glucha 600; dol. Grzechynki 450; dol. Wilkówki 475.

C. fuscovirens (With.) Laundon [=C. tuniforme (Ach.) Ach.] - Wapienne i wapniste skałki; miejsca widne i suche albo umiarkowanie cieniste; pg.

1 stan. P: Sporysz 420.

C. nigrescens (Huds.) DC. - Omszała kora starych buków, zwykle u nasady pni; rg. d.

1 stan. BG: Sulowa Cyrla 840.

C. tenax (Sw.) Ach. em. Degel. - Gliniasto-wapnista gleba; miejsca nieco wilgotne; pg., rg. d.

6 stan. WR: Ochodzita 760; pot. U Jurzycowej 680; Las Ku Zimnej Wodzie 800. P: Sporysz 420; g. Grojec k. Żywca 610. J: dol. Gołyńki 520.

C. undulatum Laurer ex Flot. - Wapienie w miejscach nieco cienistych; pg. 1 stan. P: Sporysz 420.

Cybebe gracilenta (Ach.) Tibell [= Coniocybe gracilenta Ach.] - Rozkładające się drewno (wypróchniałe pnie starych drzew, wiatrołomy); miejsca cieniste; rg. d, rg. g.

4 stan. WR: rez. Oszus 1000. P: rez. Rysianka 970. BG: las m. Markowymi Szczawinami a przeł. Brona 1310. J: dol. Bystrej (poniżej pol. Polanice) 590.

Cystocoleus ebeneus (Dillw.) Thwaites $[=C$. niger (Huds.) Hariot, Coenogonium nigrum (Huds.) A. Zahlbr.] - Bezwapienne skały piaskowcowe; miejsca pionowe lub podwieszone, cieniste lecz suchsze; rg. d., rg. g., kos.

6 stan. P: Na Piętrze 835; g. Czarny Groń 900; g. Boraczy Wierch 1100; g. Romanka 1200; g. Szczawinka 1315. BG: Akademicka Perć 1525.

Dermatocarpon luridum (With.) Laundon $[=$ D. fluviatile $(\mathrm{Web}$.$) Th. Fr. ]$ - Głazy piaskowcowe opryskiwane wodą w łożyskach potoków górskich bliżej ich źródeł; miejsca bystre; kos.

1 stan. P: źródła pot. Glinna 1350.

D. miniatum (L.) Mann - Pionowe i suche skałki wapniste (gruboziarniste piaskowce); rg. d.

1 stan. P: g. Grojec k. Żywca 610.

Dibaeis baeomyces (L. fil.) Rambold \& Hertel [= Baeomyces roseus Pers.] - Gliniasta gleba (obok ścieżek, nieużytki, skarpy dróg); miejsca widne i suche; często płonne; pg., rg. d., rg. g. 
87 stan. WR: g. Syberia 550; g. Kiczorka 785; Wierch Czadeczka 680; m. Krutakami i Tarlicznem 635; g. Popręcina 785; Młaki 745; Tomusie 600; Staronie 760; Rycerka 520, 585; Głębokie 650; pot. Z Głębokiego 580; Szpaki 575; g. Klimasy 710; pot. Głęboki 700; g. Skalanka 785; g. Kłokocz 730; g. Hutyrów 740; g. Solański Groń 805; Szczytkówka 865; dol. Radeckiego 700; g. Praszywka Duża 1030; pol. Wyrobniówka 925; Podścigłów 700, 770; pol. Pawliki 775; dol. Smerekówka Wielka 700; pol. Raztoki 700, 750; H. Przysłop 750; pot. Racza 770; g. Rycerzowa 1160; H. Rycerzowa 1140. P: g. Grojec 500; Przyłęków 550; g. Grapa Żar 500; pot. Loraniec 480; g. Kiczora 800; g. Krzyżowa 720; g. Juszczynka 880; g. Kotarnica 810, 980; dol. Kajdasówki 750; pot. Fułatów 430; pod Uszczawnym 800; g. Malarka 1055; pol. Na Boruć 905; przys. Za Jurkową 880; Komery 575; g. Pilsko 1385; H. Redykalna 1140; g. Sucha Góra 930; Zapolanka 850; g. Bucioryska 765; pot. Z Gawłowskiego 645, 760; Potok Jakubowski 605; g. Kiczora nad Ujsołami 700; pot. Głęboki 580; Kotrysia Polana 720; g. Okrągła 850. J: dol. Czernej 430; m. Grzechynią a Skupniówką 450; dol. Zasepnicy 500; dol. Kalinki 520; Siwcówka 540; dol. Grzechynki 550; dol. Głucha 580; pot. Surmiaków Potok 600; g. Skupniówka 650; blisko Korbielowa 650; g. Janoszka 670; g. Surzyny 670; Roztoki 700; dol. Kalinki 700; dol. Magurki 770; Kijakowa 810; przys. Kolędówka 850; g. Kiczora 890; przeł. Klekociny 930; Opaczne 950; Podjałowiec 950; Pindelówka 1000; Beskidek 1010; H. Kamińskiego 1118.

Dimerella diluta (Pers.) Trevis. - Kora drzew liściastych rosnących w naturalnych lasach, rzadziej murszejące pniaki; rg. d.

10 stan. WR: g. Trojaki 615; pot. Danielka 700; las Orzeł 1030; rez. Oszus 1075. P: las Tejch 750; Zająców Potok 940; H. Lipowska 1100; rez. Rysianka 1025; H. Bieguńska 1150; H. Wieprzska 1160.

Diploschistes muscorum (Scop.) R. Sant. $[=$ D. bryophilus (Ehrh. ex Ach.) A. Zahlbr.] - Obumierające mchy naskalne, naziemne lub rosnące na pniach drzew (buki); pg., rg. d.

6 stan. WR: m. Rycerką a Rajczą 485; g. Łysina 550. P: pot. Loraniec 480; pot. Suchy 630; H. Bacmańska 1125. J: Roztoki 620.

D. scruposus (Schreb.) Norm. - Bezwapienne skały, głazy i kamienie piaskowcowe; miejsca suche i widne; pg., rg. d.

20 stan. WR: Pietraszyna 840; Rycerka 520; g. Burów Groń 690; g. Rycerzowa 1170. P: g. Grojec 610; pot. Suchy 630; g. Boraczy Wierch 1100; dol. W Ciemnym 1170; g. Skałka 1190. J: dol. Bystrej 600; Topory 700; g. Czerniańska 450; dol. Gołyńki 520; dol. Grzechynki 450; dol. Kalinki 540; g. Lachów Groń nad Skawicą 600; Roztoki 610; g. Skupniówka 600; pot. Surmiaków Potok 550; g. Kwakowa 670.

Diplotomma lutosum Massal. [ = Buellia lutosa (Massal.) Anzi] - Bezwapienne lub słabo wapniste piaskowce (gołoborza, kamyki na nieużytkach); miejsca suche i widne; pg., rg. d.

2 stan. WR; g. Łysica 550. P: Sporysz 420.

D. nivalis (Bagl. \& Carestia) Hafellner $[=$ B. margaritacea (Sommerf.) Lynge] - Wapniste piaskowce; miejsca suche i widne; pg.

1 stan. P: pot. Głębokie 580.

Eiglera flavida (Hepp) Hafellner [ = Lecanora flavida Hepp] - Bezwapienne lub słabo wapniste piaskowce, czasami nad brzegami potoków; miejsca suche i widne; rg. d.

3 stan. WR: Soblówka 670; pot. Urwisko 700. J: m. Grzechynią a Skupniówką 470.

Enterographa zonata (Koerb.) Kallsten in Torrente \& Egea [= Opegrapha zonata Koerb.] - Bezwapienne, pionowe i zacienione skały piaskowcowe (suche, rzadziej lekko wilgotne); pg., rg. d., rg. g.

10 stan. WR: Las Ku Zimnej Wodzie 800. P: g. Czarny Groń 900; pot. Boracza 1025; g. Solisko 1040; g. Boraczy Wierch 1100; g. Romanka 1200, 1225; g. Szczawinka 1315. J: dol. Grzechynki 450; g. Magurka 850. 
Evernia divaricata (L.) Ach. - Według SUZY (1951) rośnie na Babiej Górze; obecnie nie odszukany.

E. prunastri (L.) Ach. - Kora drzew liściastych tworzących lasy (buki. jawory, dęby) lub pojedynczo rosnących obok dróg, nad potokami, rzadko na drzewach iglastych; pg., rg. d.

33 stan. WR: pot. Krążelka 520; Wełniakówka 590; Piekło 620; g. Rachowiec 850; g. Łysica 570; Słonkówka 625, 750; Pętkówka 650; leśniczówka Pod Raczą 715; pot. Racza 755; pol. Bułkowa 760; g. Będoszka Wielka 1100; g. Rycerzowa 1120. P: leśniczówka Janikówka 415; Żabnicka Rzeka 600; Złatna 600, 610; Sułki 665; pot. Straceniec 695, 775; Placówka 710; Sucha Góra 750; pot. Stara Piła 780; pol. Koziorka 800; H. Łyśniowska 1090. J: dol. Zasepnicy 440; Pasierbiaki 520; Dolinka 620; dol. Cicha 700; dol. Koszarawy 800; przeł. Klekociny 890; H. Kamińskiego 1110.

\section{Flavocetraria cucullata (Bell.) Kdrnefelt \& Thell [= Cetraria cucullata (Bell.)} Ach.] - Gleba między mchami, borówkami i bażynami; kos.

14 stan. P: g. Pilsko 1445, 1470, 1500. BG: Cyl 1485; Kępa 1520; Główniak 1570; Akademicka Perć 1570; m. Kościółkami a Diablakiem 1625; Diablak 1600, 1690, 1700, 1710, 1725.

F. nivalis (L.) Kdrnefelt \& Thell [= Cetraria nivalis (L.) Ach.] - Gleba między mchami; kos.

6 stan. BG: Główniak 1570; Diablak 1660, 1665, 1700, 1710, 1725.

Flavoparmelia caperata $(\mathbf{L}$.$) Hale [=$ Parmelia caperata $($ L.) Ach.] - Kora drzew liściastych; pg., rg. d.

16 stan. WR: Rycerka Dolna 525; przys. Rycerki 645; leśniczówka Pod Raczą 715. P: leśniczówka Janikówka 415; Juszczyna 430; Przyłęków 475; Złatna 600; Żabnicka Rzeka 600. J: dol. Zasepnicy 460; Pasierbiaki 520; Skupniówka 525; pot. Surmiaków Potok 600; Szarleje 600; Łabędzie 620; Kobiele 650; g. Drwalowa 680.

\section{Fuscidea kochiana (Hepp) V. Wirth \& Vězda [= Lecidea kochiana Hepp]} - Bezwapienne skały piaskowcowe; miejsca suche i widne; kos.

7 stan. BG: Kępa 1520; Sokolica 1370; Kościółki 1510, 1580; Akademicka Perć 1525; Diablak 1660, 1710.

Graphis scripta (L.) Ach. - Kora drzew liściastych i iglastych; rg. d.

72 stan. WR: g. Trojaki 615; g. Muńczoł 1150; Podścigłów 700; Żebrakówka 800; Wir Danielek 910; dol. Przegibka 760; g. Przysłop Mały 960; pol. Skrzadnita 1105; pot. Racza 800; g. Wielka Racza 1180; pot. Mała Jaworzyna 775; g. Rycerzowa Wielka 1195; pot. Urwisko 730; H. Rycerzowa 1100; g. Majcherowa 950; dol. Śrubita 750, 975; rez. Śrubita 985, 990; g. Bednarów Beskid 950, 1000; rez. Oszus 1010, 1150; las Orzeł 980, 1030. P: las Tajch 750; H. Miziowa na Romance 1075; dol. W Kotarnicy 850; H. Wieprzska 1110; pol. Buczynka 860; pot. Boracza 700; pol. Szczyrbowe Młaki 910; H. Bacmańska 1125; H. Lipowska 1100; Zająców Potok 1000; H. Bieguńska 1150; g. Trzy Kopce 1160; rez. Rysianka 1130; Śmierdzący Potok 900, 950; pot. Z Gawłowskiego 770; Na Piętrze 835; Szeroki Kamieniec 800; dol. Stara Piła 825, 900; pot. Kościelec 680, 700; g. Okrągła 925; dol. Straceńca 695, 910; g. Długi Groń 840. BG: las poniżej H. Czarnej 1060. J: dol. Czernej 580; las Czerniawa 980; g. Czerniawa Sucha 1030; pot. Głucha 600; H. Kamińskiego 1050; Kępy 550; g. Kiczora 880; H. Kubalkowa 1000; dol. Magurki 750; g. Mędralowa 1150; pot. Opaczny 700; Pindelówka 1000; Podjałowiec 930; Podksięże 480; Roztoki 600, 650, 800; Siwcówka 600 ; pot. Stracony Potok 600.

Gyalecta flotowii Koerb. - Kora starych buków (najczęściej w jej spękaniach) rosnących w naturalnych lasach; rg. d.

9 stan. WR: rez. Śrubita 780, 985, 990; las Orzeł 980, 1030. P: rez. Rysianka 980, 1000, 1025, H. Wieprzska 1150. BG: las poniżej H. Czarnej 1040.

G. jenensis (Batsch.) A. Zahlbr. - Wapienie i wapniste piaskowce (skałki, głazy i kamienie); rg. d.

9 stan. WR: pot. Urwisko 700; Las Ku Zimnej Wodzie 800. P: Na Piętrze 835; g. Boraczy Wierch 1100; g. Skałka 1195. J: pot. Głucha 600; Matusy 520; Roztoki 620; pot. Surmiaków Potok 550. 
G. ulmi (Sw.) A. Zahlbr. - Kora starych buków rosnących w naturalnych lasach; rg. d.

1 stan. P: rez. Rysianka 1000.

Hymenelia ceracea (Arnold) Poelt \& Vězda [ = Aspicilia ceracea Arnold] - Bezwapienne piaskowce lub o nieznacznej zawartości węglanu wapnia (najczęściej na kamykach); miejsca suche, choć zwykle cieniste; rg. d., rg. g.

8 stan. WR: Zawodzie 610; Płaskonków 650; g. Klin 800; pot. Racza 835. P: Szeroki Kamieniec 790; H. Jodłowcowa 1250. J: dol. Zasepnicy 460; Matusy 520.

\section{Hypocenomyce caradocensis (Leight. ex Nyl.) P. James \& Schneid. - Kora} starych świerków i jodeł; rg. d, rg. g.

4 stan. (leg. U. BielCZYK). P: g. Romanka 1250; g. Szczawina 1250; g. Pilsko 1200; dol. Nickuliny 680.

H. scalaris (Ach.) Choisy [= Lecidea scalaris (Ach.) Ach. $]$ - Kora drzew iglastych, głównie u nasady pni, rzadziej murszejące drewno dachów szałasów); pg., rg. d. (dość często), rg. g. (rzadko).

45 stan. WR: g. Kiczórki 820; Wierch Czadeczka 680; g. Podgórka 770; Ogrody 690; pot. Czadeczka 680; pot. Krążelka 510; pol. Babczonka 620; g. Popręcina 785; g. Sobczakowa Grapa 765; pot. Czerna 610; Zwardoń 670; g. Kępa 490; pot. Butorzy 680; Rycerki 645; pot. Plaskurówka 750; Młada Hora 915; pot. Danielka 700, 725; g. Muńczoł 1100; pol. Raztoki 875; g. Beskid Wrzeszcz 860; g. Jaworzyna 850. P: H. Wieprzska 1110; las poniżej H. Bieguńskiej 1150; dol. Do Jodłowcowej 725; pot. Z Gawłowskiego 710; g. Romanka 1280; H. Cukiernicza Wyżnia 860; pol. Golcówka 765; pol. Buczynka 880; pot. Bystra 585; pot. Fułatów 520; Zapolanka 850. J: g. Babiarzówka 870; g. Drwalowa 600; g. Grzechynia 500; H. Kubalkowa 1000; g. Magurka 800, 870; g. Ostra Górka 600; Siwcówka 600; pot. Stracony Potok 600; Szczurkówka 840; dol. Zasepnicy 440; Zimna Woda 675.

H. sorophora (Vain.) P. James \& Poelt in Poelt \& Vězda [= Lecidea xanthococca subsp. sorophora Vain.] - Kora świerków, murszejace pniaki; rg. d., rg. g.

2 stan. P: g. Rysianka 1300; H. Rysianka 1180.

Hypogymnia bitteri (Lynge) Ahti $[=H$. obscurata auct. $]$ - Omszałe pnie starych świerków, rzadko buków; rg. d., rg. g.

3 stan. P: H. Pawlusia 1180; g. Rysianka 1245; g. Szczawinka 1260.

H. farinacea Zopf [ = H. bitteriana (A. Zahlbr.) Räs.] - Kora starych świerków, rzadziej jodeł, jaworów, gałęzi kosodrzewiny, martwe drewno (dachy szałasów); rg. d., rg. g., kos.

23 stan. WR: g. Popręcina 685; g. Bednarów Beskid 1050; rez. Oszus 1110. P: pol. Krawcula 1000; g. Krawców Wierch 1060; H. Wieprzska 1060, 1110; H. Redykalna 1060; Śmierdzący Potok 1090; H. Lipowska 1100; pol. Bartek 1150; g. Rysianka 1180; g. Lipowska 1260, 1310; las powyżej H. Mędralowej 1290, 1360; g. Szczawinka 1260. J: g. Magurka 870.

H. physodes (L.) Nyl. - Kora drzew iglastych i liściastych, martwe drewno; pg., rg. d., rg. g., kos.

228 stan. WR: Kasperki 670; pot. Sucha Nieledwianka 520; pot. Czadeczka 530, 545, 560; m. Krutakami i Tarlicznem 635; Zapasieki 660; pol. Babczonka 620; g. Popręcina 785; g. Syberia 550; pot. Czerna 610; Wierch Czadeczka 680; g. Zabawa 790; pot. Krążelka 510; g. Trojaki 615; rez. Butorza 620; g. Kiczora nad Mytem 800; g. Podgórka 770; przel. m. górami Popręcina i Kiczora 685; Zagajka 625; Rajcza 500; g. Rachowiec 800, 850; Zwardoń 720; Orawcowa 775; Misiorka 700; g. Beskid Wrzeszcz 860; g. Kokocz 730; g. Oźna 900; g. Sobański Groń 730; dol. Danielka 725; dol. Cicha 600; g. Jaworzyna 885, 930; pol. Na Praszywce 950; pol. Jaroszkowa 850; g. Muńczoł 1105, 1150; dol. Plaskurówki 700; pol. Bułkowa 760; g. Praszywka Mała 840; Rycerki 680; Pętkówka 650; pol. Żebrakówka 800; Kolonia 670; pot. Butorzy 680; pol. Cerla 1000; pot. Pętkówka 725; g. Wiertalówka 895, 1065; g. Przysłop Mały 960; pol. Ziajówka 850; pol. Skrzadnita 1105; leśniczówka Pod Raczą 715; g. Pleskierówka 1085; g. Będoszka Wielka 1100; las Solisko 650; pot. Racza 755; g. Mała Racza 815; pot. Mała Jaworzyna 775; g. Rycerzowa 1180; g. 
Rycerzowa Wielka 1195; pot. Urwisko 705; H. Rycerzowa 1100; g. Majcherowa 950; g. Upłaz 1050; rez. Śrubita 990; g. Wielka Racza 1200, 1210; rez. Oszus 1110; pol. Głowa 815; g. Bednarów Beskid 910, 1050; dol. Śrubita 975; las Orzeł 960, 1030; g. Jaworzyna k. Bugaja 1150. P: g. Grojec 610; g. Kępa 490; las Gajka 500; pot. Loraniec 520; Kolonia 550; las Uszczawne 910; przeł. Przysłop 860; dol. W Kotarnicy 850; powyżej Latynki 1000; g. Romanka 1360, 1365; pot. Romanka 750; Żabnicka Rzeka 600; m. Ciścem a Milówką 650; g. Prusów 1000, 1005; przeł. Przysłopy 750; g. Kotarnica 920; dol. Kajdasówki 860; H. Wieprzska 1160, 1110, 1175; g. Skałka 1140; dol. W Ciemnym 900; g. Jodłowcowa 1100; Milówki 700; dol. Buczynki 800; dol. Solarzówki 495; pol. Bartek 1150; pot. Syndzielny 690; Sikorczany Potok 700; pol. Koziorka 800; H. Łyśniowska 1190; leśniczówka Glinna 750; g. Rysianka 1180, 1300, 1320; g. Pilsko 1340, 1350, 1360, 1400, 1450, 1460, 1500; las poniżej H. Mędralowej 1290; H. Cudzichowa 1175; g. Palenica 1320; pol. Między Młaki 1200, 1225; H. Cukiernicza Wyżnia 860; Sucha Góra 750; g. Boraczy Wierch 1160, 1240; H. Bacmańska 1125; H. Bieguńska 1150; g. Lipowska 1100, 1260, 1310; g. Jaworzyna 1025; g. Magurka k. Trzech Kopców 1080, 1145; pol. Sucha Góra 940; H. Lipowska 1250; H. Rysianka 1150; g, Trzy Kopce 1200, 1215; H. Redykalna 1030; dol. Bystrej 875; dol. Z Widel 950; Śmierdzący Potok 760, 1010; Zająców Potok 840, 1090; Złotnice 925; pot. Z Gawłowskiego 675, 770; Szeroki Kamieniec 800; pot. Połom 790; Potok Jakubowski 600, 680; Sułki 665; Placówka 710; dol. Stara Piła 780, 900; Złatna 610; Herdula 695; Jastrzębie 600; pot. Głęboki 595, 650; gajówka Straceniec 775; g. Okrągła 1000; g. Długi Groń 850; Polany Pod Soblówką 900; pol. Pogwarówka 925; pol. Plekońka 960; pol. Krawcula 1000; g. Krawców Wierch 1065; dol. Straceniec 695. BG: las poniżej H. Czarnej 1040; las powyżej H. Czarnej 1140, 1200, 1260; las poniżej Sokolicy 1090; Sokolica 1310, 1390; Cyl 1515; las poniżej Akademickiej Perci 1235, 1300; Akadmicka Perć 1570; las m. Markowymi Szczawinami a przeł. Brona 1225; Kościółki 1580; poniżej Diablaka 1600; pot. Kiczorka 1360; H. Kralowa 1080, 1255. J: dol. Zasepnicy 380; g. Czerniańska 690; g. Gawronowa 580; pot. Czerna 500; Drwalówka 690; Nowy Świat 570; g. Grzechynia 500; Skupniówka 525, 550; g. Skupniówka 650; dol. Huciska 520; g. Magurka 870; Matusy 520; Boguniówka 525; Kępy 550; Roztoki 610, 650, 700; g. Babiarzówka 870; Zimna Woda 675; g. Jałowiec 1100; m. g. Jałowiec a g. Lachów Groń 800, 850; pot. Kolędówka 650; pot. Opaczmy 700; pot. Surmiaków Potok 580; las Czarniawa 940; H. Kubalkowa 1000; g. Biały Wierch 1040; Beskidek 1010; przeł. Klekociny 930; dol. Magurki 830; pot. Głucha 600; poniżej H. Kamińskiego 1000; poniżej g. Mędralowa 850; g. Mędralowa 1150 .

H. tubulosa (Schaer.) Hav. - Kora drzew iglastych, również ich gałązki, rzadziej kora drzew liściastych bądź martwe drewno; rg. d., rg. g.

28 stan. WR: Zagajka 625; g. Wiertalówka 895; g. Jaworzyna 930; pol. Skrzadnita 1105; g. Będoszka Wielka 1100; g. Muńczoł 1115, 1150; g. Wielka Racza 1235. P: Złatna 600; Placówka 710; Kotrysia Polana 730; przeł. Przysłopy 860; pot. Stara Piła 900; g. Okrągła 940; g. Kotarnica 950; pol. Plekońka 960; g. Jaworzyna 1025; H. Lipowska 1100; H. Wieprzska 1130; g. Rysianka 1320; g. Palenica 1340. BG: las powyżej H. Czarnej 1260. J: Barankowa 800; poniżej g. Mędralowa 850.

H. vittata (Ach.) Parrique - Omszałe pnie starych drzew, głównie świerków i buków rosnących w naturalnych lasach; rg. d., rg. g.

36 stan. WR: las Orzeł 960, 1020; rez. Śrubita 990; g. Bednarów Beskid 1050; g. Muńczoł 1100; pol. Skrzadnita 1105; g. Rycerzowa Wielka 1120, 1195. P: Zająców Potok 850, 910; rez. Rysianka 1010, 1130; H. Lipowska 1100; H. Wieprzska 1120; H. Bacmańska 1150; g. Szczawinka 1200, 1240, 1310, 1315; H. Bieguńska 1150; pol. Bartek 1150; g. Lipowska 1260, 1280, 1310; H. Mędralowa 1290, 1340; g. Rysianka 1300; g. Palenica 1320; g. Romanka 1335, 1355, 1365; g. Pilsko 1350. BG: las powyżej H. Czarnej 1200; las m. Markowymi Szczawinami a przeł. Brona 1280; pot. Kiczorka 1360. J: H. Kamińskiego 1050; g. Mędralowa 1150.

Hypotrachyna sinuosa $(\mathbf{S m}$.$) Hale [= Parmelia sinuosa (\mathrm{Sm}$.$) Ach.] - Kora$ starych jodeł. Według SuZY (1951) rośnie na Babiej Górze; obecnie nie potwierdzony.

Icmadophila ericetorum (L.) A. Zahlbr. - Butwiejące pniaki i kłody, omszałe głazy i skałki; miejsca cieniste; rg. d., rg. g., kos. 
22 stan. WR: U Jurzycowej 670; pot. Urwisko 700; k. pol. Kapotkula 720; pot. Racza 900; rez. Oszus 950. P: Sikorczany Potok 735; pot. Glinna 1120, 1230; g. Romanka 1120; g. Szczawinka 1215; g. Pilsko 1340, 1400, 1450. BG: m. Markowymi Szczawinami a pot. Marków 1140; Cyl 1485; powyżej Sokolicy 1390; m. Kościółkami a przeł. Brona 1490; Akademicka Perć 1610; Diablak 1680. J: przeł. Jałowiecka 1017.

Immersaria athroocarpa (Ach.) Rambold \& Pietschm. [= Lecidea athroocarpa (Ach.) Ach.] - Bezwapienne piaskowce (skałki, głazy, kamienie); miejsca widne i suche; rg. d., rg. g, kos.

40 stan. WR: g. Klimasy 710; g. Oźna 930; g. Jaworzyna 900; H. Śrubita 1000; pol. Kołyska 1010; g. Praszywka Duża 1030, 1040. P: Kolonia 750; g. Bucioryska 795; g. Magura 850; g. Przypór 880; pol. Buczynka 880; Polany Pod Soblówką 900; g. Prusów 965; g. Łazy 965; g. Kotarnica 1010; pol. Krawcula 1035; g. Skałka 1130; H. Bieguńska 1160; g. Pilsko 1385. BG: Kępa 1520; Kościółki 1400, 1580, 1600; Diablak 1610, 1680, 1700, 1710, 1725. J: N stok g. Czerniańska 450; dol. Wilkówki 470; m. g. Jaworzyna a g. Szelust 900; g. Magurka 870; g. Skupniówka 600; g. Surzynówka 800; H. Trzebuniaków 1050.

Imshaugia aleurites (Ach.) S. L. F. Meyer [ = Parmeliopsis aleurites (Ach.) Nyl.] - Kora świerków, martwe drewno (dachy szałasów), wyjątkowo kora drzew liściastych (wolno rosnące buki); $\mathrm{rg}$. d.

9 stan. WR: pol. Cerla 1055. P: g. Bucioryska 795; g. Prusów 1005; g. Boraczy Wierch 1160. J: pot. Stracony Potok 650; dol. Magurki 800; g. Mędralowa 850; Figury 870; las Czerniawa 940.

Ionaspis odora (Ach.) Th. Fr. in Stein - Bezwapienne piaskowce (kamienie) zagłębione lub zalewane wodą $\mathrm{w}$ czystych potokach górskich (przeważnie $\mathrm{w}$ źródliskowej części w wyższych położeniach); rg. g.

2 stan. P: H. Cudzichowa 1175; źródła pot. Glinna 1350.

Kiliasia tristis (Müll. Arg.) Hafellner [= Catillaria subnitida Hellb.] - Skałki i głazy wapienne, np. koło dróżek polnych; miejsca widne i suche; pg.

1 stan. P: m. Sporyszem a g. Grojec 390.

Lecanactis abietina (Ach.) Koerb. - Kora starych świerków, rzadziej jodeł; rg. d., rg. g.

21 stan. WR: g. Bednarów Beskid 920; rez. Oszus 950, 1080; las Orzeł 980. P: rez. Rysianka 900, 1080, 1100; pol. Między Młaki 1200; pot. Glinna 1200, 1260, 1300; g. Romanka 1210, 1350; g. Lipowska 1260, 1310; g. Rysianka 1300. BG: las poniżej Sokolicy 1230; las m. Markowymi Szczawinami a przeł. Brona 1255, 1310; las poniżej Akademickiej Perci 1235, 1340.

L. dilleniana (Ach.) Koerb. - Bezwapienne piaskowce (pionowe, suche lecz cieniste skały); rg. d., rg. g.

2 stan. P: g. Skałka 1195; g. Romanka 1300.

L. latebrarum (Ach.) Arnold [ = Lepraria latebrarum (Ach.) Ach.] - Bezwapienne piaskowce (pionowe lub podwieszone, zacienione skały); rg. d., rg. g.

4 stan. P: Na Piętrze 800; g. Boraczy Wierch 1100; g. Romanka 1225; g. Szczawinka 1315.

Lecanora albella (Pers.) Ach. $[=$ L. pallida (Schreb.) Rabenh.] - Kora drzew liściastych i iglastych (jodły); miejsca widne w naturalnych drzewostanach; rg. d. 27 stan. WR: pot. Czadeczka 530; g. Trojaki 660; pot. Rycerka 650; Rycerki 655; pot. Plaskurówka 700; pot. Urwisko 705; leśniczówka Pod Raczą 715; pol. Ziajówka 850; g. Praszywka Duża 970; g. Pleskierówka 1085; g. Rycerzowa 1120. P: Złatna 600; Sułki 665; pot. Kościelec 700, 730, 735; pot. Boracza 700; Placówka 710; pot. Połom 790; Zająców Potok 910; pol. Między Młaki 1200. J: Kępy 500; dol. Głucha 630; Kowalówka 700; dol. Koszarawy 800; przeł. Klekociny 930; H. Kamińskiego 1118.

L. albescens (Hoffm.) Branth \& Rostr. - Wapienie, beton (mosty, wiadukty, mury, parkany), wyjątkowo stare kości; pg., rg. d.

6 stan. WR: Rycerka 515; Zwardoń 660; pot. Rycerka 580; g. Ożna 980. P: m. Sporyszem a g. Grojec 390. J: g. Wełczon 840. 
L. allophana Nyl. - Kora drzew liściastych, np. dębów rosnących przy drogach leśnych; rg. d.

1 stan. P: Sułki 665.

L. argentata (Ach.) Malme $[=L$. subfuscata H. Magn. $]$ - Kora drzew liściastych i iglastych; rg. d.

85 stan. WR: g. Trojaki 615; g. Biernatka 700; g. Rachowiec 850; dol. Cicha 600; g. Muńczoł 1115; dol. Rycerki 630; dol. Plaskurówki 700; Słonkówka 750; Żebrakówka 800; Skomisko 680; g. Pleskierówka 1090; Raztoki 700; g. Będoszka Wielka 1120; las Na Kołysce 1000; g. Majcherowa 950; g. Wielka Racza 1100, 1200; g. Upłaz 1020; Przegibek 1000; dol. Urwiska 780; g. Bednarów Beskid 1020; las Orzeł 1030; g. Bugaj 1050; g. Jaworzyna k. Bugaja 1100, 1150. P: pol. Żor 700; las Gajka 500; g. Prusów 1005; pol. Buczynka 860; pol. Alacowa 925; pol. Koziorka 800; H. Łyśniowska 1190; pol. Szczyrkowe Młaki 910; H. Bacmańska 1125; m. g. Trzy Kopce a H. Rysianka 1160; g. Magurka k. Trzech Kopców 1035; Zająców Potok 1050; Na Piętrze 835; Placówka 710; dol. Stara Piła 700; pot. Kościelec 700, 730; Jakubowski Potok 600; g. Okrągła 925, 1000; Jastrzębie 660; dol. Straceńca 695; pol. Plekońka 960; Polany Pod Soblówką 900. BG: las poniżej H. Czarnej 1040. J: dol. Zasepnicy 380, 400; powyżej Drwalówki 640; gajówka W Gawronce 750; Kowaliczki 600; g. Magurka 870; g. Urwisko 610; Boguniówka 525; Roztoki 650; Złabne 680; g. Jałowiec 1100; pot. Surmiaków Potok 580; H. Trzebuniaków 1030; dol. Bystrej 590, 800; Beskidek 1010; pol. Magurka 825; dol. Głucha 600; poniżej H. Kamińskiego 1000; g. Mędralowa 1150.

L. campestris (Schaer.) Hue - Nieznacznie wapniste piaskowce; miejsca suche i widne; pg., rg. d.

2 stan. WR: g. Łysica 550. P: g. Grojec 610.

L. carpinea (L.) Vain. - Gładka kora drzew liściastych rosnących nad potokami, rzekami, obok dróg, zabudowań lub samotnie (miedze); pg., rg. d.

53 stan. WR: pot. Krążelka 520; pot. Czadeczka 545; Tarliczne 590; Wełniakówka 590; g. Biernatka 700; dol. Cicha 590; Rycerki 650; pot. Rycerka 630; Pętkówka 650; pot. Plaskurówka 700; pot. Urwisko 715, 780; leśniczówka Pod Raczą 715; Żebrakówka 800; g. Jaworzyna 885; g. Praszywka Duża 790; Przegibek 1000; Wiertalówka 1065; H. Rycerzowa 1100; g. Będoszka Wielka 1120. P: leśniczówka Janikówka 415; Jeleśnia 415; pot. Nickulina 500; Złatna 600; Sułki 665; Kotrysia Polana 720; leśniczówka Straceniec 775; pot. Kościelec 840; g. Okrą̧gła 925; g. Prusów 1000; Zająców Potok 1050; H. Motykowa 1050; H. Miziowa na Romance 1075; H. Łyśniowska 1190. J: g. Gawronowa 580; Janiczki 500; Hyrby 670; dol. Huciska 500, 520; Skupniówka 525; Matusy 520; Boguniówka 525; g. Kiczora 880; Zimna Woda 680; pot. Kolędówka 650; pot. Surmiaków Potok 600; g. Czerniawa Sucha 1030; dol. Bystrej 590; pol. Magurka 825; H. Kamińskiego 1050.

L. cenisia Ach. - Bezwapienne piaskowce (głazy na polanach i halach, stosy kamieni, luźne murki); miejsca widne i suche; rg. d., rg. g., kos.

40 stan. WR: g. Zabawa 600, 700; g. Burów Groń 690; Na Praszywce 950; H. Śrubita 1000; g. Jaworzyna 1000; pol. Kołyska 1010; g. Bugaj 1050; g. Będoszka Wielka 1100; H. Muńczoł 1120. P: Dziaski 735; Sucha Góra 750, 1000; pol. Na Boruć 895; Polany Pod Soblówką 900; g. Łazy 995; pol. Gruszkowa 1000; g. Prusów 1005; pol. Krawcula 1035; H. Motykowa 1050; H. Wieprzska 1100; H. Szczawina 1115; H. Lipowska 1140; H. Bieguńska 1160; g. Rysianka 1300: BG: Suchy Potok 1365; Akademicka Perć 1480; Kościółki 1510; Diablak 1600, 1650, 1660, 1700, 1710. J: dol. Grzechynki 450; g. Czerniańska 500; g. Gawronowa 580; Koszarawa (u wylotu dol. Bystrej) 590; g. Kamienna 740; g. Magurka 870; g. Lachów Groń nad Bystrą 1045.

L. chlarotera Nyl. - Kora drzew liściastych rosnących w lasach naturalnych i przy drogach; pg., rg. d.

18 stan. WR: pot. Krążelka 520; Rycerka Dolna 525; Rycerki 655; pot. Urwisko 705; Żebrakówka 800; g. Praszywka Duża 970. P: Kotrysia Polana 720; leśniczówka Straceniec 775; Zająców Potok 1050. BG: pot. Jałowiec 635. J: dol. Czernej 430; pot. Surmiaków Potok 600; Wełcza 630; g. Drwalowa 680; Złabne 680; dol. Cicha 700; g. Surzynówka 700. 
L. conizaeoides Nyl. ex Cromb. - Kora drzew liściastych i iglastych, głównie w siedliskach zmienionych przez człowieka; gatunek prawdopodobnie przeoczony; rg. d.

3 stan. P: pol. Żor 700. J: pot. Surmiaków Potok 580; g. Ostra Górka 600.

L. dispersa (Pers.) Sommerf. - Wapienie, wapniste piaskowce, podłoże betonowe; pg., rg. d., kos.

30 stan. WR: pot. Nieledwianka 400; pot. Czadeczka 500; pot. Krążelka 510; Rycerka 515; Zwardoń 650; g. Ochodzita 760; g. Łysica 550; Tanistry 555; pot. Rycerka 580; pol. Masarka 720; pot. Danielka 725; g. Hutyrów 740; g. Oźna 950. P: Sporysz 390; g. Grapa Żar 430; pol. Bugaj 580; g. Grojec 610; g. Abrahamów 700; Zająców Potok 800; H. Durajka 835; g. Skałka 1195. BG: ruiny schroniska pod Diablakiem 1600. J: m. Grzechynią a Skupniówką 450; dol. Gołyńki 520; dol. Kalinki 540; Roztoki 680; g. Welczon 840 ; pol. Skalaniec 850 .

L. expallens Ach. - Kora drzew liściastych; tylko w stanie płonnym; pg., rg. d. 25 stan. WR: g. Popręcina 685; Pławuchowa 520; dol. Cicha 590. P: Przyłęków 475; las Gajka 500; pot. Nickulina 500; Złatna 600; Żabnicka Rzeka 600; Sułki 665; Kotrysia Polana 730; g. Kotarnica 1000. J: g. Sumerówka 565; powyżej Drwalówki 690; Janiczki 500; g. Grzechynia 550; Pytel 600; Skupniówka 525; poniżej Pytla 550; g. Magurka 870; g. Urwisko 610; Boguniówka 525; pot. Kolędówka 650; pot. Surmiaków Potok 580; Wełcza 630; H. Kamińskiego 1100.

L. hagenii (Ach.) Ach. - Kora drzew liściastych samotnie rosnących, przydrożnych (jarzębiny, jesiony), przeważnie u nasady pni i w miejscach wystawionych na kurz, rzadko na drzewach iglastych; rg. d.

3 stan. WR: Szczotka 900; g. Wielka Racza 1100. P: Sopotnia Wielka 620.

L. intricata (Ach.) Ach. - Bezwapienne piaskowce w miejscach suchych i widnych (stosy kamieni, luźne murki, głazy po halach i polanach), wyjątkowo na korze drzew liściastych u nasady pni i przy korzeniach (buki, jawory); pg., rg. d., rg. g., kos. 167 stan. WR: g. Ochodziła 820; g. Zabawa 600, 655, 740, 760, 800; g. Kiczorka 685, 725, 795; Głębokie 660; Młaki 700; Do Staroni 770; g. Kiczora 790; Tomusie 575; H. Rachowiec 910; g. Klimasy 710; g. Hutyrów 670; g. Skalanka 800; Rycerka 500; g. Beskid Wrzeszcz 860; g. Oźna 780, 870, 920, 930, 950; g. Burów Groń 690; g. Kokocz 720; Stawiska 770; m. górami Jaworzyną i Magurą 945; g. Jaworzyna 900, 985, 1020; g. Praszywka Duża 1030; pol. Wyrobniówka 925; g. Muńczoł 1120, 1165; g. Magura 1050; Magura 850; Przysłop Połucki 870; pol. Joneczkowe Rycerki 715; pol. Raztoki 750; Pod Raczą 715; H. Przysłop 940; g. Będoszka Wielka 1100; pol. Kołyska 1010; g. Rycerzowa 1170; H. Mała Racza 1070; g. Wielka Racza 1235; H. Śrubita 1000; g. Bugaj 1050; g. Abramów 1080. P: g. Jastrzębica 750; Duraje 610; g. Przypór 855; m. górami Kiczora i Magura 840; g. Magura 850, 870, 970; Sopotnia Wielka 735; g. Kotarnica 1010, 1160; g. Łazy 965; g. Palenica 630; g. Abrahamów 780; Tokarnia 890; H. Miziowa na Romance 1100; dol. W Ciemnym 900, 1170; pol. Boruć 895; g. Prusów 965, 1000, 1005; g. Baścikówka 810; H. Wieprzska 1060, 1100; g. Skałka 1130, 1195; Kolonia 750; pol. Buczynka 880; Milówki 785, 920; pol. Alacowa 925; g. Baśkówka 850; m. przys. Sznurki i Dadoki 865; przel. Pawlusia 1170; H. Rysianka 1240, 1300; g. Pilsko 1375, 1420, 1450; H. Cebulowa 1270; H. Cudzichowa 1260; pol. Szczyrbowe Młaki 910; m. Halami Miziową i Jodłowcową 1250; g. Solisko 1180; H. Bieguńska 1160; H. Lipowska 1140, 1200, 1250; g. Trzy Kopce 1215; pol. Sucha Góra 920, 1000, 1040; Graberki 850, 900; pol. Gruszkowa 1000; H. Motykowa 1050; Dziaski 735; g. Okrągła 900, 930, 940; g. Długi Groń 880; pol. Krawcula 1035; g. Kotelnica 760. BG: H. Czarna 1080; Suchy Potok 1365; Cyl 1460, 1480, 1515; Kościółki 1510, 1580; Akademicka Perć 1480; Diablak 1660, 1680, 1710; powyżej H. Kralowej 1395. J: g. Czerniańska 575; g. Gawronowa 580; pot. Czerna 500; Drwalówka 690; dol. Grzechynki 550; g. Kamienna 700; Kubiasiaki 690; g. Skupniówka 600, 650; g. Kwakowa 670; Janiki 770; g. Magurka 870; g. Surzynówka 800; g. Witkówka 740; dol. Kalinki 540; g. Kiczora 900; Figury 810; Jałowiec 750; Baranówka 700; pot. Kolędówka 650; Opaczne 960; H. Trzebuniaków 1050; H. Janoszkowa 1020; H. Kubalkowa 1000; pol. Skalaniec 900; g. Biały Wierch 1040; dol. Bystrej 590, 600; g. Kiklówka 745; g. Lachów Groń nad Bystrą 1045; g. Wełczon 800; Kijakowa 810; Podjałowiec 995; dol. Głucha 580; g. Mędralowa 1170; poniżej g. Przyborówka 850 . 
L. intumescens (Rebent.) Rabenh. - Kora drzew liściastych (głównie buki, rzadko jawory, klony, jarzębiny) rosnących w naturalnych lasach; rg. d., rg. g.

35 stan. WR: dol. Cicha 600; Pętkówka 650; Rycerki 655; pot. Urwisko 700; pot. Smerekówka Wielka 700; pot. Plaskurówka 700; leśniczówka Pod Raczą 715; pot. Racza 755; Żebrakówka 800; pol. Ziajówka 850; g. Przysłop Mały 960; pot. Śrubita 975; g. Muńczoł 990, 1115; Kołyska 1000; las Orzeł 1030. P: Złatna 600 ; pot. Straceniec 695, 775; pot. Kościelec 700, 840; Placówka 710; Kotrysia Polana 720; Na Piętrze 835; g. Długi Groń 850; g. Okrągła 925; H. Wieprzska 1060; H. Łyśniowska 1090. BG: las poniżej Akademickiej Perci 1340. J: dol. Głucha 600; Złabne 680; dol. Bystrej 800; pol. Magurka 800; przeł. Klekociny 930; H. Kamińskiego 1100.

L. leptyrodes (Nyl.) Degel. - Kora drzew liściastych rosnących w naturalnych lasach; rg. d.

5 stan. WR: g. Rachowiec 850; pot. Rycerka 650; Żebrakówka 800; g. Praszywka Mała 900. P: Złatna 610.

L. muralis (Schreb.) Rabenh. - Wapienie oraz wapniste lub bezwapienne piaskowce (nierzadko na głazach nad brzegami potoków i rzek), również obiekty murowane i betonowe; pg., rg. d., rg. g., kos.

96 stan. WR: g. Syberia 550; pot. Nieledwianka 460; Pochodziła 760; g. Ochodzita 820; g. Zabawa 600; g. Kiczorka 685, 775; pot. Czadeczka 510; Myto 675; Rajcza 490; H. Rachowiec 910; Rycerka 515, 585; g. Hutyrów 740; Graniczne 790; Rycerka Dolna 550; Głębokie 660; g. Łysica 650; pot. Rycerka 580, 600; Stawiska 770; Szczytkówka 875; pol. Na Praszywce 950; g. Muńczoł 1105; pot. Z Głębokiego 550; pol. Wyrobniówka 900; m. Podścigłowem i Magurą 750; Rycerki 655; Młada Hora 940; Skomisko 680; pol. Raztoki 750; Pod Raczą 715; H. Przysłop 940; g. Będoszka Wielka 1100; H. Mała Racza 1070. P: g. Grojec 610; pol. Bugaj 580; g. Grapa Żar 430; Przyłęków 550; Duraje 610; pot. Bystra 510; H. Durajka 885; pot. Fułatów 575; g. Prusów 965; H. Wieprzska 1060; pot. Studziański 660; Żabnicka Rzeka 590; Milówki 700; Tokarnia 890; m. Sznurkami i Dadokami 865; g. Rysianka 1320; H. Bieguńska 1160; H. Lipowska 1140, 1200; H. Redykalna 1060, 1140; pol. Gruszkowa 1000; H. Motykowa 1060; Zająców Potok 800; g. Bucioryska 760; pot. Z Gawłowskiego 645; g. Okrągła 930; pot. Głębokie 580; g. Długi Groń 840; g. Kotelnica 750. BG: H. Czarna 1080; ruiny schroniska pod Diablakiem 1600. J: g. Sumerówka 565; dol. Zasepnicy 440; Drwalówka 690; dol. Czernej 550; dol. Grzechynki 450; dol. Wilkówki 475; g. Skupniówka 600; g. Magurka 870; Matusy 520; g. Witkówka 650; Topory 700; dol. Gołyńki 520; dol. Kalinki 540; g. Lachów Groń nad Skawicą 600; Roztoki 610, 620; g. Babiarzówka 860; Jałowiec 750; g. Surmiaków Groń 730; pot. Surmiaków Potok 550; g. Lachów Groń nad Bystrą 1045; pol. Skalaniec 850; dol. Bystrej 590, 700; g. Wełczon 850; H. Janoszkowa 1020; dol. Głucha 580; H. Kamińskiego.

L. phaeostigma (Koerb.) Almb. in R. Sant. [= L. obscurella (Sommerf.) Nyl.] - Murszejące drewno dachów, szałasów; rg. d.

1 stan. P: g. Kotarnica 1000.

L. polytropa (Ehrh. ex Hoffm.) Rabenh. - Bezwapienne piaskowce w miejscach suchych i widnych, rzadziej cienistych (stosy kamieni, luźne murki, kamieńce nadrzeczne, głazy nad potokami, po halach i polanach, skałki); pg., rg. d., rg. g., kos. 217 stan. WR: g. Ochodziła 820; g. Kiczorka 685, 725; Wierch Czadeczka 680; g. Zabawa 655, 800; g. Sołowy Wierch 840; Do Staroni 770; g. Podgórka 785; g. Kiczora 680, 700; Tomusie 575; g. Rachowiec 850, 950; g. Klimasy 710; g. Hutyrów 670; Ujsoły 520; Klimas 780; g. Beskid Wrzeszcz 860; Szczotka 870; g. Oźna 920, 930; Szczytkówka 875; pol. Szczytkówka 870; m. górami Jaworzyna i Magura 945; g. Jaworzyna 900; Obłaz 830; g. Praszywka Duża 970, 980, 1030; pol. Wyrobniówka 900, 925; H. Muńczoł 1120; g. Magura 1050; Magura 850; pol. Bułkowa 760; Przysłop Połucki 870; Rycerki 655; Młada Hora 985; Skomisko 680; pol. Cerla 1025; pol. Joneczkowe Rycerki 715; pol. Raztoki 750; pol. Majów 825; pot. Dzięboki 770; g. Będoszka Wielka 1100; pol. Kołyska 1010; H. Przysłop 940; g. Rycerzowa 1170, 1205; pol. Majcherowa 1075; H. Mała Racza 1070, 1120; g. Wielka Racza 1235; pol. Głowa 940; H. Śrubita 1000; g. Abramów 1080; g. Jaworzyna k. Bugaja 1100, 1120. P: g. Przypór 820, 850; pot. Bystra 510; g. Groń nad Przyłękowem 700; g. Jastrzębica 750; g. Kiczora 765; m. górami Kiczora i Magura 840; g. 
Magura 850, 870, 970; g. Abrahamów 700, 830; Sopotnia Wielka 735; g. Kotarnica 1010, 1015, 1160; g. Łazy 965; pot. Loraniec 480; g. Palenica 665; Tokarnia 780, 890; H. Miziowa na Romance 1100; g. Malarka 1050; H. Majerkowa 1075; dol. Do Jodłowcowej 725; pot. Suchy 630; pol. Boruć 795; g. Prusów 965, 1000, 1005; g. Baścikówka 810, 880; H. Wieprzska 1060; g. Skałka 1130, 1195; pol. Alacowa 925; Milówki 785, 920; m. Sznurkami i Dadokami 865; pol. Buczynka 880; przeł. Pawlusia 1190; H. Jodłowcowa 1200; leśniczówka Glinne 750; g. Rysianka 1300; g. Pilsko 1385, 1400, 1420, 1445, 1450, 1535; las powyżej H. Mędralowej 1320; H. Cebulowa 1270; H. Cudzichowa 1260; Sucha Góra 750; m. Halami Miziową i Jodłowcową 1250; g. Solisko 1180; H. Skórzacka 1125; H. Bieguńska 1160, 1200; H. Lipowska 1140, 1150, 1200, 1250; Kolonia 750; g. Trzy Kopce 1200, 1215; g. Sucha Góra 920, 1000, 1020, 1040; H. Redykalna 1060; pol. Gruszkowa 1000; Śmierdzący Potok 1025; Dziaski 735; Zająców Potok 1000; g. Bucioryska 795; g. Okrągła 850, 940, 950; pot. Głęboki 630; g. Długi Groń 880; pol. Pogwarówka 925; pol. Plekońka 960; pol. Krawcula 1035; g. Kotelnica 760; g. Kubiesówka 800; Polany Pod Soblówką 900. BG: H. Czarna 1080; Suchy Potok 1365; Kępa 1520; Cyl 1460, 1515; Kościółki 1500, 1510, 1580, 1600; Akademicka Perć 1590, 1610, 1670; m. Kościółkami a Diablakiem 1625; Główniak 1570; powyżej przeł. Brona 1450; Diablak 1650, 1660, 1675, 1680, 1700, 1725; S stok Diablaka 1600, 1610; pot. Kiczorka 1395. J: N stok g. Czarna 450; g. Sumerówka 565; Drwalówka 690; g. Kamienna 700; g. Ostra Górka 610; dol. Wilkówki 475; Kubiasiaki 690; g. Skupniówka 600; g. Kwakowa 670; Janiki 770; g. Magurka 870; g. Surzynówka 800; g. Janoszka 720; g. Kiczora 900; Figury 810; Kolędówka 800; g. Surmiaków Groń 730; Baranówka 700; g. Jałowiec 1110; pot. Kolędówka 650; H. Kubalkowa 1100; Opaczne 960; H. Trzebuniaków 1050; H. Janoszkowa 1020; pol. Skalaniec 900; g. Biały Wierch 1040; g. Kiklówka 745; g. Lachów Groń nad Bystrą 1045; g. Wełczon 800, 820; Beskidek 1010; dol. Bystrej 700; Kijakowa 810; pol. Magurka 880; Podjałowiec 995; H. Kamińskiego 1118; Pindelówka 1050; dol. Głucha 730; g. Przyborówka $850 ;$ m. g. Jaworzyna a g. Szelust 900.

L. pulicaris (Pers.) Ach. $[=$ L. chlarona (Ach.) Nyl., L. pinastri (Schaer.) H. Magn.] - Kora drzew liściastych, równie często martwe drewno (parkany, drewniane dachy szop i szałasów, pniaki); pg., rg. d., rg. g.

44 stan. WR: pot. Czadeczka 545; Wełniakówka 590; Rycerki 640; Kolonia 670; Raztoki 700; pol. Bułkowa 760; g. Praszywka Mała 840; H. Przysłop 950; g. Praszywka Duża 970; pol. Kołyska 1000; g. Wielka Racza 1100; g. Będoszka Wielka 1140; g. Muńczoł 1150. P: leśniczówka Janikówka 415; Złatna 600; pot. Z Gawłowskiego 675; Kotrysia Polana 730; pol. Koziorka 800; pol. Pogwarówka 925; pol. Krawcula 1035; H. Wieprzska 1175; g. Rysianka 1200, 1320; g. Palenica 1340. J: g. Sumerówka 565; Hyrby 670; Nowy Świat 570; g. Grzechynia 550; Skupniówka 525; Stryszawa 450; Pytel 550; dol. Huciska 520; g. Magurka 870; g. Skupniówka 600; Matusy 520; pot. Stracony Potok 600; g. Urwisko 610; Boguniówka 525; Kępy 550; Roztoki 650; pot. Kolędówka 650; pot. Surmiaków Potok 580; g. Czerniawa Sucha 1030; dol. Głucha 600.

L. rugosella A. Zahlbr. - Kora drzew liściastych, głównie wolno rosnących, np. koło dróg (jesiony, topole, wierzby, jarzębiny, osiki); pg., rg. d.

13 stan. WR: Nieledwia 580; Pławuchowa 520; Słonkówka 625; Kolonia 670; g. Jaworzyna 885. P: Przyłęków 475; Juszczyna 430; pot. Nickulina 500; Złatna 600, 610; Żabnicka Rzeka 600; Cisiec 650.

L. rupicola (L.) A. Zahlbr. subsp. subplanata (Nyl.) Leuckert \& Poelt - Bezwapienne piaskowce (stosy kamieni i luźne murki, rzadziej gołoborza, głazy po halach i polanach, naturalne skały); miejsca suche i widne; rg. d., rg. g., kos. 106 stan. WR: g. Syberia 570; g. Zabawa 600, 760, 800; Do Staroni 770; g. Podgórka 795; Tomusie 600; Staronie 760; Myto 675; Młaki 700; g. Kiczora 700; g. Rachowiec 850; Rycerka 515; Głębokie 660; g. Klimasy 710; g. Hutyrów 670; Rycerka Dolna 550; g. Skalanka 800; Szczotka 870; g. Burów Groń 690; g. Łysica 650, 680; g. Oźna 930, 950; Stawiska 770; Szczytkówka 875; g. Jaworzyna 900, 985, 1020; g. Praszywka Duża 1030, 1040; pol. Gardasówka 830; g. Muńczoł 1120; Przysłop Połucki 870; Rycerki 655; Skomisko 680; pol. Cerla 1025; pol. Raztoki 750; H. Przysłop 940; g. Będoszka Wielka 1100; g. Rycerzowa 1170; pol. Kołyska 1010; g. Abramów 1080. P: g. Grojec 610; g. Jastrzębica 750; g. Przypór 880; g. Magura 850, 870; g. Grapa 600; g. Kotarnica 1010; g. Łazy 965; g. Palenica 665; g. Abrahamów 780; pol. Na Boruć 895; g. Prusów 965, 1005; g. Malarka 1050; H. Wieprzska 1060; Kolonia 750; pol. Buczynka 880; pol. 
Alacowa 925; g. Skałka 1195; m. Sznurkami i Dadokami 865; g. Pilsko 1385, 1420; Graberki 850; g. Sucha Góra 960, 1000; H. Redykalna 1080; Dziaski 785; pot. Głębokie 580; pol. Krawcula 1035; g. Kotelnica 760; Polany Pod Soblówką 900. BG: Sokolica 1370; Diablak 1725. J: dol. Grzechynki 450; m. Grzechynią a Skupniówką 450; dol. Gołyńki 520; dol. Kalinki 540; pot. Surmiaków Potok 550; g. Czerniańska 570; g. Gawronowa 580; g. Lachów Groń nad Skawicą 600; g. Skupniówka 600; przys. Witkówka 650; g. Surzyny 670; Kubiasiaki 690; Drwalówka 690; Figury 700; dol. Bystrej 700; g. Kamienna 720; g. Surmiaków Groń 730; Janiki 770; g. Surzynówka 800; Kolędówka 800; g. Wełczon 840; poniżej g. Przyborówka 850; g. Magurka 870; m. g. Jaworzyna a g. Szelust 900; pol. Skalaniec 900; g. Kiczora 900; Opaczne 960; Podjałowiec 995; g. Lachów Groń nad Bystrą 1045; H. Trzebuniaków 1050.

L. saligna (Schrad.) A. Zahlbr. [= L. sarcopis (Ach.) Ach. $]$ - Kora drzew liściastych oraz martwe drewno (pniaki, parkany); pg., rg. d., rg. g.

28 stan. WR: pot. Krążelka 500; Szpaki 570; Chromiczaki 680; Laliki Wielkie 700; g. Ochodzita 760; Rycerki 640; Szczotka 900; Pławuchowa 520; g. Oźna 950; pol. Cięcianówka 920; g. Wielka Racza 1100. P: dol. W Ciemnym 900; Śmierdzący Potok 1055; H. Redykalna 1080; H. Wieprzska 1120; H. Bacmańska 1125; g. Trzy Kopce 1215; g. Boraczy Wierch 1240; g. Lipowska 1300; g. Rysianka 1300; g. Palenica 1340; pot. Nickulina 520; Sopotnia Wielka 620; g. Prusów 1000; H. Łyśniowska 1160. J: Złabne 680; stoki g. Jałowiec nad dol. Koryciny 1000; Pindelówka 1000.

L. sarcopidoides (Massal.) A. L. Sm. [= L. pumilionis (Arnold) Arnold $]$ Martwe drewno oraz kora drzew iglastych; rg. d.

3 stan. WR: Lastoczka 675. P: Śmierdzący Potok 1010. J: g. Witkówka 700.

L. soralifera (Suza) Räs. - Bezwapienne piaskowce w miejscach suchych i widnych, głównie na świeżym podłożu (stosy kamieni); tylko w stanie płonnym; rg. d., rg. g., kos.

26 stan. WR: g. Kiczora 700; g. Łysica 630; g. Jaworzyna 865; Szczytkówka 875. P: Kolonia 750; g. Kiczora 765; pol. Buczynka 880; g. Łazy 965; g. Prusów 1000; pol. Krawcula 1035; g. Malarka 1050; H. Cudzichowa 1250. BG: Kępa 1520; Kościółki 1600. J: g. Gawronowa 580; g. Kamienna 720; g. Cuprynik 720; g. Wełczon 800, 850; g. Magurka 870, 900; pol. Skalaniec 900; m. g. Jaworzyna a g. Szelust 900; Podjałowiec 965; g. Biały Wierch 1040; H. Trzebuniaków; H. Kubalkowa 1080.

L. subaurea A. Zahlbr. $[=L$. hercynica Poelt \& Ullrich $]$ - Bezwapienne piaskowce; rg. d.

1 stan. WR: g. Hutyrów 670.

L. subcarpinea Szat. [ = L. nemoralis Mak.] - Kora szarych olch rosnących nad potokami; rg. d.

2 stan. WR: dol. Cicha 590. J: Boguniówka 600.

L. subrugosa Nyl. - Kora starych buków, rzadko innych drzew liściastych, zawsze w naturalnych lasach; rg. d.

46 stan. WR: g. Trojaki 660; dol. Cicha 590, 600; Pętkówka 650; Rycerki 680; pot. Przegibek 780; rez. Śrubita 950, 990, 1000; rez. Oszus 950, 1075; g. Przysłop Mały 960; Kołyska 1000; las Orzeł 1030; g. Bugaj 1050; g. Pleskierówka 1085; H. Rycerzowa Wielka 1100, 1195; pol. Skrzadnita 1105. P: pot. Kościelec 700; Placówka 710; pol. Koziorka 800; g. Długi Groń 840; g. Okrągła 925, 1010; H. Motykowa 1050; Zająców Potok 1050; H. Łyśniowska 1090, 1190; H. Lipowska 1100; g. Jodłowcowa 1100, 1200; H. Rysianka 1100, 1200; H. Wieprzska 1120; H. Bacmańska 1125; H. Bieguńska 1150; H. Pawlusia 1190. BG: pot. Marków 1125. J: Głuchaczki 980; Beskidek 1000; Pindelówka 1000; H. Kamińskiego 1100; g. Mędralowa 1150.

L. sulphurea (Hoffm.) Ach. [= Lecidea sulphurea (Hoffm.) Wahlenb. $]$ - Bezwapienne lub słabo wapniste piaskowce (skałki i głazy na halach, gołoborza, rzadko stosy kamieni i luźne murki); rg. d., rg. g., kos.

16 stan. WR: g. Klimasy 710; g. Łyska 640; g. Łysica 650; Rycerka Dolna 550; g. Praszywka Duża 1040; g. Bugaj 1050; g. Rycerzowa 1170. P: g. Grapa 600; H. Motykowa 1050; H. Malarka 1050; g. Pilsko 1385, 1450. BG: Diablak 1725. J: dol. Wilkówki 475; g. Lachów Groń nad Skawicą 600; g. Wełczon 875. 
L. symmicta (Ach.) Ach. [= Lecidea symmicta (Ach.) Ach.] - Kora, najczęściej gładka drzew liściastych (nad potokami), niekiedy gałęzie drzew iglastych (świerki, kosodrzewina) lub murszejące drewno; rg. d., rg. g., kos.

11 stan. WR: Odkrzas 670; Rycerki 620. P: pol. Buczynka 860; pol. Między Młaki 1235; pot. Z Gawłowskiego 675; leśniczówka Glinne 750; leśniczówka Straceniec 775; H. Rysianka 1200; g. Romanka 1360; g. Pilsko 1450. J: H. Kamińskiego 1050.

L. umbrina (Ach.) Massal. - Bezwapienne lub nieco wapniste piaskowce, beton, wapienie; pg., rg. d., kos.

14 stan. WR: pot. Czadeczka 500; dol. Z Głębokiego 550; Ujsoły 520; Tanistry 555; g. Oźna 950. P: Sporysz 420; g. Grapa Żar 430; pot. Bystra 510; Zająców Potok 800; g. Kubiesówka 800; Tokarnia 890. BG: ruiny schroniska pod Diablakiem 1600. J: m. Grzechynią a Skupniówką 470; dol. Bystrej 700.

L. varia (Hoffm.) Ach. - Martwe drewno (parkany, poręcze mostów), kora drzew; pg., rg. d.

17 stan. WR: pot. Nieledwianka 440; Kasperki 670; Rycerka Dolna 540; Rycerki 645; g. Praszywka Mała 840; Młada Hora 900. P: Figury 575; pol. Buczynka 880; pol. Pogwarówka 925; g. Kotarnica 950, 1000; g. Prusów 975. J: Stryszawa 450; Nowy Świat 570; Hyrby 640; Kolędówka 810; g. Magurka 870.

Lecidea atomaria Th. Fr. - Bezwapienne piaskowce (kamienie); miejsca widne i suche; rg. d.

3 stan. P: pol. Boruć 840. J: dol. Bystrej 750; H. Kamińskiego 1100.

L. caesioatra Schaer. - Obumierające mchy naskalne; kos.

5 stan. BG: Akademicka Perć 1555; Kościółki 1580, 1600; m. Kościółkami a Diablakiem 1625; poniżej Diablaka 1610.

L. confluens (Web.) Ach. - Bezwapienne piaskowce (skałki, często nad potokami i na gruzowiskach w wyższych położeniach); rg. d., rg. g., kos.

37 stan. WR: g. Muńczoł 1120. P: g. Kubiesówka 850; H. Szczawina 1115; H. Jodłowcowa 1160; H. Bieguńska 1200; H. Lipowska 1250; H. Cudzichowa 1250; H. Cebulowa 1270; g. Pilsko 1320, 1445, 1500, 1535. BG: Cyl 1485; poniżej Cyla 1460; Suchy Potok 1365; Akademicka Perć 1480, 1590, 1660; Główniak 1570; Kościółki 1500, 1510, 1580, 1600; m. Kościółkami a Diablakiem 1625; Diablak 1650, 1660, 1675, 1725; S stoki Diablaka 1580, 1600, 1610. J: g. Lachów Groń nad Bystrą 1045; g. Magurka 850.

L. fuscoatra (L.) Ach. - Bezwapienne piaskowce (stosy kamieni, luźne murki, rzadko naturalne skałki, często na kamieńcach nadrzecznych); miejsca widne i suche; pg., rg. d., rg. g.

122 stan. WR: g. Ochodzita 820; g. Kiczorka 685; Młaki 700; Burdówka 690; Do Staroni 770; g. Podgórka 785; g. Zabawa 760; g. Kiczora 680, 700; Tomusie 600; Staronie 760; Głębokie 660; g. Rachowiec 850,910; g. Klimasy 710; pot. Z Głębokiego 550; g. Hutyrów 670; Rycerka Dolna 550; Klimas 780; g. Beskid Wrzeszcz 860; g. Oźna 920, 930; Szczytkówka 875; g. Dolański Groń 705; g. Łysica 680; g. Kokocz 720; Ujsoły 520; Oźna 870; dol. Danielki 650; g. Jaworzyna 985, 1020; g. Praszywka Duża 950, 970, 1030; H. Muńczoł 1120; Magura 580; Przysłop Połucki 870; Rycerki 655; Młada Hora 985; pol. Cerla 1025; pol. Joneczkowe Rycerki 715; H. Przysłop 940; pol. Majów 825; g. Będoszka Wielka 1100, 1130; pol. Kołyska 1010; g. Rycerzowa 1170; g. Wielka Racza 1100; H. Mała Racza 1070; g. Abramów 1080. P: g. Grapa Żar 430; Sporysz 420; g. Groń nad Przyłękowem 700; g. Jastrzębica 750; Duraje 610; g. Przypór 820, 895; Na Skale 860; H. Durajka 835; g. Magura 870; H. Majerkowa 1075; pol. Na Boruć 995; g. Prusów 965, 1000; g. Malarka 1050; g. Baścikówka 810; Sopotnia Wielka 735; g. Kotarnica 1010; g. Łazy 965; g. Abrahamów 780; H. Wieprzska 1060; g. Skałka 1130, 1195; pol. Buczynka 880; Kolonia 750; pol. Alacowa 925; H. Szczawina 1115; H. Boracza 785; m. Sznurkami i Dadokami 865; H. Cudzichowa 1260; H. Bieguńska 1160; H. Lipowska 1250; pol. Szczyrbowe Młaki 885; H. Redykalna 1140; pol. Gruszkowa 1000; Dziaski 735; g. Okrągła 930; Głębokie 580; g. Długi Groń 880; pol. Plekońka 960; pol. Krawcula 1035; g. Kotelnica 760; g. Kubiesówka 790. BG: H. Czarna 1080. J: g. Biały Wierch 1040; dol. Bystrej 700; powyżej Drwalówki 690; Figury 810; g. Gawronowa 580; pot. Głucha 580; Janiki 770; g. Janoszka 670; dol. Kalinki 540; g. Kamienna 700; H. Kamińskiego 1118; g. Kiczora 900; Kolędówka 800; g. Magurka 870; 
Podjałowiec 995; g. Mędralowa 1170; Opaczne 900; Pindelówka 1050; pol. Skalaniec 900; g. Skupniówka 600 ; g. Sumerówka 565; g. Surmiaków Groń 730; g. Surzynówka 800; H. Trzebuniaków 1050; g. Wełczon 800 ; g. Witkówka 650.

\section{L. lactea Flk. ex Schaer. $[=$ L. pantherina (Ach.) Th. Fr. $]$ - Bezwapienne} piaskowce (naturalne skałki, luźne murki, stosy kamieni i głazy na halach i polanach); miejsca suche i nasłonecznione; pg., rg. d., rg. g., kos.

104 stan. WR: Do Staroni 770; g. Podgórka 795; g. Zabawa 740, 760, 800; g. Klimasy 710; g. Kiczora 685; g. Kiczorka 685; g. Rachowiec 850; m. Jaworzyną i Magurką 945; g. Jaworzyna 900; pol. Kołyska 1010; Pod Raczą 715; Przysłop Połucki 870; g. Praszywka Duża 980, 1040; H. Mała Racza 1070; H. Przysłop 940; g. Hutyrów 670, 700; pol. Gardasówka 830; H. Muńczoł 1120; Szczytkówka 875; g. Będoszka Wielka 1100; g. Skalanka 800; g. Beskid Wrzeszcz 860; Szczotka 870; g. Oźna 880; g. Bugaj 1050; g. Kokocz 720; Rycerka Dolna 515; g. Rycerzowa 1120. P: g. Jastrzębica 750; H. Wieprzska 1060; H. Redykalna 1080; H. Skórzacka 1125; H. Bieguńska 1160; H. Lipowska 1250; g. Skałka 1130; poniżej H. Majerkowej 1070; Sopotnia Wielka 705; g. Kotarnica 1010; poniżej pol. Łazy 995; g. Pilsko 1385, 1400, 1450; g. Długi Groń 880; pol. Plekońka 960; pol. Krawcula 1035; g. Trzy Kopce 1215; H. Cudzichowa 1260; H. Durajka 835; g. Przypór 820, 855; g. Prusów 920, 1000; Graberki 850; Milówki 900; g. Kubiesówka 860; H. Górowa 1100; H. Malarka 1000, 1050; g. Baścikówka 850. BG: Kępa 1520; Kościółki 1400, 1510; Diablak 1710, 1725; S stok Diablaka 1600, 1610, 1650, 1660. J: dol. Bystrej 600; Drwalówka 690; Figury 810; g. Gawronowa 580; pot. Głucha 730; H. Kamińskiego 1118; Kubiasiaki 690; g. Lachów Groń nad Bystrą 1045; g. Magurka 870; Podjałowiec 995; g. Mędralowa 1170; pol. Skalaniec 850; g. Skupniowka 600; g. Surzynówka 800; g. Kwakowa 670; H. Trzebuniaków 1050; g. Wełczon 850; g. Witkówka 650.

\section{L. lapicida (Ach.) Ach. - Bezwapienne piaskowce (maliniaki, głazy, stosy} kamieni); rg. d., rg. g., kos.

5 stan. P: pol. Alacowa 925; g. Rysianka 1300; g. Pilsko 1420. BG: Kościółki 1500. J: g. Lachów Groń nad Bystrą 1045.

L. limosa Ach. - Gleba wśród głazów piaskowcowych; kos.

3 stan. BG: Kościółki 1510; poniżej Diablaka 1610; Diablak 1700.

L. lithophila (Ach.) Ach. - Bezwapienne piaskowce; miejsca widne i suche lub lekko cieniste i nieco wilgotne; rg. d., rg. g., kos.

53 stan. WR: g. Ochodzita 820; g. Zabawa 800; Tomusie 655; H. Rachowiec 910; g. Jaworzyna 985; Obłaz 830; pol. Kołyska 1010; H. Śrubita 1000; Przysłop Połucki 870; g. Wielka Racza 1225; H. Przysłop 940; pol. Głowa 925; H. Muńczoł 1120; pol. Joneczkowe Rycerki 715; pol. Raztoki 750; g. Będoszka Wielka 1100; g. Skalanka 800; g. Oźna 920; g. Magura 1060; Oźna 780, 870; Stawiska 770. P: pot. Boracza 1025; dol. W Kotarnicy 745; poniżej H. Majerkowej 1070; g. Lazy 995; g. Pilsko 1375, 1450; pol. Krawcula 1035; g. Trzy Kopce 1200, 1215; pol. Boruć 795; H. Bieguńska 1160; Sopotnia Wielka 850; H. Malarka 1050; pol. Alacowa 925; g. Czarny Groń 1095; g. Solisko 1180. BG: Cyl 1485, 1515; H. Czarna 1080; Kościółki 1500, 1580; Suchy Potok 1365; m. Kościółkami a Diablakiem 1625; Akademicka Perć 1525; Diablak 1660. J: g. Magurka 880; Podjałowiec 965; poniżej g. Przyborówka 850; H. Trzebuniaków 1040.

L. plana (Lahm in Koerb.) Nyl. - Bezwapienne piaskowce; miejsca suche i widne lub nieco zacienione; pg., rg. d., rg. g., kos.

158 stan. WR: g. Ochodzita 820; Pietraszyna 840; g. Zabawa 760, 800; g. Popręcina 775; Młaki 700; Do Staroni 770; g. Kiczora 680, 700; Tomusie 575; pol. Butorza 910; H. Rachowiec 910; g. Groniczek 830; g. Klimasy 710; g. Skalanka 800; g. Oźna 880, 920, 930; g. Burów Groń 690; g. Hutyrów 670; Stawiska 700; pot. Rycerka 600; Szczytkówka 875; m. g. Jaworzyna i g. Magura 945; g. Jaworzyna 900, 985, 1020; g. Obłaz 830; g. Praszywka Duża 970, 1030; pol. Wyrobniówka 925; g. Muńczoł 1120, 1165; pol. Bułkowa 760; Przysłop Połucki 870; pol. Cerla 1000; pol. Joneczkowe Rycerki 715; pol. Raztoki 750; Pod Raczą 715; H. Przysłop 940; g. Wiertalówka 1020; pot. Dzięboki 770; pol. Kołyska 1010; pol. Majcherowa 1075; Przegibek 1015; g. Wielka Racza 1235; pol. Głowa 925; H. Śrubita 1000. P: Duraje 610; g. Przypór 855; m. g. Kiczora i g. Magura 840; H. Durajka 835; g. Grapa 600; g. Magura 870; Sopotnia Wielka 735; g. Kotarnica 1000, 1010, 1160; g. Łazy 995; p. Palenica 665; H. Majerkowa 1075; dol. Do Jodłowcowej 725; Żabnicka Rzeka 590; pol. Boruć 795; pol. Na Boruć 895; g. Prusów 965, 1000; g. Romanka 1355; g. 
Malarka 1050; g. Baścikówka 810; H. Wieprzska 1060; pol. Budówka 665; pol. Buczynka 880; Kolonia 760; pol. Alacowa 925; H. Szczawina 1115; H. Boracza 785; m. Sznurkami i Dadokami 865; H. Rysianka 1240; las powyżej H. Mędralowej 1320; H. Cebulowa 1270; las powyżej H. Miziowej 1400; H. Skórzacka 1125; H. Bieguńska 1160; H. Lipowska 1130, 1250; g. Jaworzyna pod Pilskiem 1090; H. Słowikowa 1450; g. Trzy Kopce 1200; g. Sucha Góra 920, 1040; H. Redykalna 1080, 1140; pol. Gruszkowa 1000; H. Motykowa 1050; Dziaski 735; pot. Połom 780; g. Bucioryska 795; pot. Z Gawłowskiego 645; g. Okrągła 830, 850, 930; pot. Głęboki 630; g. Długi Groń 880; pol. Krawcula 1035. BG: S stok Diablaka 1650. J: Barankowa 800; g. Biały Wierch 1040; dol. Bystrej 700; Chudziakówka 500; pot. Czerna 480; g. Czerniańska 500; Drwalówka 690; Figury 810; g. Gawronowa 580; pot. Głucha 580; g. Grzechynia 550; dol. Wilkówki 475; Jałowiec 750; g. Jałowiec 1050; Janiki 770; g. Janoszka 720; H. Janoszkowa 1020; m. g. Jaworzyna a g. Szelust 900; pot. Kalinka 540; g. Kamienna 700; H. Kamińskiego 1118; g. Kiczora 900; Kijakowa 810; g. Kiklówka 745; pot. Kolędówka 650; Kolędówka 800; g. Szczyrk 650; Kowaliczki 600; H. Kubalkowa 1100; Kubiasiaki 690; g. Lachów Groń nad Bystrą 1045; g. Magurka 870; pol. Magurka 825; Podjałowiec 995; g. Mędralowa 1170; Opaczne 960; g. Ostra Górka 600; poniżej Przyborówki 850; pol. Skalaniec 900; g. Skupniówka 600; g. Surmiaków Groń 730; pot. Surmiaków Potok 550; g. Surzynówka 800; g. Kwakowa 670; H. Trzebuniaków 1050; g. Wełczon 800, 840, 875; g. Witkówka 650; dol. Zasepnicy 440.

L. pullata (Norm.) Th. Fr. - Kora drzew iglastych (świerki) oraz liściastych (głównie jarzębiny w rg. g.); przeważnie w stanie płonnym; pg. (wyjątkowo); rg. g. 12 stan. WR: pot. Krążelka 520; m. Rycerką a Rajczą 500; pot. Racza 755; g. Wielka Racza 1180, 1200 (z apotecjami). P: g. Lipowska 1320 (z jednym apotecjum). BG: las powyżej H. Czarnej 1140; las poniżej Akademickiej Perci 1340; Sokolica 1350; H. Kralowa 1320, 1395.

L. turgidula Fr. - Murszejące pniaki, wiatrołomy; miejsca cieniste lub widne; rg. d., rg. g.

11 stan. WR: pot. Radecki 700; Kiełbasówka 700; pot. Stasiowa 710; g. Bednarów Beskid 950. P: Jakubowski Potok 605; pol. Bartek 1150; las powyżej H. Wieprzskiej 1175; g. Lipowska 1280; g. Palenica 1340; g. Romanka 1360. BG: las m. Markowymi Szczawinami a przeł. Brona 1310.

Lecidella asema (Nyl.) Knoph \& Hertel [ = Lecidea subincongrua (Nyl.) Hertel] - Bezwapienne piaskowce (skałki i głazy, niekiedy również stosy kamieni) na halach i polanach; miejsca widne i suche; rg. d.

19 stan. WR: g. Rachowiec 950; pot. Danielka 650; pol. Majów 825; Szczytkówka 875; Przysłop Połucki 900; g. Praszywka Duża 940, 980, 1040; g. Abramów 1070; g. Rycerzowa 1150. P: Kolonia 750; g. Abrahamów 780; g. Okrągła 850; pol. Na Boruć 890; pol. Alacowa 925; H. Malarka 1000; g. Kotarnica 1010; H. Jodłowcowa 1200.

L. carpathica Koerb. [= Lecidea carpathica (Koerb.) Szatala] - Bezwapienne piaskowce; miejsca suche i widne; pg., rg. d., rg. g.

55 stan. WR: Rycerka 515; Myto 670; g. Klimasy 710; g. Kiczorka 750; Magurka 850; pol. Kołyska 1010; g. Praszywka Duża 1040; H. Mała Racza 1120; g. Rycerzowa 1170; g. Muńczoł 1120; Szczytkówka 870; g. Będoszka Wielka 1100; g. Łysica 650; Płaskonków 650; pol. Wyrobniówka 900; pot. Danielka 650. P: g. Grojec 610; H. Wieprzska 1060; H. Motykowa 1050; H. Bieguńska 1160, 1200; g. Rysianka 1240; pot. Głębokie 580; g. Okrągła 950; pot. Z Gawłowskiego 645; H. Cudzichowa 1260; g. Magurka 850; g. Przypór 855; pol. Boruć 795; pol. Szczyrbowe Młaki 890; g. Sucha 960; Milówki 700; g. Kotelnica 750; H. Boracza 900; H. Lipowska 1200. BG: H. Czarna 1080; Suchy Potok 1365; Kościółki 1510; Diablak 1650, 1725; H. Kralowa 1395. J: Drwalówka 690; dol. Gołyńki 520; dol. Grzechynki 450; g. Magurka 800, 870; Opaczne 900.

L. elaeochroma (Ach.) Choisy [= Lecidea elaeochroma (Ach.) Ach., L. olivacea (Hoffm.) Massal.] - Kora drzew liściastych rosnących w lasach naturalnych, obok dróg, nad potokami, rzekami; pg., rg. d., wyjątkowo rg. g.

88 stan. WR: m. Wiertniakówką i Obrotem 590; pot. Krążelka 540; Tarliczne 590; g. Trojaki 660; g. Biernatka 700; Karchówka 565; pot. Czadeczka 580; g. Praszywka Duża 970; pot. Cicha 590; g. Muńczoł 
990; Podścigłów 700; g. Jaworzyna 885; pol. Bułkowa 760; Rycerki 655; pot. Urwisko 715; Pętkowka 650; Żebrakówka 800; Słonkówka 625; Skomisko 680; g. Wiertalówka 1065; pol. Ziajowka 850; g. Przysłop 980; pol. Skrzadnita 1105; g. Przysłop Wielki 960; Kołyska 1000; H. Rycerzowa 1100; g. Upłaz 1020; g. Bednarów Beskid 950;“las. Orzeł 1030; rez. Śrubita 950. P: leśniczówka Janikówka 415; dol. Do Jodłowcowej 835; Żabnicka Rzeka 600; H. Malarka 1000; H. Wieprzska 1060; g. Jodłowcowa 1100; pol. Buczynka 880; H. Łyśniowska 1090; pol. Koziorka 800; H. Jodłowcowa 1200; H. Górowa 1150; leśniczówka Glinne 750; pol. Szczyrbowe Młaki 910; pol. Kobyle Młaki 1000; rez. Rysianka 1130; H. Bacmańska 1125; H. Bieguńska 1150; H. Lipowska 1100; Zająców Potok 1000; H. Rysianka 1100; Śmierdzący Potok 1000, 1090; Na Piętrze 835; pot. Kościelec 700, 840; Złatna 600, 610; Potok Jakubowski 600; g. Okrągła 925, 1010; Kotrysia Polana 720; dol. Straceńca 695, 775; g. Długi Groń 840; Polany Pod Soblówką 900. J: Beskidek 1010; Cicha 635; pot. Czerna 430, 580; las Czerniawa 980; Hyrby 670; pot. Głucha 600; g. Jałowiec 1100; H. Kamińskiego 1050; Kępy 550; g. Kiczora 880; przeł. Klekociny 890, 930; pol. Magurka 825; g. Mędralowa 1150; Pindelówka 1000; Podjałowiec 930; Skupniowka 525; pot. Stracony Potok 610; Wełcza 630; dol. Zasepnicy 500.

L. euphorea (Flk.) Hertel [= Lecidea glomerulosa (DC. in Lam. \& DC.) Steud.] - Kora drzew liściastych, głównie rosnących przy drogach lub jako drzewa samotne; pg.

2 stan. P: Żabnicka Rzeka 600. J: pot. Surmiaków Potok 600.

L. stigmatea (Ach.) Hertel \& Leuckert [ = Lecidea stigmatea Ach., L. cinnamomea Hellb., L. micacea (L.) Koerb., L. vulgata A. Zahlbr.] - Wapienie lub bezwapienne piaskowce (skały, głazy, kamienie na halach, polanach i nieużytkach, nad brzegami potoków i rzek); miejsca suche i widne; pg., rg. d., rg. g.

24 stan. WR: Skomisko 680; pol. Wyrobniówka 900, 910; pot. Nieledwianka 460; Rycerka 515; Ochodzita 760; Podścigłów 770; pot. Rycerka 580; pol. Masarka 720; g. Burów Groń 690; g. Łysica 550; pol. Jaworskie 610. P: Sporysz 420; g. Grojec 610; pol. Bugaj 580; pot. Suseński 480; Tokarnia 890; g. Rysianka 1310; g. Abrahamów 700; Zająców Potok 800; g. Skałka 1195. BG: Sokolica 1350. J: pot. Grzechynka 450; Chudziakówka 500; dol. Wilkówki 475; Janiki 770; pot. Kalinka 540; g. Lachów Groń nad Bystrą 1045; Roztoki 620; pol. Skalaniec 850.

Lecidoma demissum (Rutstr.) Gotth. Schneider \& Hertel in Hertel [= Lecidea demissa (Rustr.) Ach.] - Humusowa gleba w szczelinach naturalnych skałek piaskowcowych, wśród piargów i kamieńców; miejsca suche i widne; rg. d., kos. 5 stan. WR: g. Praszywka Duża 1030. BG: Akademicka Perć 1590, 1670; Diablak 1710, 1725.

Lempholemma chalazanellum (Nyl.) A. Zahlbr. - Lekko wapnista gleba między mchami; miejsca suche; rg. d.

2 stan. P: g. Abrahamów 810; g. Skałka 1195.

L. chalazanum (Ach.) B. de Lesd. - Wapnista gleba w miejscach suchych i widnych, np. na warstewce gleby w zagłębieniach muru oporowego nad potokiem; pg.

1 stan. WR: Gardasówka 580.

Lepraria flavescens Clauz. \& Roux - Zacienione, pionowe skałki piaskowcowe o dużej zawartości węglanu wapnia; rg. d.

3 stan. WR: Podścigłów 700; rez. Oszus 950. J: dol. Czernej 500.

L. incana (L.) Ach. [ = L. aeruginosa auct., L. glaucella (Flk.) Nyl.] - Omszała kora drzew liściastych i iglastych, omszałe skały piaskowcowe, butwiejące pniaki, niekiedy gleba; przeważnie miejsca cieniste; pg., rg. d., rg. g.

126 stan. WR: Kasperki 670; g. Syberia 550; pot. Czadeczka 560; g. Sobczakowa Grapa 715; g. Trojaki 615; Krążelka 540; Rycerka 490; Misiorka 700; Madlówka 625; g. Łysica 550; Szczotka 900; dol. Radeckiego 700; g. Jaworzyna 885; H. Muńczoł 1115; Zawodzie 610; dol. Plaskurówki 700; przys. Pętkówka 650; przys. Słonkówka 750; Kolonia 670; Skomisko 680; pol. Ziajówka 850; g. Przysłop Wielki 
985; pol. Skrzadnita 1105; Pod Raczą 715; g. Plaskierówka 1090; Kołyska 1000; dol. Raczy 800; pot. Mała Jaworzyna 775; g. Rycerzowa Wielka 1195; pot. Urwisko 705; g. Wielka Racza 1100, 1210; dol. Śrubita 750, 975; rez. Śrubita 790, 810, 990; rez. Oszus 1010; g. Bednarów Beskid 950, 1050; las Orzeł 980, 1030; g. Bugaj 1050; g. Jaworzyna k. Bugaja 1150. P: Jeleśnia 415; g. Wolentarski Groń 500; leśniczówka Janikówka 415; Trzebinia 425; pot. Suseński 480; pot. Bystra 585; g. Kotarnica 810, 915; las Tajch 750; Sopotnia Mała 700; dol. pod Uszczawnym 670; las Uszczawne 910; przeł. Przysłopy 750, 860; dol. W Kotarnicy 735, 820; dol. W Ciemnym 1170; Żabnicka Rzeka 600; g. Romanka 1200, 1360; H. Wieprzska 1060, 1120; g. Skałka 1140; dol. Buczynki 800; pol. Alacowa 925; Wielka Sopotnia 840; Za Jurkową 880; Sikorczany Potok 700; pol. Koziorka 800; H. Pawlusia 1170; H. Łyśniowska 1190; H. Górowa 1100; pot. Glinna 1165; g. Pilsko 1360; g. Szczawinka 1280; pol. Szczyrbowe Młaki 910; g. Rysianka 1110, 1130; g. Palenica 1340; pol. Między Młaki 1200; pot. Boracza 1025, 1050; g. Boraczy Wierch 1160; H. Bacmańska 1125; H. Bieguńska 1150; H. Lipowska 1100, 1260; g. Lipowska 1310; g. Trzy Kopce 1160; H. Motykowa 1060; Śmierdzący Potok 900, 950, 1090; dol. Nickuliny 670; pot. Połom 780; Szeroki Kamieniec 800; Jakubowski Potok 605, 700; pot. Kościelec 680; Placówka 710; g. Okrągła 850, 925; pot. Głęboki 630, 650; g. Długi Groń 850; Polany Pod Soblówką 900. BG: pot. Marków 1135; las poniżej H. Czarnej 1060; las powyżej H. Czarnej 1260; H. Kralowa 1320. J: g. Sumerówka 565; dol. Zasepnicy 440; Drwalówka 690; g. Ostra Górka 610; dol. Kalinki 540; Opaczne 900; g. Jałowiec 1010; pot. Kolędówka 650; pot. Surmiaków Potok 580; H. Trzebuniaków 1050; H. Kamińskiego 1050; dol. Głucha 600; g. Mędralowa 1150; Pindelówka 1000; las Czerniawa 910.

L. neglecta (Nyl.) Lettau [= Crocynia neglecta (Nyl.) Hue $]$ - Bezwapienne piaskowce (głazy i kamienie), leżące stosami na nieużytkach, polanach, halach, głazowiskach; miejsca widne i suche; pg., rg. d., rg. g., kos.

28 stan. WR: g. Ochodzita 820; Młaki 475; Rycerka Dolna 550; Magura 850; pol. Wyrobniówka 925; H. Muńczoł 1105; H. Mała Racza 1135. P: Na Skale 860; g. Okrągła 930; pol. Gruszkowa 1000; H. Majerkowa 1075; H. Miziowa na Romance 1120; dol. W Ciemnym 1170; g. Pilsko 1450. BG: Potok Suchy 1365; Kościółki 1500, 1580, 1600; m. Kościółkami a Diablakiem 1625; Diablak 1660, 1675, 1710; S stoki Diablaka 1580, 1610. J: powyżej Drwalówka 690; g. Kamienna 710; g. Magurka 870.

L. membranaceum (Dicks.) Vain. [= Crocynia membranacea (Dicks.) A. Zahlbr.] - Bezwapienne piaskowce (skały w miejscach pionowych i cienistych); rg. d. 1 stan. P: g. Boraczy Wierch 1100.

Leproplaca xantholyta (Nyl.) Hue [ = Caloplaca xantholyta (Nyl.) Jatta] - Wapniste piaskowce; miejsca suche, ale przeważnie cieniste, pionowe lub podwieszone; pg., rg. d.

2 stan. WR: rez. Oszus 950. J: m. Grzechynią a Skupniówką 450.

Leptogium lichenoides (L.) A. Zahlbr. - Wapnista gleba między mchami, niekiedy wśród mchów na pniach starych buków; pg., rg. d.

5 stan. WR: las Ku Zimnej Wodzie 800. P: Sporysz 420;g. Grojec 610. J: dol. Zasepnicy 440; Roztoki 620.

Lithographa tesserata (DC.) Nyl. - Kamyki piaskowcowe; miejsca suche i słoneczne; kos.

1 stan. BG: Sokolica 1370.

Lobaria pulmonaria (L.) Hoffm. - Omszałe pnie starych buków, rzadziej jaworów, rosnące w lasach naturalnych; rg. d.

33 stan. WR: rez. Oszus 900; pot. Śrubita 975; g. Muńczoł 990, 1100; rez. Śrubita 1000; las Orzeł 1030; g. Bugaj 1050; g. Plaskierówka 1090; g. Będoszka Wielka 1100; g. Rycerzowa Wielka 1195. P: H. Wieprzska 1040, 1120; las powyżej H. Wieprzskiej 1150; H. Bieguńska 1150; rez. Rysianka 900, 1090, 1120, 1140; H. Lipowska 1100, 1150; H. Jodłowcowa 1110, 1200; H. Łyśniowska 1090, 1190; H. Górowa 1100; pol. Między Młaki 1200. BG: pot. Marków 1135. J: Pindelówka 1000; H. Kamińskiego 1050; g. Mędralowa 1150. 
Lobothalia radiosa $(\mathrm{Hoffm}$.$) Hafellner [=$ Lecanora radiosa $(\mathrm{Hoffm}$.$) Schaer.]$ - Wapienie oraz wapniste piaskowce i zlepieńce (nasłonecznione skałki, głazy nad brzegami potoków i rzek, gołoborza, osuwiska); miejsca suche i widne; pg., rg. d. 6 stan. WR: Rycerka 515; g. Łysica 550. P: Sporysz 420; g. Grojec 610; g. Abrahamów 780.

Lopadium pezizoideum (Ach.) Koerb. - Stopy omszałych pni starych drzew iglastych; rg. g.

1 stan. BG: las poniżej Sokolicy 1230.

Loxospora cismonica (Beltr.) Hafellner [= Haematomma cismonicum Beltr.] - Kora starych jodeł rosnących w naturalnych lasach, głównie nad brzegami potoków; rg. d.

5 stan. P: pot. Straceniec 695; pot. Połom 790; pot. Stara Piła 780; Zająców Potok 840. J: las poniżej przys. Podjałowiec 850 .

L. elatina (Ach.) Massal. [ = Haematomma elatinum (Ach.) Massal.] - Kora starych świerków w miejscach świetlistych; tylko płonne; rg. g., kos.

3 stan. P: H. Mędralowa 1290; g. Lipowska 1310; g. Pilsko 1400.

Megallaria pulverea (Borr.) Hafellner \& E. Schreiner [= Catillaria pulverea (Borr.) Lettau] - Kora starych drzew iglastych (jodły) i liściastych (jawory), zwykle razem z Arthonia mediella; rg. d.

2 stan. WR: pot. Urwisko 760. P: Zająców Potok 1000.

Melanelia disjuncta (Erichs.) Essl. [ = Parmelia disjuncta Erichs.] - Piaskowce (luźne murki, głazy nad potokami); pg., rg. d.

2 stan. J: m. Grzechynią a Skupniówką 450; g. Skupniówka 600.

M. elegantula (A. Zahlbr.) Essl. [= Parmelia elegantula (A. Zahlbr.) Szat.] - Kora drzew liściastych rosnących pojedynczo; pg., rg. d.

2 stan. WR: Raztoki 700 . J: dol. Zasepnicy 380.

M. exasperata (Nyl.) Essl. [= Parmelia aspera Massal.] - Kora drzew liściastych; rg. d.

1 stan. P: Kotrysia Polana 730.

M. exasperatula (Nyl.) Essl. [ = Parmelia exasperatula Nyl.] - Kora przydrożnych drzew liściastych albo rosnących samotnie; pg., rg. d.

25 stan. WR: Rycerka 500; pot. Krążelka 510; Tarliczne 590; Kiczora 610; Zapasieki 660; Kasperki 670; Pławuchowa 520; Kotłówka 600; Kolonia 670; Raztoki 700; Podścigłów 700; Pod Raczą 715; Szczotka 900. P: Jeleśnia 415; Trzebinia 425; Juszczyna 430; Złatna 600, 610; g. Kotarnica 1000. BG: Polichówka 635. J: Koszarawa 590; g. Surzynówka 800; przeł. Klekociny 890; g. Jałowiec 1110.

M. fuliginosa (Fr. ex Duby) Essl. in Egan [ = Parmelia fuliginosa (Fr. ex Duby) Nyl.] - Kora drzew liściastych leśnych, samotnych lub przydrożnych, koło zabudowań, nad potokami i rzekami, niekiedy na podłożu skalnym; pg., rg. d. 106 stan. WR: pot. Czadeczka 500, 530, 545; m. Wełniakówką i Obrotem 590; Tarliczne 590; pot. Krążelka 520; g. Trojaki 615; m. górami Popręcina i Kiczora 685; Karchówka 565; Szpaki 570; Rycerka 500; pot. Z Głębokiego 520; pot. Rycerka 580; Szczotka 900; g. Jaworzyna 900; g. Praszywka Duża 970; pot. Cicha 590; dol. Plaskurówki 700; Podścigłów 700; pol. Bułkowa 760; Pętkówka 650; Skomisko 680; g. Przysłop Mały 960; Smereków Wielki 750; pol. Ziajówka 850; g. Przysłop 980; g. Pleskierówka 1085; g. Będoszka Wielka 1100; Pod Raczą 717; dol. Przegibka 760; g. Rycerzowa Wielka 1195; H. Rycerzowa 1100; g. Upłaz 1020; rez. Śrubita 990; rez. Oszus 1035; g. Bednarów Beskid 940; dol. Śrubita 975; las Orzeł 1030; g. Jaworzyna k. Bugaja 1100. P: leśniczówka Janikówka 415; przeł. Przysłopy 860; Żabnicka Rzeka 600; pol. Na Boruć 890; H, Wieprzska 1060, 1120; H. Miziowa na Romance 1075; g. Jodłowcowa 1100; pol. Buczynka 860; g. Prusów 1000; pol. Alacowa 925 ; H. Łyśniowska 1090; 1190, g. Kotarnica 1000; m. Halami Miziowa i Szczawina 1160; pol. Szczyrbowe Młaki 
910; H. Bacmańska 1125; H. Bieguńska 1150; H. Lipowska 1100; Zająców Potok 1000; H. Rysianka 1100; g. Magurka k. Trzech Kopców 1030; Śmierdzący Potok 950, 1000; Na Piętrze 835; Sułki 665; Placówka 710; dol. Stara Piła 780, 900; pot. Kościelec 700; Złatna 610; Potok Jakubowski 600; g. Okrągła 925; Kotrysia Polana 720; dol. Straceńca 775, 870; g. Długi Groń 840; Polany Pod Soblówką 900. BG: pot. Marków 1135. J: g. Gawronowa 580; g. Drwalowa 580; Pasierbiaki 530; Pytel 600; Skupniówka 525; gajówka W Gawronce 750; dol. Huciska 500; g. Surzynówka 700; Matusy 520; pot. Stracony Potok 600; Boguniówka 525; g. Jałowiec 1100; m. g. Jałowiec a g. Lachów Groń 800; pot. Kolędówka 650; pot. Surmiaków Potok 600; las Czerniawa 980; Wełcza 630; dol. Bystrej 590, 800; pol. Magurka 825; H. Kamińskiego 1050, 1080; przeł. Klekociny 890; dol. Głucha 600; g. Mędralowa 1150.

M. glabra (Schaer.) Essl. [= Parmelia glabra (Schaer.) Nyl.] - Kora drzew liściastych; rg. d.

7 stan. WR: Słonkówka 625; Szczotka 900. P: Złatna 600; Kręcichłosty 740; pol. Koziorka 800; g. Kotarnica 1000. J: Janiki 780.

M. hepatizon (Ach.) Thell [= Cetraria hepatizon (Ach.) Vain.] - Bezwapienne piaskowce (skałki, piargi, głazy); kos.

9 stan. BG: Kościółki 1400, 1500; Diablak 1660, 1675, 1680, 1700, 1710; S stok Diablaka 1580, 1660.

M. laciniatula (Flag. ex Oliv.) Essl. [ = Parmelia laciniatula (Flag. ex Oliv.) A. Zahlbr.] - Kora starych drzew liściastych, najczęściej przydrożnych; rg. d. 4 stan. WR: m. górami Kiczora i Popręcina 685. P: Złatna 610; leśniczówka Glinne 740; g. Kotarnica 1000 .

M. stygia (L.) Essl. [= Parmelia stygia (L.) Ach.] - Bezwapienne piaskowce (głazy); kos.

1 stan. BG: Diablak 1700.

M. subargentifera (Nyl.) Essl. [ = Parmelia verruculifera auct.] Kora drzew liściastych, głównie przydrożnych i rosnących samotnie; pg., rg. d.

15 stan. WR: Nieledwia 480; Pławuchowa 520; pot. Rycerka 580; Zawodzie 610; Słonkówka 625. P: leśniczówka Janikówka 415; Przyłęków 475; Złatna 600; g. Kotarnica 1000. J: Wygoda 420; dol. Czernej 500; Dolinka 620; Wełcza 630; Pytel 650; g. Surzynówka 700.

M. subaurifera (Nyl.) Essl. [ = Parmelia subaurifera Nyl.] - Kora i gałęzie drzew liściastych rosnących w lasach; przeważnie miejsca widne; pg.. rg. d.

21 stan. WR: pot. Czadeczka 500; Kolonia 670; Rycerki 680; pot. Plaskurówka 700; Słonkówka 750; pot. Racza 755; pol. Bułkowa 760; pot. Urwisko 780; ]ebrakówka 800; H. Skrzadnita 1100, 1105; H. Muńczoł 1115. P: Żabnicka Rzeka 500; Jastrzębie 660; pol. Koziorka 800; H. Łyśniowska 1090, 1180; H. Lipowska 1100; H. Wieprzska 1110; H. Bacmańska 1125; rez. Rysianka 1130.

Melaspilea gibberulosa (Ach.) Zw. - Kora starych buków w naturalnych lasach; rg. d.

1 stan. BG: las poniżej H. Czarnej 1040.

Menegazzia terebrata (Ach.) Massal. - Kora starych buków rosnących w naturalnych lasach, rzadziej na olchach i jaworach; rg. d.

27 stan. WR: rez. Śrubita 810, 1090; las Orzeł 920, 965, 985, 1030; g. Majcherowa 950; pot. Racza 975; rez. Oszus 1000, 1075; g. Bednarów Beskid 1050. P: las Tejch 750; rez. Rysianka 900, 1090, 1130; H. Bacmańska 900,1125; H. Lipowska 1100; H. Wieprzska 1120, 1150; H. Bieguńska 1150; H. Łyśniowska 1190. BG: pot. Marków 1135; las poniżej H. Czarnej 1040; las powyżej H. Czarnej 1140. J: H. Kamińskiego 1090; g. Mędralowa 1150.

Micarea denigrata (Fr.) Hedl. [ = Catillaria denigrata (Fr.) Hedl.] - Murszejące drewno (pniaki, dachy szop i szałasów, belki ogrodzeń, poręcze mostów); miejsca widne; pg., rg. d.

23 stan. WR: Nieledwia 530; pot. Krążelka 510; pot. Nieledwianka 440; pot. Plaskurówka 650; g. Jaworzyna 930; pot. Stasiowa 650; Rycerki 645; Rycerka Dolna 540; pot. Danielka 700. P: Figury 575; 
Złatna 610; pot. Z Gawłowskiego 675; g. Kotarnica 1000; H. Redykalna 1060. BG: pot. Jałowiec 620. J: dol. Bystrej 600; Janiczki 520; pot. Grzechynka 570; Nowy Świat 570; Pasierbiaki 530; Roztoki 600; Stryszawa 450; Złabne 680.

M. erratica (Koerb.) Hertel, Rambold \& Pietschm. [= Lecidea erratica Koerb.] - Bezwapienne piaskowce (kamieniste nieużytki, stosy kamieni, luźne murki); rg. d. 8 stan. WR: g. Solański Groń 705. P: Dziaski 735; g. Kubiesówka 790; H. Malarka 1050; H. Cudzichowa 1250. J: dol. Grzechynki 590; g. Lachów Groń nad Bystrą 1045; H. Kubalkowa 1080.

M. lignaria (Ach.) Hedl. [ = Bacidia lignaria (Ach.) Lettau $]$ - Szczątki roślin kwiatowych, obumarłe mchy, naga gleba; miejsca widne; kos.

10 stan. P: g. Pilsko 1400, 1450. BG: Główniak 1570; Kościółki 1580; Akademicka Perć 1555, 1590; Diablak 1660, 1710, 1725; S stoki Diablaka 1600.

M. melaena (Nyl.) Hedl. [ = Bacidia melaena (Nyl.) A. Zahlbr.] - Stopy starych drzew iglastych (świerki) lub obumierające mchy naziemne; rg. d.

2 stan. WR: g. Bednarów Beskid 910. P: pot. Syndzielny 700.

M. peliocarpa (Anzi) Coppins \& R. Sant. [ = Bacidia albicans (Arnold) Lettau, $B$. trisepta (Hellb.) A. Zahlbr.] - Bezwapienne piaskowce, pionowe lub podwieszone, zacienione powierzchnie skałek; niekiedy miejsca widne i suche; pg., rg. d., rg. g., kos. 7 stan. WR: Rycerka 500; Pietraszyna 840. P: g. Grapa 600; Na Piętrze 800; g. Szczawinka 1315; g. Skałka 1195; g. Pilsko 1400.

M. prasina Fr. [= Catillaria prasina (Fr.) Th. Fr.] - Butwiejące, przeważnie rozsypujące się drewno (głównie pniaki) w naturalnych lasach; miejsca cieniste; rg. d. 42 stan. WR: Misiorka 700; pol. Kołyska 920; rez. Śrubita 990; pot. Racza 800; pot. Stasiowa 710; pol. Na Praszywce 825; pot. Mała Jaworzyna 775; pot. Urwisko 730; pot. Pętkówka 740; g. Wiertalówka 980; pol. Majów 805; pot. Danielka 700. P: H. Wieprzska 1210; pot. Sopotnia Wielka 840; dol. Pod Uszczawnym 670; dol. W Kotarnicy 735; dol. W Ciemnym 830; g. Kotarnica 970; pot. Kajdasówka 860; pot. Głęboki 650; Kotrysia Polana 780; Jakubowski Potok 645; pot. Połom 780; g. Okrągła 950; pot. Z Gawłowskiego 740; g. Szczawina 1160; pot. Boracza 700; Korbielów 590; g. Lipowska 1300. J: Topory 700; pot. Czerna 580; S stok g. Jałowiec 1000; Roztoki 700; Siwcówka 600.

M. sylvicola (Flot.) Vězda \& V. Wirth [ = Lecidea sylvicola Flot.] - Bezwapienne piaskowce (głazy i kamienie w naturalnych lasach); miejsca zacienione, lecz suche; rg. d., rg. g.

9 stan. WR: pot. Radecki 710; pot. Przegibek 800; g. Wielka Racza 1100. P: pot. Sopotnia Mała 700; dol. W Kotarnicy 735; Śmierdzący Potok 1010; rez. Rysianka 1090; poniżej H. Bieguńskiej 1150; powyżej pot. Cebula 1270.

Microcalicium arenarium (Hampe ex Massal.) Tibell [= Coniocybopsis arenaria (Hampe ex Massal.) Vain.] - Proszkowata plecha porostu Psilolechia lucida, rosnącego w jamkach luźnych murków i stosów kamieni piaskowcowych; rg. d. 4 stan. WR: g. Rachowiec 900. P: przeł. Przysłopy 860; Polany Koło Soblówki 900. J: dol. Magurki 750.

M. disseminatum (Ach.) Vain. [ = Strongylopsis commixta Vain.] - Kora starych drzew iglastych (jodły); rg. g.

1 stan. BG: las poniżej Sokolicy 1090.

Miriquidica garovaglii (Schaer.) Hertel \& Rambold [= Lecidea aenea (Fr.) Nyl.] - Bezwapienne piaskowce (piargi, głazy, skałki); kos.

10 stan. BG: Akademicka Perć 1610, 1660, 1670; Diablak 1700, 1710, 1725; S stoki Diablaka 1580, 1610, $1660,1675$.

M. leucophaea (Flk. ex Rabenh.) Hertel \& Rambold [= Lecidea leucophaea (Flk. ex Rabenh.) Nyl.] - Piargi, głazy piaskowcowe; kos.

2 stan. BG: Kościółki 1400; Diablak 1660. 
Mycobilimbia berengeriana (Massal.) Hafellner \& V. Wirth $[=$ Lecidea berengeriana (Massal.) Th.Fr.] - Według SuZY (1951) rośnie na Babiej Górze; obecnie nie stwierdzony.

M. hypnorum (Lib.) Kalb \& Hafellner in V. Wirth [= Lecidea sanguineoatra (Wulf.) Ach.] - Omszałe pnie starych buków, również szczątki roślin naczyniowych i obumierające mchy naziemne; rg. d., kos.

4 stan. WR: Zawodzie 610. P: las powyżej H. Wieprzskiej 1130. BG: las powyżej H. Czarnej 1140; Diablak 1660.

M. sabuletorum (Schreb.) Hafellner [= Bacidia sabuletorum (Schreb.) Lettau] - Mchy porastające pnie starych buków; pg., rg. d.

14 stan. WR: rez. Śrubita 990; pol. Skrzadnita 1105; g. Będoszka Wielka 1120. P: H. Górowa 1100; las poniżej H. Bieguńskiej 1150; H. Jodłowcowa 1200. J: Janiczki 500; pot. Zasepnica 460; H. Kamińskiego 1100; g. Mędralowa 1150.

Mycoblastus affinis (Schaer.) Schauer. - Kora starych świerków w borach górnoreglowych, bardzo rzadko na korze starych buków; rg. d., rg. g., kos.

10 stan. P: g. Lipowska 1300; g. Romanka 1365; g. Rysianka 1280, 1290; g. Szczawinka 1200, 1300, 1340; g. Skałka 1250; g. Pilsko 1360. BG: las m. Markowymi Szczawinami a przeł. Brona 1280.

M. fucatus (Stirt.) A. Zahlbr. [= M. sterilis Coppins \& P. James $]$ - Kora starych drzew iglastych (jodły), rzadko liściastych (buki) rosnących nad potokami w wąskich dolinach i innych wilgotnych miejscach; rg. d.

21 stan. WR: las Orzeł 930. P: pot. Bystra 585; Jastrzębie 660; pot. Straceniec 695, 900; pot. Syndzielny 690, 710; pot. Boracza 700; pot. Kościelec 730; Śmierdzący Potok 760; pot. Z Gawłowskiego 770; pot. Stara Piła 780, 870, 900; dol. W Kotarnicy 850; Zająców Potok 910; pot. Glinna 920. BG: poniżej Sokolicy 1090. J: dol. Czernej 580; pot. Stracony Potok 600; Siwcówka 600; Roztoki 700; dol. Magurki 800 .

M. sanguinarius (L.) Norm. - Kora starych świerków, rzadko drzew liściastych i jodeł; rg. d., rg. g., kos.

26 stan. WR: rez. Oszus 900, 1110; g. Bednarów Beskid 1000. P: rez. Rysianka 1120; las powyżej H. Wieprzskiej 1180; g. Szczawinka 1200, 1300, 1315, 1350; g. Lipowska 1260, 1320; g. Palenica 1320; g. Rysianka 1300; las poniżej H. Mędralowej 1290; g. Romanka 1340, 1359, 1365; g. Pilsko 1400. BG: H. Czarna 1290; las m. Markowymi Szczawinami a przet. Brona 1255, 1350; las poniżej Akademickiej Perci 1300; Sokolica 1310; pot. Kiczorka 1360.

Mycocalicium subtile (Pers.) Szat. [= M. minutellum (Ach.) Nadv. $]$ - Murszejące pniaki, okorowane pnie żywych drzew, np. jodeł; miejsca raczej widne; rg. d., rg. g.

30 stan. WR: pot. Czadeczka 610; Wojniaczka 650; pot. Rycerka 650; pot. Danielka 700; g. Hutyrów 680; g. Rachowiec 850; g. Rycerzowa 1100. P: Potok Jakubowski 630; pot. Nickulina 670; pot. Stara Piła 740; pot. Straceniec 750; pot. Kościelec 760; W. Wieprzska 1050; rez. Rysianka 1090; las poniżej H. Bacmańskiej 1125; H. Bieguńska 1150; H. Lipowska 1200; g. Trzy Kopce 1200; g. Rysianka 1300; g. Palenica 1340; las powyżej H. Miziowej 1360. J: Beskidek 1010; dol. Bystrej 600; dol. Gołyńki 520; m. g. Jałowiec a g. Lachów Groń 800; g. Mędralowa 1150; pot. Opaczny 650, 700; dol. Zasepnicy 460; przys. Złabne 680; Roztoki 680.

Neofuscelia loxodes (Nyl.) Essl. [ = Parmelia isidiotyla Nyl.] - Bezwapienne lub słabo wapniste piaskowce (skałki); miejsca suche i widne; rg. d.

1 stan. P: g. Grojec 610.

Nephroma laevigatum Ach. - Według SUZY (1951) rośnie na Babiej Górze; obecnie nie potwierdzony. 
N. parile (Ach.) Ach. - Omszałe pnie starych buków albo porośnięte mchami skałki piaskowcowe; rg. d., rg. g., kos.

3 stan. P: H. Łyśniowska 1190; źródła pot. Glinna 1350. BG: zródła pot. Kiczorka 1395.

N. resupinatum (L.) Ach. - Omszałe pnie starych buków; rg. d. 2 stan. P: H. Łyśniowska 1090; H. Pawlusia 1170.

Normandina pulchella (Borr.) Nyl. - Silnie omszała, spękana kora starych buków zwłaszcza przy górnej granicy rg. d., w piętrze pg. na starych wierzbach. 8 stan. WR: przys. Zawodzie 610; H. Rycerzowa 1100. P: H. Górowa 1100; H. Bacmańska 1125; H. Bieguńska 1150; H. Wieprzska 1150; m. g. Trzy Kopce a H. Rysianką 1200.

Ochrolechia androgyna (Hoffm.) Arnold - Kora (często martwa i omszała) starych drzew liściastych i iglastych, niekiedy kosodrzewina i omszałe skały piaskowcowe; rg. d., rg. g., kos.

73 stan. WR: rez. Śrubita 790, 990; las Orzeł 920, 960, 1030; g. Bednarów Beskid 950; g. Majcherowa 950; Kołyska 1000; rez. Oszus 1035, 1075; g. Bugaj 1050; g. Pleskierówka 1090; H. Muńczoł 1100; g. Rycerzowa 1100, 1120; g. Będoszka Wielka 1100; pol. Skrzadnita 1105; g. Jaworzyna 1150. P: Sucha Góra 920 ; pot. Boracza 1025, 1050; H. Wieprzska 1060, 1120, 1175; H. Łyśniowska 1090; g. Boraczy Wierch 1100, 1240; H. Lipowska 1100, 1200, 1260; g. Jodłowcowa 1100, 1200; g. Rysianka 1100, 1140, 1300; g. Szczawinka 1160, 1300, 1315, 1350; pot. Glinna 1200; H. Mędralowa 1290, 1340; g. Lipowska 1310, 1320; g. Palenica 1320; g. Romanka 1350,1360, 1365; g. Pilsko 1360, 1380, 1400, 1500. BG: las poniżej H. Czarnej 1040; las powyżej H. Czarnej 1140, 1260; m. Markowymi Szczawinami a przeł. Brona 1310; las poniżej Akademickiej Perci 1235, 1300; Akademicka Perć 1660; Kościółki 1600; Sokolica 1230, 1310, 1390; pot. Kiczorka 1360. J: Pindelówka 1000; H. Kamińskiego 1050; g. Mędralowa 1150.

O. arborea (Kreyer) Almb. [= Pertusaria arborea (Kreyer) A. Zahlbr.] -Kora drzew liściastych; rg. d.

8 stan. WR: Pętkówka 650; pot. Rycerka 650; Rycerka Górna 670; Raztoki 700; pot. Urwisko 700; pol. Majcherowa 1075. P: Jakubowski Potok 600; leśniczówka Glinne 750.

O. lactea (L.) Hafellner \& Matzler in Matzler \& Hafellner [= Pertusaria lactea (L.) Arnold] - Bezwapienne piaskowce (skałki, stosy kamieni, luźne murki) albo zacienionych (pionowe ściany skalne); miejsca suche i widne; rg. d., rg. g., kos. 34 stan. WR: g. Hutyrów 670, 700. P: g. Kubiesówka 790; g. Boraczy Wierch 1100; dol. W Ciemnym 1170; g. Skałka 1195; g. Romanka 1200, 1225; g. Pilsko 1400, 1450. BG: Suchy Potok 1365; Kościółki 1400, 1510, 1580; Kępa 1520; m. Kościółkami a Diablakiem 1625; Akademicka Perć 1525, 1555; Sokolica 1350; Diablak 1650, 1660; S stok Diablaka 1580, 1610. J: m. Grzechynią a Skupniówką 450; Chudziakówka 500, 600; g. Czerniańska 500; dol. Czernej 500; dol. Gołyńki 520; pot. Surmiaków Potok 550; Koszarawa 590; g. Kamienna 740.

O. pallescens (L.) Massal. - Kora starych buków, wyjątkowo świerków; rg. d., rg. g.

2 stan. P: pot. Stara Piła 900; H. Mędralowa 1290.

O. subviridis (Hoeg) Erichs. - Kora starych drzew liściastych u nasady pni; rg. d. 2 stan. P: pol. Koziorka 800. J: H. Kamińskiego 1100.

O. turneri (Sm. in Sm. \& Sow.) Hasselrot [= Pertusaria leprarioides auct.] - Kora drzew liściastych lub iglastych (świerki); rg. d., rg. g.

5 stan. WR: pot. Czadeczka 530; Szczotka 900. P: Złatna 600; Placówka 710; g. Szczawinka 1340.

Omphalina hudsoniana (H. S. Jenn.) H. E. Bigelow $[=O$. luteolilacina (Favre) Henderson, Coriscium viride (Ach.) Vain.] - Obumierające mchy naziemne albo humusowa gleba, niekiedy rozkładające się pniaki; kos.

6 stan. P: g. Pilsko 1420, 1450. BG: Kościółki 1480; Akademicka Perć 1570; Diablak 1710; S stoki Diablaka 1610. 
O. umbellifera (L.: Fr.) Quelet $[=O$. ericetorum (Fr.: Fr.) Lange, Botrydina vulgaris Bréb. pp.] - Obumierające mchy, głównie naziemne, albo rozkładające się pniaki; miejsca cieniste i nieco wilgotne; rg. d., rg. g., kos.

12 stan. WR: pot. Butorzy 680; Królowa 760; pot. Plaskurówka 760. P: Jakubowski Potok 605; Dziaski 630; pot. Syndzielny 700; pot. Glinna 1165; g. Szczawinka 1280. BG: las powyżej H. Czarnej 1160; las poniżej Sokolicy 1120; Akademicka Perć 1555; poniżej Diablaka 1610.

Opegrapha dolomitica (Arnold) Koerb. [ $=O$. saxicola auct.] - Pionowe i cieniste skałki wapienne (opuszczone kamieniołomy); pg.

1 stan. P: Sporysz 420.

O. gyrocarpa Flot. - Bewzwapienne, pionowe, cieniste ale suche skały piaskowcowe; prawie zawsze płonne; pg., rg. d., rg. g., kos.

18 stan. WR: przys. Pietraszyna 840; g. Rycerzowa Wielka 1205. P: g. Solisko 1040; dol. W Ciemnym 1095; g. Boraczy Wierch 1100; g. Skałka 1195; g. Romanka 1200, 1225; g. Szczawinka 1315; g. Pilsko 1450. BG: Sokolica 1350; Kościółki 1510, 1580; Akademicka Perć 1525; Diablak 1660, 1710. J: dol. Grzechynki 450.

O. lithyrga Ach. - Bezwapienne skałki (łupki) w cienistych miejscach, np. w mrocznym lesie; rg. d.

1 stan. WR: Las Ku Zimnej Wodzie 800.

O. ochrocheila $\mathrm{Nyl}$. $[=O$. rubescens Sandst.] - Kora starych buków; widne miejsca; rg.d.

2 stan. P: H. Rysianka 1190, 1200.

O. rufescens Pers. - Kora drzew liściastych w naturalnych lasach, rzadziej wolno rosnących; rg. d.

21 stan. WR: Skomisko 680; rez. Śrubita 780; rez. Oszus 950, 1010; g. Bednarów Beskid 940; las Orzeł 975, 985, 1030. P: pot. Kościelec 680; Kotrysia Polana 720; Na Piętrze 835; pot. Stara Piła 900; g. Okrągła 925; rez. Rysianka 980, 1000, 1140; H. Miziowa na Romance 1070. J: dol. Bystrej 800; Kępy 550; dol. Zasepnicy 440 .

O. varia Pers. [ $=$ O. lichenoides Pers., O. pulicaris auct. $]$ - Kora starych drzew liściastych (buki), wyjątkowo iglastych (jodły); rg. d.

15 stan. WR: rez. Śrubita 780, 800; g. Przysłop Wielki 960; g. Bednarów Beskid 1000; g. Bugaj 1050; las Orzeł 1020; Kołyska 1000; rez. Oszus 1075; pol. Skrzadnita 1075. P: g. Rysianka 1075; H. Łyśniowska 1090; H. Lipowska 1100; H. Bacmańska 1125; rez. Rysianka 1140. BG: las poniżej H. Czarnej 1060. J: Pindelówka 1000.

O. viridis Pers. - Kora drzew liściastych nad potokami; cieniste miejsca; rg. d. 2 stan. P: pot. Straceniec 695. J: Siwcówka 570.

O. vulgata Ach. $[=O$. devulgata $\mathrm{Nyl}]-$. Kora drzew iglastych i liściastych; rg. d., rg. g.

42 stan. WR: g. Trojaki 615; Podścigłów 700; dol. Danielki 725; rez. Śrubita 780, 810; Las Ku Zimnej Wodzie 800; g. Bednarów Beskid 900; rez. Oszus 950; dol. Racza 975. P: Jastrzębie 660; pot. Nickulina 670; pot. Straceniec 695; pot. Boracza 700; Placówka 710; pot. Kościelec 735; pot. Z Gawłowskiego 770; Szeroki Kamieniec 790, 800; pot. Połom 790; dol. Buczynki 800; pot. Stara Piła 825; Zająców Potok 840, 910; pot. Bystra 875; dol. W Kotarnicy 850; rez. Rysianka 1020; H. Rysianka 1200. BG: las poniżej H. Czarnej 1040; pot. Marków 1135. J: dol. Czernej 580; dol. Grzechynki 450; dol. Kalinki 700; Kubasy 445; pol.Magurka 850; poniżej g. Magurka 850; pot. Opaczny 700; Roztoki 700; Siwcówka 580; pot. Stracony Potok 600; poniżej g. Witkówka 580; Pytel 550.

O. vulgata Ach. var. subsideralla Nyl. $[=O$. subsiderella (Nyl.) Arnold, $O$. niveoatra (Borr.) Laundon] - Kora jodeł w naturalnych drzewostanach; rg. d. 3 stan. WR: rez. Śrubita 820; rez. Oszus 1000. BG: las poniżej H. Czarnej 1060. 
Ophioparma ventosa $(\mathbf{L}$.) Norm. [ = Haematomma ventosum (L.) Massal.] - Bezwapienne piaskowce (skały, głazy, gołoborza); kos.

4 stan. BG: Kościółki 1580, 1600; Diablak 1660, 1700.

Orphniospora mosigii (Koerb.) Hertel \& Rambold [= Lecidea obscurissima Nyl.]

- Bezwapienne piaskowce (piargi); kos.

1 stan. BG: poniżej Kościółków 1400.

Pachyphiale fagicola (Hepp in Arnold) Kremp. - Kora drzew liściastych (jesiony); pg.

1 stan. P: leśniczówka Janikówka 415.

Pannaria leucophaea (Vahl.) P. M. Jórg. [ = Parmeliella microphylla '(Sm.)' Müll. Arg.] - Omszone, bezwapienne skałki piaskowcowe; miejsca cieniste, ale suche; rg. d.

1 stan. P: polanka powyżej dol. W Ciemnym 1160.

P. pezizoides (Web.) Trevis. - Bezwapienne piaskowce (skałki, głazy) albo omszała gleba; rg. d.

9 stan. WR: pot. Danielka 740. P: pot. Bystra 585; Kosarzyska 620; pot. Buczynka 800; dol. W Kotarnicy 880; pot. Boracza 1025; las poniżej H. Bieguńskiej 1050. BG: Akademicka Perć 1480, 1555.

Parmelia omphalodes (L.) Ach. - Bezwapienne piaskowce (głazy); kos.

1 stan. BG: poniżej Diablaka 1610.

P. saxatilis (L.) Ach. - Kora drzew liściastych i iglastych, również bezwapienne lub słabo wapniste piaskowce; pg., rg. d., rg. g., kos.

117 stan. WR: m. Wełniakówką i Obrotem 590; pot. Czadeczka 500; pot. Krążelka 510, 520; m. g. Kiczora i g. Popręcina 685; Karchówka 565; m. Piekłem i Stajakami 620; g. Rachowiec 800; g. Burów Groń 690; g. Jaworzyna 885; H. Muńczoł 1105; Szczotka 900; g. Kotarz 1110; Słonkówka 625; Kolonia 670; pol. Raztoki 700, 900; Smereków Wielki 750; pol. Skrzadnita 1105; Pod Raczą 715; g. Pleskierówka 1085; g. Będoszka Wielka 1100; Kołyska 1000; g. Wielka Racza 1100, 1180, 1200, 1210; g. Rycerzowa 1180; g. Rycerzowa Wielka 1195; dol. Śrubita 750; pol. Majcherowa 1075; g. Petrykowa 1050; rez. Śrubita 810, 990; rez. Oszus 1150; las Orzeł 960; g. Jaworzyna koło Bugaja 1150. P: g. Grojec 610; leśniczówka Janikówka 415; g. Malarka 1050; dol. W Kotarnicy 880; Żabnicka Rzeka 600; m. Ciścem a Milówką 650; g. Prusów 1000, 1005; H. Kupczykowa 840; H. Miziowa na Romance 1075; H. Wieprzska 1060, 1110; g. Skałka 1140; g. Jodłowcowa 1100; g. Romanka 1340; pol. Koziorka 800; g. Kotarnica 1000; H. Łyśniowska 1190; H. Jodłowcowa 1200; Sucha Góra 750; g. Rysianka 1180, 1320; rez. Rysianka 1130; g. Boraczy Wierch 1160, 1240; H. Bacmańska 1125; H. Bieguńska 1150; H. Lipowska 1100, 1200, 1250, 1310; g. Pilsko 1360, 1385, 1460, 1500; las powyżej H. Mędralowej 1340; g. Szczawinka 1200, 1300, 1315; g. Palenica 1320; g. Sucha Góra 940; g. Lipowska 1320; g. Magurka k. Trzech Kopców 1035; Śmierdzący Potok 1090; Zająców Potok 840; Sułki 665; g. Okrągła 940; dol. Straceńca 870; gajówka Straceniec 775. BG: las powyżej H. Czarnej 1140, 1200; m. Markowymi Szczawinami a przeł. Brona 1225, 1310; Kępa 1520; Diablak 1660, 1710; pot. Kiczorka 1360. J: dol. Zasepnicy 440; dol. Czernej 500; g. Czerniańska 500, 600; Skupniówka 525; g. Gawronowa 580; Roztoki 610; dol. Koszarawy 800; g. Magurka 870; poniżej H. Kamińskiego 1000; Beskidek 1010; H. Kamińskiego 1050; g. Jałowiec 1100, 1110; g. Mędralowa 1150.

P. sulcata Tayl. - Kora drzew liściastych w lasach albo rosnących pojedynczo obok dróg, nad potokami i rzekami, wyjątkowo na podłożu skalnym; pg., rg. d. 83 stan. WR: Kasperki 670; Nieledwia 470, 565; pot. Czadeczka 500, 530, 545; m. przys. Wietniakówka i Obrot 590; Tarliczne 590; pot. Krążelka 500, 520; Karchówka 565; m. g. Kiczora i g. Popręcina 685; Szpaki 570; g. Rachowiec 850; pot. Z Głębokiego 520; Zagajka 625; Pławuchowa 520; g. Łysina 550; pot. Rycerka 580; Szczotka 900; g. Jaworzyna 885, 900; pot. Cicha 590; H. Muńczol 1100, 1115; pot. Plaskurówka 700; Pętkówka 650; Słonkówka 625, 750; Żebrakówka 800; Kolonia 670; pol. Ziajówka 850; pol. Skrzadnita 1105; Pod Raczą 715; g. Pleskierówka 1085; Raztoki 700; pot. Racza 755; H. Rycerzowa 1100; g. Będoszka Wielka 1100; rez. Oszus 1150. P: leśniczówka Janikówka 415; Juszczyna 430; przeł. Przysłopy 860; H. Miziowa na Romance 1075; dol. Do Jodłowcowej 850; g. Kotarnica 1000; g. Prusów 
1000, 1005; Żabnicka Rzeka 600; g. Jodłowcowa 1100; pol. Koziorka 800; H. Pawlusia 1170; H. Łyśniowska 1190; leśniczówka Glinne 750; m. Halami Miziową i Szczawiną 1160; Sucha Góra 750; H. Lipowska 1100; H. Bieguńska 1150; H. Bacmańska 1125; Placówka 710; Złatna 610; Jakubowski Potok 600; gajówka Straceniec 775. J: Semikówka 550; dol. Czernej 430; Hyrby 670; Pasierbiaki 520; Pytel 600; Skupniówka 525; g. Magurka 870; g. Surzynówka 700; Wygoda 420; Kiecka 700; Roztoki 610; Cicha 635; Spikówka 650; g. Jałowiec 1100; pot. Surmiaków Potok 600; Dolinka 520; Wełcza 630; dol. Bystrej 590; Beskidek 1010; przeł. Klekociny 890; H. Kamińskiego 1080, 1100.

Parmeliella triptophylla (Ach.) Müll. Arg. [ = P. corallinoides auct. $]$ - Omszałe pnie starych buków, najczęściej rosnących w przerzedzonych lasach, np. na skraju hal i polan; rg. d.

9 stan. P: Zająców Potok 940; poniżej H. Bacmańskiej 1125; rez. Rysianka 1130; las powyżej H. Wieprzskiej 1150; H. Bieguńska 1150; H. Górowa 1150; g. Trzy Kopce 1160; H. Pawlusia 1170. J: g. Mędralowa 1150.

Parmelina quercina (Willd.) Hale [ = Parmelia quercina (Willd.) Vain.] - Kora i gałęzie drzew liściastych, np. osiki; rg. d.

1 stan. P: Kotrysia Polana 730.

P. tiliacea (Hoffm.) Hale [= Parmelia scortea (Ach.) Ach.] - Kora starych drzew liściastych rosnących pojedynczo, najczęściej obok dróg; pg., rg. d.

10 stan. WR: Milówka 450; Nieledwia 480; Rycerka Dolna 525; Spylowie 550; g. Jaworzyna 885. P: Juszczyna 430; Korbielów Dolny 550. J: Lachowice 430; g. Drwalowa 630; Kobiele 650.

\section{Parmeliopsis ambigua (Wulf.) Nyl. - Kora drzew iglastych i liściastych,} zwłaszcza u nasady pni i przy korzeniach, gałęzie kosodrzewiny, pniaki; pg., rg. d., rg. g., kos.

130 stan. WR: pot. Czadeczka 560; Rupieńka 670; pol. Babczonka 620; g. Trojaki 615; rez. Butorza 620; g. Kiczorki ponad Mytem 800; Zwardoń 670; Orawcowa 775; g. Oźna 880; Stawiska 770; dol. Danielka 725; g. Jaworzyna 930; pol. Juraszkowa 850; H. Muńczoł 1100; Podścigłów 700; pot. Stasiowa 650; Rycerki 645 ; pot. Plaskurówka 700, 710; Żebrakówka 800; pot. Butorzy 680; pol. Cerla 1000, 1055; pot. Pętkówka 715; pol. Raztoki 900; Smereków Wielki 800; pol. Skrzadnita 1105; H. Przysłop 950; Kołyska 1000; pot. Racza 755; g. Mała Racza 815; g. Rycerzowa 1100, 1180; g. Rycerzowa Wielka 1195; pot. Urwisko 705, 750; g. Wielka Racza 1200, 1210; pol. Głowa 815; g. Bednarów Beskid 950; las Orzeł 930, 980; rez. Śrubita 780. P: pot. Bystra 530; g. Kotarnica 920; dol. pod Uszczawnym 725; Latynka 1000; dol. Do Jodłowcowej 725; pot. Romanka 725; H. Wieprzska 1060, 1175; dol. W Ciemnym 900; g. Jodłowcowa 1100; g. Prusów 1000; H. Szczawina 1060; Sikorczany Potok 700; pot. Syndzielny 780; g. Rysianka 1200, 1300, 1320; g. Pilsko 1350, 1360, 1400, 1490, 1500; las powyżej H. Mędralowej 1340; las poniżej H. Mędralowej 1290; g. Palenica 1320, 1340; g. Szczawinka 1315; pol. Między Młaki 1225; H. Miziowa 1220; m. Halami Miziową i Szczawiną 1160; H. Cudzichowa 1175; H. Cukiernicza Wyżnia 860; Turniczka 1380; g. Boraczy Wierch 1160, 1240; H. Bacmańska 1125; H. Bieguńska 1150; g. Lipowska 1320; H. Lipowska 1100; g. Jaworzyna 1025; pol. Sucha Góra 940; m. Halami Lipowską i Bieguńską 1280; g. Trzy Kopce 1080; Śmierdzący Potok 760, 1010, 1090; Zająców Potok 820, 975; pot. Z Gawłowskiego 740, 770; Potok Jakubowski 680; dol. Straceńca 870; g. Wilczy Groń 950; m. polanami Plekońka i Krawcula 1000. BG: las powyżej H. Czarnej 1200; las poniżej Akademickiej Perci 1235, 1340; Sokolica 1370; Cyl 1480; m. Markowymi Szczawinami a przeł. Brona 1310; przeł. Brona 1410; Kościółki 1580; H. Kralowa 1255, 1395; pot. Kiczorka 1395. J: g. Grzechynia 500; dol. Głucha 650; Roztoki 700 g. Magurka 870; las Czerniawa 940; H. Kamińskiego 1050; g. Mędralowa 1150; g. Czerniawa Sucha 1030; Drwalówka 690; g. Jałowiec 1100; m. g. Jałowiec a g. Lachów Groń 800; g. Kamienna 700; poniżej H. Kamińskiego 1000; H. Kubalkowa 1000; dol. Magurki 830; Podksięże 500; g. Skupniówka 650.

P. hyperopta (Ach.) Arnold - Kora drzew iglastych (głównie świerki w wyższych położeniach), gałęzie kosodrzewiny oraz pniaki; rg. d., rg. g., kos.

39 stan. WR: rez. Butorza 620; Las Ku Zimnej Wodzie 800; H. Muńczoł 1125; g. Wielka Racza 1235. P: Zająców Potok 820; H. Szczawina 1060; g. Trzy Kopce 1080; H. Lipowska 1100, 1280; g. Boraczy Wierch 
1160; H. Cudzichowa 1175; H. Wieprzska 1180; H. Rysianka 1200; H. Miziowa 1220; g. Lipowska 1260, 1320, 1325; H. Mędralowa 1290, 1320; g. Szczawinka 1300, 1315, 1350; g. Palenica 1320, 1340; g. Rysianka 1320; g. Romanka 1365; Turniczka 1380; g. Pilsko 1360, 1400. BG: las powyżej H. Czarnej 1200, 1260; las poniżej Akademickiej Perci 1340; m. Markowymi Szczawinami a przeł. Brona 1310; Kościółki 1580; pot. Kiczorka 1395. J: m. g. Kamienna a g. Surzynówka 700; Podjałowiec 800; H. Kubalkowa 1000; g. Jałowiec 1100.

Peltigera aphthosa (L.) Willd. - Gleba wśród mchów; kos.

1 stan. BG: Diablak 1710.

P. canina (L.) Willd. - Gleba i omszałe skały nad potokami, po przydrożach; miejsca cieniste; pg., rg. d., rg. g.

13 stan. WR: Staronie 770; Zawodzie 610; pot. Plaskurówka 680; pot. Rycerka 600; g. Klin 850; H. Muńczoł 1100; pol. Skrzadnita 1105. P: Fułatów Potok 480; pot. Suchy 630; Sikorczany Potok 735; Dziaski 800; g. Romanka 1225.

P. degenii Gyeln. [ = P. nitens (Anders) Gyeln.] - Omszałe pnie starych buków rosnących w naturalnych lasach, zwykle u nasady pni i przy korzeniach; rg. d. 13 stan. WR: g. Trojaki 650; pot. Danielka 700 (z apotecjami); pot. Plaskurówka 715; rez. Śrubita 810; pol. Głowa 950; las Orzeł 1030 (z apotecjami); g. Przegibek. P: Kosarzyska 620; pot. Sopotnia Mała 700; Szeroki Kamieniec 900; las powyżej H. Wieprzskiej 1120; pol. Między Młaki 1200. BG: m. Marków Potok a H. Czarna 1105.

P. didactyla (With.) Laundon $[=P$. spuria (Ach.) DC., P. hazslinszkyi Gyeln., $P$. erumpens (Nyl.) Vain.] - Gliniasta lub piaszczysta gleba, np. skarpy dróg polnych; pg., rg. d.

5 stan. WR: Nieledwia 505; Wierch Czadeczka 680; Zawodzie 680; g. Będoszka Wielka 1100. P: pot. Z Gawłowkiego 675 .

P. horizontalis (Huds.) Baumg. - Omszone piaskowce, glebạ na nieużytkach; pg., rg. d.

15 stan. WR: g. Kiczorka 590; Rycerka 500; pot. Rycerka 580; Rycerki 655; pot. Smerekówka Mała 700; leśniczówka Pod Raczą 715; pot. Danielka 770; g. Praszywka Duża 930. P: Sporysz 420; pot. Suchy 630; las Tajch 750; g. Kubiesówka 790; Zapolanka 900; H. Górowa 1000; H. Pawlusia 1170.

P. lepidophora (Nyl. ex Vain.) Bitt. - Mury oporowe nad potokami, we wgłębieniach w miejscach spajania kamieni, na warstewce gleby; rg. d.

1 stan. WR: pot. Rycerka 580.

P. leucophlebia (Nyl.) Gyeln. - Warstwa zwietrzeliny na skałkach piaskowcowych nad potokami; pg.

1 stan. J: Janiczki 540.

P. malacea (Ach.) Funck - Według SuZY (1951) rośnie na Babiej Górze; obecnie nie potwierdzony.

P. polydactyla (Neck.) Hoffm. - Omszałe skały piaskowcowe, głazy albo stopy pni starych drzew liściastych; pg., rg. d.

12 stan. WR: m. Rycerką a Rajczą 490; przeł. Madejka 665; Rupieńka 670; Potok Wielki 670; g. Popręcina 785; Rycerki 655; g. Klin 850. P: Fułatów Potok 460; pot. Bystra 640; pot. Wojtasi 640; pot. Głęboki 690; las Tajch 750 .

P. praetextata (Flk. ex Sommerf.) Zopf $[=P$. subcanina Gyeln. $]$ - Omszałe skały i głazy piaskowcowe oraz stopy pni starych drzew w naturalnych lasach; rg. d. 15 stan. WR: Zwardoń 670; pot. Smerekówka Wielka 700 (z apotecjami); las Orzeł 1020, 1030; g. Rycerzowa Wielka 1195. P: pot. Z Gawłowskiego 675; las Tajch 750; Na Piętrze 835; pot. Boracza 1025; las poniżej H. Lipowskiej 1100; rez. Rysianka 1025, 1140; las poniżej H. Bacmańskiej 1125; g. Trzy Kopce 1160; H. Łyśniowska 1190. BG: las powyżej H. Czarnej 1140. 
P. rufescens (Weis.) Humb. - Omszałe skałki, głazy, murki oporowe nad potokami, głównie gleba na nieużytkach; pg. rg. d.

12 stan. WR: Wierch Czadeczka 680; przys. Myto 600; pot. Dzięboki 580; pot. Rycerka 600; Rycerki 600; pot. Plaskurówka 680; Raztoki 700; Graniczne 785. P: Fułatów Potok 430; pot. Z Gawłowskiego 640; g. Okrągła 890.

P. venosa (L.) Hoffm. - Według SuZY (1951) rośnie na Babiej Górze; obecnie nie potwierdzony.

Pertusaria albescens (Huds.) Choisy \& Werner in Werner var. albescens $[=P$. discoidea (Pers.) Malme] - Kora drzew liściastych leśnych i koło dróg, po sadach, obok zabudowań, wyjątkowo na skałach; pg., rg. d., rg. g.

35 stan. WR: Kasperki 670; Pętkówka 650; Kolonia 670; Skomisko 680; Pod Raczą 715; pol. Bułkowa 760; g. Jaworzyna 885; Szczotka 900; g. Muńczoł 990, 1115; g. Bugaj 1050; g. Będoszka Wielka 1100, 1120. P: Przyłęków 475; g. Grojec 610; Żabnicka Rzeka 600; Złatna 610; Bura Polana 665; g. Kotarnica 1000; H. Górowa 1100; H. Łyśniowska 1190; H. Pawlusia 1190. J: dol. Zasepnicy 460; Pytel 550; Roztoki 610; Wełcza 630; Dolinka 630; g. Drwalowa 680; dol. Cicha 700; dol. Koszarawy 800; przel. Klekociny 890; Opaczne 940; Beskidek 1010; H. Kamińskiego 1080, 1100; g. Jałowiec 1110.

P. albescens (Huds.) Choisy \& Werner in Werner var. globulifera (Turn.) Poelt [= P. globulifera (Turn.) Massal.] - Kora drzew liściastych; rg. d.

7 stan. WR: Rycerki 645; pol. Bułkowa 670. P: Bura Polana 665; Placówka 710; g. Kotarnica 1000; H. Łyśniowska 1190. J: dol. Grzechynki 575 .

P. alpina Hepp. ex H. E. Ahles - Kora starych buków rosnących w lasach naturalnych; rg. d.

2 stan. WR: g. Trojaki 650; g. Upłaz 1020.

P. amara (Ach.) Nyl. - Kora drzew liściatych, rzadziej iglastych, wyjątkowo bazwapienne piaskowce; pg., rg. d., rg. g.

99 stan. WR: pot. Czadeczka 545; m. Wełniakówką a Obrotem 590; pot. Krążelka 520; g. Trojaki 615; m. g. Kiczora i g. Popręcina 685; Rycerka 515; g. Rachowiec 850; g. Łysica 550; Szczotka 900; g. Jaworzyna 900; pot. Cicha 590; g. Muńczoł 990, 1100; pol. Bułkowa 760; Pętkówka 650; Przysłop Połucki 900; Żebrakówka 800; pol. Ziajówka 850; pol. Skrzadnita 1100, 1105; Pod Raczą 715; g. Pleskierówka 1085; g. Będoszka Wielka 1100; Raztoki 700; pot. Racza 755; g. Rycerzowa Wielka 1195; H. Rycerzowa 1100; g. Wielka Racza 1100; g. Rycerzowa 1150; rez. Śrubita 990; rez. Oszus 1035, 1150; dol. Śrubita 975; las Orzeł 980, 1030; g. Jaworzyna k. Bugaja 1150; pot. Urwisko 780. P: leśniczówka Janikówka 415; g. Kotarnica 1000; H. Miziowa na Romance 1075; g. Romanka 1360; Żabnicka Rzeka 600; g. Prusów 1005; H. Wieprzska 1060, 1150; g. Jodłowcowa 1100; pol. Alacowa 925; H. Łyśniowska 1095; pol. Koziorka 800; pot. Syndzielny 710; H. Jodłowcowa 1200; g. Skałka 1195; las powyżej H. Mędralowej 1340; pol. Szczyrbowe Młaki 910; pol. Kobyle Młaki 1000; g. Rysianka 1200, 1300; H. Bacmańska 1125; H. Bieguńska 1150; H. Lipowska 1100; pot. Bystra 1100; H. Motykowa 1050; dol. Z Wideł 950; g. Magurka k. Trzech Kopców 1035; Śmierdzący Potok 950; Zająców Potok 840; Na Piętrze 835; Złotnice 925; pot. Połom 790; Sułki 665; Placówka 710; pot. Kościelec 700, 730; g. Okrągła 925, 1010; Złatna 610; Potok Jakubowski 600. BG: pot. Marków 1135; las powyżej H. Czarnej 1140; m. Markowymi Szczawinami a przel. Brona 1225; pot. Kiczorka 1360. J: Pasierbiaki 520; dol. Czernej 530; pot. Surmiaków Potok 550; dol. Głucha 600; pot. Stracony Potok 600; Kowaliczki 600; Złabne 680; dol. Cicha 700; Podjałowiec 930; H. Kubalkowa 1000; Beskidek 1010; H. Kamińskiego 1050, 1080; g. Jałowiec 1100; g. Mędralowa 1150.

P. aspergilla (Ach.) Laundon $[=P$. leucosora auct. $]$ - Bezwapienne, pionowe i zacienione skały piaskowcowe; rg. d., kos.

2 stan. P: g. Boraczy Wierch 1100. BG: Kępa 1520.

P. coccodes (Ach.) Nyl. var. coccodes - Kora starych drzew liściastych (głównie buki, rzadziej dęby), wyjątkowo iglastych (świerki); rg. d., rg. g. 5 stan. WR: g. Muńczoł 1100. P: Bura Polana 650; rez. Rysianka 1100; g. Palenica 1320. J: dol. Glucha 630. 
P. coccodes (Ach.) Nyl. var. phymatodes (Ach.) Almb. $[=P$. phymatodes (Ach.) Erichs.] - Kora drzew przydrożnych; rg. d.

3 stan. WR: Kasperki 670; Raztoki 700. J: dol. Zasepnicy 460.

P. corallina (L.) Arnold - Bezwapienne piaskowce, skałki, głazy; kos.

15 stan. P: g. Pilsko 1420. BG: Akademicka Perć 1525, 1555, 1610, 1660, 1670; Diablak 1650, 1660, 1675, 1700, 1710; S stoki Diablaka 1600, 1610.

Pertusaria coronata (Ach.) Th. Fr. [ $=$ P. isidiifera Erichs. $]$ - Kora starych drzew liściastych rosnących w naturalnych lasach; rg. d.

57 stan. WR: g. Trojaki 615; g. Rachowiec 850; pot. Cicha 590; Pętkówka 650; pol. Bułkowa 760; rez. Śrubita 810, 850, 975, 1000; g. Majcherowa 950; las Orzeł 980, 1020; g. Muńczoł 960, 1100; g. Bednarów Beskid 1000; Kołyska 1000; rez. Oszus 1035, 1150; g. Bugaj 1050; g. Pleskierówka 1090; g. Będoszka Wielka 1100; g. Rycerzowa Wielka 1100, 1195; pol. Skrzadnita 1105. P: g. Grojec 610; Żabnicka Rzeka 600; Sułki 665; pol. Koziorka 800; g. Długi Groń 850; pot. Stara Piła 900; pol. Alacowa 925; g. Okrągła 925; pol. Kobyle Młaki 1000; g. Kotarnica 1000; g. Prusów 1005; H. Wieprzska 1060, 1110, 1150; H. Łyśniowska 1090, 1190; H. Lipowska 1100; g. Jodłowcowa 1100, 1200; H. Bacmańska 1125; rez. Rysianka 1130, 1140; H. Bieguńska 1150; g. Szczawina 1160. BG: las poniżej H. Czarnej 1040. J: Podksięże 600; dol. Głucha 630; Opaczne 940; Beskidek 1000; Pindelówka 1000; H. Trzebuniaków 1030; H. Kamińskiego 1050.

P. flavicans Lamy - Bezwapienne piaskowce, na powierzchniach pionowych lub podwieszonych; miejsca cieniste; rg. d.

1 stan. P: g. Skałka 1195.

P. hemisphaerica (Flk.) Erichs. - Kora starych drzew liściastych, wyjątkowo iglastych; rg. d.

27 stan. WR: g. Trojaki 615; Raztoki 700; g. Przysłop Mały 960; las Orzeł 975, 1030; rez. Oszus 1000, 1150; g. Bednarów Beskid 1050; g. Petrykowa 1050; g. Będoszka Wielka 1100, 1120; g. Rycerzowa Wielka 1100, 1195. P: pot. Połom 790; pol. Koziorka 800; g. Długi Groń 850; pot. Stara Piła 900; Sucha Góra 920; g. Prusów 1005; H. Miziowa na Romance 1075; H. Lipowska 1100; g. Jodłowcowa 1100, 1200; H. Wieprzska 1120; H. Bacmańska 1125; H. Łyśniowska 1190. J: Pindelówka 1000; H. Kamińskiego 1110.

P. leioplaca DC. in Lam. \& DC. - Kora drzew liściastych; rg. d. 6 stan. WR: Rycerki 650; g. Bednarów Beskid 1000; las. Orzeł 1030. P: pot. Straceniec 695; Polany Pod Soblówką 900. J: Głuchaczki 980.

P. cf. leioterella Erichs. [ $=$ P. pertusa var. leiotera (Nyl.) A. Zahlbr.] - Kora starych drzew liściastych (buki); rg. d.

1 stan. P: pot. Straceniec 695.

P. pertusa (L.) Tuck. - Kora drzew liściastych (głównie stare buki, rzadziej jarzębiny, jawory) w naturalnych lasach; rg. d.

35 stan. WR: g. Trojaki 650; Podścigłów 700; rez. Śrubita 810; las Orzeł 920; g. Bednarów Beskid 940, 1000; g. Majcherowa 950; Kołyska 1000; g. Jaworzyna k. Bugaja 1100; pol. Skrzadnita 1105; g. Rycerzowa Wielka 1120, 1195; g. Muńczoł 1150. P: Złatna 600; pol. Koziorka 800; Na Piętrze 835; g. Długi Groń 840; pol. Buczynka 860; Polany Pod Soblówką 900; pot. Stara Piła 900, 1000; H. Miziowa na Romance 1075; H. Łyśniowska 1090, 1190; H. Lipowska 1100; H. Wieprzska 1120; H. Bacmańska 1125; rez. Rysianka 1130; H. Bieguńska 1150; H. Jodłowcowa 1200. BG: pot. Marków 1135; las poniżej H. Czarnej 1060. J: H. Kamińskiego 1050, 1100; g. Mędralowa 1150.

Phaeographis dendritica (Ach.) Müll. Arg. - Według STEINA (1872) gatunek pospolity na Babiej Górze; obecnie nie potwierdzony.

Phaeophyscia endophoenicea (Harm.) Moberg [ = Physcia endophoenicea $($ Harm.) Santha] Kora drzew liściastych wolno rosnących (stare omszałe buki, jesiony, klony); rg. d. 
12 stan. WR: g. Trojaki 615; Pętkówka 650; g. Jaworzyna 900; H. Rycerzowa 1100. P: g. Kotarnica 1000; g. Jodłowcowa 1100; H. Wieprzska 1110; H. Pawlusia 1180. J: Janiczki 500; Przyborówka 860; Podjałowiec 930; H. Kamińskiego 1100.

Ph. hirsuta (Mereschk.) Moberg [= Physcia hirsuta Mereschk., P. labrata Mereschk.] - Kora przydrożnych drzew liściastych (topole); pg.

1 stan. P: Kupcanki 475.

Ph. nigricans (Flk.) Moberg [= Physcia nigricans (Flk.) Stizenb. $]$ - Kora drzew liściastych, przeważnie przydrożnych oraz skały wapienne, podłoże betonowe; pg., rg. d.

4 stan. WR: Pietraszyna 840. P: Przyłęków 475; g. Grojec 610; Złatna 600.

Ph. orbicularis (Neck.) Moberg [ = Physcia orbicularis (Neck.) Poetsch in Poetsch \& Schied.] - Kora drzew liściastych przydrożnych oraz wolno rosnących (topole, wierzby, jarzębiny, jesiony, kasztanowce, lipy), skały wapienne, wapniste lub podłoże betonowe; pg., rg. d.

30 stan. WR: Nieledwianka 460; Rajcza 500; Tarliczne 590; Pławuchowa 520; Rycerka Dolna 525; pol. Butorowe Grapy 540; Słonkówka 625; Kolonia 670; g. Jaworzyna 885. P: Jeleśnia 415; Sporysz 420, 425; Juszczyna 430, 450; Przyłęków 475; Krzyżowa 520; Korbielów 550; Złatna 610; Sopotnia Wielka 620; Cisiec 650; Kamienna 650. BG: pot. Jałowiec 635. J: dol. Zasepnicy 380; Głuszki 400; pot. Surmiaków Potok 550; Wełcza 630; Kiecka 700; dol. Cicha 700; Spyrki 700; g. Surzynówka 700; g. Wełczon 800.

Ph. sciastra (Ach.) Moberg [= Physcia sciastra (Ach.) Du Rietz $]$ - Lekko wapniste piaskowce, wapienie, niekiedy podłoże betonowe; miejsca suche i widne; pg., rg. d.

6 stan. WR: Rycerka 520; Zwardoń 660; g. Ochodzita 760. P: Sporysz 420. J: g. Czerniańska 550; Roztoki 680.

Phlyctis argena (Spreng.) Flot.- Kora drzew liściastych; pg., rg. d.

82 stan. WR: pot. Krążelka 520; Kotłówka 600; Kiczora 610; m. przys. Kasperki a Szczotka 900; g. Praszywka Duża 970; H. Muńczoł 1115; Podścigłów 700; Pętkówka 650; Słonkówka 750; Kolonia 670; g. Przysłop Mały 960; g. Przysłop 980; pol. Skrzadnita 1105; Pod Raczą 715; g. Pleskierówka 1090; H. Przysłop 950; Raztoki 700; pot. Racza 755; g. Rycerzowa Wielka 1195; Przegibek 1020; g. Rycerzowa 1120; las Orzeł 1030; rez. Oszus 1010. P: leśniczówka Janikówka 415; Juszczyna 430; H. Miziowa na Romance 1075; dol. Do Jodłowcowej 850; Żabnicka Rzeka 600; H. Wieprzska 1120; g. Jodłowcowa 1100; pot. Boracza 700; pol. Koziorka 800; H. Jodłowcowa 1200; las Tajch 750; H. Pawlusia 1170; H. Łyśniowska 1190; pol. Szczyrbowe Młaki 1000; pol. Kobyle Młaki 1000; rez. Rysianka 1130; H. Bacmańska 1125; H. Bieguńska 1150; H. Lipowska 1100; H. Rysianka 1100; g. Magura k. Trzech Kopców 1035; Na Piętrze 835; Sułki 665; Placówka 710 (z apotecjami); Bura Polana 665; Złatna 600; Potok Jakubowski 600; pot. Kościelec 840; g. Okrągła 925, 1010; dol. Straceńca 870. J: dol. Zasepnicy 440; Hyrby 670; dol. Czernej 430; Pytel 600; Skupniówka 525; Spyrki 700; pot. Stracony Potok 600; dol. Gołyńki 500; dol. Kalinki 540; Kępy 550; Roztoki 610; Cicha 635; las Czerniawa 980; Dolinka 580; Łabędzie 600; H. Trzebuniaków 1030; pol. Magurka 825; dol. Bystrej 800; przeł. Klekociny 890; Podjałowiec 930; dol. Głucha 600; H. Kamińskiego 1100.

Physcia adscendens (Fr.) Oliv. - Kora liściastych drzew przydrożnych, niekiedy podłoże skalne i betonowe; pg., rg. d.

36 stan. WR: przys. Szpaki 570; Tarliczne 590; Pławuchowa 520; Ujsoły 530; pol. Butorowe Grapy 540; g. Łysica 550; Rycerki 620; Słonkówka 625; Pętkówka 650; pot. Radecki 670; Kolonia 670; pot. Plaskurówka 700; pol. Bułkowa 760; g. Jaworzyna 885, 900. P: Cięcina 445; pot. Nickulina 520; Żabnicka Rzeka 600; Złatna 610; Sopotnia Wielka 620; Cisiec 650; Placówka 710; g. Kotarnica 1000; H. Pawlusia 1190. BG: pot. Jałowiec 635. J: Wygoda 420; m. Grzechynią a Stryszawą 450; dol. Czernej 500; Skupniówka 520; Wełcza 630; g. Drwalowa 680; Spyrki 700; dol. Cicha 700; Kiecka 700. 


\section{Ph. aipolia (Ehrh. ex Humb.) Fürnr. - Kora liściastych drzew przydrożnych; pg.,}

rg. d.

16 stan. WR: Nieledwia 565; Kiczora 610; Piekło 620; Pławuchowa 520; Słonkówka 625; g. Jaworzyna 885. P: Przyłęków 465; Złatna 600, 610; Kotrysia Polana 730; g. Kotarnica 1000. BG: pot. Jałowiec 635. J: Głuszki 400; Łabędzie 620; Drwalówka 680; dol. Cicha 700.

Ph. caesia (Hoffm.) Fürnr. - Wapienie, wapniste, niekiedy również bezwapienne piaskowce; miejsca suche i widne; pg., rg. d.

23 stan. WR: Rycerka 515; Zwardoń 660; Myto 675; g. Ochodzita 760; Pietraszyna 840; g. Łysica 550. P: Sporysz 390, 420; g. Grapa Żar 430; g. Gojec 610; pot. Bystrzanka 480; g. Abrahamów 700; dol. W Ciemnym 1170. J: dol. Zasepnicy 440; dol. Grzechynki 450; m. Grzechynią a Skupniówką 450; dol. Kalinki 540; pot. Surmiaków Potok 550; dol. Głucha 580; g. Lachów Groń nad Skawicą 600; Roztoki 680; Baranówka 700; g. Wełczon 860 .

Ph. dubia (Hoffm.) Lettau [= Ph. teretiuscula (Ach.) Lynge] - Bezwapienne lub nieco wapniste piaskowce (skałki, stosy kamieni, omszałe głazy), kora drzew liściastych, głównie przydrożnych; pg., rg. d.

21 stan. WR: Pławuchowa 520. P: Trzebinia 425; Węgierska Górka 425 (z apotecjami); g. Grojec 610; Milówki 700; pol. Na Boruć 890. J: dol. Zasepnicy 380; Głuszki 400; Grzechynia 400; Wygoda 420; Jarliki 500; dol. Głucha 580; Koszarawa 590; Porębscy 600, 700; Łabędzie 620; Dolinka 620; Spikówka 650; dol. Cicha 700; Bartoszki 700; powyżej Kolędówki 850; g. Witkówka 650.

Ph. stellaris (L.) Nyl. - Kora drzew liściastych, przeważnie przydrożnych i samotnie rosnących; pg., rg. d.

16 stan. WR: Nieledwia 490; Szpaki 570; Wełniakówka 520; Pławuchowa 520; Ujsoły 530; Spylowie 550; Słonkówka 625. P: Sporysz 425; Juszczyna 450; g. Kępa 500; Złatna 600; Cisiec 650. J: Koszarawa 590; Polanki Pierglesowe 680; dol. Cicha 700; Surzynówka 700.

Ph. tenella (Scop.) DC. in Lam. \& DC. - Kora drzew liściastych, głównie przydrożnych, rosnących samotnie, nad potokami i rzekami; pg., rg. d.

27 stan. WR: Sucha Nieledwianka 480 (z apotecjami); pot. Krążelka 510; Karchówka 565; Piekło 600; Nieledwia 665; Spylowie 550; pot. Rycerka 580; dol. Cicha 590; Rycerki 620; Skomisko 680; Raztoki 700; Podścigłów 700; pot. Racza 755; g. Jaworzyna 885. P: Kupcanki 475; Złatna 600; Żabnicka Rzeka 600; Placówka 710. J: Wygoda 420; dol. Czernej 500; Koszarawa 590; dol. Bystrej 600; g. Drwalowa 610; Wełcza 630; Pytel 650.

Ph. tribacia (Ach.) Nyl. - Kora drzew liściastych; rg. d.

1 stan. WR: Kolonia 670.

Physconia distorta (With.) Laundon [= Physcia pulverulenta ('Hoffm.') Frnr.] - Kora drzew liściastych, głównie przydrożnych i pojedynczo rosnących; pg., rg. d. 26 stan. WR: Karchówka 565; Piekło 600; Kiczora 610; Obrot 615; pot. Rycerka 580; Zawodzie 610; Pętkówka 650; g. Jaworzyna 885; Szczotka 890. P: leśniczówka Janikówka 415; Jeleśnia 415; Korbielów Dolny 550; Złatna 600, 610; Żabnicka Rzeka 600; g. Kotarnica 1000. J: Głuszki 400; Wygoda 420; dol. Czernej 430; Koszarawa 590; Kudzie 620; Wełcza 630; Spikówka 650; g. Drwalowa 680; Kiecka 700; dol. Cicha 700; g. Wełczon 800.

Ph. enteroxantha (Nyl.) Poelt [= Physcia enteroxantha Nyl. $]$ - Kora drzew liściastych, głównie przydrożnych i samotnie rosnących; pg., rg. d.

17 stan. WR: Nieledwia 480; pot. Z Głębokiego 520; Piekło 600; Obrot 615; Pławuchowa 520; Rycerka Dolna 525; pot. Rycerka 580; Zawodzie 610; Pętkówka 650; g. Jaworzyna 885. P: Juszczyna 430; Złatna 600; g. Kotarnica 1000. J: Koszarawa 590, 610; Spikówka 650; Hyrby 680.

Ph. grisea (Lam.) Poelt [= Physcia grisea $($ Lam.) A. Zahlbr.] - Kora drzew liściastych, głównie przydrożnych, np. wierzb; pg.

2 stan. WR: Ujsoły 530. J: Stryszawa 500. 
Ph. perisidiosa (Erichs.) Moberg [= Physcia farrea auct. $]$ - Kora drzew liściastych samotnie rosnących lub przydrożnych (jesiony, dęby, wierzby); rg. d. 6 stan. WR: Obrot 615; Kolonia 670; Szczotka 900. P: Złatna 610. J: Pytel 650; g. Drwalowa 680.

Placynthiella icmalea (Ach.) Coppins \& P. James - Humusowa gleba, rozkładające się drewno; rg. d.

1 stan. WR: dol. Danielka 855 (gatunek znacznie częstszy, ale nie uwzględniony podczas badań).

P. oligotropha (Laundon) Coppis \& P. James [= Lecidea uliginosa sensu Vain.] - Torfiasta gleba; miejsca suche i widne; pg., rg. d., rg. g., kos.

14 stan. WR: g. Kiczorka 590; g. Rachowiec 900; g. Praszywka Duża 950, 1040; m. pol. Pietrówka a g. Przegibek 1025. P: g. Prusów 1000; m. pot. Śmierdzącym i Zająców 1025; H. Majerkowa 1075; g. Trzy Kopce 1200; g. Pilsko 1400, 1425, 1535. J: dol. Kalinki 540; Opaczne 900.

P. uliginosa (Schrad.) Coppins \& P. James [= Lecidea humosa (Hoffm.) Leight.] - Naga, torfiasta albo próchniczna gleba, murszejące drewno, niekiedy również nasadowe części żywych drzew; pg., rg. d., rg. g., kos.

82 stan. WR: pot. Czadeczka 560; g. Kiczorka 590, 725, 780; Zapasieki 660; pol. Babczonka 620; Mlaki 745; pot. Krążelka 510; Do Staroni 770; g. Hutyrów 740; g. Łysica 550; dol. Danielki 700; Obłaz 830; H. Muńczoł 1125; pot. Stasiowa 650; pot. Plaskurówka 680, 710, 735; Rycerki 620, 640; pol. Raztoka 855; pol. Masarka 720; pol. Majów 825; m. Pleskierówką a g. Raztoki 1000; Konarki 880; g. Wielka Racza 1100; H. Mała Racza 1135; m. g. Upłaz i g. Wielka Racza 1065; Królowa 780; g. Bednarów Beskid 950; m. pol. Majcherowa i Pietrówka 1120; g. Kikula 1100. P: g. Juszczynka 880; g. Kotarnica 980; g. Palenica 685; dol. poniżej Uszczawnego 800; dol. W Kotarnicy 735; Knoski 670; H. Szczawina 1060; g. Prusów 1000; pot. Glinna 1165; g. Pilsko 1385, 1425; Kozi Grzbiet 1300; H. Skórzacka 1125; H. Bacmańska 1125; H. Bieguńska 1150; g. Rysianka 1320; przeł. Glinne 910; m. g. Trzy Kopce i g. Magurka 1180; Graberki 920; pol. Gruszkowa 1000; Śmierdzący Potok 1055; pot. Z Gawłowskiego 720; dol. Straceńca 695; g. Długi Groń 880. BG: przel. Brona 1420; Cyl 1485; Akademicka Perć 1457; Diablak 1650. J: Beskidek 1010; pot. Czerna 580; powyżej Drwalówki 690; pot. Głucha 680; Grzechynia 550; E ramię g. Jałowiec 1030, m. g. Jałowiec a g. Buciorys 775; przeł. Jałowiecka 1017; g. Kamienna 700; H. Kamińskiego 1118; g. Kiczora 850; przeł. Klekociny 890; Kolędówka 840; H. Kubalkowa 1000; g. Magurka 870; Podjałowiec 950; Opaczne 900; Siwcówka 600; g. Skupniówka 650; g. Sumerówka 565; pot. Surmiaków Potok 550; g. Urwisko 660; g. Westka 930; g. Witkowka 740; dol. Zasepnicy 440; Złabne 680.

Placynthium nigrum (Huds.) S. Gray - Wapniste skałki piaskowcowe, wapienie, betonowe obiekty (mosty. bunkry, studnie, mury); pg., rg. d.

10 stan. WR: pot. Nieledwianka 460; Rycerka 560; pot. Butorza 590; Pietraszyna 840. P: m. Sporyszem a g. Grojec 430; Sporysz 420; pot. Urwisko 700; Zająców Potok 800. J: g. Czerniańska 500; dol. Gołyńki 520 .

P. tremniacum (Massal.) Jatta - Wapienne skałki; miejsca pionowe i cieniste; pg.

1 stan. P: Sporysz 420.

Platismatia glauca (L.) W. Culb. \& C. Culb. [= Cetraria glauca (L.) Ach.] - Kora drzew iglastych oraz liściastych, niekiedy martwe drewno (dachy szałasów); rg. d., rg. g.

87 stan. WR: pot. Czadeczka 560; g. Trojaki 615; rez. Butorza 620; g. Kiczora ponad Mytem 800; g. Rachowiec 800; g. Jaworzyna 900; H. Muńczoł 1105; dol. Cicha 600; pot. Plaskurówka 710; Pętkówka 650; pol. Raztoki 900; pol. Skrzadnita 1105; g. Pleskierówka 1085; g. Będoszka Wielka 1100; las Solisko 650; pot. Racza 755; g. Wielka Racza 1180, 1210; g. Rycerzowa 1180; g. Rycerzowa Wielka 1195; pot. Urwisko 705; rez. Śrubita 780, 990; rez. Oszus 1000, 1110, 1150; g. Bednarów Beskid 1050; las Orzeł 985, 1030. P: g. Romanka 1355, 1360, 1365; H. Wieprzska 1110, 1175; dol. W Ciemnym 900; g. Jodłowcowa 1100; pol. Juraszka 1000; Żabnicka Rzeka 600; g. Rysianka 1300, 1320; g. Pilsko 1360; las poniżej H. Mędralowej 1290; las powyżej H. Mędralowej 1340; g. Palenica 1320; pot. Glinna 1200; g. Szczawinka 
1200, 1300, 1315; pol. Między Młaki 1225; las powyżej H. Miziowej 1360; g. Boraczy Wierch 1160; H. Bacmańska 1125; H. Bieguńska 1150; g. Lipowska 1260, 1280, 1310; las poniżej H. Lipowskiej 1100; dol. Bystra 875; dol. Z Wideł 950; g. Magurka k. Trzech Kopców 1033; Śmierdzący Potok 1090; Złotnice 925; g. Bucioryska 795; Bura Polana 665; Placówka 710; Stara Piła 780; Złatna 600; g. Okrągła 940; Jastrzębie 660; dol. Straceńca 870; gajówka Straceniec 775; m. pol. Plekońka i Krawcula 1000; g. Krawców Wierch 1060. BG: las powyżej H. Czarnej 1200, 1260; m. Markowymi Szczawinami a przeł. Brona 1255, 1310; las poniżej Akademickiej Perci 1235, 1340; Sokolica 1310. J: m. g. Kamienną a g. Surzynówką 700; poniżej g. Mędralowa 850; Pindelówka 1000; H. Kubalkowa 1000; H. Trzebuniaków 1020; H. Kamińskiego 1050; g. Mędralowa 1150.

\section{Polyblastia cruenta (Koerb.) P. James \& Swinscow $[=P$. henscheliana $($ Koerb.)} Lönnr.] - Bezwapienne głazy piaskowcowe zanurzone w wodzie potoków górskich; rg. g.

1 stan. P: pot. Glinna 1340.

P. cupularis Massal. [ $=$ P. intercedens (Nyl.) Lvnnr.] - Według SteINA (1872) występuje na Babiej Górze; obecnie nie potwierdzony.

P. kutakii Serv. - Kamienie piaskowcowe w pobliżu źródła, ale nie zanurzone w wodzie; rg. d.

1 stan. J: H. Kamińskiego 1090.

P. pallescens Anzi - Według ZsChaCKEGO (1934) występuje na Babiej Górze; obecnie nie potwierdzony.

P. sendtneri Krempelh. - Według STEINA (1872) występuje na Babiej Górze; obecnie nie potwierdzony.

Polysporina lapponica (Ach. ex Schaer.) Degel. [= Acarospora silesiaca $\mathrm{H}$. Magn.] - Bezwapienne piaskowce (stosy kamieni, luźne murki, głazy po polanach); miejsca suche i widne; pg., rg. d.

38 stan. WR: g. Kiczorka 685; g. Ochodzita 760; Graniczne 790; Stawiska 770; Przysłop Połucki 870; Szczytkówka 875; g. Jaworzyna 900; Na Praszywce 950; g. Praszywka Duża 980, 1030. P: H. Durajka 835; g. Kiczora 840; pol. Boruć 840, 890; g. Przypór 855; H. Boracza 865; g. Prusów 1000; Sucha Góra 1020, 1040. BG: Kościółki 1515; ruiny schroniska pod Diablakiem 1600. J: dol. Kalinki 540; g. Skupniówka 600; g. Witkówka 650; g. Surmiaków Groń 730; dol. Bystrej 750; Jałowiec 750; g. Surzynówka 770; Janiki 770; Kolędówka 800; poniżej g. Przyborówka 850; g. Magurka 870; g. Kiczora 900; Podjałowiec 965.

P. simplex (Dav.) Vězda [= Sarcogyne simplex (Dav.) Nyl.] - Bezwapienne piaskowce (skały i kamienie nierzadko w kopcach); miejsca suche i widne; rg. d., rg. g., kos.

10 stan. WR: H. Muńczoł 1120. P: pol. Boruć 840; g. Baścikówka 850; Sucha Góra 1020; H. Wieprzska 1060; g. Pilsko 1385, 1420. BG: ruiny schroniska pod Diablakiem 1600. J: g. Mędralowa 1170.

Porima ef. austriaca (Koerb.) Arnold [= Arthopyrenia austriaca (Koerb.) J. Nowak \& Tobol.] - Bezwapienne głazy piaskowcowe leżące $w$ wilgotnych miejscach, np. nad brzegami potoków górskich w zbiorowiskach leśnych często zwilżanych wodą; $r$ g. d.

5 stan. WR: pot. Leżaje 750; g. Będoszka Mała 900. P: blisko H. Boraczej 725; rez. Rysianka 900; blisko pol. Bartek 1130.

P. mamillosa (Th. Fr.) Vain. - Jałowa gleba wśród skał piaskowcowych; kos. 2 stan. BG: Diablak 1710, 1725.

Porpidia albocaerulescens (Wulf.) Hertel \& Knoph [ = Lecidea albocaerulescens (Wulf.) Ach.] - Cieniste skałki piaskowcowe, głazy w lesie; rg. g. 1 stan. P: blisko pol. Bartek 1130 . 
P. cinereoatra (Ach.) Hertel \& Knoph [= Lecidea cinereoatra Ach.] - Bezwapienne piaskowce (głównie drobne kamienie na nieużytkach i przydrożach); miejsca suche i widne albo lekko wilgotne; pg., rg. d., rg. g., kos.

9 stan. WR: H. Przysłop 950. P: g. Groń 600; pot. Sopotnia Wielka 735; H. Redykalna 1140; H. Cudzichowa 1250; g. Pilsko 1385. 1400. J: g. Magurka 870; g. Kwakowa 670.

\section{P. crustulata (Ach.) Hertel \& Knoph [Lecidea crustulata (Ach.) Spreng.] - Bez-} wapienne piaskowce (stosy kamieni, luźne murki, kamienie nad potokami, zwłaszcza kamieńce nad rzekami); pg., rg. d., rg. g., kos.

117 stan. WR: g. Zabawa 740; pot. Czadeczka 530; g. Kiczorka 685, 725; m. Krutakami i Tarlicznem 635; g. Popręcina 775; Staronie 760; pol. Butorza 740; m. Rycerką i Rajczą 500; g. Groniczek 830; pot. Głęboki 700; g. Skalanka 785; Ujsoły 520; H. Hutyrów 650; Stawiska 770; g. Oźna 790; Płaskonków 650; pol. Jaworskie 610; Zimna Woda 650; dol. Danielki 700; g. Praszywka Duża 1030; H. Muńczoł 1120; g. Magura 1000; Podścigłów 700, 720; pot. Stasiowa 700; pol. Bułkowa 760; pol. Raztoki 700, 730; pot. Racza 770, 835; H. Przysłop 940; g. Rycerzowa 1205; g. Upłaz 1020; g. Kikula 1100. P: g. Grojec 610; m. Sporyszem a g. Grojec 415; Sporysz 420; Przyłęków 550; g. Groń nad Przyłękowem 700; Sopotnia Wielka 735; g. Kotarnica 980, 1000; g. Kiczora 800; Na Skale 860; pot. Bystra 640; g. Juszczynka 880; H. Miziowa na Romance 1075; dol. Pod Uszczawnym 800; g. Malarka 1050; dol. W Kotarnicy 735; Duraje 610; H. Wieprzska 1060; pot. Studziański 660; pot. Suchy 630; pol. Budówka 665; Kolonia 750; dol. Solarzówki 485; pol. Kosarzyska 620; g. Rysianka 1310; g. Pilsko 1375, 1400; las powyżej H. Mędralowej 1320; pol. Szczyrbowe Młaki 890; H. Lipowska 1140, 1250; g. Boraczy Wierch 1240; pol. Gruszkowa 1000; m. Śmierdzącym i Zająców Potokiem 1025; Szeroki Kamieniec 780, 900; pot. Połom 780; Potok Jakubowski 630; pol. Pogwarówka 925; g. Bucioryska 795; Sułki 665; pol. Plekońka 960; pol. Głębokie 580; g. Długi Groń 820. BG: Cyl 1485; Kościółki 1510, 1580; Główniak 1570; Akademicka Perć 1480; pot. Kiczorka 1130. J: g. Babiarzówka 860; Baranówka 700; Beskidek 1010; Boguniówka 525; g. Gawronowa 580; dol. Grzechynki 550; g. Jałowiec 1100; g. Janoszka 670; H. Kamińskiego 1118; g. Kiczora 900; Kijakowa 810; g. Kiklówka 745; przeł. Klekociny 890, 930; Kolędówka 840; dol. Bystrej 590; g. Lachów Groń nad Bystrą 1045; pol. Magurka 880; Podjałowiec 950; Matusy 510; g. Mędralowa 1170; Opaczne 960; g. Ostra Górka 610; g. Sumerówka 565; pot. Surmiaków Potok 580; g. Kwakowa 670; g. Szelust 900; dol. Zasepnicy 470.

P. macrocarpa (DC. in Lam. \& DC.) Hertel \& Schwab [= Lecidea macrocarpa DC. in Lam. \& DC.] - Bezwapienne piaskowce (stosy kamieni, luźne murki, głazy nad potokami, rzadko naturalne skałki); pg., rg. d., rg. g., kos.

187 stan. WR: g. Zabawa 600, 655, 740, 760, 800; g. Popręcina 775; g. Kiczorka 750, 795; Do Staroni 770; g. Kiczora 700; Tomusie 575; pol. Butorza 740; Głębokie 660; g. Groniczek 830; H. Rachowiec 910; Rycerka 500, 530; g. Klimasy 710; g. Beskid Wrzeszcz 860; g. Solański Groń 705; g. Łysica 680; pot. Rycerka 580, 600; dol. Danielki 700; g. Hutyrów 670; Stawiska 770; Szczytkówka 870, 875; Rycerka Dolna 550; g. Jaworzyna 930, 985, 1020; Obłaz 830; g. Praszywka Duża 980, 1030, 1040; pol. Wyrobniówka 925; g. Muńczoł 1120, 1165; m. Podścigłów i Magura 770; przys. Magura 850; m. górami Jaworzyna i Magura 945; Przysłop Połucki 870; g. Kotarz 1080; g. Wiertalówka 1040; pol. Joneczkowe Rycerki 715; pol. Raztoki 750; H. Przysłop 940; g. Będoszka Wielka 1100; pol. Kołyska 1010; g. Petrykowa 1050; H. Mała Racza 1070, 1120; pot. Głowa 925; H. Śrubita 1000. P: g. Jastrzębica 750; pot. Loraniec 480; Duraje 610, 730; g. Przypór 855; dol. Sopotni Wielkiej 850; H. Durajka 835; g. Juszczynka 880; g. Kotarnica 880, 1010, 1150; H. Majerkowa 1075; dol. W Ciemnym 1170; g. Łazy 965; g. Palenica 665; pol. Boruć 895; g. Prusów 965, 975; H. Wieprzska 1060, 1100; H. Miziowa na Romance 1120; g. Skałka 1130, 1195; pol. Buczynka 880; Milówki 920; g. Romanka 1260; Kosarzyska 620; H. Szczawina 1115; m. Sznurkami i Dadokami 865; Sikorczany Potok 735; H. Rysianka 1240; g. Pilsko 1375, 1400, 1450, 1500, 1535; las powyżej H. Mędralowej 1320; Sucha Góra 750, 920, 1040; H. Szczawinka 1315; m. halami Miziową i Jodłowcową 1250; pot. Boracza 1025; H. Skórzacka 1125; H. Bieguńska 1160; H. Lipowska 1200, 1250; g. Trzy Kopce 1200, 1215; Zająców Potok 1000; przys. Graberki 900; g. Boraczy Wierch 1100; H. Motykowa 1050; pol. Gruszkowa 1000; Dziaski 735; Zapolanka 900; Szeroki Kamieniec 900; pot. Połom 780; Na Piętrze 835; g. Bucioryska 795; pot. Kościelec 695; dol. Z Gawłowskiego 645; g. Okrągła 850, 930; pot. Głęboki 580, 630; g. Długi Groń 880; pol. Pogwarówka 925; pol. Plekońka 960; pol. Krawcula 1035; g. Kubiesówka 850; 
Polany Pod Soblówką 900. BG: H. Czarna 1080; Kościółki 1480, 1510; m. Kościółkami i Diablakiem 1625; przeł. Brona 1450; Akademicka Perć 1300, 1555, 1590; Potok Suchy 1365; Diablak 1660, 1725; H. Kralowa 1080; las powyżej H. Kralowej 1395. J: dol. Bystrej 680; g. Biały Wierch 1040; Topory 700; Chudziakówka 500; pot. Czerna 500; Figury 810; g. Gawronowa 580; pot. Gołyńka 520; pot. Grzechynka 450; pot. Wilkówki 475; Jałowiec 750; g. Janoszka 720; H. Janoszkowa 1020; m. g. Jaworzyna a g. Szelust 900; pot. Kalinka 540; g. Kamienna 700; H. Kamińskiego 1100; Kijakowa 810; g. Kiklówka 745; dol. Bystrej 590; g. Lachów Groń nad Bystrą 1045; g. Lachów Groń nad Skawicą 600; Łabędzie 650; g. Magurka 870; pol. Magurka 880; Podjałowiec 995; g. Mędralowa 1170; Opaczne 960; g. Ostra Górka 610; pol. Skalaniec 850; g. Skupniówka 600; g. Sumerówka 565; g. Surmiaków Groń 730; pot. Surmiaków Potok 580; g. Surzynówka 800; g. Kwakowa 670; H. Trzebuniaków 1050; g. Wełczon 840; dol. Zasepnicy 440.

\section{P. melinodes (Koerb.) Gowan \& Ahti - Bezwapienne piaskowce (gołoborza} i piargi, głazy nad potokami wysokogórskimi); kos.

5 stan. P: źródliskowa część pot. Glinna 1335. BG: Kościółki 1510; Diablak 1660, 1675, 1725.

P. speirea (Ach.) Krempelh. $[=$ Lecidea speirea (Ach.) Ach. $]$ - Bezwapienne piaskowce (pionowe skały, głazy nad potokami górskimi); miejsca cieniste lub widne; rg. d. rg. g, kos.

21 stan. P: Żabnicka Rzeka 590; Na Piętrze 800; g. Boraczy Wierch 1100; H. Miziowa na Romance 1120; g. Skałka 1190; g. Romanka 1200, 1225, 1260; g. Szczawinka 1315. BG: Akademicka Perć 1480, 1525; Kościółki 1400, 1510, 1580; Diablak 1660, 1710. J: dol. Bystrej 600, 700; pot. Grzechynka 450; dol. Wilkówki 475; Matusy 520; pot. Surmiaków Potok 550.

P. tuberculosa (Sm. in Sm. \& Sow.) Hertel et Knoph [ = Lecidea tumida Massal., L. sorediza Nyl.] - Bezwapienne piaskowce, w miejscach cienistych niekiedy $\mathrm{z}$ apotecjami, w miejscach widnych i suchych przeważnie płonne; rg. d, rg. g., kos. 89 stan. WR: g. Zabawa 800; Burdówka 690; Młaki 700; Do Staroni 770; g. Kiczora 680, 700; g. Rachowiec 900; g. Klimasy 710; g. Hutyrów 670; g. Skalanka 800; Klimas 780; Szczotka 870; g. Oźna 920; przys. Stawiska 770; pot. Rycerka 600; przys. Szczytkówka 875; g. Jaworzyna 900, 985, 1020; g. Pras7ywka Duża 980, 1030; pol. Gardasówka 830; pol. Wyrobniówka 925; Magura 850; pot. Stasiowa 700 (z apotecjami); Przysłop Połucki 870; Skomisko 680; g. Wiertalówka 1040; pol. Joneczkowe Rycerki 715; pol. Raztoki 750; H. Przysłop 940; pol. Majów 825; g. Będoszka Wielka 1100; pol. Kołyska 1010; g. Rycerzowa 1205; pol. Majcherowa 1075; H. Mała Racza 1070; g. Wielka Racza 1235; pol. Głowa 925; H. Śrubita 1015. P: Przyłęków 550; Duraje 630; m. g. Kiczora i g. Magura 840; pot. Bystra 510 (z apotecjami); g. Magura 840, 870; g. Kotarnica 1010, 1160; H. Majerkowa 1075; dol. W Ciemnym 1170 (z apotecjami); pol. Boruć 795; pol. Na Boruć 895; g. Prusów 965; pol. Budówka 665; pol. Buczynka 880; g. Romanka 1260 (z apotecjami); pol. Alacowa 925; Kosarzyska 620 (z apotecjami); g. Skałka 1190; pol. Bartek 1140 (z apotecjami); g. Rysianka 1320 (z apotecjami); g. Pilsko 1375, 1400, 1420, 1450; H. Cudzichowa 1260; pol. Szczyrbowe Młaki 885; dol. Boracza 1025 (z apotecjami); H. Skórzacka 1125; H. Lipowska 1250; g. Trzy Kopce 1215; pol. Sucha Góra 920; g. Boraczy Wierch 1100; g. Szczawinka 1315 (z apotecjami); g. Okrągła 930; pot. Głęboki 630 (z apotecjami); g. Długi Groń 880; pol. Plekońka 960; g. Kubiesówka 850; Polany Pod Soblówką 900. BG: Akademicka Perć 1480 (z apotecjami); m. Kościółkami a przeł. Brona 1625; Kościółki 1600. J: g. Biały Wierch 1040; m. g. Jaworzyna a g. Szelust 900; g. Kamienna 710; Kubiasiaki 690; poniżej g. Przyborówka 860; H. Trzebuniaków 1040.

Protoblastenia rupestris (Scop.) Stnr. - Wapienie, wapniste piaskowce, np. świeże osuwiska, głazy nad potokami i rzekami, również obiekty murowane i betonowe (podmurówki, mosty, wiadukty); rg. d.

16 stan. WR: pot. Sucha Nieledwianka 520; Rycerka 530; pot. Butorza 590; Zwardoń 650; pot. Urwisko 700. P: Sporysz 390, 420; Kopce k. g. Grojec 470; pot. Suseński 480; g. Abrahamów 810; pot. Boracza 1025. J: dol. Grzechynki 450; pot. Dejówka 520; dol. Kalinki 540; dol. Głucha 600; Roztoki 600.

Protoparmelia badia (Hoffm.) Hafellner [= Lecanora badia (Hoffm.) Ach.] - Bezwapienne piaskowce (skałki, piargi i gołoborza, stosy kamieni, luźne murki, 
głazy nad potokami oraz po halach i polanach); miejsca suche i widne; rg. d., rg. g., kos.

130 stan. WR: g. Kiczorka 795; g. Ochodzita 820; g. Zabawa 760, 800; Młaki 700; Do Staroni 770; g. Kiczora 700; Tomusie 600; Głębokie 660; g. Klimasy 710; g. Oźna 870, 920, 930; g. Hutyrów 670; Rycerka 500; g. Kokocz 730; g. Jaworzyna 900, 995, 1020; g. Praszywka Duża 980, 1030; pol. Wyrobniówka 925; g. Muńczoł 1120, 1150, 1165; Magura 850; Przysłop Połucki 870; pol. Joneczkowe Rycerki 715; g. Będoszka Wielka 1100; pol. Kołyska 1010; g. Rycerzowa Wielka 1205; pol. Majcherowa 1075; g. Rycerzowa $1170 \mathrm{H}$. Śrubita 1000 g. Bugaj 1050. P: Duraje 610, 730; g. Przypór 820, 855, 880; g. Jastrzębica 750; m. g. Kiczora i g. Magura 840; g. Magura 850; g. Magurka 870; g. Łazy 965; g. Abrahamów 780, 830; H. Miziowa na Romance 1100; H. Majerkowa 1075; pol. Boruć 840; pol. Na Boruć 895; g. Prusów 965, 1000, 1005; g. Malarka 1050; H. Wieprzska 1060, 1100; Kolonia 750; pol. Buczynka 880; g. Skałka 1195; m. Sznurkami i Dadokami 865; H. Jodłowcowa 1200; g. Rysianka 1300; H. Rysianka 1240; g. Pilsko 1385, 1400, 1420, 1445, 1450, 1535; Sucha Góra 750; g. Sucha Góra 960, 1040; g. Solisko 1180; H. Bieguńska 1160; Graberki 850, 900; H. Redykalna 1060; H. Motykowa 1050; H. Lipowska 1130; g. Trzy Kopce 1215; g. Okrągła 930; g. Długi Groń 880; pol. Krawcula 1035; g. Kubiesówka 800; Polany Pod Soblówką 900. BG: Cyl 1460, 1485, 1515; Kępa 1520; Główniak 1570; Akademicka Perć 1590, 1610, 1670; Kościółki 1500, 1510, 1580, 1600; Diablak 1650, 1660, 1665, 1680, 1700, 1710, 1725; S stok pod Diablakiem 1600, 1610, 1660; Suchy Potok 1365. J: g. Czerniańska 500; g. Skupniówka 600; g. Surzyny 670; Kiklówka 700; Figury 700; g. Kamienna 720, 740; g. Surzynówka 800; Kijakowa 810; poniżej g. Przyborówka 850; g. Magurka 870; g. Wełczon 875; pol. Skalaniec 900; przys. Podjałowiec 995; g. Biały Wierch 1040; g. Lachów Groń nad Bystrą 1045; H. Kamińskiego 1118.

Protothelenella corrosa (Koerb.) Mayrh. \& Poelt [ = Microglaena corrosa (Koerb.) Arnold] - Bezwapienne piaskowce (skałki i głazy, nierzadko gruzowiska i większe skupienia kamieni); rg. d., rg. g., kos.

20 stan. WR: g. Jaworzyna 985; g. Muńczoł 1165; g. Rycerzowa Wielka 1205. P: Śmierdzący Potok 810; Sucha Góra 920; g. Romanka 1075, 1120, 1130; H. Rysianka 1200; g. Pilsko 1230, 1370, 1400, 1450; g. Szczawinka 1320. BG: Kościółki 1500; Akademicka Perć 1480; m. Kościółkami i Diablakiem 1625; Suchy Potok 1365.

P. sphincrinoidella (Nyl.) Mayrh. \& Poelt [ = Microglaena sphinctrinoidella (Nyl.) - Arnold] Obumarłe mchy lub naga gliniasta gleba; kos.

1 stan. BG: Kościółki 1580.

Pseudephebe pubescens (L.) Choisy [= Parmelia pubescens (L.). Vain.] - Bezwapienne piaskowce (głazy i piargi); kos.

8 stan. BG: Diablak 1660, 1675, 1680, 1700, 1710, 1725; S stoki Diablaka 1580, 1650.

Pseudevernia furfuracea (L.) Zopf [= Parmelia furfuracea (L.) Ach.] - Pnie i gałęzie drzew iglastych (świerki, modrzewie, jodły, kosodrzewina) i liściastych (samotne buki. jarzębiny) oraz martwe drewno (dachy szałasów i szop, drewniane studnie, parkany), rzadko podłoże skalne; rg. d., rg. g., kos.

106 stan. WR: Zapasieki 660; pot. Krążelka 510; rez. Butorza 620; m. górami Kiczora i Popręcina 685; Misiorka 700; Mandlówka 625; Pławuchowa 520; g. Jaworzyna 885, 900; H. Muńczoł 1100; dol. Plaskurówka 700, 735; g. Praszywka Mała 840; Pętkówka 650; Kolonia 670; pol. Cerla 1025; przys. Śliwkówka 730; pol. Raztoki 900; g. Wiertalówka 895; g. Będoszka Wielka 1100; Raztoki 700; las Na Kołysce 1000; pot. Racza 755; g. Mała Racza 815; Przegibek 1020; g. Wielka Racza 1210; pol. Głowa 815. P: g. Kępa 490; g. Grojec 610; Figury 575; g. Kotarnica 935, 1000; dol. W Kotarnicy 880; pol. Latynka 1000; g. Romanka 1360; g. Prusów 975, 1000; H. Wieprzska 1060, 1100; dol. W Ciemnym 900; pol. Budówka 665; pol. Buczynka 880; pol. Koziorka 800; g. Pilsko 1360, 1460, 1480, 1490, 1500; g. Palenica 1320; pot. Glinna 1200; pol. Między Młaki 1225; H. Cukiernicza Wyżnia 860; g. Rysianka 1300; g. Boraczy Wierch 1160, 1240; H. Lipowska 1100, 1250; g. Magurka k. Trzech Kopców 1080, 1145; g. Szczawinka 1310; g. Lipowska 1280, 1320; H. Rysianka 1150; las poniżej H. Mędralowej 1290; H. Redykalna 1060; pot. Bystra 875; dol. Z Wideł 950; m. pot. Śmierdzący Potok i Zająców Potok 1090; 
Zająców Potok 820; g. Bucioryska 795; Sułki 665; pot. Z Gawłowskiego 675; g. Okrągła 940, 1000; Polany Pod Soblówką 900; pol. Plekońka 960; m. pol. Plekońka i Krawcula 1000; pol. Krawcula 1035; g. Krawców Wierch 1065; gajówka Straceniec 775. BG: przeł. Brona 1410; Kościółki 1450, 1580; Sokolica 1380; Główniak 1570; Diablak 1660; pot. Kiczorka 1360, 1395; H. Kralowa 1255, 1320. J: pot. Surmiaków Potok 580, 600; poniżej g. Magurka 700; Barankowa 800; m. g. Jałowiec a g. Lachów Groń 800; Kolędówka 810; poniżej g. Mędralowa 850; g. Magurka 870; przeł. Klekociny 930; g. Czerniawa Sucha 1000; H. Kubalkowa 1000; H. Trzebuniaków 1030; g. Jałowiec 1100, 1110.

Pseudosagedia aenea (Wallr.) Hafellner \& Kalb [ = Porina carpinea (Pers. ex Ach.) A. Zahlbr.] - Pnie drzew liściastych o gładkiej korze, zwykle w naturalnych lasach; miejsca cieniste i wilgotne nad potokami, mroczne doliny; rg. d.

4 stan. WR: g. Biernatka 700; g. Bednarów Beskid 950; rez. Oszus 1000. P: g. Romanka 1075.

P. chlorotica (Ach.) Hafellner \& Kalb [ = Porina chlorotica (Ach.) Müll. Arg. $]$

- Bezwapienne piaskowce (skałki, głazy i kamienie) nad potokami górskimi; miejsca wilgotne i cieniste; pg., rg. d.

2 stan. WR: pot. Sucha Nieledwianka 520. P: g. Romanka 1075.

P. guentheri (Flot.) Hafellner \& Kalb [= Porina guentheri (Flot.) A. Zahlbr. $]$ - Bezwapienne skały piaskowcowe (pionowe ściany); miejsca suche, ale cieniste; rg. d.

1 stan. P: Na Piętrze 800.

Psilolechia clavulifera (Nyl.) Coppins [ = Lecidea clavulifera Nyl.] - Bezwapienne piaskowce; miejsca pionowe lub podwieszone i zacienione; rg. $\mathrm{g}$.

1 stan. P: P g. Romanka 1200.

P. lucida (Ach.) Choisy [= Lecidea lucida (Ach.) Ach.] - Bezwapienne piaskowce (skałki i kamienie leżące stosami lub ułożone w luźnych murkach); miejsca zacienione albo widnych; najczęściej w stanie płonnym; pg., rg. d.

25 stan. WR: Tomusie 575, 655; Młaki 700; Stawiska 770; g. Praszywka Duża 1030 (z apotecjami). P: Skałka 600 (z apotecjami); Dziaski 735; g. Okrągła 850; przeł. Przysłopy 860; Polany Pod Soblówką 900; Sucha Góra 930, 960 (z apotecjami); g. Prusów 975. J: Chudziakówka 500; pot. Czerna 430; g. Gawronowa 580; dol. Wilkówki 475; przys. Janiczki 500 (z apotecjami); g. Kamienna 700 (z apotecjami); Kowaliczki 600; g. Magurka 870 (z apotecjami); g. Skupniówka 600 (z apotecjami); g. Surzynówka 800 (z apotecjami); g. Kwakowa 670 (z apotecjami); g. Witkówka 650.

Ptychographa flexella (Ach.) Coppins [= Lithographa flexella (Ach.) A. Zahlbr.] - Butwiejące pniaki iglaste miejsca suche i widne; rg. d.

7 stan. WR: Płaskonków 600, 650; Misiorka 700. P: pot. Sopotnia Mała 700; pot. Kajdasówka 740; k. Kotrysiej Polany 780; las poniżej H. Bieguńskiej 1150.

Punctelia subrudecta (Nyl.) Krog [= Parmelia dubia (Wulf. in Jacqu.) Schaer.] - Kora drzew liściastych (wierzby, lipy, klony); pg.

5 stan. WR: Pławuchowa 520. P: Juszczyna 430; Cięcina 445. J: Semikówka 550; dol. Cicha 700.

Pycnothelia papillaria (Ehrh.) Dufour - Gliniasta gleba (obok ścieżek górskich, na nieużytkach, na wastewce gleby w zagłębieniach kamieni); miejsca suche i widne; pg., rg. d.

16 stan. WR: Rycerka 520, 585; pot. Głęboki 700; g. Klimasy 710; g. Hutyrów 670; g. Burów Groń 690. P: g. Groń 600; pot. Fułatów 430; pot. Loraniec 460; g. Grapa Żar 500; Bukowina 500; g. Kiczora nad Ujsołami 700; g. Abrahamów 780; g. Kiczora 800. J: m. Grzechynią a Skupniówką 450; m. Korbielowem a g. Przyborówka 650.

Pyrenula laevigata (Pers.) Arnold - Kora starych buków rosnących w naturalnych cienistych lasach; rg. d. 
4 stan. WR: las. Orzeł 980. P: Zająców Potok 940; rez. Rysianka 980, 1130, 1140. BG: las poniżej H. Czarnej 1040 .

Uwaga! Gatunek w dawniejszej literaturze dotyczącej porostów Karpat polskich był podawany błędnie jako P. nitidella (Glanc, Tobolewski 1960; NowaK 1965, 1967, 1968; KisZKa 1967a, b; Olech 1967, 1972, 1973).

P. nitida (Weig.) Ach. - Kora drzew liściastych w naturalnych lasach, głównie na starych bukach; rg. d.

48 stan. WR: g. Trojaki 615; g. Biernatka 700; g. Muńczoł 990; pol. Skrzadnita 1105; g. Przysłop Wielki 960; las Na Kołysce 1000; H. Rycerzowa 1100; g. Majcherowa 950; g. Rycerzowa 1120; rez. Śrubita 780, 810, 975; rez. Oszus 1010; g. Bednarów Beskid 950, 1000; dol. Śrubita 975; las Orzeł 920, 985, 1030. P: H. Miziowa na Romance 1075; H. Wieprzska 1110, 1150; pol. Buczynka 860; H. Łyśniowska 1090; pol. Kobyle Młaki 1000; rez. Rysianka 1100; dol. Boracza 1050; H. Bacmańska 1125; H. Bieguńska 1150; H. Lipowska 1100; H. Rysianka 1100; H. Motykowa 1050; Zająców Potok 940; dol. Stara Piła 900; g. Okrągła 925; g. Długi Groń 850; Polany Pod Soblówką 900. BG: pot. Marków 1130; las poniżej H. Czarnej 1040, 1060. J: Beskidek 1010; g. Czerniańska 580; las Czerniawa 980; pot. Głucha 600; H. Kamińskiego 1080; g. Mędralowa 1150; Podjałowiec 930; Podksięże 500; H. Trzebuniaków 1030.

P. nitidella (Flk. ex Schaer.) Müll. Arg. - Kora starych buków w naturalnych lasach; rg. d.

1 stan. J: H. Kamińskiego 1100.

Ramalina calicaris (L.) Fr. - Zapewne błędnie podana przez REHMANA (1879) z Babiej Góry; obecnie nie odszukana.

rg. d.

R. fallax Mot. - Kora drzew liściastych samotnie rosnących (buki, jesiony);

2 stan. WR: Szczotka 900. P: H. Pawlusia 1170.

R. farinacea (L.) Ach. - Kora drzew liściastych tworzących drzewostany w miejscach widniejszych lub samotnie rosnących, rzadziej drzewa iglaste (jodły); rg. d.

24 stan. WR: Piekło 620; pot. Plaskurówka 700; leśniczówka Pod Raczą 715; pot. Racza 755; Szczotka 900; g. Pleskierówka 700; pol. Skrzadnita 1105; g. Będoszka Wielka 1120. P: Żabnicka Rzeka 600; Złatna 600; Sułki 665; Placówka 710; pot. Połom 790; pol. Koziorka 800; H. Łyśniowska 1090; H. Rysianka 1100; g. Jodłowcowa 1100, 1200; H. Lipowska 1100; H. Bieguńska 1150. J: dol. Zasepnicy 460; H. Kamińskiego 1050.

R. fastigiata (Pers.) Ach. - Kora drzew liściatych pojedynczo rosnących; rg. d. 12 stan. WR: Piekło 629; g. Rachowiec 850; Pętkówka 650; Ciapków 700; pot. Racza 755. P: Bura Polana 665; Placówka 710; pol. Koziorka 800; H. Pawlusia 1170; H. Jodłowcowa 1200. J: dol. Zasepnicy 460. rg. d.

R. fraxinea (L.) Ach. - Kora drzew liściastych najczęściej samotnie rosnących;

5 stan. WR: Szczotka 900. P: Kotrysia Polana 730; g. Kotarnica 1000; g. Jodłowcowa 1110; H. Bacmańska 1125.

R. intermedia (Del. ex Nyl.) Nyl. - Wapniste piaskowce, powierzchnie pionowe lub nieco podwieszone; lekko zacienione; rg d.

1 stan. P: g. Boraczy Wierch 1100.

R. pollinaria (Westr.) Ach. - Kora starych buków; rg. d.

1 stan. WR: pol. Skrzadnita 1105.

Rhizocarpon alpicola (Hepp) Rabenh. - Bezwapienne piaskowce (piargi, głazy, skałki); kos.

17 stan. P: g. Pilsko 1440, 1500. BG: Kościółki 1510, 1580, 1600; Akademicka Perć 1590; Główniak 1570; m. Kościółkami a Diablakiem 1625; Diablak 1650, 1660, 1675, 1725; S stoki Diablaka 1580, 1600, 1610. 
Rh. badioatrum (Flk. ex Spreng.) Th. Fr. - Bezwapienne piaskowce (gołoborza, głazy i kamienie po halach, stosy kamieni, rzadziej luźne murki); rg. d., rg. g. 34 stan. WR: g. Łysica 550, 640; g. Hutyrów 700; Oźna 760; g. Skalanka 800; g. Beskid Wrzesz 860; Szczytkówka 865; Przysłop Połucki 870; pol. Wyrobniówka 900; g. Oźna 950; g. Jaworzyna 1020; g. Bugaj 1050; g. Magura 1060; g. Będoszka Wielka 1100; g. Rycerzowa 1150. P: g. Jastrzębica 750; Sucha Góra 750, 920; Kolonia 750; g. Abrahamów 780; pol. Boruć 795; m. g. Kiczora i g. Magura; pol. Na Boruć 895; Polany Pod Soblówką 900; g. Okrągła 900; Milówki 920; pol. Alacowa 925; g. Prusów 965; H. Skórzacka 1125; g. Solisko 1180; H. Lipowska 1140, 1200; H. Cudzichowa 1250.

Rh. distinctum Th. Fr. - Bezwapienne piaskowce (stosy kamieni, luźne murki, głazy i kamienie po halach i polanach, gołoborza oraz naturalne skałki); miejsca suche i widne; pg., rg. d., rg. g., kos.

56 stan. WR: g. Popręcina 775; g. Zabawa 760; g. Rachowiec 850, 910; g. Klimasy 710; pot. Z Głębokiego 550; Ujsoły 520; g. Łysica 550; Szczytkówka 875; m. g.Jaworzyna i g. Magurka 945; Magura 850; pol. Cerla 1025; pol. Kołyska 1010; g. Będoszka Wielka 1100; g. Jaworzyna k. Bugaja 1120. P: g. Grojec 610; Przyłęków 550; g. Jastrzębica 750; g. Przypór 855; H. Durajka 835; Sopotnia Wielka 735; H. Malarka 1000; g. Baścikówka 810; H. Wieprzska 1060; g. Skałka 1130; dol. W Ciemnym 1170; pol. Buczynka 880; pol. Alacowa 925; g. Baścikówka 880; Milówki k. H. Boracza 785; g. Rysianka 1240,1300; g. Pilsko 1420; H. Cudzichowa 1260; H. Jodłowcowa 1160; H. Skórzacka 1125; H. Bieguńska 1160; H. Lipowska 1250; g. Trzy Kopce 1215; Graberki 875; g. Boraczy Wierch 1160; g. Sucha Góra 1040; pol. Gruszkowa 1000; H. Redykalna 1080; H. Motykowa 1050; m. Zagroniem i Zapolanką 845; g. Okrągła 930; pot. Głębokie 580; pol. Plekońka 960; pol. Krawcula 1035. BG: H. Czarna 1080; pot. Kiczorka 1395. J: g. Magurka 870; poniżej g. Przyborówki 850; pol. Skalaniec 850; g. Wełczon 840.

Rh. geographicum (L.) DC. subsp. geographicum - Bezwapienne piaskowce (naturalne skałki i gołoborza, piargi, rzadziej stosy kamieni i luźne murki); miejsca suche i widne; rg. d., rg. g., kos.

45 stan. WR: H. Przysłop 950; g. Jaworzyna 985; pol. Kołyska 1010. P: Zapolanka 845; Polany Pod Soblówką 900; pol. Alacowa 925; g. Magura 970; g. Skałka 1130, 1195; pol. Krawcula 1035; g. Boraczy Wierch 1160; H. Bieguńska 1160; przeł. Pawlusia 1190; dol. W Ciemnym 1170; H. Cudzichowa 1260; g. Pilsko 1385, 1400, 1420, 1450, 1535. BG: Kępa 1520; Sokolica 1370; Akademicka Perć 1480, 1590, 1610, 1660; Potok Suchy 1365; Kościółki 1500, 1510, 1580; m. Kościółkami i Diäblakiem 1625; Cyl 1460; przeł. Brona 1450; Diablak 1660, 1680, 1770, 1710, 1725; S stoki Diablaka 1580, 1600, 1610.

Rh. geographicum (L.) DC. subsp. lindsayanum (Räs.) $[=R h$. lindsayanum Räs., $R h$. riparium $\mathrm{Rds}$ ] - Bezwapienne piaskowce (naturalne skałki, piargi i gołoborza, często stosy kamieni, luźne murki, głazy i kamienie po halach i polanach); miejsca widne; rg. d., rg. g., kos.

141 stan. WR: Pochodzita 760; g. Zabawa 600, 760, 800; Młaki 700; Do Staroni 770; g. Podgórka 795; g. Rachowiec 910; g. Klimasy 710; g. Skalanka 800; Graniczne 785; Szczotka 870; g. Oźna 880, 920, 930, 950; Stawiska 770; pol. Szczytkówka 870; m. g. Jaworzyna i g. Magura 945; g. Jaworzyna 865, 900, 1020; g. Praszywka Duża 970, 980, 1030; pol. Gardasówka 830; pol. Wyrobniówka 925; g. Muńczoł 1120; g. Magura 1060; Przysłop Połucki 870; pol. Cerla 1025; Młada Hora 985; H. Przysłop 940; g. Będoszka Wielka 1100; pol. Kołyska 1010; g. Rycerzowa 1170, 1205; H. Mała Racza 1135; g. Wielka Racza 1235; pol. Głowa 925; H. Śrubita 1000; g. Bugaj 1050. P: Duraje 730; g. Przypór 820, 855; g. Jastrzębica 750; m. g. Kiczora i g. Magura 840; H. Durajka 835; g. Magura 850, 870; g. Kotarnica 1010; g. Lazy 965; H. Majerkowa 1075; pol. Boruć 795, 840; pol. Na Boruć 895; g. Prusów 965, 1000, 1005; g. Abrahamów 830; g. Malarka 1000, 1050; g. Skałka 1130; pol. Buczynka 880; Milówki k. H. Boraczej 920; pol. Alacowa 925; g. Baścikówka 880; m. Sznurkami i Dadokami 865; przeł. Pawlusia 1170; H. Górowa 1100; g. Rysianka 1240, 1300; g. Pilsko 1375, 1385, 1420, 1445, 1500; H. Cebulowa 1270; H. Cudzichowa 1260; pol. Szczyrbowe Młaki 885; g. Solisko 1180; H. Skórzacka 1125; H. Bieguńska 1160, 1200; H. Lipowska 1130, 1150, 1200; g. Trzy Kopce 1200, 1215; pol. Sucha Góra 920; Graberki 900; g. Boraczy Wierch 1160; H. Redykalna 1060; pol. Gruszkowa 1000; H. Motykowa 1050; g. Sucha Góra 1000; przys. Dziaski 735; 
Zapolanka 850; g. Bucioryska 795; g. Okrągła 930; pot. Głęboki 580, 630; g. Długi Groń 880; pol. Plekońka 960; pol. Krawcula 1035; g. Kubiesówka 860. BG: Kępa 1520; Cyl 1485, 1515; Diablak 1725; H. Kralowa 1395. J: Baranówka 700; g. Biały Wierch 1040; N stok g. Czerniańska 450; Drwalówka 690; Figury 810; g. Gawronowa 580; dol. Wilkówki 475; Janiki 770; g. Kamienna 700; H. Kamińskiego 1050; g. Kiczora 900; g. Kiklówka 745; Kolędówka 800; Kubiasiaki 640; g. Lachów Groń nad Bystrą 1045; g. Lachów Groń nad Skawicą 600; g. Magórka 870; Podjałowiec 995; g. Mędralowa 1170; Opaczne 900; poniżej g. Przyborówka 850; pol. Skalaniec 900; g. Skupniówka 600,650; g. Surzynówka 800; g. Kwakowa 760; H. Trzebuniaków 1050; g. Wełczon 840; g. Witkówka 650.

Rh. hochstetteri (Koerb.) Vain. - Bezwapienne piaskowce (piargi, głazy); kos. 7 stan. BG: Kościółki 1400, 1600; Kępa 1520; Diablak 1660; S stok Diablaka 1600, 1610, 1650.

Rh. lavatum (Fr.) Hazsl. - Bezwapienne piaskowce; miejsca nieco wilgotne; rg. d., rg. g., kos.

14 stan. WR: pot. Sucha Nieledwianka 520; g. Petrykowa 1050; g. Kotarz 1080. P: H. Miziowa na Romance 1120, 1130; g. Krzyżowa 720; pot. Studziański 660; H. Wieprzska 1040; nad dol. Boraczej 1025; H. Słowikowa na Pilsku 1450; H. Rysianka 1150; g. Kubiesówka 800. J: Kubiasiaki 690; H. Trzebuniaków 1040.

Rh. lecanorinum Anders. - Bezwapienne piaskowce (gołoborza i gruzowiska); miejsca suche i nasłonecznione; $\mathrm{rg}$. d.

2 stan. P: g. Abrahamów 830; H. Boracza 920.

Rh. obscuratum (Ach.) Massal. - Bezwapienne piaskowce (stosy kamieni. luźne murki, głazy po halach i polanach, nad brzegami rzek i potoków, naturalne skały); miejsca suche i widne albo nieco cieniste i lekko wilgotne; pg., rg. d., rg. g., kos. 120 stan. WR: g. Zabawa 600; g. Kiczorka 685; g. Popręcina 775; g. Sołowy Wierch 840; Młaki 700; Myto 675; Do Staroni 770; Tomusie 575; pol. Butorza 740; g. Rachowiec 910, 950; g. Hutyrów 670, 700; g. Skalanka 800; g. Beskid Wrzeszcz 860; pot. Rycerka 580, 600; Szczytkówka 870, 875; g. Jaworzyna 985, 1020; g. Praszywka Duża 980; pol. Gardasówka 830; H. Muńczoł 1120; m. przysiółkami Podścigłów i Magura 770; pol. Bułkowa 760; Przysłop Połucki 870; Rycerki 655; Skomisko 680; pol. Joneczkowe Rycerki 715; H. Przysłop 940; pot. Dzięboki 770; pol. Kołyska 1010; g. Będoszka Wielka 1130; g. Rycerzowa 1150; H. Mała Racza 1135; g. Wielka Racza 1235; pol. Głowa 940; H. Śrubita 1000; g. Abramów 1080. P: g. Przypór 855; Na Skale 860; H. Durajka 835; g. Magury 970; g. Kotarnica 1000, 1015, 1160; dol. pod Uszczawnym 800; H. Majerkowa 1075; dol. W Ciemnym 1170; pot. Suchy 630; g. Prusów 965, 975; g. Baścikówka 810; H. Wieprzska 1060; Kolonia 750; Kosarzyska 620; g. Skałka 1195; H. Szczawina 1115; Milówki k. H. Boraczej 785; m. Sznurkami i Dadokami 865; Sikorczany Potok 735; H. Jodłowcowa 1200; g. Pilsko 1375, 1385, 1400, 1500; las powyżej H. Mędralowej 1320; H. Cebulowa 1270; pol. Szczyrbowe Młaki 890; H. Rysianka 1240; H. Bieguńska 1160; g. Jaworzyna k. Pilska 1090; g. Trzy Kopce 1200; g. Sucha Góra 920, 1020; m. H. Redykalną a Zapolanką 1050; g. Bucioryska 795; pot. Połom 780; g. Okrągła 930; Zająców Potok 800; pol. Pogwarówka 925; pol. Krawcula 1035; Polany Pod Soblówką 900. BG: H. Czarna 1080; Suchy Potok 1365; Akademicka Perć 1480, 1500; przeł. Brona 1450. J: Baranówka 700; g. Biały Wierch 1040; powyżej Drwalówki 690; Figury 810; g. Gawronowa 580; pot. Głucha 580; Jałowiec 750; Janiki 770; g. Janoszka 720; H. Janoszkowa 1020; pot. Kalinka 540; g. Kamienna 710; g. Kiczora 900; pot. Kolędówka 650; przys. Kolędówka 800; H. Kubalkowa 1100; g. Lachów Groń nad Bystrą 1045; g. Magurka 870; pol. Magurka 880; g. Mędralowa 1170; Opaczne 900, 960; g. Ostra Górka 600; Pindelówka 1050; poniżej g. Przyborówka 850; pol. Skalaniec 900; g. Skupniówka 600; g. Surmiaków Groń 730; g. Kwakowa 670; g. Witkówka 650.

Rh. petraeum (Wulf.) Massal. [ $=$ Rh. concentricum (Dav.) Beltr., Rh. excentricum (Ach.) Arnold] - Lekko wapniste lub bezwapienne piaskowce (skałki naturalne, głazy nad potokami, osuwiska skalne, mury oporowe potoków); miejsca nieco cieniste; pg., rg. d., rg. g., kos.

32 stan. WR: pot. Sucha Nieledwianka 520; Rycerka 490, 520; pot. Czadeczka 530; pot. Z Głębokiego 550; pot. Rycerka 580, 600; Skomisko 680; Podścigłów 700, 770; pot. Stasiowa 700; pot. Plaskurówka 700; pot. 
Urwisko 700; g. Klin 800; pot. Racza 835. P: Sporysz 420; Głębokie 580; Żabnicka Rzeka 590; Kosarzyska 620; pot. Studziański 660; Na Piętrze 800; Zająców Potok 800; g. Długi Groń 820; pot. Boracza 1025, 1050; pol. Krawcula 1035; pot. Glinna 1305; g. Pilsko 1400. J: pot. Grzechynka 450; dol. Wilkówki 475; Roztoki 610; pot. Surmiaków Potok 550.

Rh. polycarpum (Hepp) Th. Fr. - Bezwapienne piaskowce (stosy kamieni, luźne murki, rzadziej naturalne skałki, głazy nad potokami i gołoborza); miejsca widne i suche; rg. d., rg. g., kos.

78 stan. WR: Do Staroni 770; g. Podgórka 785; g. Rachowiec 850; g. Oźna 920; g. Kokocz 720; Oźna 780; Płaskonków 680; g. Hutyrów 740; m. g. Jaworzyna i g. Magura 945; H. Muńczoł 1120; g. Praszywka Duża 1030; g. Magura 1060; pol. Bułkowa 760; H. Przysłop 940; g. Będoszka Wielka 1100; H. Rycerzowa 1140; g. Wielka Racza 1100; H. Mała Racza 1120; pol. Głowa 925; H. Śrubita 1000; g. Abramów 1080; g. Jaworzyna koło Bugaja 1100. P: g. Przypór 855; g. Magura 870; g. Abrahamów 830; Tokarnia 780, 890; pot. Suchy 630; pol. Boruć 795, 840; H. Malarka 1000; pol. Buczynka 880; pol. Alacowa 925; g. Baścikówka 880; Milówki 920; m. Sznurkami i Dadokami 865; przeł. Pawlusia 1170; H. Łyśniowska 1190; g. Skałka 1195; H. Jodłowcowa 1160; H. Górowa 1100; leśniczówka Glinne 750; pol. Kobyle Młaki 1000; H. Cudzichowa 1250; g. Pilsko 1400; g. Sucha Góra 1000, 1400; H. Lipowska 1150, 1200; Zapolanka 850; g. Okrągła 940; Polany Pod Soblówką 900. BG: przeł. Brona 1450. J: g. Gawronowa 580; Drwalówka 690; g. Ostra Górka 610; dol. Grzechynki 450; dol. Wilkówki 475; Kubiasiaki 690; g. Skupniówka 600, 650; Janiki 770; g. Surzynówka 800; dol. Kalinki 540; g. Kiczora 900; g. Lachów Groń nad Skawica 600; Roztoki 680; Baranówka 700; Łabędzie 650; g. Biały Wierch 1040; g. Kiklówka 745; dol. Bystrej 590; g. Welczon 800; g. Magurka 880; dol. Głucha 600; g. Mędralowa 1170.

Rinodina archaea (Ach.) Arnold - Kora starych drzew iglastych, np. jodeł, na skraju lasu; rg. d.

1 stan. J: Opaczne 940.

R. bischoffii (Hepp) Massal. - Wapienie w miejscach suchych i widnych; pg. 1 stan. P: Sporysz 420.

R. exigua (Ach.) S. F. Gray - Kora drzew liściastych; rg. d.

2 stan. P: leśniczówka Straceniec 775; H. Jodłowcowa 1200.

R. gennari Bagl. [ $=R$. subexigua (Nyl.) Oliv., R. salina Degel.] - Bezwapienne piaskowce (stosy kamieni, murowane mosty); pg., rg. d.

2 stan. P: pot. Suseński 480; Tokarnia 890.

R. pyrina (Ach.) Arnold - Martwe drewno (belki, ogrodzenia, deski szop, poręcze mostów) albo kora drzew liściastych rosnących koło dróg; pg., rg. d.

6 stan. WR: Ujsoły 530; Słonkówka 625; pot. Urwisko 780; przys. Przegibek 1020. P: pot. Nickulina 520; Zlatna 640.

Sarcogyne privigna (Ach.) Massal. - Bezwapienne piaskowce, skałki nad brzegami potoków górskich; miejsca suche i widne; rg. d.

1 stan. WR: pot. Urwisko 700 .

S. regularis Koerb. [ $=S$. pruinosa auct.] - Wapniste piaskowce, wapienie, beton (wiadukty); miejsca widne i suche; pg., rg. d.

9 stan. WR: Rycerka 530; g. Łysica 550; przys. Płaskonków 650; pot. Urwisko 700. P: g. Kopce k. Grojca 470; Sporysz 420; pot. Suseński 480; pot. Studziański 660. BG: ruiny schroniska na S stoku Diablaka 1600.

Sarcosagium campestre (Fr.) Poetsch \& Schied. [ = Biatorella campestris (Fr.) Almqu.] - Murszejące drewno, przeważnie czołowe powierzchnie pniaków iglastych, poręby; pg., rg. d.

3 stan. WR: pot. Czadeczka 545; pot. Czerna 610; pot. Danielka 700.

Schaereria fuscocinerea (Nyl.) Clauz. \& Roux [= Lecidea tenebrosa Flot.] - Bezwapienne piaskowce (głazy, skały); miejsca suche i widne; kos.

3 stan. BG: Sokolica 1370; Diablak 1710, 1725. 
Schismatomma pericleum (Ach.) Branth \& Rostr. $[=S$. abietinum (Humb.) Massal.] - Kora starych drzew iglastych (świerki), wyjątkowo liściastych (buki); rg. d.

1 stan. P: pol. Między Młaki 1200.

Scoliciosporum chlorococcum (Graewe ex Stenh.) Vězda [ = Bacidia chlorococca (Graewe ex Stenh.) Lettau] - Kora drzew iglastych rzadziej liściastych; pg., rg. d. 55 stan. WR: g. Kiczora 800; Tarliczne 635; g. Zabawa 790; pot. Czadeczka 570; pot. Krążelka 510; Zagajka 625; g. Syberia 550; Orawcowa 775; g. Rachowiec 850; Kołyska 1000; pol. Bułkowa 785; Na Praszywce 950; g. Wiertalówka 895; pol. Głowa 815; pot. Danielka 725; g. Kotarz 1190; g. Beskid Wrzeszcz 860; g. Wielka Racza 1100; H. Przysłop 950; g. Oźna 900. P: g. Kępa 490; pol. Żor 700; leśniczówka Janikówka 415; g. Kotarnica 870; pol. Pogwarówka 925; g. Krawców Wierch 1065; pot. Loraniec 520; pol. Sucha 940; rez. Rysianka 1000; las Tajch 750; Kolonia. BG: przeł. Brona 1410. J: pot. Surmiaków Potok 580; g. Czerniawa Sucha 1000; g. Kiczora 890; pot. Głucha 600; pot. Cicha 635; Pytel 600; g. Magurka 870; g. Sumerówka 565; g. Grzechynia 500; g. Janoszka 700; g. Urwisko 610; m. Chrząszczami a Toporami 800; m. g. Jałowiec a g. Lachów Groń 850; Zimna Woda 675.

S. umbrinum (Ach.) Arnold [= Bacidia umbrina (Ach.) Bausch] - Bezwapienne lub słabo wapniste piaskowce (stosy kamieni, luźne murki, murowane mosty, rzadko naturalne skałki); pg., rg. d.

25 stan. WR: Tomusie 600; pot. Głęboki 700; Ochodzita 760; g. Podgórka 795; g. Łysica 550; g. Solański Wierch 705; pot. Danielka 725; g. Hutyrów 700; Graniczne 785; Przysłop Połucki 870. P: g. Grapa Żar 430; Sporysz 420; pot. Suseński 480; g. Abrahamów 700; pot. Romanka 700; Dziaski 735; m. g. Kiczora i g. Magura; pol. Buczynka 880; pol. Na Boruć 890; g. Kotarnica 1010; H. Jodłowcowa 1200. J: pot. Głucha 580; pot. Grzechynka 450, 575; g. Surzyny 670; dol. Wilkówki 460.

Sclerophora nivea (Hoffm.) Tibell [= Coniocybe nivea (Hoffm.) Arnold $]$ - Omszała kora starych buków u nasady pni, rosnących w starych naturalnych drzewostanach; rg. d.

1 stan. P: rez. Rysianka 1055.

Solorina crocea $($ L.) Ach. - Według STEINA (1872) rośnie na Babiej Górze; obecnie nie potwierdzony.

S. saccata (L.) Ach. - Według SUZY (1951) rośnie na Babiej Górze; obecnie nie potwierdzony.

Sphaerophorus fragilis (L.) Pers. - Według SuZY (1951) rośnie na Babiej Górze; obecnie nie potwierdzony.

S. globosus (Huds.) Vain. - Pnie oraz gałęzie starych świerków, często omszonych, w borach górnoreglowych, wyjątkowo na starych bukach, również na nagiej glebie wśród głazów piaskowcowych w piętrze kosodrzewiny; rg. d., rg. g., kos. 10 stan. P: rez. Rysianka 950, 1050; las poniżej H. Mędralowej 1250; źródła pot. Glinna 1260, 1300; g. Rysianka 1300; g. Lipowska 1300; g. Palenica 1320; g. Szczawinka 1300. BG: Akademicka Perć 1580, 1610.

Sphinctrina turbinata (Pers.) De Not. [ $=$ S. gelasinata $($ With.) A. Zahlbr. $]-\mathrm{Na}$ plesze porostu Pertusaria pertusa rosnących na korze starych buków; rg. d. 1 stan. J: H. Kamińskiego 1100.

Sporastatia polyspora $(\mathbf{N y l}$.$) Grumm. [=$ S. cinerea $($ Schaer.) Koerb. $]$ - Według SuZY (1951) rośnie na Babiej Górze; obecnie nie potwierdzony.

Stenocybe major Nyl. ex Koerb. - Kora starych jodeł w naturalnych lasach; rg. d.

1 stan. P: las k. przys. Jastrzębie 660 . 
S. pullatula (Ach. ex Sommerf.) Stein - Plecha skorupiastych porostów rodzaju Lecanora rosnących na korze szarych olch nad potokami; rg. d.

3 stan. WR: dol. Cicha 600. P: Złatna, u wylotu pot. Jakubowskiego 600. J: Boguniówka 525.

Stereocaulon condensatum Hoffm. - Gliniasta jałowa gleba, np. na skarpie nad drogą polną; pg.

1 stan. P: g. Grapa Żar 500.

S. nanodes Tuck. - Kamienie bezwapiennych piaskowców najczęściej leżących stosami obok pól lub tworzących gołoborza; miejsca widne i suche; pg., rg. d., kos. 16 stan. WR: g. Ochodzita 820; g. Łysica 550; g. Oźna 920; pol. Kołyska 1010; g. Bugaj 1050. P: g. Palenica 665; Kolonia 750; pol. Boruć 795; Sznurki 865; Sucha Góra 750, 920. BG: Diablak 1710. J: Drwalówka 690; dol. Kalinki 790; H. Trzebuniaków 1050.

S. pileatum Ach. - Bezwapienne kamienie piaskowcowe leżące stosami; miejsca widne i suche; rg. d.

1 stan. P: nad przys. Kolonia 750.

Stereocaulon vesuvianum Pers. - Bezwapienne piaskowce (piargi, głazy); kos. 6 stan. BG: Akademicka Perć 1610, 1660; Diablak 1650, 1725; S stok Diablaka 1580, 1610.

Sticta sylvatica (Huds.) Ach. - Według SteINA (1872) rośnie na Babiej Górze; obecnie nie potwierdzona.

Strigula stigmatella (Ach.) Harris [= Arthopyrenia faginea (Schaer.) Swinscow] - Stare, omszałe buki w naturalnych lasach, na mchach albo bezpośrednio na korze drzew; rg. d.

6 stan. WR: pot. Danielka 725; las Orzeł 980. P: rez. Rysianka 970; las poniżej H. Lipowskiej 1100; H. Górowa 1150. J: H. Kamińskiego 1100 .

Tephromela atra (Huds.) Hafellner in Kalb [= Lecanora atra (Huds.) Ach.] - Bezwapienne piaskowce (skały, gołoborza i piargi, stosy kamieni i luźne murki); miejsca suche i widne; pg., rg. d., rg. g., kos.

71 stan. WR: Rycerka 515; Myto 675; g. Kiczora 700; Młaki 700; g. Klimasy 710; g. Zabawa 760, 800; g. Łysica 550; g. Hutyrów 670, 700; g. Burów Groń 690; Przysłop Połucki 870; Szczytkówka 875; g. Oźna 880; g. Jaworzyna 900, 1020; g. Praszywka Duża 980; H. Śrubita 1000; pol. Kołyska 1010; g. Będoszka Wielka 1100; g. Muńczoł 1165. P: g. Grojec 610; Dziaski 735; Kolonia 750; pol. Boruć 840, 895; Zapolanka 850; Sznurki 865; Milówki 900; g. Łazy 965; g. Prusów 965, 1005; Sucha Góra 1000; g. Kotarnica 1010; pol. Krawcula 1035; g. Pilsko 1400, 1420, 1500. BG: Kępa 1520; Sokolica 1350; Kościółki 1510, 1580, 1600; Akademicka Perć 1525, 1555, 1590; Diablak 1660; S stok Diablaka 1610. J: dol. Grzechynki 450; m. Grzechynią a Skupniówką 450; dol. Kalinki 540; pot. Surmiaków Potok 550; g. Gawronowa 580; dol. Bystrej 600; g. Skupniówka 600; g. Witkówka 640; g. Surzyny 670; Figury 700; g. Surmiaków Groń 730; g. Kamienna 740; Janiki 770; g .Surzynówka 800; g. Wełczon 840; poniżej g. Przyborówka 850; g. Magurka 870; pol. Skalaniec 900; g. Biały Wierch 1040; g. Lachów Groń nad Bystrą 1045 .

Thamnolia subuliformis (Ehrh.) W. Culb. - Gleba między bezwapiennymi piaskowcami; kos.

10 stan. BG: Diablak 1660, 1665, 1690, 1700, 1710, 1715, 1725; m. Kościółkami a Diablakiem 1625 S stok Diablaka 1600, 1660.

T. vermicularis (Sw.) Schaer. - Według SUZY (1951) rośnie na Babiej Górze; obecnie nie potwierdzony.

Thelidium aeneovinosum (Anzi) Arnold [ = Involucrothele aeneovinosa (Anzi) Serv.] - Bezwapienne piaskowce zanurzone w czystej wodzie potoków górskich i źródeł; rg. d.

2 stan. P: pol. Bartek 1140. BG: Marków Potok 1135. 
T. aquaticum Serv. - Bezwapienne piaskowce (kamienie) zanurzone w czystej wodzie potoków górskich oraz źródeł; rg. d.

3 stan. WR: Szczotka 880. J: Adamy 690; H. Kamińskiego 1090.

T. eitneri A. Zahlbr. [ = Involucrothele eitneri (A. Zahlbr.) Serv.] - Bezwapienne piaskowce (kamienie) zanurzone w czystej wodzie źródeł; rg. d.

1 stan. J: Opaczne 925.

T. margaceum (Leight.) Zsch. [ = Involucrothele margacea (Leight.) Serv.] - Głazy piaskowcowe wystające ponad lustro wody potoków, zalewane wodą tylko w czasie większych przyborów; pg.

1 stan. J: dol. Grzechynki 540.

T. olivascens (A. Zahlbr.) J. Nowak \& Tobol. [ = Amphoroblastia olivascens (A. Zahlbr.) Serv.] - Głazy piaskowcowe okresowo zalewane wodą w łożyskach potoków lub w źródłach; pg., rg .d.

2 stan. J: Kowalówka 576; H. Kamińskiego 1090.

T. zahlbruckneri Serv. - Bezwapienne piaskowce zanurzone w czystej wodzie potoków górskich; pg., rg. d.

2 stan. P: pot. Fułatów 460 . J: poniżej Podjałowca 850.

Thelocarpon epibolum Nyl. - Czoła murszejących pniaków świerkowych i jodłowych; rg. d.

2 stan. P: g. Rysianka 1190. BG: Markowe Szczawiny 1200.

Th. intermediellum Nyl. - Butwiejące i rozkładające się pniaki w cienistych lasach; rg. d., rg. g.

14 stan. WR: pot. Butorzy 680; Królowa 760; pot. Racza 800; Na Praszywce 825; pot. Urwisko 860; g. Przysłop Wielki 985. P: Śmierdzący Potok 750; g. Okrągła 940; g. Romanka 1130; H. Bacmańska 1130; g. Boraczy Wierch 1160; g. Rysianka 1310. BG: m. Markowymi Szczawinami a przeł. Brona 1310. J: poniżej Pytla 550.

Th. laureri (Flot.) Nyl. - Murszejące drewno (poręcze mostów, parkany, belki, deski, studnie drewniane, ule) oraz bezwapienne piaskowce (kamienie) leżące pojedynczo po halach i polanach lub zsypywane w stosy na nieużytkach; pg,. rg. d. 38 stan. WR: pot. Nieledwianka 440; Milówka 440; Nieledwia 490; Rycerka 500; pot. Czadeczka 500; pot. Z Głębokiego 520; Rycerka Dolna 550; Groń k. Zwardonia 670; Wierch Czadeczka 680; g. Kiczora nad Mytem 800; g. Groniczek 830; Dziergasowie 560; Rycerki 645; pot. Stasiowa 650; Kolonia 670; g. Solański Groń 680; pot. Plaskurówka 680; Granica 780. P: Juszczyna 450; pot. Bystrzanka 500; pot. Rokitnia 500; pot. Nickulina 520, 600, 670; Sopotnia Wielka 570, 630; Żabnicka Rzeka 590; g. Palenica 630; przys. Ciapkówka 635; Złatna 640; pot. Wojtasi 690; g. Kiczora 700. BG: pot. Jałowiec 620. J: Grzechynia 400; dol. Kalinki 530; H. Kubalkowa 1090.

Thelomma ocellatum (Koerb.) Tibell [ = Cyphelium caliciforme (Flot.) A. Zahlbr.] - Stare drewno (słupki w płotach); miejsca widne i suche; tylko w stanie płonnym; rg. d.

1 stan. WR: Groń k. Zwardonia 670.

Thelotrema lepadinum (Ach.) Ach. - Kora starych drzew liściastych, niekiedy iglastych (jodły) rosnących w starych naturalnych drzewostanach; rg. d.

18 stan. WR: g. Trojaki 615; rez. Śrubita 780, 810, 850, 990; Las Ku Zimnej Wodzie 800; las Orzeł 930, 975; g. Bednarów Beskid 940, 950; rez. Oszus 1010, 1075. P: pot. Stara Piła 900; Zająców Potok 940; rez. Rysianka 1080, 1140. BG: las poniżej H. Czarnej 1040; las poniżej Sokolicy 1090. J: pot. Stracony Potok 600 .

Thrombium epigaeum (Pers.) Wallr. - Gliniasta gleba, zwykle na nieużytkach i przydrożach; miejsca suche i widne; rg. d. 
13 stan. WR: pot. Krążelka 670; pol. Raztoki 815. P: Dziaski 615; pot. Suchy 630; Duraje 710; H. Durajka 835; Kotrysia Polana 720; pol. Uszczawne 800; Zająców Potok 800; g. Romanka 1075. J: dol. Kalinki 700; Spikówka 650; pot. Surmiaków Potok 550.

Trapelia coarctata $(\mathrm{Sm}$.$) Choisy in Werner [= Lecidea coarctata (\mathrm{Sm}$.$) Nyl.]$ - Bezwapienne piaskowce (głazy i kamieńce nad potokami i rzekami, rzadziej kamienie po halach i polanach); miejsca widne i suche lub lekko wilgotne i cieniste; pg., rg. d.

62 stan. WR: g. Zabawa 655; Śliwkula 590; g. Popręcina 750; g. Hutyrów 650; g. Beskid Wrzeszcz 860; dol. Danielki 650; g. Jaworzyna 930; H. Muńczoł 1120; pot. Stasiowa 700; pol. Bułkowa 760; Przysłop Połucki 870; Las Ku Zimnej Wodzie 800; przys. Raztoki 700; leśniczówka Pod Raczą 715; pot. Dzięboki 740; pot. Racza 770, 835; g. Upłaz 1020. P: Przyłęków 550; Duraje 610; pot. Bystra 530; Sopotnia Wielka 650; g. Kotarnica 980, 1015; przeł. Przysłopy 810; pol. Boruć 795; m. g. Kotarnica i g. Romanka 1120; pot. Romanka 710; H. Wieprzska 1060, 1100; Za Kopcem 600; Kolonia 750; Kosarzyska 620; pot. Glinna 1150; H. Lipowska 1130; g. Sucha Góra 1040; pol. Gruszkowa 1000; H. Motykowa 1050; Śmierdzący Potok 950; Szeroki Kamieniec 780, 800; dol. Stara Piła 740; Na Piętrze 800; pot. Glębokie 580; Kotrysia Polana 735; pol. Plekońka 960; pol. Krawcula 1035. BG: pot. Kiczorka 1130. J: g. Biały Wierch 1040; dol. Bystrej 650; pot. Czerna 500; dol. Grzechynki 450; G. JaŁowiec 1100; H. Janoszkowa 1020; przel. Klekociny 920; pot. Kolędówka 650; pot. Magurka 830; g. Mędralowa 1170; poniżej Pytla 550; Roztoki 700; pot. Surmiaków Potok 550; g. Szelust 900; dol. Zasepnicy 440.

T. involuta (Tayl. in J. Mackay) Hertel - Bezwapienne piaskowce (skałki, głazy); rg. d.; gatunek przeoczony, zapewne pospolitszy.

1 stan. P: Sopotnia Wielka 650.

T. obtegens (Th. Fr.) Hertel - Bezwapienne piaskowce (stosy kamieni, luźne murki i inne siedliska niedawno odsłonięte dla rozwoju porostów); miejsca suche i widne; najczęściej w stanie płonnym, z soraliami; pg., rg. d., rg. g.

27 stan. WR: g Ochodzita 820; g. Klimasy 710 (z apotecjami); g. Kiczora 680, 700; g. Popręcina 775; g. Kiczorka 635; Staronie 765; g. Groniczek 830; g. Rachowiec 910; m. g. Jaworzyna i g. Magura 945; H. Śrubita 1015; H. Przysłop 940 (z apotecjami); Rycerka Dolna 550; g. Beskid Wrzeszcz 860; g. Oźna 920; g. Solański Groń 705. P: g. Grojec 610; g. Jastrzębica 750; g. Pilsko 1385; pol. Krawcula 1035; g. Bucioryska 795; Duraje 610; Na Skale 860; pot. Fułatów 575; g. Palenica 630, 710; g. Prusów 1000; pol. Kosarzyska 620. J: g. Szelust 900; Podjałowiec 965; Beskidek 1010; Figury 870.

T. placodioides Coppins \& P. James - Bezwapienne piaskowce (głazy nad potokami, po halach i polanach); gatunek przeoczony, znacznie pospolitszy; rg. d. 4 stan. WR: g. Hutyrów 680; Raztoki 640; Harmatowie 570. J: pot. Kolędówka 650.

Trapeliopsis flexuosa (Fr.) Coppins \& P. James [= Lecidea flexuosa (Fr.) Nyl.] - Murszejące drewno (pniaki, belki, ogrodzenia, dachy szałasów, drewniane studnie, poręcze mostów), niekiedy kora żywych drzew (jodły); najczęściej w stanie płonnym; pg., rg. d., rg. g.

50 stan. WR: g. Kiczorka 780; Wierch Czadeczka 680; Nieledwia 530; pol. Babczonka 620; g. Hutyrów 740; g. Jaworzyna 930; H. Muńczoł 1125; g. Praszywka Mała 840; pot. Stasiowa 650; Rycerki 620, 645; Młada Hora 940; pol. Majów 825; Kolonia 670; pol. Kołyska 1000. P: H. Miziowa na Romance 1075; H. Wieprzska 1060; dol. W Ciemnym 900; pol. Buczynka 880; pot. Bystrzanka 500; Krzoski 670; g. Romanka 1350; g. Boraczy Wierch 1160; H. Bacmańska 1125; przeł. Glinne 910; H. Motykowa 1050; m. pot. Śmierdzący i Zająców 1090; dol. Nickuliny 670; g. Bucioryska 795; Złatna 610; g. Okrągła 940; pot. Głęboki 595; Kotrysia Polana 780. J: Czerniawa Sucha 1005; pot. Grzechynka 590; g. Jałowiec 1030; m. g. Jałowiec a g. Buciorys 775; m. g. Jałowiec a g. Lachów Groń 950; przeł. Klekociny 890; Kolędówka 810; H. Kubalkowa 1000; Kubiasiaki 690; g. Magurka 800; pot. Magurka 800; poniżej g. Mędralowa 850; poniżej Podjałowca 800; dol. Zasepnicy 460; Zimna Woda 675; przys. Złabne 680. 
T. gelatinosa (Flk.) Coppins \& P. James [ = Lecidea gelatinosa Flk.] - Gliniasta gleba na skarpach dróg leśnych; miejsca nieco cieniste; często w stanie płonnym; rg. d., rg. g., kos.

25 stan. WR: dol. Danielki 790; zbocze nad Koszarkami 880 (z apotecjami); g. Będoszka Mała 900; pol. Cerla 980 (z apotecjami). P: Potok Jakubowski 605; dol. Pod Uszczawnym 670; Dziaski 615; pot. Z Gawłowskiego 710 (z apotecjami); dol. W Kotarnicy 735; pot. Połom 780; Na Piętrze 800; W Ciemnym 830 (z apotecjami); Na Skale 860; g. Kotarnica 935; g. Prusów 1000; pot. Glinna 1165; g. Szczawinka 1180; g. Solnisko 1190 (z apotecjami); powyżej H. Mędralowej 1270, 1320. BG: Kościółki 1580; Akademicka Perć 1555; Diablak 1660. J: Głuchaczki 900; g. Jałowiec 980.

T. granulosa (Hoffm.) Lumbsch [= Lecidea granulosa (Hoffm.) Ach.] - Naga gleba, humus, na nieużytkach, obok ścieżek górskich, wśród stosów kamieni; miejsca suche i widne; rg. d., rg. g., kos.

38 stan. WR: pot. Radecki 700; pot. Plaskurówka 735; Szczytkówka 735; pol. Wyrobniówka 925; g. Oźna 930; pol. Kołyska 1010; g. Magura 1050; g. Praszywka Duża 1030; H. Rycerzowa 1140. P: g. Prusów 1000; g. Lipowska 1350; g. Pilsko 1385, 1400, 1425, 1450; g. Długi Groń 880; g. Magurka 1145; Śmierdzący Potok 1010; pot. Glinna 920; Milówki 900; g. Jastrzębica 750; g. Trzy Kopce 1200. BG: Cyl 1450; Kościółki 1560; przeł. Brona 1420; m. Kościółkami a przeł. Brona 1450, 1490; Kępa 1530; S stok Diablaka 1650. J: g. Czerniawa Sucha 1000; przeł. Jałowiecka 1017; H. Kamińskiego 1118; g. Mędralowa 1170; przys. Opaczne 900 ; g. Westka 930.

T. viridescens (Schrad.) Coppins \& P. James $[=$ Lecidea viridescens (Schrad.) Ach.] - Butwiejące pniaki, głównie w naturalnych lasach; miejsca cieniste; rg. d. 18 stan. WR: pot. Urwisko 730; pot. Pętkówka 740; Las Ku Zimnej Wodzie 800; pol. Majów 805; rez. Śrubita 810; g. Wiertalówka 980; las Ku Kołysce 1000. P: Potok Jakubowski 700; pot. Romanka 750; pot. Sopotnia Wielka 850; pot. Kościelec 870; pol. Lachowe Młaki 910; g. Okrągła 940; pol. Latynka 1000. J: pot. Głucha 650; g. Jałowiec 1000; pot. Magurka 750; Roztoki 800.

Tremolecia atrata (Ach.) Hertel [= Lecidea dicksonii auct.] - Bezwapienne piaskowce (skały, piargi, głazy); miejsca suche i widne; kos.

17 stan. BG: Kościółki 1400, 1510, 1580; Akademicka Perć 1610, 1660, 1670; m. Kościółkami a Diablakiem 1625; Diablak 1660, 1675, 1710, 1725; S stok Diablaka 1600, 1610, 1660.

Tuckermanopsis chlorophylla (Willd. in Humb.) Hale [= Cetraria chlorophylla (Willd. in Humb.) Vain.] - Kora oraz gałęzie drzew iglastych, rzadziej liściastych; rg. d., rg. g., kos.

19 stan. WR: Śliwkówka 730; g. Wiertalówka 1065; g. Będoszka Wielka 1110; H. Muńczoł 1115. P: pot. Stara Piła 780; g. Magurka k. g. Trzy Kopce 1080; Śmierdzący Potok 1090; rez. Rysianka 1120, 1180; m. halami Lipowską i Bieguńską 1280; g. Szczawinka 1315; g. Palenica 1320; g. Pilsko 1400. J: dol. Koszarawy 800 ; H. Kubalkowa 1000.

\section{T. sepincola (Ehrh.) Hale [= Cetraria sepincola (Ehrh.) Ach.] - Gałęzie} kosodrzewiny; kos.

5 stan. P: g. Pilsko 1450, 1460, 1490, 1500. BG: Kościółki 1580.

Umbilicaria cylindrica (L.) Delise ex Duby - Bezwapienne piaskowce (skałki, piargi, głazy i kamienie); miejsca suche i widne; rg. d., rg. g., kos.

65 stan. WR: g. Zabawa 800; g. Rachowiec 850; pol. Raztoki 750; g. Beskid Wrzeszcz 860; Oźna 880, 930; pol. Kołyska 1010; g. Praszywka Duża 1030; g. Bugaj 1050. P: Sopotnia Wielka 735; Kolonia 750; Tokarnia 780; H. Durajka 835; Graberki 900; pol. Alacowa 925; g. Prusów 1000; g. Malarka 1015; pol. Krawcula 1035; H. Bieguńska 1200; H. Lipowska 1200, 1250; g. Pilsko 1385, 1400, 1420, 1445, 1450, 1535. BG: Cyl 1485, 1515; Sokolica 1370; Suchy Potok 1365; Kępa 1520; Główniak 1570; Kościółki 1500, 1510, 1580, 1600; Akademicka Perć 1525, 1555, 1590, 1610, 1670; m. Kościółkami a przeł. Brona 1625, 1650, 1660, 1675, 1680, 1700, 1710; S stoki Diablaka 1580, 1600, 1610, 1660. J: g. Surzyny 670; Figury 700; g. Kamienna 740; g. Surzynówka 800; poniżej g. Przyborówka 890; g. Magurka 870; g. Biały Wierch 1040. 
U. deusta (L.) Baumg. - Bezwapienne piaskowce (skałki, głazy w trawiastych murawach); miejsca nieco wilgotniejsze; pg., rg. d., rg. g., kos.

16 stan. WR: g. Bugaj 1050. P: H. Malarka 1000; H. Bieguńska 1160; g. Rysianka 1310. BG: Akademicka Perć 1410, 1670; Diablak 1675, 1680, 1710, 1725; S stoki Diablaka 1580, 1600, 1660. J: g. Czerniańska 500; g. Kamienna 620; g. Magurka 870.

U. polyphylla (L.) Baumg. - Bezwapienne kamienie piaskowcowe; miejsca widne i suche; rg. d.

1 stan. P: g Prusów 965.

Usnea filipendula Stirt. [ = U. dasypoga (Ach.) Shirley] - Kora i gałęzie starych drzew iglastych (świerki, jodły, modrzewie, kosodrzewina) oraz liściastych; rg. d., rg. g., kos.

53 stan. WR: pot. Czadeczka 560; rez. Butorza 660; dol. Radeckiego 700; H. Muńczoł 1100; pot. Plaskurówka 710; leśniczówka Pod Raczą 715; g. Będoszka Wielka 1100; pot. Racza 755; dol. Urwiska 700; rez. Śrubita 780. P: leśniczówka Janikówka 415; pot. Romanka 725; Żabnicka Rzeka 600; g. Romanka 1350, 1360; H. Wieprzska 1130, 1175; dol. W Ciemnym 900; g. Prusów 1000; las poniżej H. Mędralowej 1280; g. Szczawinka 1315; g. Rysianka 1180, 1300; rez. Rysianka 1130, 1150; H. Bacmańska 1125; H. Bieguńska 1150; g. Jaworzyna k. Pilska 1025; g. Pilsko 1490; g. Lipowska 1310; dol. Bystrej 875; g. Magurka k. Trzech Kopców 1035, 1080; m. pot. Śmierdzący i Zająców 1090; Zająców Potok 910; dol. Nickuliny 670; Złotnice 925; pot. Z Gawłowskiego 710; pot. Połom 790; Bura Polana 665; Placówka 710; dol. Stara Piła 780, 900; pot. Kościelec 760; g. Okrągła 940; dol. Straceńca 695, 775, 870; pol. Plekońka 960; m. pol. Plekońka i Krawcula 1000. BG: las poniżej Akademickiej Perci 1225. J: H. Kamińskiego 1100 .

U. florida (L.) Web. ex Wigg. - Według MOTYKI (1936) rośnie na Babiej Górze; obecnie nie potwierdzona.

U. glauca Mot. - Stare drzewa liściaste, rzadziej iglaste (jodły); rg. d.

6 stan. WR: pol. Juroszkowa 850; H. Muńczoł 1115. P: Sułki 665; Placówka 710; pot. Straceniec 775; H. Bieguńska 1150.

U. hirta (L.) Web. ex Wigg. - Kora drzew iglastych, liściastych oraz martwe drewno (szopy); rg. d.

8 stan. WR: pot. Czadeczka 560; rez. Butorza 620; Przegibek 1020. P: Bura Polana 665; pot. Z Gawłowskiego 675. J: dol. Koszarawy 850; przys. Opaczne 850; H. Kubalkowa 1000.

U. longissima Ach. - Według MOTYKI (1936) rośnie na Lipowskiej i Babiej Górze; obecnie już nie potwierdzona.

U. scrobiculata Mot. - Według MOTYKI (1936) rośnie na Babiej Górze; obecnie nie potwierdzona.

U. subfloridana Stirt. [ = U. comosa (L.) Vain.] - Kora i gałęzie drzew liściastych oraz iglastych; rg. d., rg. g.

21 stan. WR: pot. Racza 575; las Solisko 650; Raztoki 700; pot. Urwisko 700. P: Żabnicka Rzeka 600; pot. Straceniec 695, 775, 870; pot. Stara Piła 800; pol. Juraszkowa 1000; H. Jodłowcowa 1100, 1200; H. Bacmańska 1139; rez. Rysianka 1130, 1150, 1180; H. Pawlusia 1170; H. Łyśniowska 1190; pol. Między Młaki 1200. J: H. Kamińskiego 1100; g. Mędralowa 1150.

Verrucaria aethioboloides Zsch. - Bezwapienne kamienie piaskowcowe, zanurzone w czystej wodzie potoków górskich, przeważnie blisko źródeł; rg. d. 1 stan. P: m. halami Miziową i Szczawiną 1160.

V. anziana Garov. [= Polyblastia anziana (Garov.) Serv.] - Bezwapienne głazy i kamienie piaskowcowe okresowo zalewane wodą w łożyskach potoków górskich, rzadziej w źródłach, zwykle wystające ponad lustro wodne; rg. d. 
11 stan. WR: pot. Sucha Nieledwianka 520; Karchówka 565; Soblówka 670; pot. Urwisko 700. P: pot. Bystra 510; pot. Studziański 635; H. Wieprzska 1060. J: dol. Czernej 500; dol. Dejówki 560; dol. Grzechynki 575; dol. Wilkówki 470.

V. aquatilis Mudd - Bezwapienne kamienie piaskowcowe zanurzone w czystej wodzie potoków górskich oraz źródeł; pg., rg. d., rg. g.

13 stan. WR: pot. Plaskurówka 735; pot. Danielka 755; Szczotka 880. P: pot. Fułatów 460; pot. Sopotnia Wielka 650; dol. W Kotarnicy 830; pot. Kajdasówka 860; H. Mędralowa 1320. J: dol. Grzechynki 450; m. g. Janoszka a g. Kiczora 560; dol. Magurki 830; Roztoki 700; poniżej Pytel 550.

V. atroviridis Serv. ex J. Nowak \& Tobol. - Kamienie piaskowcowe zanurzone w czystej wodzie potoków górskich; rg. d.

1 stan. J: Roztoki 700.

V. calciseda DC. [= Amphoridium calcisedum (DC.) Serv. $]$ - Skałki i głazy wapienne; pg.

1 stan. P: Sporysz 420.

V. confluens Massal. - Wapniste piaskowce (skałki oraz głazy wśród traw); pg., rg. d.

2 stan. P: Sopotnia Mała 525; g. Abrahamów 810.

V. deminuta Serv. [= Amphoridium deminutum (Serv.) Serv.] - Nasłonecznione skałki piaskowcowe o dużej zawartości węglanu wapnia i glaukonitu; pg. 1 stan. J: m. Grzechynią a Skupniówką 700.

$\boldsymbol{V}$. denudata Zsch. - Bezwapienne piaskowce (kamienie i głazy) zanurzone stale lub okresowo w czystej wodzie potoków górskich i źródeł, nierzadko na progach skalnych burzących wodę; pg., rg. d., rg. g., kos.

10 stan. WR: pot. Sucha Nieledwianka 520; Myto 690. P: dol. W Kotarnicy 735; pot. Kajdasówka 860; dol. Z Wideł 1080; pot. Glinna 1150; g. Lipowska 1250; Pilsko (H. Słowikowa) 1500. J: Roztoki 700; poniżej Podjałowca 850 .

V. cf. dolosa Hepp - Bezwapienne lub lekko wapniste piaskowce na nieużytkach; pg.

1 stan. P: Przyłęków 550.

V. cf. funckiana Serv. - Zaprawa murarska na murach oporowych wzdłuż potoków górskich; miejsca suche; rg. d.

2 stan. WR: pot. Rycerka 600. J: dol. Dejówki 520.

V. funckii (Spreng. in Funck) A. Zahlbr. $[=V$. silicea Serv. $]$ - Bezwapienne kamienie piaskowcowe okresowo zalewane czystą wodą w potokach górskich i w źródłach; rg. d., rg. g., kos.

5 stan. WR: pot. Radecki 700. P: pot. Sopotnia Wielka 650; Szeroki Kamieniec 1100; g. Lipowska 1250; g. Pilsko (H. Słowikowa) 1450.

V. fuscella (Turn.) Winch - Wapniste piaskowce (skałki) na powierzchniach pionowych; rg. d.

1 stan. P: g. Skałka 1195.

V. cf. guestphalica Serv. - Bezwapienne głazy i kamienie piaskowcowe okresowo zalewane wodą w łożyskach potoków górskich i rzek, zwykle wystające ponad wodę; pg., rg. d.

13 stan. WR: pot. Sucha Nieledwianka 520; Myto 690; pot. Urwisko 700; pot. Stasiowa 700. P: Za Kopcem 600; pot. Sopotnia Wielka 650; Kotrysia Polana 735. J: dol. Zasepnicy 440; Janiczki 500; dol. Dejówki 520; dol. Grzechynki 540; dol. Czernej 540; poniżej Bartoszek 580. 
$\boldsymbol{V}$. laevata auct. - Bezwapienne kamienie piaskowcowe, okresowo zalewane czystą bądź lekko mulistą wodą w potokach górskich, rzadziej w źródłach; pg. rg. d.

17 stan. WR: pot. Czadeczka 500; dol. Leżaje 750; Szczotka 880. P: pot. Fułatów 460; pot. Studziański 635. J: dol. Czernej 500; dol. Głucha 600; dol. Grzechynki 450; dol. Wilkówki 470, 475; Janiczki 500 ; przeł. Klekociny 890 ; pot. Kolędówka 650 ; Kudzie 575; Opaczne 925; poniżej Podjałowca 850; Roztoki 700.

V. muralis Ach. - Wapniste piaskowce, głównie kamyki leżące na nieużytkach; rg. d.

1 stan. WR: Podścigłów 770.

V. polygonia Koerb. [= Amphoridium polygonium (Koerb.) Serv.] - Skałki i głazy wapienne; miejsca suche i widne; pg.

1 stan. P: Sporysz 420.

V. rheithrophila Zsch. $[=V$. Kernstockii Zsch. $]$ - Kamienie piaskowcowe zanurzone w czystej wodzie źródeł i potoków górskich; rg. d.

1 stan. J: poniżej Podjałowca 850.

V. rupestris Schrad. - Nasłonecznione skałki piaskowcowe z dużą zawartością węglanu wapnia; rd. d.

1 stan. J: Matusy 650.

V. sagedioides Serv. - Bezwapienne kamienie piaskowcowe zanurzone w wodzie potoków górskich; rg. d.

1 stan. P: pol. Bartek 1140.

V. subhydrela Serv. - Bezwapienne kamienie piaskowcowe zanurzone w czystej lub lekko mulistej wodzie potoków górskich oraz źródeł; pg., rg. d.

5 stan. WR: Szczotka 880. P: pot. Kajdasówka 860. J: Kolędówka 780; Opaczne 925; Janiczki 500.

V. sublobulata Eitn. ex Serv. - Bezwapienne kamienie piaskowcowe zanurzone stale lub okresowo w czystej lub lekko mulistej wodzie potoków górskich; rg. d.

4 stan. WR: pot. Danielka 755. P: pot. Fułatów 460. J: dol. Grzechynki 575; Kudzie 575.

V. submauroides Zsch. - Bezwapienne kamienie piaskowcowe okresowo zwilżane wodą w łożyskach potoków górskich, rzadziej zanurzone w źródłach; rg. d.

2 stan. P: H. Wieprzska 1040. J: H. Kamińskiego 1090.

Vulpicida pinastri (Scop.) J.-E. Mattsson \& M. J. Lai [ = Cetraria pinastri (Scop.) Gray] - Kora drzew iglastych, rzadziej liściastych, u nasady pni i przy korzeniach, także na gałęziach kosodrzewiny i jałowców, na pniakach i krzewinkach borówek; rg. d., rg. g., kos.

105 stan. WR: pot. Czadeczka 545; g. Kiczorka 700; pol. Babczonka 620; g. Sołowy Wierch 840; m. Krutakami i Tarlicznem 635; g. Trojaki 615; rez. Butorza 620; g. Rachowiec 800; g. Kokocz 730; dol. Danielki 720, 725; Stawiska 770; g. Jaworzyna 885; pol. Juroszkowa 850; H. Muńczoł 1100, 1125; Rycerki 640, 645; pot. Plaskurówka 710; Żebrakówka 800; pot. Pętkówka 715; pol. Raztoki 875; Smereków Wielki 800; pol. Skrzadnita 1105; H. Przysłop 950; g. Mała Racza 815; g. Wielka Racza 1210; g. Rycerzowa Wielka 1195; pot. Urwisko 705, 780; m. g. Wielka Racza i g. Upłaz 1050; pol. Glowa 815 . P: pot. Bystra 585; las Tajch 750; g. Romanka 1360, 1365; pot. Romanka 725; H. Wieprzska 1060; dol. W Ciemnym 900; pol. Buczynka 835; g. Prusów 1000; Milówki 700; Sikorczany Potok 700; pot. Syndzielny 780; g. Rysianka 1300, 1320; g. Pilsko 1350, 1360, 1400, 1450, 
1490, 1500; g. Palenica 1340; g. Szczawinka 1315; H. Miziowa 1220; H. Cukiernicza Wyżnia 860; Turniczka 1380; g. Boraczy Wierch 1160; H. Bacmańska 1125; H. Bieguńska 1150; las powyżej H. Mędralowej 1340; H. Lipowska 1100; g. Jaworzyna k. Pilska 1025; pol. Sucha Góra 940; g. Magurka k. Trzech Kopców 1080; m. potokami Śmierdzącym i Zająców 1090; Zająców Potok 975; Śmierdzący Potok 760; pot. Z Gawłowskiego 710; Potok Jakubowski 680; g. Bucioryska 760; pot. Kościelec 760; Złatna 600; g. Okrągła 940, 1000; Polany Pod Soblówką 900; pol. Plekońka 960; m. polanami Plekońka i Krawcula 1000. BG: H. Czarna 1200; Cyl 1485; Sokolica 1370; przeł. Brona 1410; m. Kościółkami a przeł. Brona 1450; H. Kralowa 1255; pot. Kiczorka 1395. J: dol. Grzechynki 550; dol. Czernej 580; pot. Stracony Potok 600; Kępy 600; g. Skupniówka 650; pot. Kolędowy Potok 650; Roztoki 650, 700; Drwalówka 690; g. Kamienna 720; dol. Koszarawy 800; dol. Magurki 830; las Czerniawa 940; H. Kubalkowa 1000; g. Czerniawa Sucha 1030; H. Kamińskiego 1050.

Xanthoparmelia conspersa (Ehrh. ex Ach.) Hale $[=$ Parmelia conspersa (Ehrh. ex Ach.) Ach.] - Bezwapienne piaskowce (kamienie na halach, polanach i nieużytkach, stosy kamieni, gołoborza); miejsca suche i widne; pg., rg. d.

16 stan. WR: m. Rajczą a Rycerką 500; Głębokie 610; g. Łysica 550; g. Rycerzowa 1170. P: g. Grapa Żar 430; Skałka 600; Kolonia 750; g. Krawców Wierch 1066. J: dol. Zasepnicy 440; dol. Grzechynki 450; g. Czerniańska 500; g. Gawronowa 580; dol. Głucha 580; g. Skupniówka 600; Roztoki 610; Głuchaczki 730.

Xanthoria candelaria (L.) Th. Fr. - Kora samotnych drzew liściastych lub iglastych, głównie u nasady pni; pg., rg. d.

6 stan. WR: Rycerka 500; Kasperki 670; Ujsoły 520; Podścigłów 700. P: Sopotnia Wielka 620. J: Grzechynia 400.

X. elegans (Link) Th. Fr. - Podłoże betonowe; miejsca suche i widne; pg., kos. 3 stan. WR: Rycerka 510; Zwardoń; 650. BG: ruiny schroniska pod Diablakiem 1600.

$X$. fallax (Hepp) Arnold - Kora drzew przydrożnych; pg., rg. d.

15 stan. WR: Rajcza 500; Tarliczne 590; Rycerka Dolna 515, 525. P: Przyłęków 745; Cięcina 445; Krzyżowa 550; Korbielów Dolny 550; Kamienna 650. J: dol. Zasepnicy 440; Koszarawa 590; Wełcza 630, 790; Spikówka 650; g. Wełczon 800.

X. parietina (L.) Th. Fr. - Kora drzew liściastych, głównie przydrożnych, rzadko na podłożu skalnym i betonowym; gatunek jeszcze dość częsty, ale wyraźnie ustępujący; pg., rg. d.

47 stan. WR: Sucha Nieledwianka 485; Pietraszyna 840; Nieledwia 470, 565; Tarliczne 590; Szpaki 570; Kiczora 610; Karchówka 565; pot. Z Głębokiego 520; pol. Butorowe Grapy 540; Ujsoły 530; Rajcza 500; pot. Rycerka 580; przys. Szczotka 890, 900; g. Jaworzyna 900; Podścigłów 700; Pętkówka 650; Słonkówka 625; Kolonia 670; leśniczówka Pod Raczą 715. P: g. Grojec 610; Sporysz 425; Jeleśnia 415; Trzebinia 425; Juszczyna 430, 450; g. Kotarnica 1000; m. Ciścem a Milówką 650; Żabnicka Rzeka 600; Złatna 600, 610; Kotrysia Polana 730. BG: Polichówka 635. J: Głuszki 400; Koszarawa 590; Wełcza 630; Kiecka 700; Janiki 780 .

$X$. polycarpa (Hoffm.) Th. Fr. ex Rieber - Kora drzew liściastych lub martwe drewno; pg., rg. d.

11 stan. WR: Nieledwia 490; Zapasieki 660; Laliki Wielkie 700; Rycerki 620; g. Jaworzyna 885; Przegibek 1020. J: Głuszki 400; Koszarawa 590; Wełcza 630; Kiecka 700; Janiki 780.

X. ulophyllodes Rds. - Kora drzew liściastych, głównie przydrożnych, np. jesiony; gatunek zapewne przeoczony; rg. d.

1 stan. WR: Słonkówka 625.

Xylographa parallela (Ach.: Fr.) Behlen \& Desberg $[=X$. abietina (Pers.) A. Zahlbr] - Stare, butwiejące drewno (pniaki, kłody okorowane, parkany, belki); miejsca cieniste i nieco wilgotne oraz widne i suche; rg. d., rg. g. 
53 stan. WR: g. Kiczorka 725; pot. Stasiowa 650; Rycerki 645; Soblówka 670; pot. Danielka 700; pot. Smerekówka Wielka 700; pot. Plaskurówka 710; Oźna 870; g. Jaworzyna 930; H. Przysłop 940; g. Plaskierówka 1000; g. Kikula 1100; g. Kotarz 1110; H. Muńczoł 1125. P: pot. Głęboki 595; Potok Jakubowski 645; Sułki 660; pot. Z Gawłowskiego 720; dol. W Kotarnicy 735; pot. Stara Piła 740, 780; dol. Do Jodłowcowej 800; g. Długi Groń 850; pol. Buczynka 860; dol. W Ciemnym 900; g. Wilczy Groń 940; pol. Krawcula 1035; H. Motykowa 1050; H. Szczawina 1060; m. potokami Śmierdzący i Zająców 1055; g. Romanka 1075; H. Cebulowa 1225; H. Miziowa 1220; g. Lipowska 1260; g. Skałka 1140; H. Bieguńska 1150; g. Rysianka 1320. J: dol. Bystrej 700; dol. Czernej 580; Figury 870; pot. Głucha 700; g. Jałowiec 1030; przeł. Klekociny 890; Kolędówka 810; H. Kubalkowa 1000; pol. Magurka 850; poniżej g. Mędralowa 850; Nowy Świat 570; pot. Opaczny 650; powyżej Pindelówki 1050; g. Surmiaków Groń 760; g. Urwisko 660; g. Witkówka 700. 